
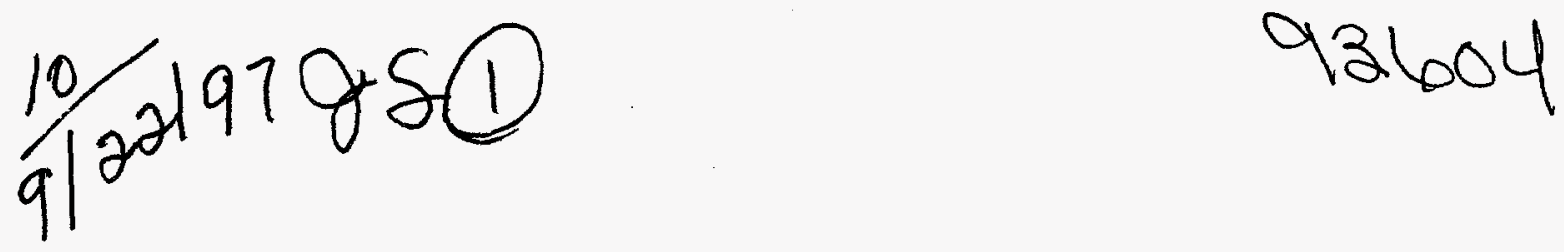

\title{
Assessing Environmental Risk of the Retired Filter Bed Area, Battelle West Jefferson
}

by S.F. Miller, M.D. Thompson, M.A. Glennon, B.E. Davies, M.A. Benson,

C.A. Padar, L.D. McGinnis, and J. Paulson*

Center for Environmental Restoration Systems, Energy Systems Division, Argonne National Laboratory, 9700 South Cass Avenue, Argonne, Illinois 60439

\section{DISCLAIMER}

This report was prepared as an account of work sponsored by an agency of the United States Government. Neither the United States Government nor any agency thereof, nor any of their empleyees, makes any warranty, express or implied, or assumes any legal liability or responsibility for the accuracy, completeness, or usefulness of any information, apparatus, product, or process disclosed, or represents that its use would not infringe privately owned rights. Reference herein to any specific commercial product, process, or service by trade name, trademark, manufacturer, or otherwise does not necessarily constitute or imply its endorsement, recommendation, of favoring by the United States Government or any agency thereof. The views and opinions of authors expressed herein do not necessarily state or reflect those of the United States Government or any agency thereof.

April 1997

Work sponsored by United States Department of Energy,

Columbus Environmental Management Project and Chicago Operations Office

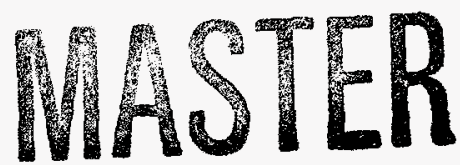

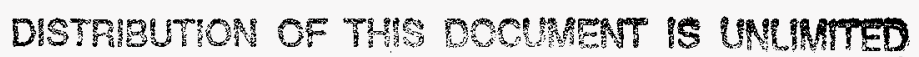

"Paulson is affiliated with the United States Department of Energy, Chicago Operations Office.

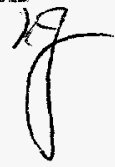


बत्

This report is printed on recycled paper. 


\section{DISCLAMMER}

Portions of this document may be illegible in electronic image products. Images are produced from the best available original document. 


\section{Contents}

Abstract.

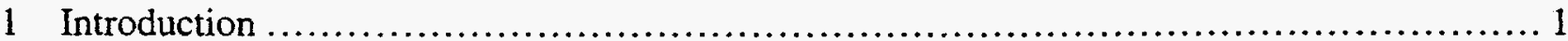

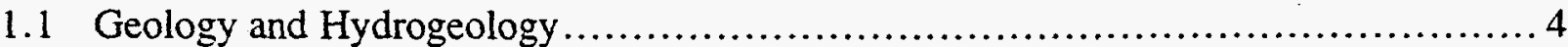

1.1 .1 General Overview........................................................... 4

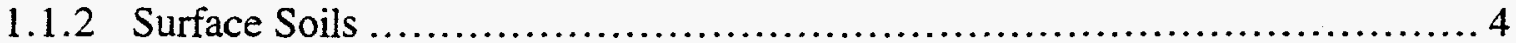

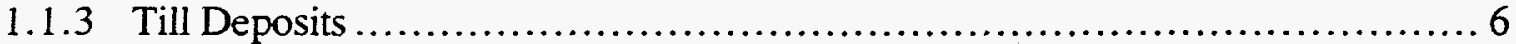

1.1.4 Outwash and Alluvium Deposits.......................................... 12

1.1 .5 Lacustrine Deposits........................................................ 15

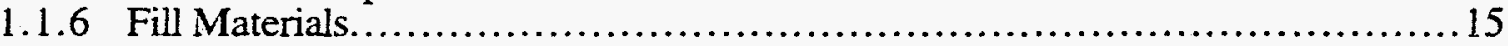

1.1.7 Bedrock ..................................................................

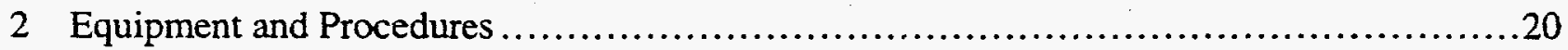

2.1 Electromagnetic, Resistivity, and Magnetic Measurements..........................20

2.1.1 Electrical Conductivity Mapping with the EM-31 and EM-34 $\ldots \ldots \ldots \ldots \ldots \ldots \ldots . \ldots \ldots$

2.1.2 Vertical Electrical Sounding ................................................ 20

2.1.3 Magnetic Gradiometer and Cable Locator....................................

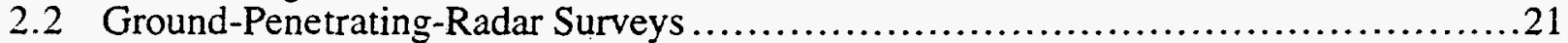

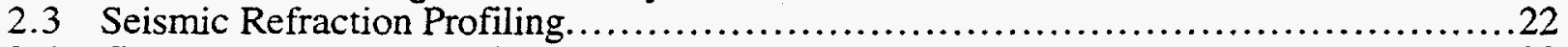

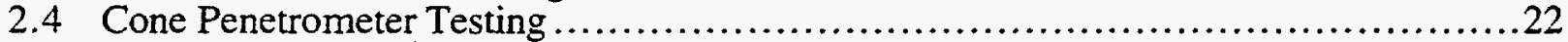

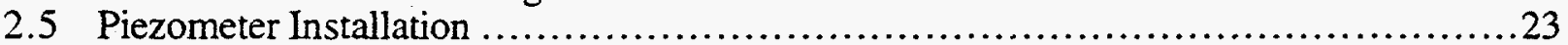

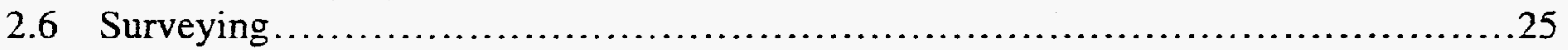

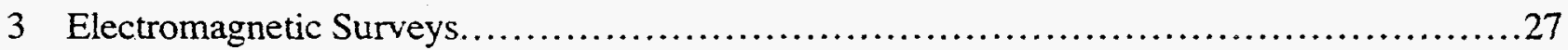

3.1 EM-31 Mapping................................................................27

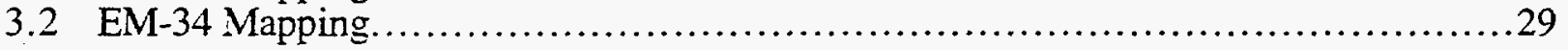

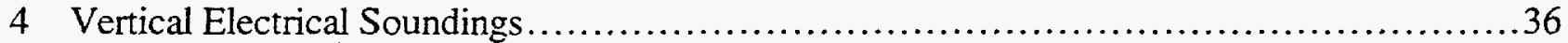

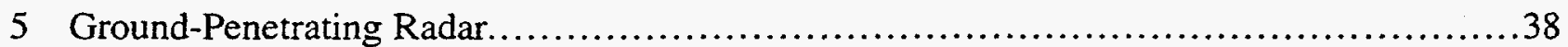

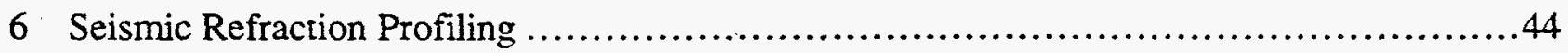

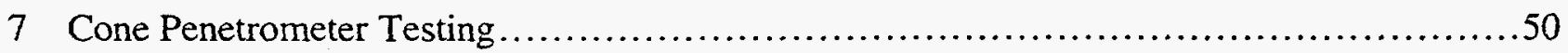

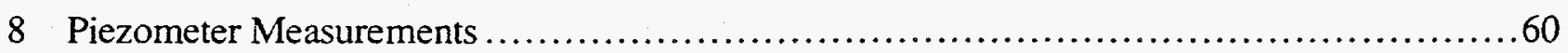

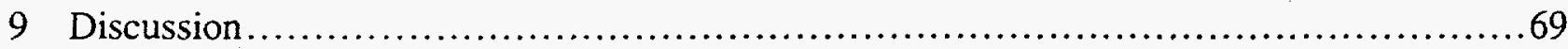

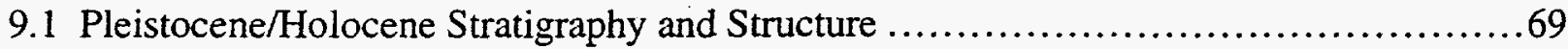

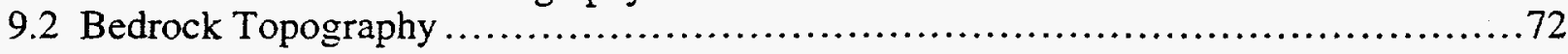

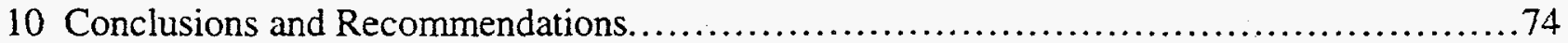

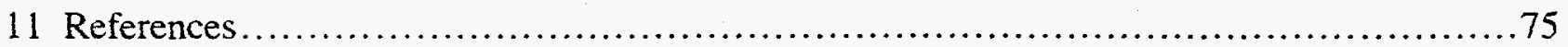




\section{Contents (Cont.)}

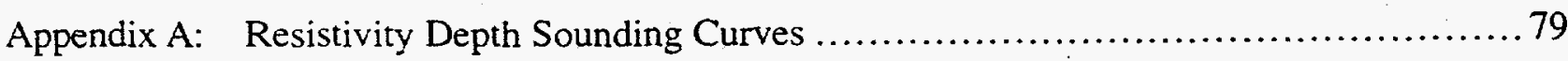

Appendix B: Coordinates of Ground-Penetrating-Radar Profiles at Battelle West Jefferson

Appendix C: CPT Soundings ................................................... 103

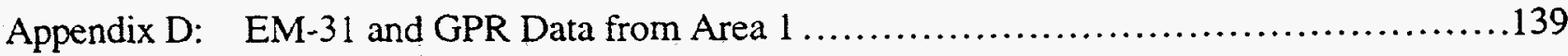

Appendix E: Analytical Chemistry Results at Battelle West Jefferson .....................145

\section{Tables}

1 Comparison of Particle Size Distributions in Lacustrine Clay at

Battelle West Jefferson Site

2 Revised Elevation Data for 2-in. Groundwater Monitoring Wells at the BWJ Retired Filter Bed Area.

3 CPT Locations and Elevations at West Jefferson Filter Bed Area........................50

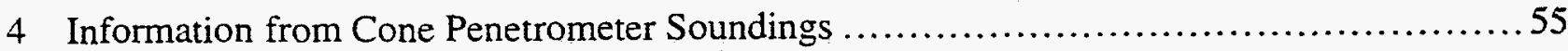

5 Temporary Piezometer Locations............................................. 60

6 Groundwater Elevation Data for Six Well Points in the Battelle West Jefferson Retired Filter Bed Area

7 Groundwater Elevation Data at the Battelle West Jefferson Retired Filter Bed Area 61

8 Anomalies Detected by Electromagnetic Instruments 69

\section{Figures}

1 General Location Map of the Battelle West Jefferson Site. .2

2 Detailed Site Map of the Battelle West Jefferson Site

3 Generalized Soil Map of the Battelle West Jefferson Site .5 


\section{Figures (Cont.)}

4 Diagram Showing the Quaternary Surficial Deposits and Silurian-Devonian Formations in Jefferson Township, Madison County, Ohio ............................. 7

5 Structure Contour Map on the Top of Gray Till at Battelle West Jefferson Site ............. 8

6 Location of Deep Borings at Battelle West Jefferson Site ............................. 9

7a Geological Descriptions for Deep Borings/Wells at Battelle West Jefferson, Right Panel

$7 \mathrm{~b}$ Geological Descriptions for Deep Bores/Wells at Battelle West Jefferson, Left Panel.

8 Soil Borings in Area 1 along the North Bank of Silver Creek ........................... 13

9 Geologic Profile of Retired Filter Bed Area at Battelle West Jefferson Site ................. 14

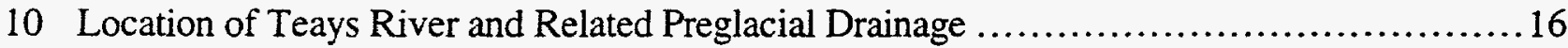

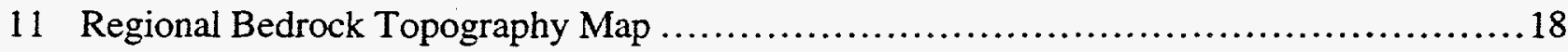

12 Schematic Drawing of Piezometer Construction........................................24

13 Map of Terrain Conductivity Anomalies Measured by the EM-31 at Battelle West Jefferson............................................................. 28

14 Map of Terrain Conductivity Anomalies Measured by the EM-31 in the North Subarea

15 Map of Terrain Conductivity Anomalies Measured by the EM-31 in the Southeast Subarea.

16 Map of Terrain Conductivity Anomalies Measured by the EM-31 in a

Portion of the Southeast Subarea

17 Map of In-Phase Conductivity Anomalies Measured by the EM-31

at Battelle West Jefferson.

18 Map of Terrain Conductivity Anomalies Measured by the EM-34 at Battelle West Jefferson.

19 Map of Locations of Resistivity Soundings Conducted at Battelle West Jefferson 37 


\section{Figures (Cont.)}

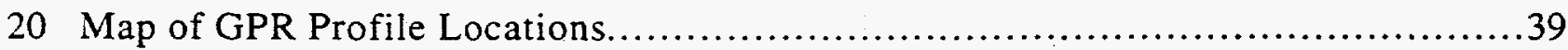

21 GPR Profile \#4 across Retired Filter Beds ............................................40

22 North-South GPR Profile (\#2) along Geophysical Grid Coordinate 870E.................42

23 East-West GPR Profile (\#16) along Geophysical Grid Coordinate 500N.................43

24 Map Showing Locations of Seismic Refraction Profiles, CPT and Piezometer Sites ........45

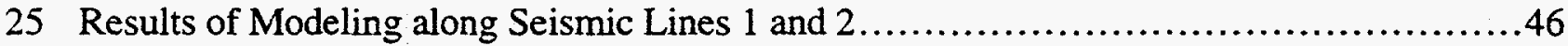

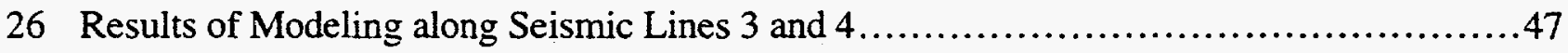

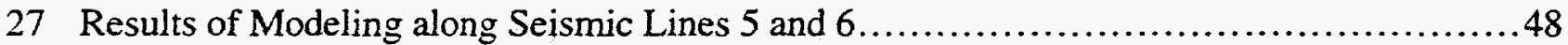

28 Comparison of Geologic Log from Borehole R144 and CPT17 Electronic Log.............52

29 Structural Contour Map of the Top of the Glacial Till..................................54

30 Correlation of CPT Electric Log Data from CPT01 and CPT02 ......................56

31 Correlation of CPT Electric Log Data from CPT03, CPT05, and CPT06.................57

32a Interpreted N-S Profile of CPT Borings, Left Panel .................................58

32b Interpreted N-S Profile of CPT Borings, Right Panel ...............................59

33 Hydrographs at Battelle West Jefferson Retired Filter Bed Area ........................62

34 Intrepreted Generalized Geology at Piezometer Locations............................6 63

35 Potentiometric Surface Map for November 22, 1995, at Battelle West Jefferson ...........65

36 Potentiometric Surface Map for June 6, 1995, at Battelle West Jefferson..................66

37 Hydrogeologic Profile A-A' at Battelle West Jefferson .................................67

38 Map of Terrain Conductivities Measured by the EM-34, Overlayed with

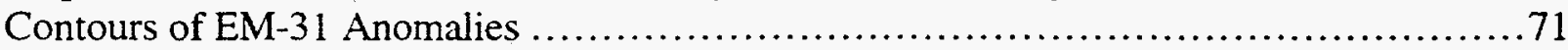

39 Map of Bedrock Elevations Determined from Seismic Modeling ........................73 


\title{
ASSESSING ENVIRONMENTAL RISK OF THE RETIRED FILTER BED AREA, BATTELLE WEST JEFFERSON
}

\author{
by \\ S.F. Miller, M.D. Thompson, M.A. Glennon, \\ B.E. Davies, M.A. Benson, C.A. Padar, L.D. McGinnis, and J. Paulson
}

\begin{abstract}
Initial investigations conducted by the U.S. Department of Energy, Chicago Operations Office, and by Argonne National Laboratory used seismic refraction profiling, electrical resistivity depth sounding, conductivity profiling, magnetic gradiometry, and ground-penetrating radar to study environmental geophysics in the area of the Battelle West Jefferson site's radiologically contaminated retired filter beds. The investigators used a combination of nonintrusive technologies and innovative drilling techniques to assess environmental risk at the filter beds and to improve understanding of the geology of the Big Darby Creek floodplain. The geophysical investigation, which showed that the preferred groundwater pathway is associated with a laterally extensive deposit of silty sand to sand that is less than $12 \mathrm{ft}$ deep in the floodplain area, also guided the location of cone penetrometer test sites and piezometer installation. Cone penetrometer testing was useful for comparing continuous logging data with surface geophysical data in establishing correlations among unconsolidated materials.
\end{abstract}

\section{Introduction}

An environmental geophysics study was conducted at the radiologically contaminated retired filter beds at the Battelle West Jefferson (BWJ) site (Figure 1), in order to define the hydrogeologic framework, characterize potential contaminant pathways, identify possible leakage points in buried pipelines and drainage tile, and install piezometers.

The BWJ site includes a Nuclear Sciences Area (known as the JN site) and the radiologically contaminated retired filter beds that are located on the floodplain of the Big Darby Creek, designated as a National Scenic River (Figure 2). Battelle conducted a number of characterization efforts in 1989 and 1990 at the West Jefferson Site that involved an intrusive sampling approach for radiological contaminants. Although extensive work was done in some areas, a historical data review jointly conducted by the U.S. Department of Energy, Chicago Office (DOE/CH), and by the Battelle Project Office (DOE-BPO) and Battelle Columbus Laboratory Decommissioning Project (BCLDP) personnel in 1995 indicated that a need existed for understanding the environmental risk at the retired filter beds. It was also recognized that more thorough characterization of potential contaminant pathways along buried pipelines in the vicinity of the retired filter beds and of the risk to Big Darby Creek was needed. 


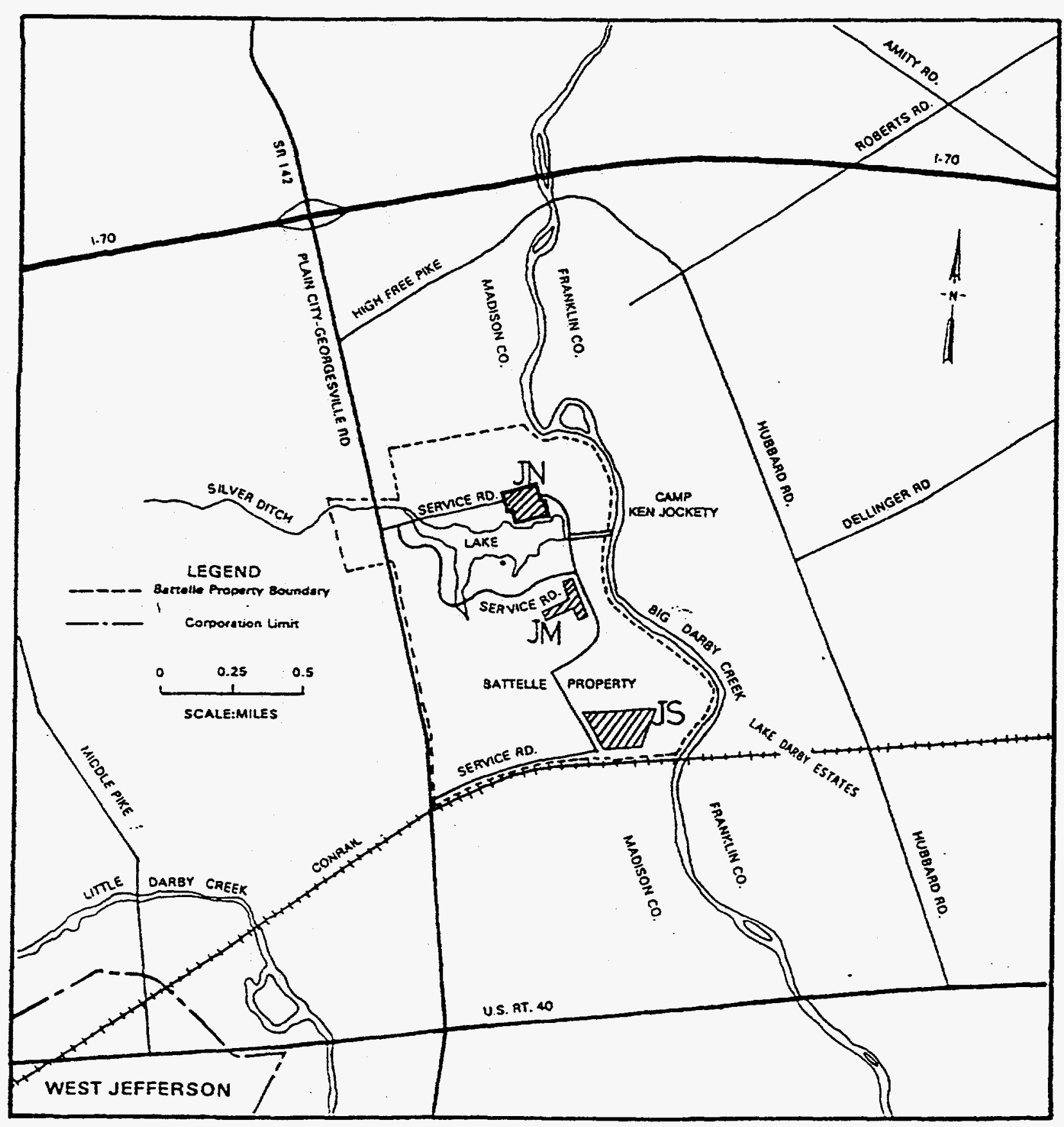

Figure 1. General Location Map of the Battelle West Jefferson Site 


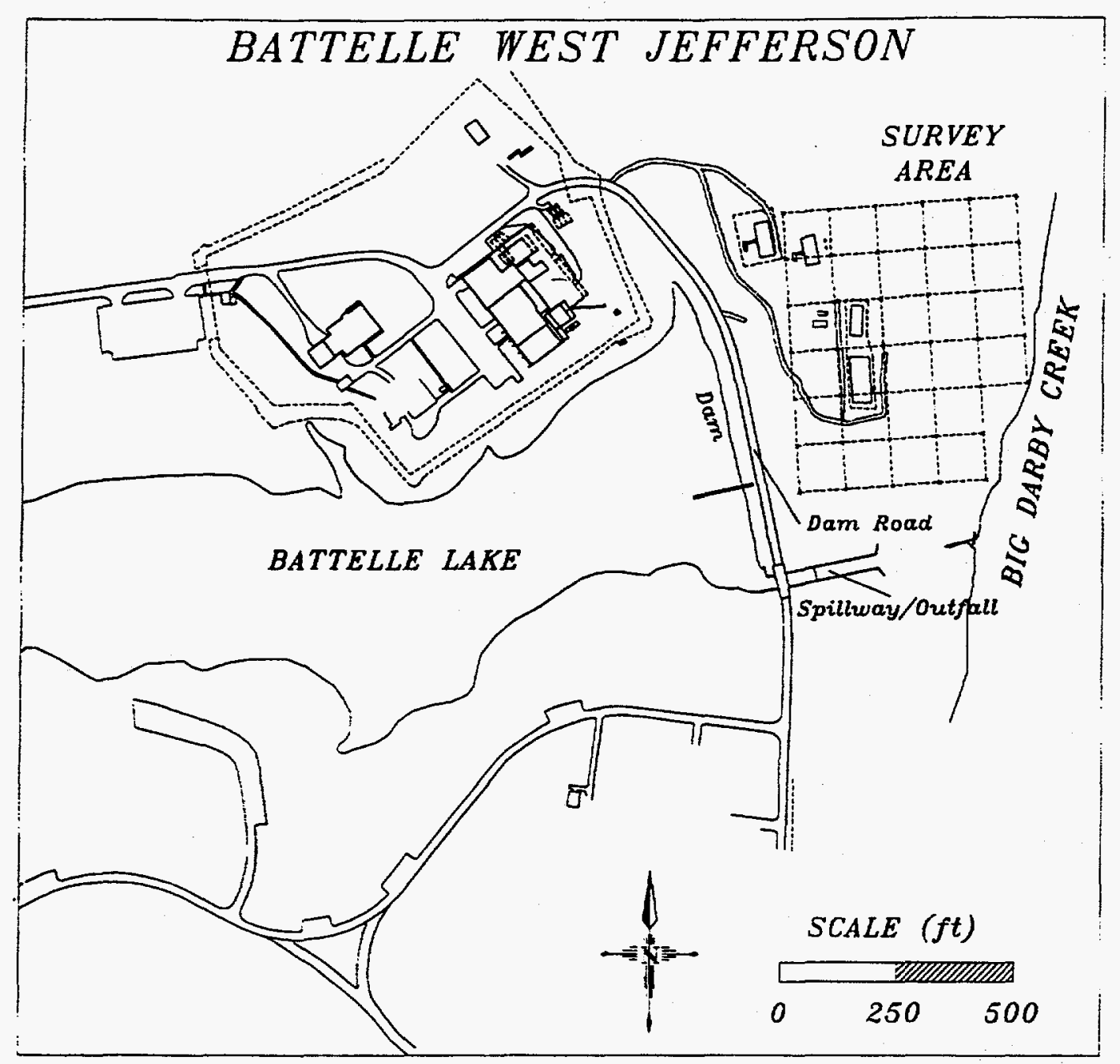

Figure 2. Detailed Site Map of the Battelle West Jefferson Site 
In the summer of 1995, after consultation with the Geosciences Group in the Center for Environmental Restoration Systems (CERS), Argonne National Laboratory (ANL), and with DOE/CH staff, DOE-BPO and BCLDP determined that a combination of nonintrusive technologies and innovative drilling techniques was needed to assess the environmental risk associated with radiological contamination at the retired filter beds. ANL/CERS had responsibility for technical management and for contractual arrangements for the cone penetrometer and piezometer installations.

Initial geophysical investigations were conducted by ANL/CERS and DOE/CH during the week of August 18, 1995. Geophysical technologies used at the BWJ site included seismic refraction profiling, electrical resistivity depth sounding, conductivity profiling with the EM-34 and the EM-31, magnetic gradiometry, and ground-penetrating radar (GPR). The geophysical investigation was used to establish the geologic framework in the floodplain area and to guide the placement of cone penetrometer testing (CPT) sites and piezometer locations. Seventeen CPT sites were investigated, six piezometers were installed, and additional GPR transects were completed during the week of September 19, 1995. A supplemental geophysical investigation was also conducted in Area 1, but this was limited to conductivity mapping with the EM-31 and to groundpenetrating radar. The Area 1 work was done in January 1996.

\subsection{Geology and Hydrogeology}

\subsubsection{General Overview}

The BWJ site is located in the Till Plains area of the Central Lowland Physiographic province. The site is underlain by unconsolidated deposits that range from 20 to $200 \mathrm{ft}$ in thickness. The unconsolidated materials underlying the uplands part of the site consist primarily of Pleistocene glacial drift and a relatively thin veneer of recent alluvial/fluvial sediments in the surface drainage areas. The glacial drift sediments, or till, consist of a heterogeneous and unsorted mixture of clay, silt, and sand-sized particles, with variable amounts of gravel. Outwash deposits are present as discontinuous lenses within the till in upland areas. In the floodplain of Big Darby Creek, including the retired filter bed area, outwash and fluvial (reworked outwash) sediments are present as a thin but continuous layer below the recent alluvium. Locally, beneath the glacial drift, remnants of lacustrine sediments are present in areas of abandoned Tertiary-age drainage.

\subsubsection{Surface Soils}

Four types of surface soils are present at the BWJ site: the Crosby-Lewisburg, LewisburgCelina, Miamian, and Medway soils (Couchot 1975; USDA 1981). The distribution of surficial soils is shown in Figure 3. The Crosby-Lewisburg soils develop on nearly level to gentle slopes, and the Lewis-Celina soils are situated on gentle slopes. Miamian soils formed in areas of gentle to steep sloping topography. Medway soils occupy floodplain areas and develop where the underlying substrate is alluvium. 


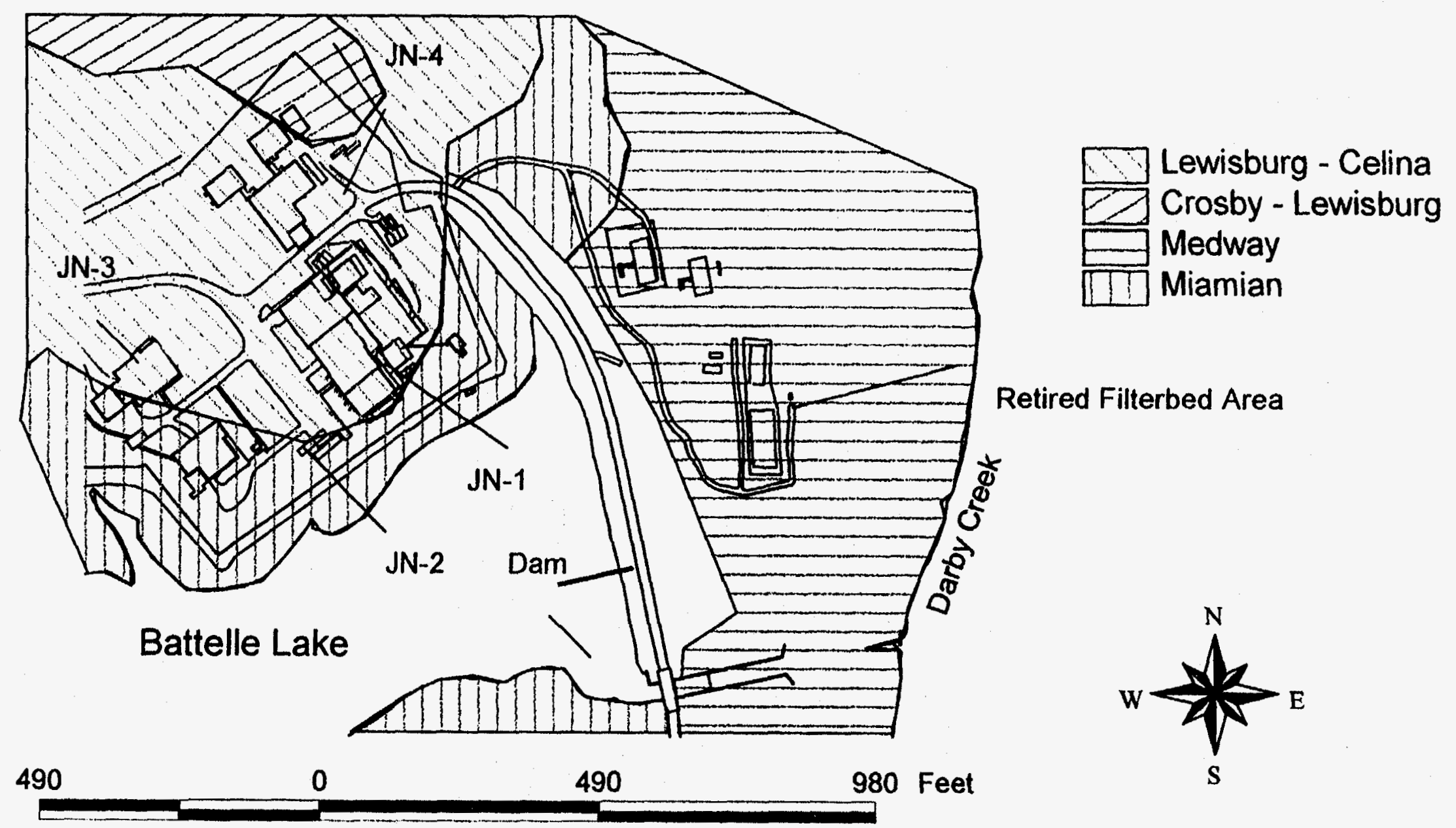

Figure 3. Generalized Soil Map of the Battelle West Jefferson Site 


\subsubsection{Till Deposits}

The glacial drift exposed at the surface in Madison County developed in response to multiple advances and retreats of the ice front during the Wisconsin age. Goldthwait (1969) reported that the drift was deposited from the Scioto Sublobe of the Erie Lobe of the Late Wisconsin glacier. The Scioto and Miami sublobes formed after the Wisconsin age glacier reached the highlands of Bellefontaine, Logan County, and then split into two ice masses that advanced along the respective river valleys (Goldthwait 1952). The BWJ site is geographically located in the area that Orton (1878) referred to as the "Darby Plains," an interfluve between Little Darby Creek and Big Darby Creek. The uppermost drift in the vicinity of the BWJ site involved Late Woodfordian ice deposits that were deposited between 18,000 and 14,000 years ago (Goldthwait and Van Horn 1993). Figure 4, which shows the general stratigraphy of the Quaternary and bedrock units, was compiled from available information for the Jefferson Township area. Although there is evidence that Illinoisan and multiple Wisconsin age glaciers advanced across western Ohio, only the near-surface till has been mapped.

Steiger and Holowaychuck (1971) reported that the Darby Till consists of $34 \%$ sand, $46 \%$ silt, and $21 \%$ clay, on the basis of grain size characterization data. We obtained comparable characteristics for the Darby Till underlying the Battelle site, with particle size fractions of $32 \%$ sand, $37 \%$ silt, and $27 \%$ clay (as mean values), through analysis of existing Battelle geotechnical reports (Burgess and Niple, Ltd. 1966; Jewel 1971). Battelle also conducted numerous soil bores as part of its environmental investigations during 1989-1990 in the north area of the site, also referred to as the "JN Area" and the "Nuclear Science Area." More than 168 environmental soil bores, largely concentrated in six areas, were conducted by Battelle at the BWJ during that period.

The previous Battelle environmental characterization effort involved extensive soil sampling activities; however, the use of the information for stratigraphic purposes is partially limited because liners were pervasively utilized. The geotechnical studies at the dam (Burgess and Niple, Ltd. 1966) and bores at the Hot Cell Area (Jewel 1971) provided the most detailed descriptions of the stratigraphy of the overburden. Most of the environmental bores and associated sampling activities focused on the characterization of the till deposits at upland locations where contamination was known or suspected near the Battelle JN research facilities. Some till and alluvial materials were also penetrated by earlier Battelle soil bores along the north bank of Silver Creek and at the Big Darby Floodplain, particularly at the retired filter bed area.

On the basis of the available Battelle subsurface information, a brown till in the JN area ranges from 11 to $12 \mathrm{ft}$ in thickness. Figure 5 shows the structure contours on the top of a gray till, according to the available Battelle soil bore information. The attitude of this interface appears to exhibit a northwest-to-southeast-trending depression or re-entrant between the dam and the JN-1 area. The thicknesses of the gray and reddish brown till units are variable under the BWJ site, and the information is spatially limited. Figure 6 shows the locations of geologic descriptions that were previously obtained at deep bore sites. Figures $7 \mathrm{a}$ and $7 \mathrm{~b}$ provide a summary of the geological descriptions that have been obtained from the deep bores/wells at the site and from the Camp Ken Jockety area just east of Big Darby Creek. Note that on Figure 7, the top of the reddish brown unit 


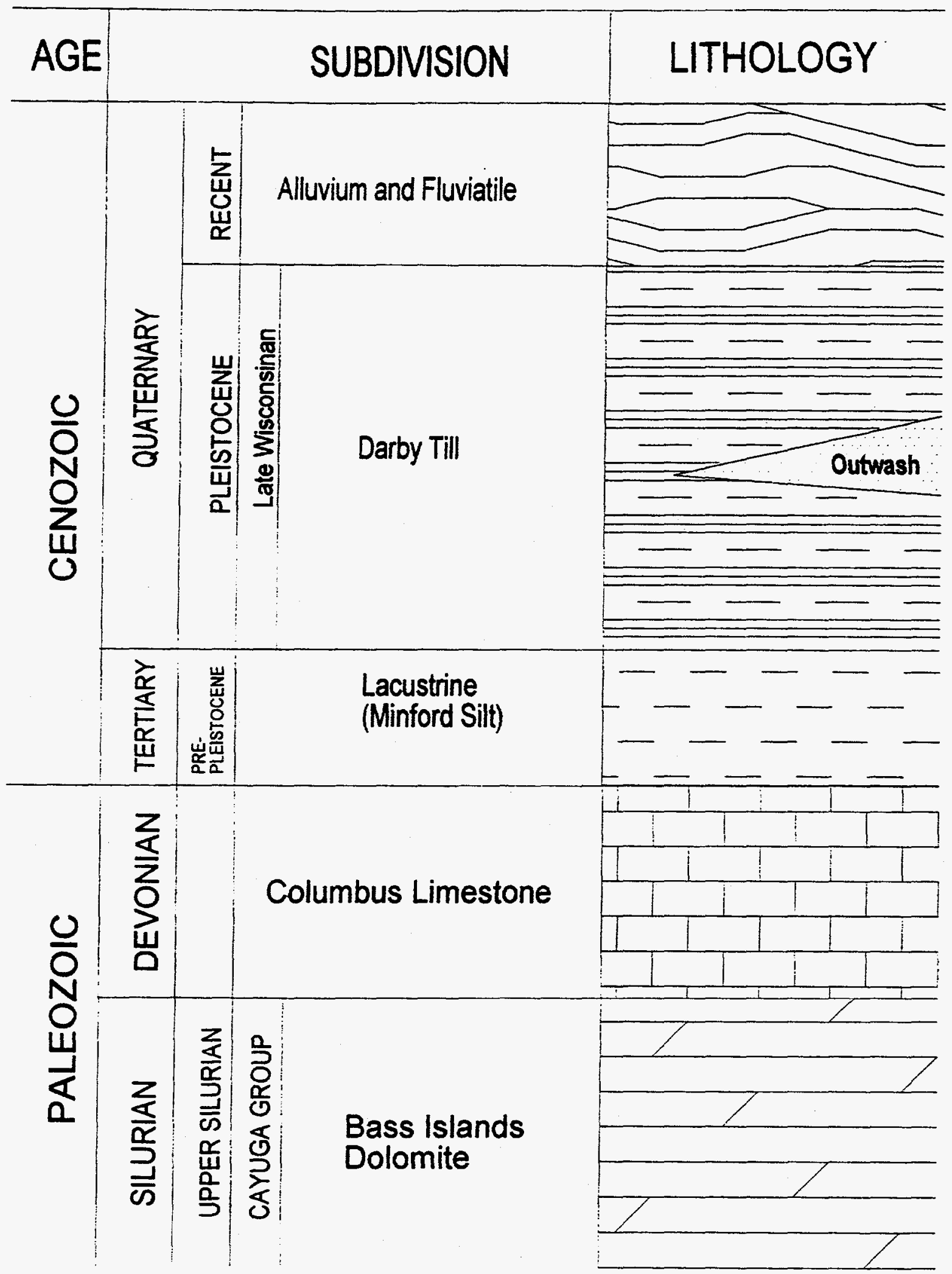

Figure 4. Diagram Showing the Quaternary Surficial Deposits and Silurian-Devonian Formations in Jefferson Township, Madison County, Ohio 

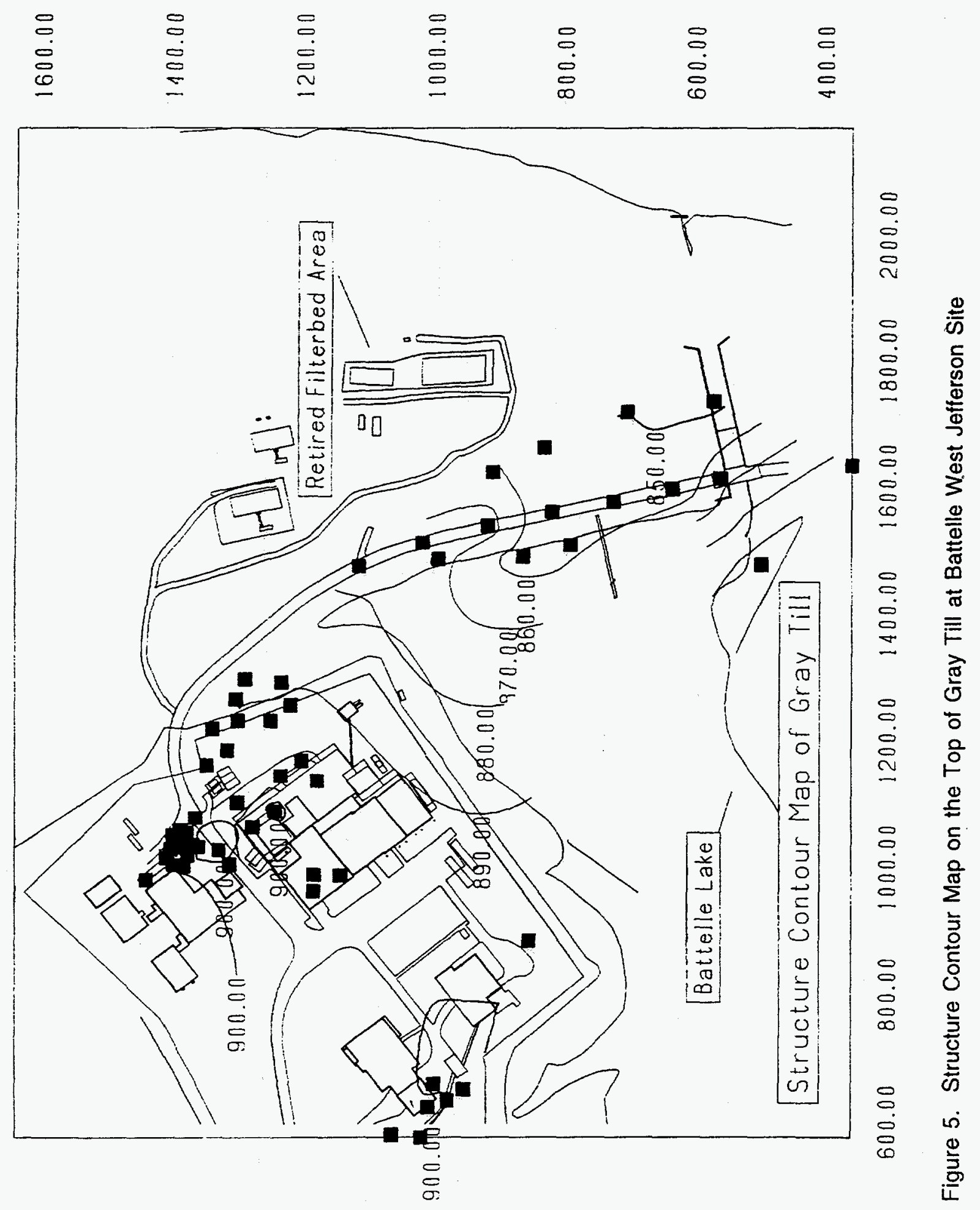


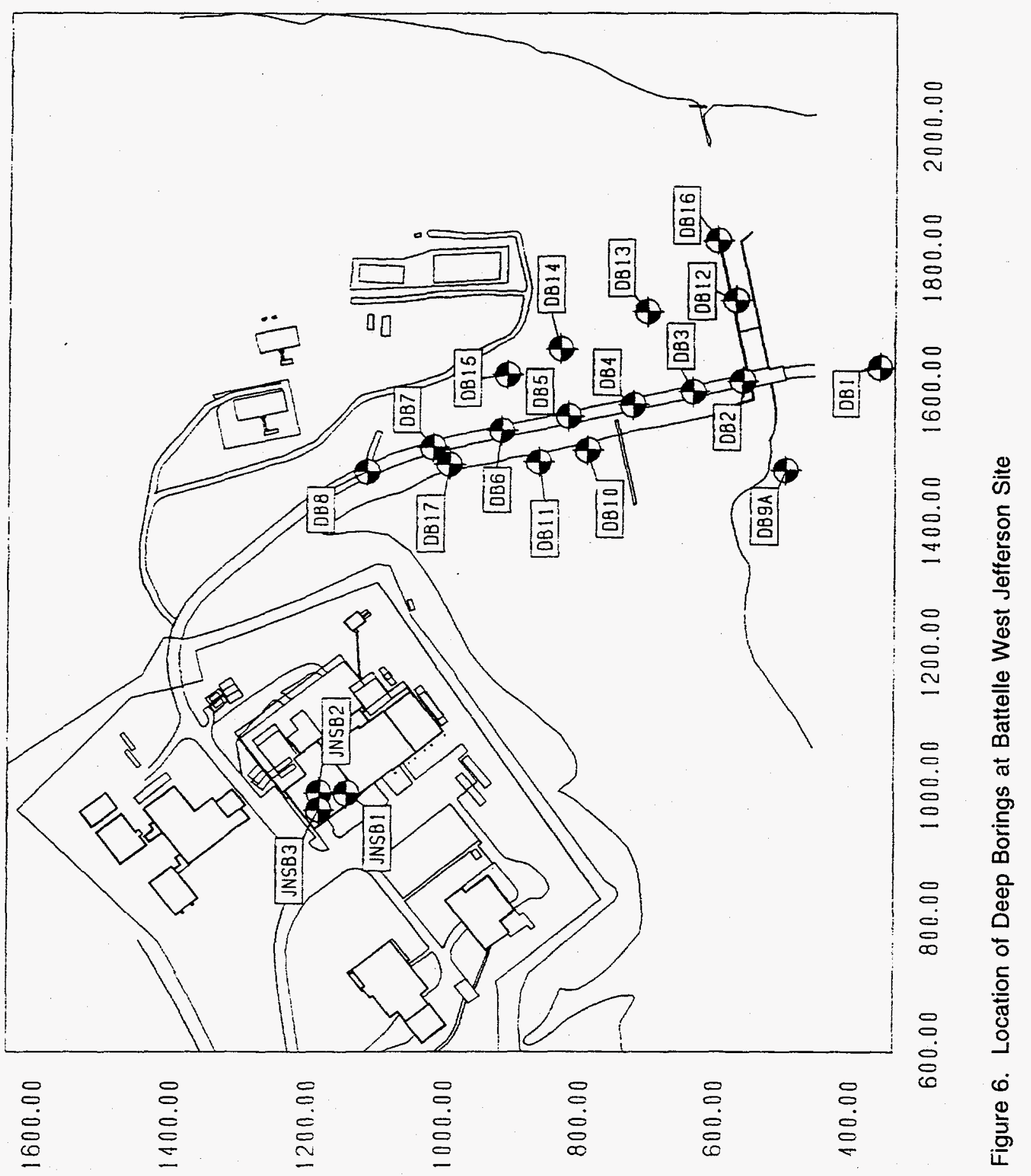




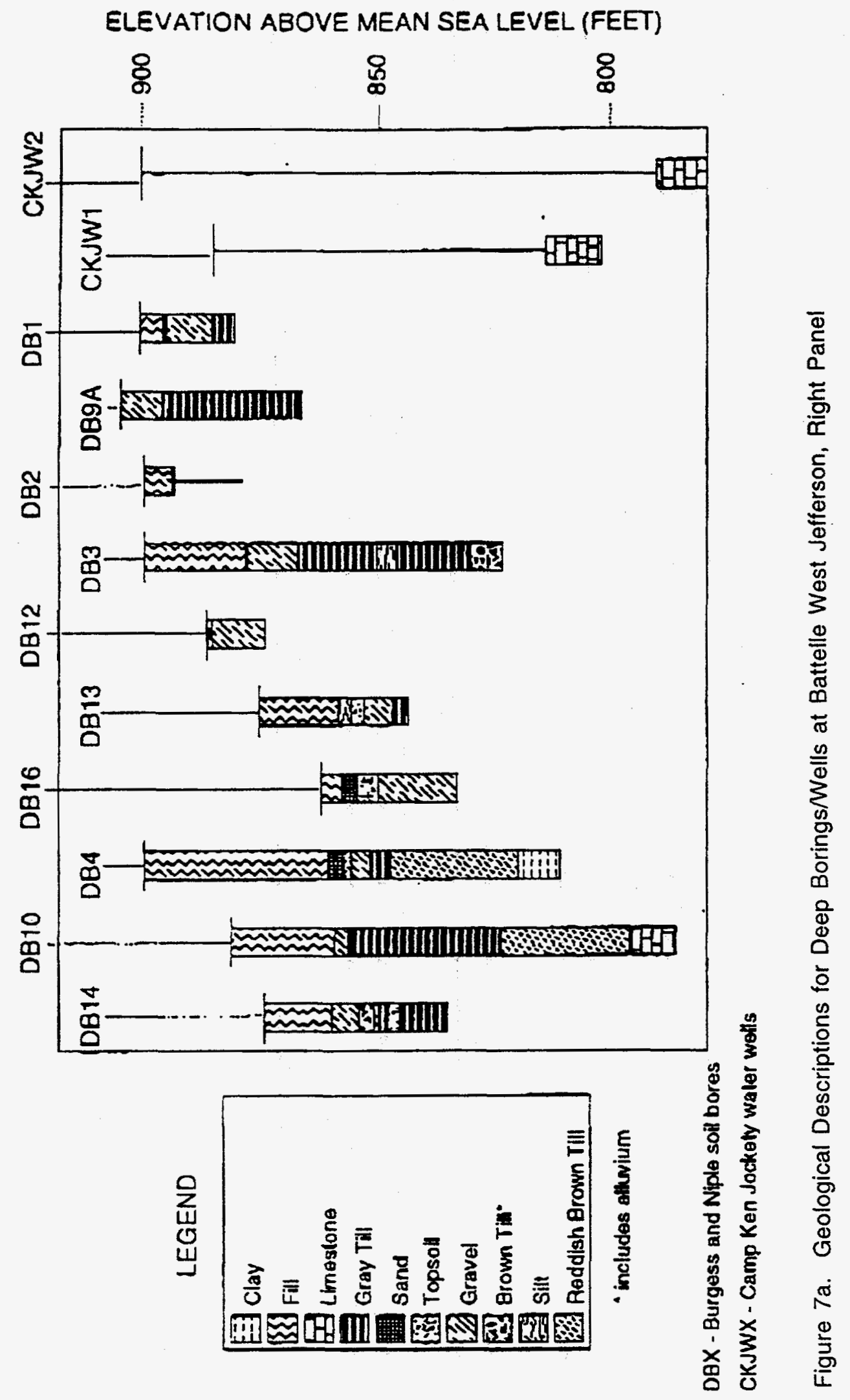




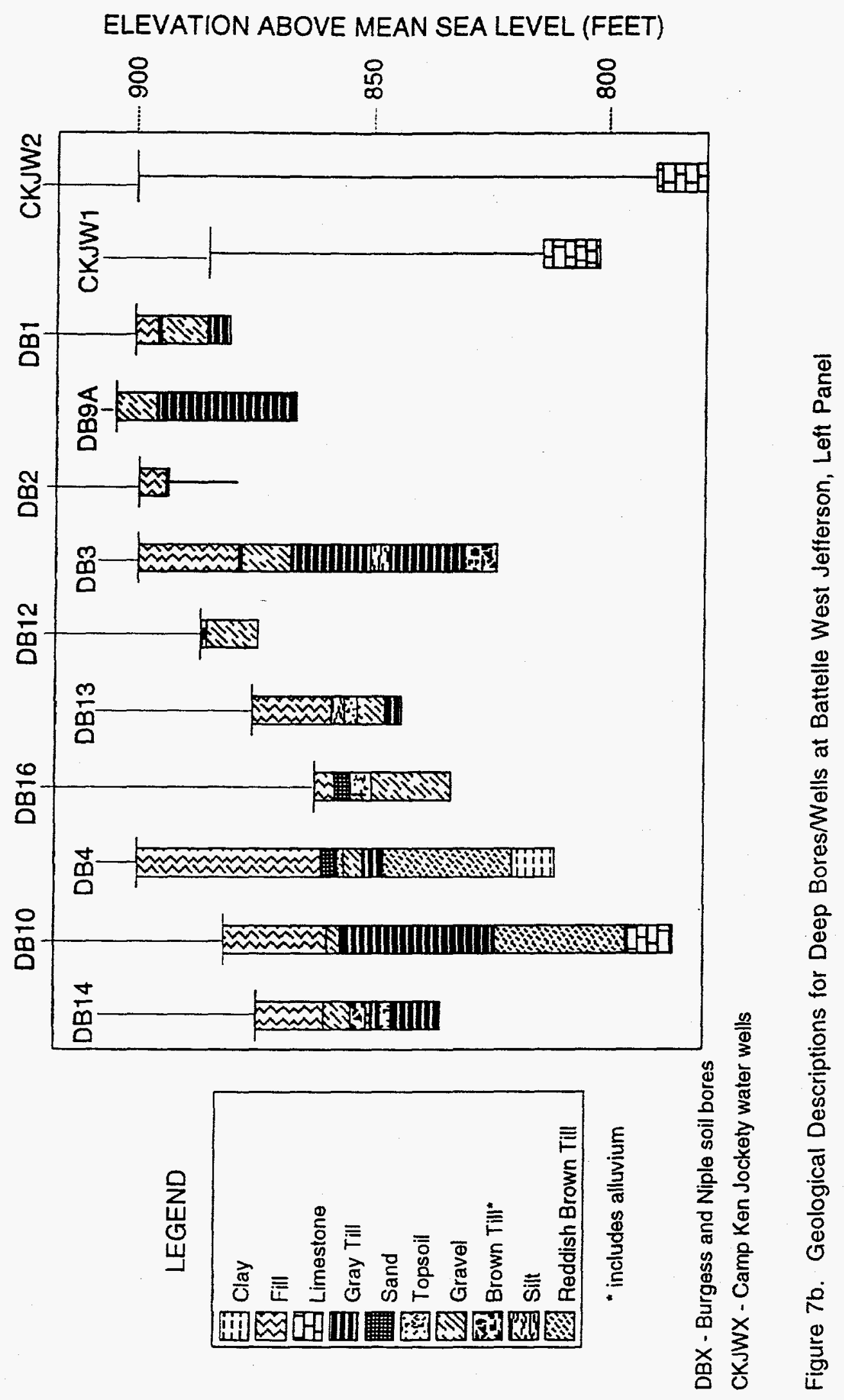


underlying the BWJ site is generally encountered below an elevation of $850 \mathrm{ft}$ above mean sea level.

Review of the Ohio Department of Natural Resources (ODNR) water well logs for the surrounding area indicated that drillers often reported that "red clay" was encountered below depths of 40 to $60 \mathrm{ft}$. Typically, this red clay has been identified just below a gray-blue clay unit or below an underlying sand or gravel unit. On the basis of well $\log$ information and estimated surface elevations, a clay characterized by red color was encountered at an elevation of $830 \mathrm{ft}$ in the Battelle North well and at elevations of 841 and $852 \mathrm{ft}$ in the Camp Ken Jockety wells \#1 and \#2, respectively. It was indicated to range from 20 to $42 \mathrm{ft}$ in thickness.

In previous environmental investigations of the retired filter bed area, between 1988 and 1990, Battelle performed 44 soil bores, which were located both inside and outside the filter bed area. No detailed drawings of the construction of the retired filter beds were available to evaluate the maximum excavation depths. The Battelle soil bores ranged from 10 to $14.5 \mathrm{ft}$ deep, and soil bore logs were prepared for 10 of the holes (R135-R144). Review of the available logs for the retired filter bed area indicated that the base of the fill averaged a depth of $6 \mathrm{ft}$ and was as deep as $9 \mathrm{ft}$ in one location (R138). In the floodplain area, Battelle soil investigations were shallow, and the thickness of the till beneath the alluvial and fill materials was not ascertained. Glacial till was observed at the bases of six of the Battelle environmental soil bores that were performed at the retired filter bed area.

\subsubsection{Outwash and Alluvium Deposits}

Beard and Gupta (1990) have mentioned that near the Storm Sewer Outfall at the BWJ site (also referred to as Area 1) sandy silty layers that overlie the glacial till along the north bank of Silver Creek (Area 1) are either outwash or alluvium deposits (Figure 8). It is not known, however, if the granular materials described by Beard and Gupta (1990) represent natural deposition or if they may possibly involve fill related to the dam construction. Norris (1959) indicated that the Little Darby Creek valley near West Jefferson features extensive valley train deposits (outwash deposits) that constitute an undeveloped aquifer.

A coarse-grained interval was encountered in the Battelle soil bores at the retired filter bed area below the reported depth of fill and above the identified till. The interval consists of silty sand, gravelly sand, and sand and gravel sediments; this unit was directly underlain by till in six bores. Figure 9 provides a geologic profile based on soil bore data at the retired filter bed area. Although the available soil bore data offer useful information about the glacial and recent stratigraphy in the retired filter bed area, there are some inherent limitations in the reported accuracy of the observations due to the sampling procedures that were employed. Soil cores were continuously collected in plastic liners, but the descriptions of soils were limited to visual examination through the transparent liner and to direct observation at the ends of the liners. Nevertheless, review of the soil characterization data did illustrate that granular sediments (probable outwash deposits) underlie the retired filter bed area. This interpretation would also be 

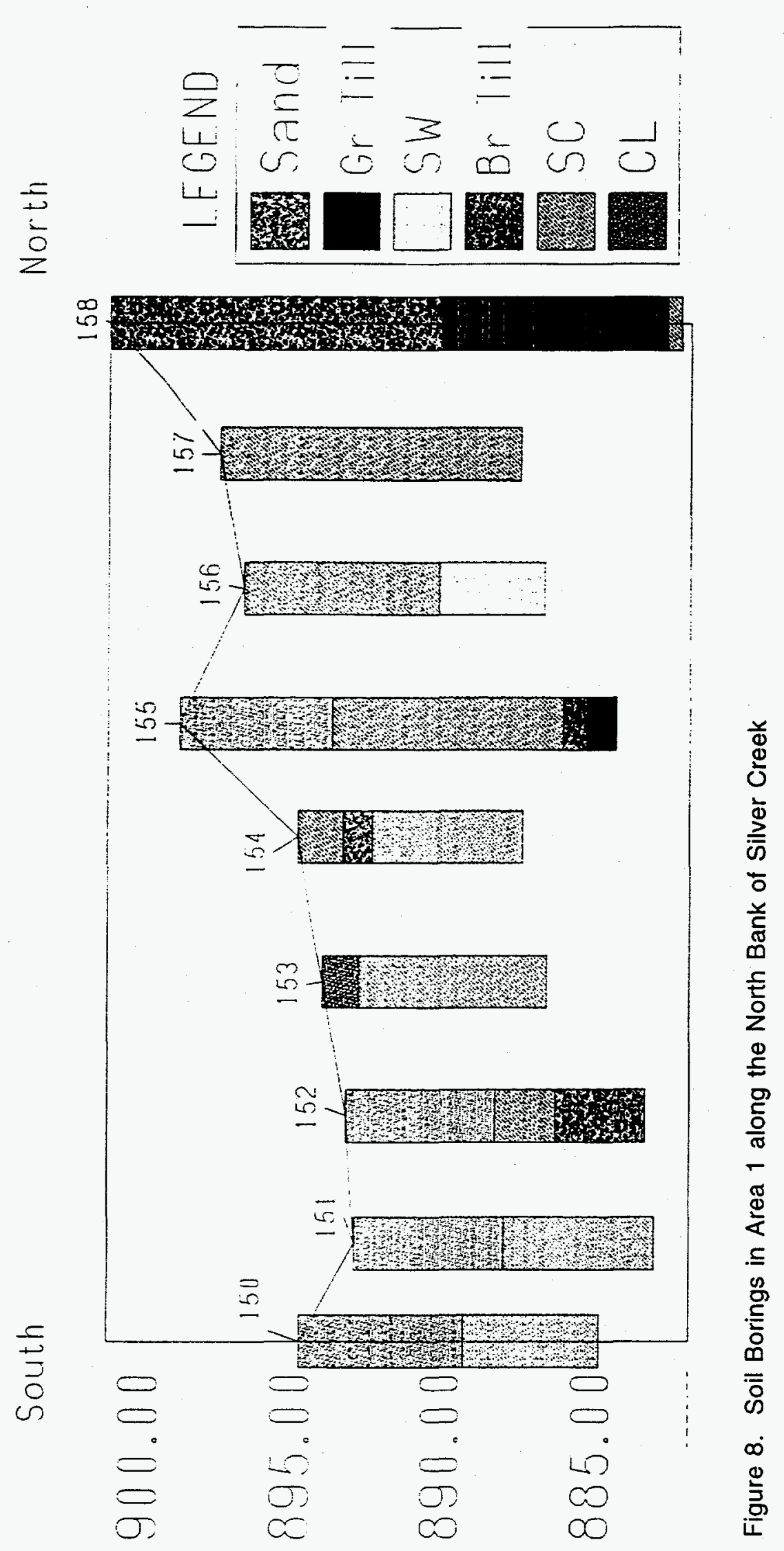


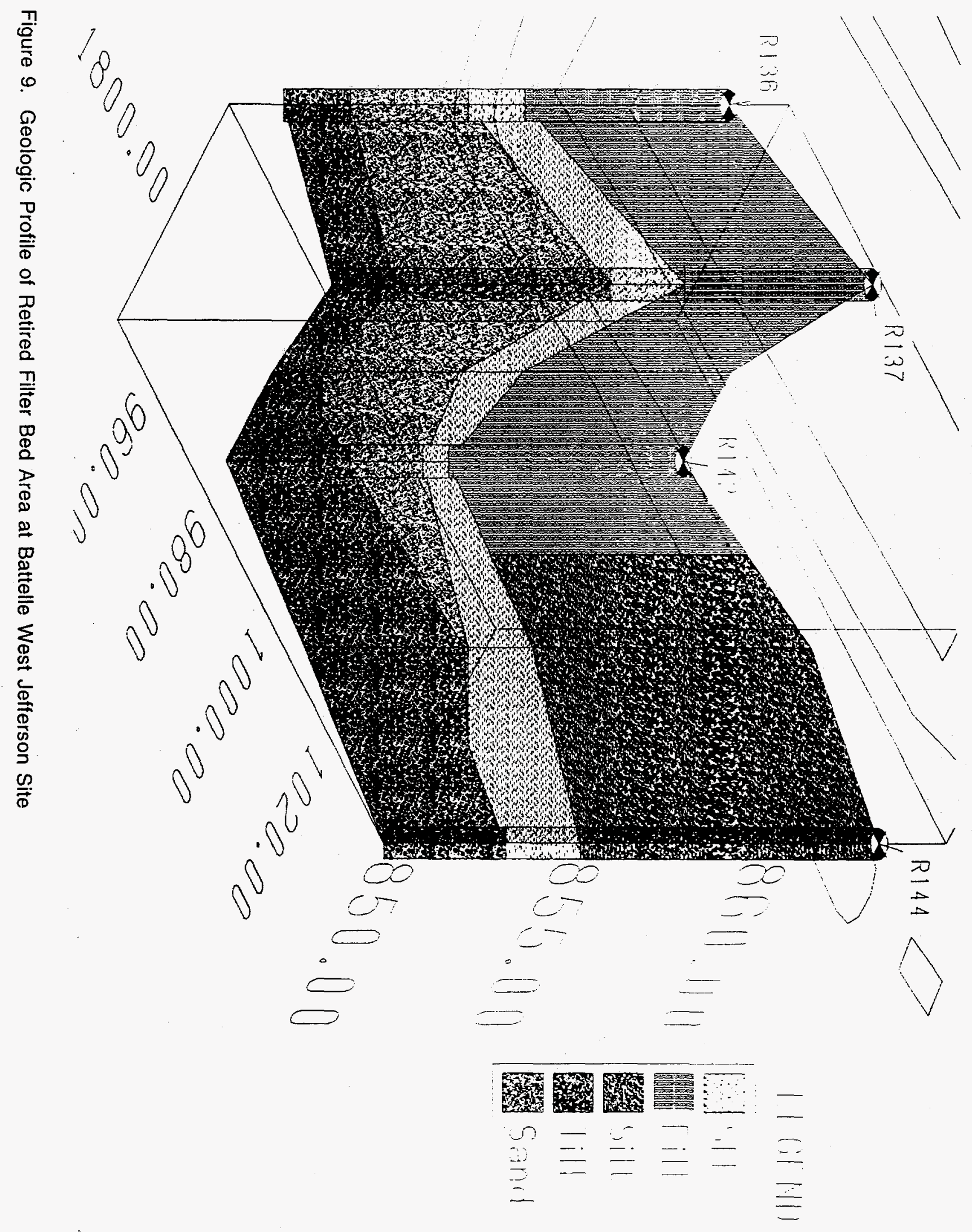


consistent with what is known about the surficial geology in the region. Concerning the recent deposits, Norris (1959) reported that recent alluvium deposits are present along the floodplains in Madison County as thin layers, consisting of sand and silt. Beard and Gupta (1990) reported that the alluvium in the vicinity of the Big Darby Creek floodplain consists "primarily of stratified silt, fine to medium sand, and clay" and that "very thin layers of fine sand were also observed in the clay/silt zones." They also mentioned that the color of the alluvial deposits was "black, gray, red, or brown, and was mottled" in response to the oxidation/reduction environments.

\subsubsection{Lacustrine Deposits}

Remnants of lacustrine deposits locally underlie the glacial till (Battelle 1961). More extensive lacustrine deposits were also recognized by Norris and Spicer (1958) in their investigation of the ancient Teays River Valley system in Champaign, Clark, and Madison counties. Figure 10 illustrates where the Teays River Valley and related preglacial rivers once existed in Ohio and other nearby states (Teller and Goldthwait 1995).

Bigham et al. (1991) characterized the Minford unit through study of trace elements and particle size distribution, on samples collected near Waverly, Ohio, and from locations in Pike, Jackson, and Scioto counties, Ohio. Table 1 provides a comparison of Bigham's (1991) characterization of the Minford sediments, based on grain size, with information for the lacustrine deposits that locally underlie the Battelle site. Minford sediments were penetrated in two, possibly three, bores that were conducted by Battelle in 1961 to investigate the unconsolidated materials underlying the Silver Creek valley, a tributary to Big Darby Creek. The lacustrine clay is gray to reddish-brown in color with carved or laminated structures. Figures $7 \mathrm{a}$ and $7 \mathrm{~b}$ illustrate where the lacustrine deposits have been recognized in soil bore data. Numerous soil borings (with detailed descriptions) and a suite of soil mechanics tests were performed at that time to investigate the site prior to the design and construction of the Battelle Dam.

\subsubsection{Fill Materials}

Artificial materials are present at the BWJ site at both the JN areas, in the dam area, and along the floodplain areas of Big Darby Creek. These materials are present at the site due to previous construction activities and underground piping and utility installations. The fill composition varies, depending on whether native materials were solely utilized or if fill was brought in from another area, either on- or off-site. Some granular fill was also emplaced in the retired filter bed area as filter material. According to Beard and Gupta (1990), two types of fill are present at the BWJ site, general fill and engineered fill. General fill consists of reworked native materials, with some addition of crushed rock, and is density-controlled. Engineered fill consists of native or nonnative materials that are emplaced under engineering specifications. 


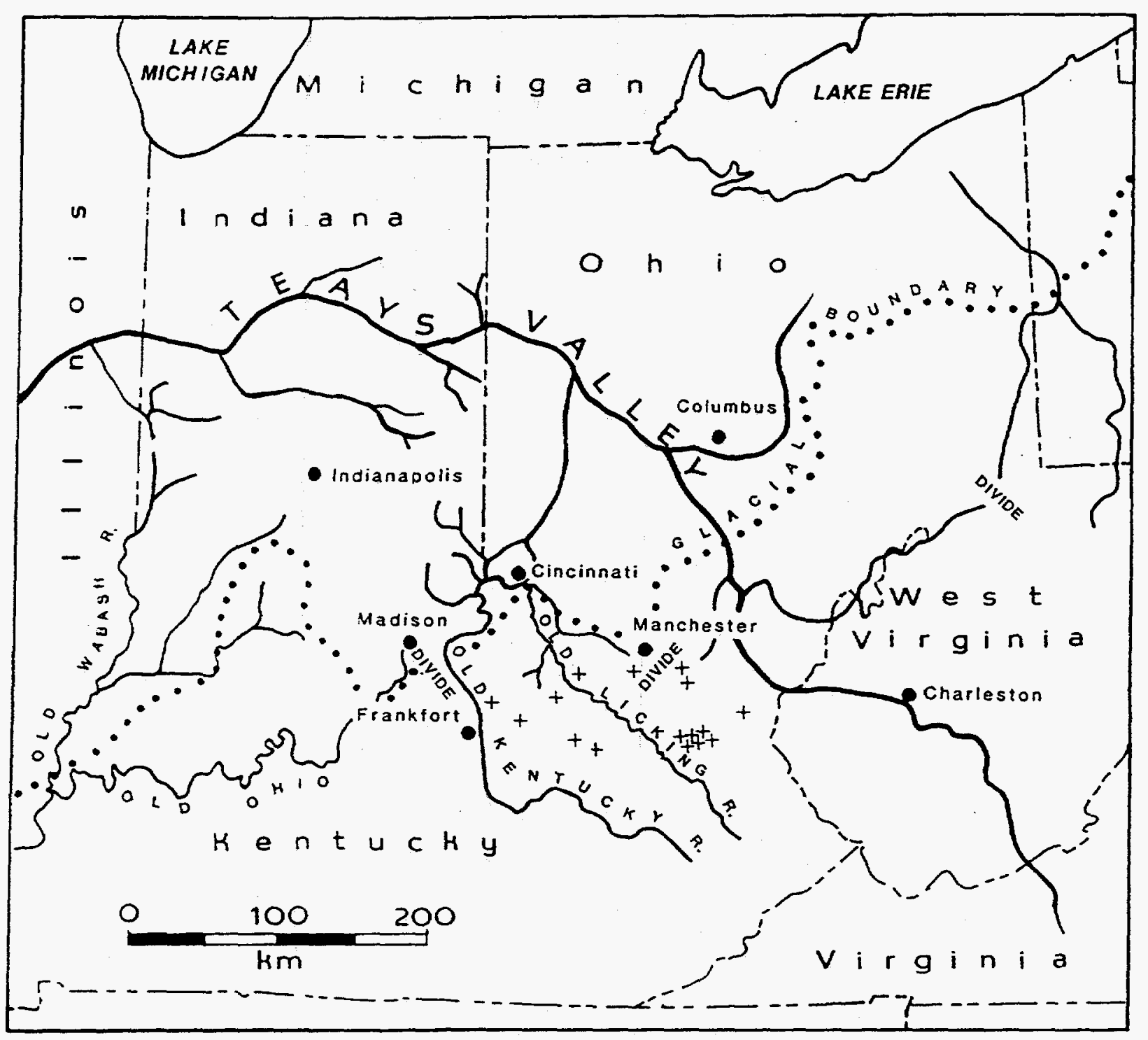

Figure 10. Location of Teays River and Related Preglacial Drainage 
Table 1. Comparison of Particle Size Distributions in Lacustrine Clay (Minford Clay) at Battelle West Jefferson Site

\begin{tabular}{lcc}
\hline Data Source & Clay & Silt \\
\hline Battelle Dam $^{\mathrm{a}}$ & & \\
Bore 4, 28.5-30 ft & 67 & 23 \\
Bore 5, 48.5-50 ft & 59 & 20 \\
Bore 5, 63.5-65.0 ft & 88 & 9 \\
Minford Data (1991) & & \\
$\quad$ Taylor Hill Road Section, Waverly, Ohio & \\
Pike, Jackson, Scioto, Ohio Sites & \\
& 71.9 & 27.9 \\
Post-Minford Data & 73.5 & 25.4 \\
Pike, Jackson, Scioto, Ohio Sites & & 56.0 \\
\hline
\end{tabular}

- Depths reported from original ground surface.

- Note that percentages are mean values.

- Reported ranges for clay and silt fractions were 59.1-86.3 and 13.7-40.9, respectively.

Reported ranges for clay and silt fractions were 64.3-84.3 and 15.5-35.2, respectively.

- Reported ranges for clay and silt fractions were 18.9-64.2 and 29.4-70.8, respectively.

\subsubsection{Bedrock}

Elevation of the bedrock surface was estimated, from previous Battelle studies, to be approximately 791 to $797 \mathrm{ft}$ below mean sea level in the northern part of the BWJ area. Available bedrock information consists of the geotechnical bore and water well records that BCLDP personnel obtained from the Ohio Department of Natural Resources, Division of the Geological Survey. Our review of well records also included information on water supplies for the Camp Ken Jockety property, which is located on the eastern side of Big Darby Creek near BWJ.

Review of the bedrock topography map of Norris and Spicer (1958) indicates that a major, subglacial tributary valley appears to connect the BWJ area with the main trunk of the buried Teays Valley to the southwest (Figure 11). Bedrock topography maps compiled by the ODNR, Division of the Geological Survey, between 1990 and 1993 were also reviewed and generally agreed with the results obtained by Norris and Spicer (1958). While the main trunk of the Teays River Valley may possess $400 \mathrm{ft}$ of relief from the general land surface, according to Norris and Spicer (1958), some of the ODNR test holes also encountered lacustrine clay in the shallower portions of the valleys. Their results for the southeastern Madison County area indicate that ODNR Test Hole 


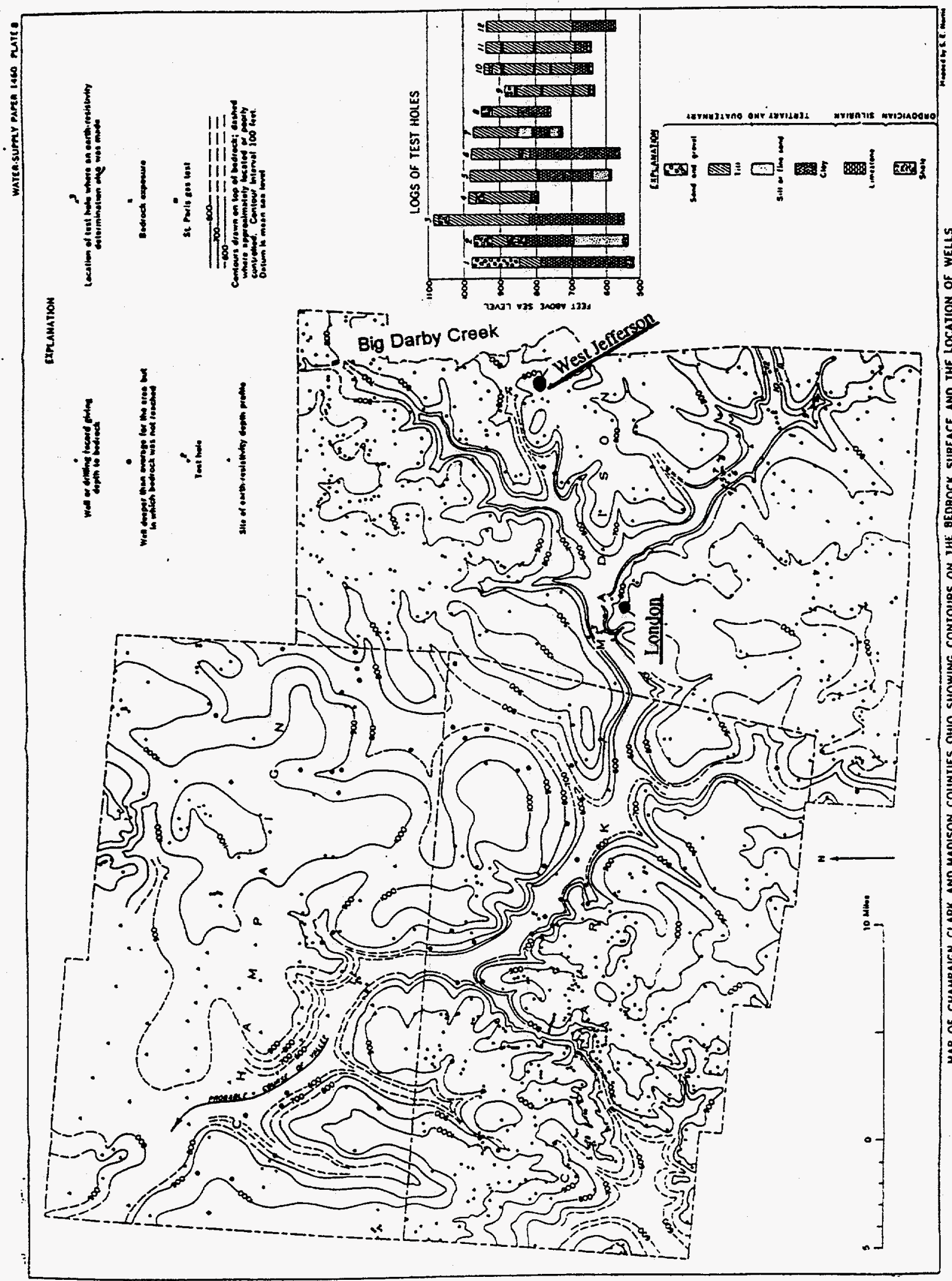

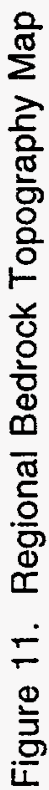


No. 8, located along the edge of a buried valley, penetrated approximately $90 \mathrm{ft}$ of lacustrine clay, where bedrock elevation is approximately $760 \mathrm{ft}$. They also indicate that the $850-\mathrm{ft}$ elevation of those lacustrine deposits at Test Hole No. 8 is the highest occurrence in Madison County.

Groundwater supplies are obtained from the limestone and dolomite rocks that underlie that BWJ site. Klaer and Associates (1963) evaluated the carbonate aquifer at BWJ for the north and middle wells. The tests showed that the yields were 250 gallons per minute (gpm) from the north well and $500 \mathrm{gpm}$ from the middle well. 


\section{Equipment and Procedures}

\subsection{Electromagnetic, Resistivity, and Magnetic Measurements}

\subsubsection{Electrical Conductivity Mapping with the EM-31 and EM-34}

Apparent conductivities in the West Jefferson site were measured by means of the Geonics EM-31 and EM-34 electromagnetic (EM) induction instruments. The induction coil of the EM-31 and EM-34 transmits an EM field into the ground, and a receiver measures the secondary electromagnetic field caused by the low-intensity eddy currents induced in the subsurface. The field strength of the secondary currents is almost linearly proportional to the electrical conductivity of the surrounding sediment. The effective depth of penetration is determined by the coil spacing and coil orientation. Conductivities are dependent upon the moisture content and sediment/rock mineralogy. Although the EM-31 provides an effective depth of penetration (approximately $19 \mathrm{ft}$ ), the conductivities at roughly $7.7 \mathrm{ft}$ in depth are weighted most heavily (McNeill 1980). Data were collected at 0.5-s intervals with the EM-31 and were stored on the OMNI 720 data logger, which can $\log$ quad-phase electrical conductivity data and in-phase inductive data for metals simultaneously, as well as storing survey geometry. For this survey, data were recorded in both quad-phase and in-phase. Internal software permits downloading data directly into an on-site computer.

Apparent conductivities (in $\mathrm{mS} / \mathrm{m}$ ) were obtained with the EM-34 by holding the transmitting and receiving coils on the earth's surface in the same vertical plane (horizontal dipoles) at a spacing of $65.6 \mathrm{ft}(20 \mathrm{~m})$. The apparent conductivity values represent weighted averages of the conductivities of the unconsolidated deposits and rocks between the earth's surface and a maximum depth of approximately $49.2 \mathrm{ft}(15 \mathrm{~m})$, with the conductivities of geologic units near the Earth's surface weighted most heavily (McNeill 1980). The EM-34 complements the EM-31 observations by providing an understanding of the distribution of electrical conductivities with depth. A longer coil spacing $(40 \mathrm{~m})$ was not possible due to cultural interference from the oil pipeline and the metal fencing. Data were collected at 33-ft intervals along $\mathrm{N}-\mathrm{S}$ lines and were manually recorded in field notebooks.

\subsubsection{Vertical Electrical Sounding}

Vertical electrical soundings (VES) using the ABEM/BOSS Wenner system were conducted at 20 locations from the dam road to the east. These soundings were used to calibrate the EM data and also to obtain information on depth to bedrock. Twelve soundings were conducted on the floodplain of the creek and eight along the road crossing the dam. One deep sounding using the Schlumberger technique with a maximum-current electrode separation of $600 \mathrm{~m}$ was conducted on Route 142, located due west of the survey area and centered between the main facility gate and the south access road.

Apparent resistivities were inverted to layering parameters (resistivities and thickness). Resistivities ranged from 10 to $70 \mathrm{ohm}-\mathrm{m}$ in the overburden; whereas, bedrock resistivities ranged 
from 100 to several hundred ohm-m. Norris and Spicer (1958) indicated that overburden resistivities range from 16 to $155 \mathrm{ohm}-\mathrm{m}$, while resistivities range from 136 to $410 \mathrm{ohm}-\mathrm{m}$ for the limestone bedrock. Wolfe and Richard (1992) published bedrock resistivity values that ranged from 100 to $300 \mathrm{ohm}-\mathrm{m}$ for the limestone/dolomite in this area.

\subsubsection{Magnetic Gradiometer and Cable Locator}

Limited surveys were performed with the Schonstedt MAC-51B magnetic gradiometer and cable locator to assist in defining buried obstacles. It is a dual-mode instrument designed for detecting shallow buried iron and steel objects and tracing underground cables and pipes. The system consists of a transmitter and a dual-function receiver designed to detect anomalous magnetic gradients. The MAC-51B is an audio device used only for rapid detection of magnetic materials for further analysis with complementary instrumentation. A Schonstedt MAC-51B gradiometer was used, in conjunction with the EM-31 data sets, to locate the Shell petroleum pipeline. The trend of pipe was marked across the site with plastic pin flags (Figure 2).

Maps or models are not constructed on the basis of observations made with this instrument because it is not a calibrated system, nor does it have digital data recording. Anomalies are identified by changes in sound amplitude and frequency and are identified on the ground surface with non-metallic markers.

\subsection{Ground-Penetrating-Radar Surveys}

Ground-penetrating-radar surveying and data processing were accomplished by using the Geophysical Survey Systems, Inc., Radan III software (Galinovsky and Levin 1990) and a model SIR-2 radar connected to a transceiver with a cable approximately $100 \mathrm{ft}$ long. The transmitting and receiving antennas were attached to a rigid frame and separated by a fixed distance of $4.5 \mathrm{ft}$. Both the 100 - and $300-\mathrm{MHz}$ antennas were tested in the bistatic mode. The $300-\mathrm{MHz}$ antenna provided the better data and was used at the site. Profiles were collected in a continuous mode. Adjustments in gains were made to limit interference and enhance signal strength. Data from the SIR-2 system were downloaded directly to the personal computer. The computer was located in a field office so that the radar operator could download, check data quality, and do preliminary processing after a day's run.

Wave-velocity characteristics of near-surface materials were derived from tables of traveltime to depth conversion for various earth materials (Geophysical Survey Systems 1987). For example, the two-way conversion to depth for an average soil (fresh-water-saturated clay to silty sand) is $7-9 \mathrm{~ns} / \mathrm{ft}$. As the degree of soil saturation and clay content increase, the maximum penetration depth decreases. At the West Jefferson site, both the 100 - and $300-\mathrm{MHz}$ antennas, in a bistatic configuration, were tested. The GPR profiles collected with the $300-\mathrm{MHz}$ antennas at a range setting of 250 ns provided the best data and were used over the entire site. 


\subsection{Seismic Refraction Profiling}

Seismic refraction profiles were recorded at six sites at BWJ. Energy sources consisted of a 16-lb siedge hammer and a Bison Instrument EWG III weight drop. A 24-channel, EG\&G ES-2401 seismograph was used to record the refraction data, and 14- $\mathrm{Hz}$ geophones manufactured by Geosense, Inc., were used as the receivers. A sampling interval of 0.5 milliseconds (ms) was used for each shot record; the total recording time varied from 256 to $500 \mathrm{~ms}$, depending on the shot-receiver geometry. Geophone spacings were 5 and $10 \mathrm{~m}(16.7$ and $32.1 \mathrm{ft})$. For the refraction lines on the dam and south entrance road, the geophone spacing was $10 \mathrm{~m}(32.1 \mathrm{ft})$. Five-meter $(16.7-\mathrm{ft})$ geophone spacings were used for the four profiles near the filter beds. A maximum shot-to-far-detector distance of $392 \mathrm{~m}(1,286 \mathrm{ft})$ was achieved along the dam road seismic profile (Line-1), and a maximum shot-to-far-detector spacing of $180 \mathrm{~m}(590 \mathrm{ft})$ was used for the profiles acquired on the floodplain. All profiles were shot in reverse directions to correct for apparent dip on refracting surfaces. The refraction data were processed by using the SIPT program of Scott (1973 and 1977), which is a robust seismic refraction inversion program that uses iterative ray tracing and model adjustment to produce a velocity-depth model.

\subsection{Cone Penetrometer Testing}

Cone penetrometer testing (CPT) was accomplished at BWJ during the week of September 18, 1995. The CPT tests performed for this investigation were conducted using a 30-ton Applied Research Associates (ARA) penetrometer truck. Electronic cone penetrometers consist of cones at the ends of one-meter sections of 1.7-in-diameter steel rods that are pushed into the ground with hydraulic rams. At BWJ. the cone was configured to measure tip resistance, sleeve resistance, pore pressure, and electrical resistivity. The data from the cone sensors is transmitted to the surface from the probe assembly via a cable running through the push rods. The analog data are digitized, recorded, and plotted by computer in the CPT truck. The depth of penetration is measured by using a string potentiometer mounted on the hydraulic rams. The CPT was performed in accordance with ASTM-D3441 procedures. Cone sensors were checked and calibrated prior to the start of each day or when sensors were replaced.

Tip resistance and sleeve friction together measure the geotechnical properties (strength, compaction, cohesiveness, etc.) of the material being penetrated. As the cone is pushed through a cohesive clay horizon, the cone forms a cavity with relatively little caving-in of the walls. Consequently, both the tip resistance and sleeve friction are relatively low. In low sandy horizons with a low degree of compaction, the less cohesive material generally is difficult to push aside and is likely to keep caving in on the cone, resulting in higher tip resistance and possibly higher sleeve friction. Because of the disturbance of the material around the cone during penetration, in-situ pore pressures are altered. Significantly high pore pressures are developed in cohesive materials with lower permeability, such as clays, because of consolidation around the cone. Pore pressures may also increase initially in sand layers with higher permeability, but the buildup is relatively less compared with clay layers.

Electrical resistivity was also measured during the $\mathrm{CPT}$ investigation at $\mathrm{BWJ}$. The resistivity probe consisted of four electrodes separated by high-strength, plastic-reinforced 
insulators. The two outer electrodes induce an electric current into the soil, and the two inner electrodes measure the potential drop, which is proportional to the resistivity of the soil. The resistivity is useful for better defining lithologic boundaries. Higher resistivities indicate vadose zone sands and saturated sands below the water table. Lower resistivity measurements indicate an increasing clay content, even when obtaining readings below the water table.

Upon completion of each CPT hole, the rods were removed, steam-cleaned, and screened for radiological contamination by Battelle. Wastewater was placed in containers until after equipment screening and then properly disposed of by BCLDP personnel.

The ability to effectively use CPT to characterize site geology has been reported in literature by Smolley and Kappmeyer (1991), Chiang et al. (1992), and Zemo et al. (1994). Those investigators reported that they used CPT soundings to define stratigraphy, recognize electronic log signatures indicating major changes in lithology, and identify preferred pathways for migration of contaminants. In those reports, the stratigraphy was unraveled through application of published charts (e.g., Robertson and Campanella 1986) that correlate CPT responses to soil behavior and control points where detailed soil descriptions were obtained from on-site bores. Smolley and Kappmeyer (1991) reported success in applying CPT soundings to screen for well locations that met a state regulatory criterion involving a minimum of three feet of aquifer thickness. In the published studies, various investigators have used CPT soundings to determine the optimal location and number of groundwater monitoring wells.

\subsection{Piezometer Installation}

Six shallow piezometers were installed near the retired filter bed area of BWJ. The piezometers were installed by means of an innovative method that involved the use of the CPT truck. Initially, a pilot hole was pushed to within 1-2 ft above the desired well completion depth, using 1.4-in-diameter penetrometer push rods. The rods were then removed, steam-cleaned, and screened for radiological contamination. All six wells were installed by advancing a 1.5-in-I.D., schedule 80 PVC pipe down the pilot hole outside the 1.4-inch-O.D. penetrometer push rods. A sacrificial steel tip was matched to the outside diameter of a PVC slotted screen, thus leaving no annular space and eliminating the need to backfill and grout. Once the desired depth was reached the penetrometer push rods were withdrawn, leaving the piezometer pipe, screen, and tip in place (Figure 12).

Each piezometer was constructed with a one-meter-long slotted PVC screen and approximately one meter of riser pipe extending above the ground surface. An outer, 4-in.diameter, schedule 40 PVC casing was cemented around the inner casing and fitted with a sealed, locking cap. The piezometers were all developed by bailing several well volumes (when feasible). Development water was containerized and properly disposed of by BCLDP personnel. 


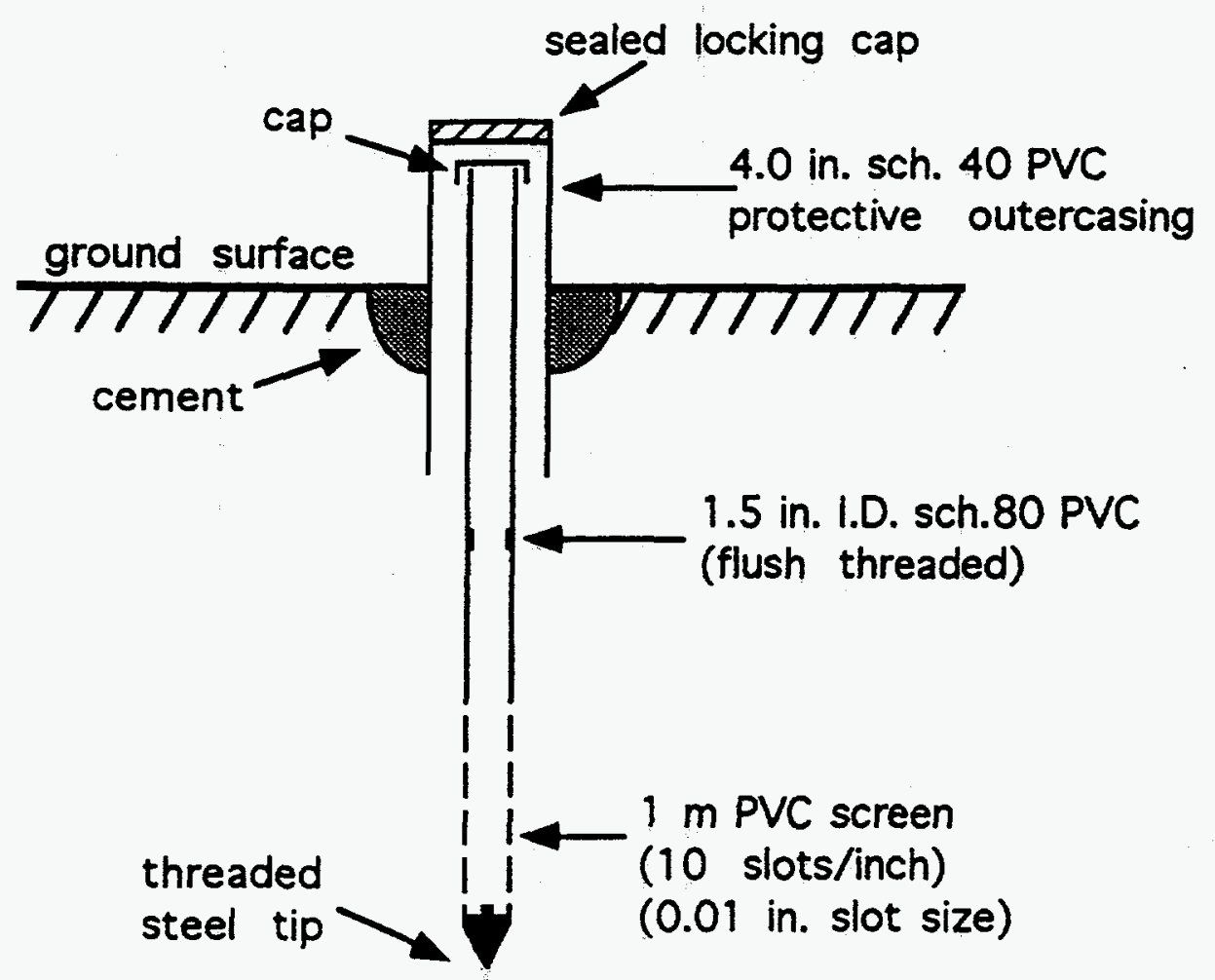

Figure 12. Schematic Drawing of Piezometer Construction 


\subsection{Surveying}

A $100 \mathrm{ft}$ by $100 \mathrm{ft}$ grid was established over a $600 \mathrm{ft}$ by $525 \mathrm{ft}$ study area by Woolpert of Columbus, Ohio, in September 1995, to provide ground control for nonintrusive geophysical surveys. The grid corners and grid nodes were also surveyed for elevations. CPT locations were surveyed for coordinates and ground elevations. Well points were surveyed for coordinates and for ground and top of riser pipe elevations. All elevations were based on the United States Geological Survey (U.S.G.S.) data for the area.

In the fall and winter of 1995-1996, as the data were analyzed, it became apparent to the investigators that the elevations for the existing 2-in. PVC groundwater monitoring wells at the BWJ retired filter beds were suspect. Approximately 13 wells were installed at that location in 1990 by Battelle; these wells were previously surveyed by R.T. Patridge and Associates. The elevations for the tops of the PVC monitoring well casings were suspected to be incorrect when recent groundwater measurements obtained in the existing wells and well points were utilized to plot contours of equal groundwater elevation. R.T. Patridge and Associates were contacted and asked about previous survey records, and in January 1996, they provided copies of the previous survey records that had been completed for Battelle. After available data were checked with Patridge and Associates, they indicated to us in January that the elevations in question were probably casing elevations.

Consequently, Woolpert returned to the BWJ site on April 21, 1996, to resurvey the ground surface and the tops of the casing elevations for the 13 Battelle 2-in. monitoring wells in the retired filter bed area. Woolpert determined that due to differences in data selection (R.T. Patridge data vs. U.S.G.S.), the previous data would need to be shifted $-0.79 \mathrm{ft}$ and that after accounting for the data shift, the previous casing elevations were not correct. Table 2 shows the revised elevation data and the earlier data. 
Table 2. Revised Elevation Data for 2-in. Groundwater Monitoring Wells at the BWJ Retired Filter Bed Area

\begin{tabular}{cccc}
\hline & \multicolumn{2}{c}{ Casing Elevation } & Ground Elevation \\
\cline { 2 - 4 } Well & 1990 Data & 1996 Data & 1996 Data \\
\hline 101 & 861.58 & 863.76 & 860.67 \\
103 & 862.72 & 864.90 & 861.81 \\
110 & 864.50 & 865.47 & 863.36 \\
111 & 865.99 & 868.24 & 865.21 \\
112 & 864.46 & 866.96 & 863.48 \\
113 & NA & 863.65 & 861.10 \\
116 & 863.30 & 865.60 & 862.45 \\
118 & 861.24 & 863.64 & 860.11 \\
122 & 862.59 & 864.97 & 861.72 \\
124 & 862.59 & 865.03 & 861.90 \\
125 & 863.12 & 865.40 & 862.28 \\
129 & 864.02 & 866.80 & 863.18 \\
130 & 863.08 & 865.30 & 862.20 \\
\hline
\end{tabular}

${ }^{a}=$ not available. 


\section{Electromagnetic Surveys}

\subsection{EM-31 Mapping}

EM-31 conductivity profiles were collected along north-south lines spaced at 10-ft intervals. Figure 13 was created by gridding and contouring 16,347 conductivity values collected with the EM-31.

The filter bed area proper is readily apparent, as indicated by a high-conductivity perimeter caused by the surrounding chain-link fence. This area extends from about $675 \mathrm{~N}$ to $960 \mathrm{~N}$ and from $500 \mathrm{E}$ to $760 \mathrm{E}$. Metal covers and pipes, along with electrical utilities, all associated with the water treatment system, are the source of the anomalies within this perimeter.

Another prominent feature in Figure 13 is an abandoned steel petroleum pipeline. It is seen as a conductivity low bordered on either side by a conductivity high. The observed "high-lowhigh" conductivity anomaly is typical of electromagnetic profiles collected perpendicular to a pipeline or cable by using the EM-31 (McNeill 1980). The pipeline enters the survey area near survey coordinate $(940 \mathrm{~N}, 500 \mathrm{E})$ and trends east-southeast until it leaves the survey area at coordinate $(850 \mathrm{~N}, 1050 \mathrm{E})$.

A similar type of anomaly is observed along an east-west trend from (480N, 560E) to $(460 \mathrm{~N}, 880 \mathrm{E})$. It lies south of the geophysical survey area, but some profiles were extended to the south and crossed this feature. The electromagnetic signature is the same as that observed across the petroleum pipeline. A strong conductivity high is present, extending from the southwest corner of the fenced area to the southern edge of the survey. A discharge pipe and corresponding outfall at the eastern end of the dam spillway are associated with this feature.

Two other lineaments (pipes) are indicated by the EM-31 data in the western portion of the survey area. A pipe(s) extends from near the southwest corner of the fenced area (720N, 550E) toward the south-southeast, intersecting the discharge pipe mentioned above at approximately $(480 \mathrm{~N}, 620 \mathrm{E})$. In the northwest corner of the survey area, a linear conductivity minimum, corresponding to a metallic effluent pipe from the north filter site, is located between approximately $(1070 \mathrm{~N}, 500 \mathrm{E})$ and $(1060 \mathrm{~N}, 570 \mathrm{E})$. The truncation of this anomaly is the result of either a change in pipe material and/or depth or the removal of portions of the pipe. The slight nonlinearity is probably due to a positioning error associated with surveying perpendicular to the steep slope that leads to the fenced north filter site. The maxima along the $500 \mathrm{E}$ profile between $980 \mathrm{~N}$ and $1080 \mathrm{~N}$ are associated with this fence.

Other high-amplitude anomalies shown in Figure 13 are seen at about $(600 \mathrm{~N}, 900 \mathrm{E})$ and $(940 \mathrm{~N}, 960 \mathrm{E})$. The source of these generally north-south trending anomalies was noted to be the remnants of a barbed-wire fence. This fence was semicontinuous through the site; it is located about $100 \mathrm{ft}$ west of, and roughly parallel to, the river. 


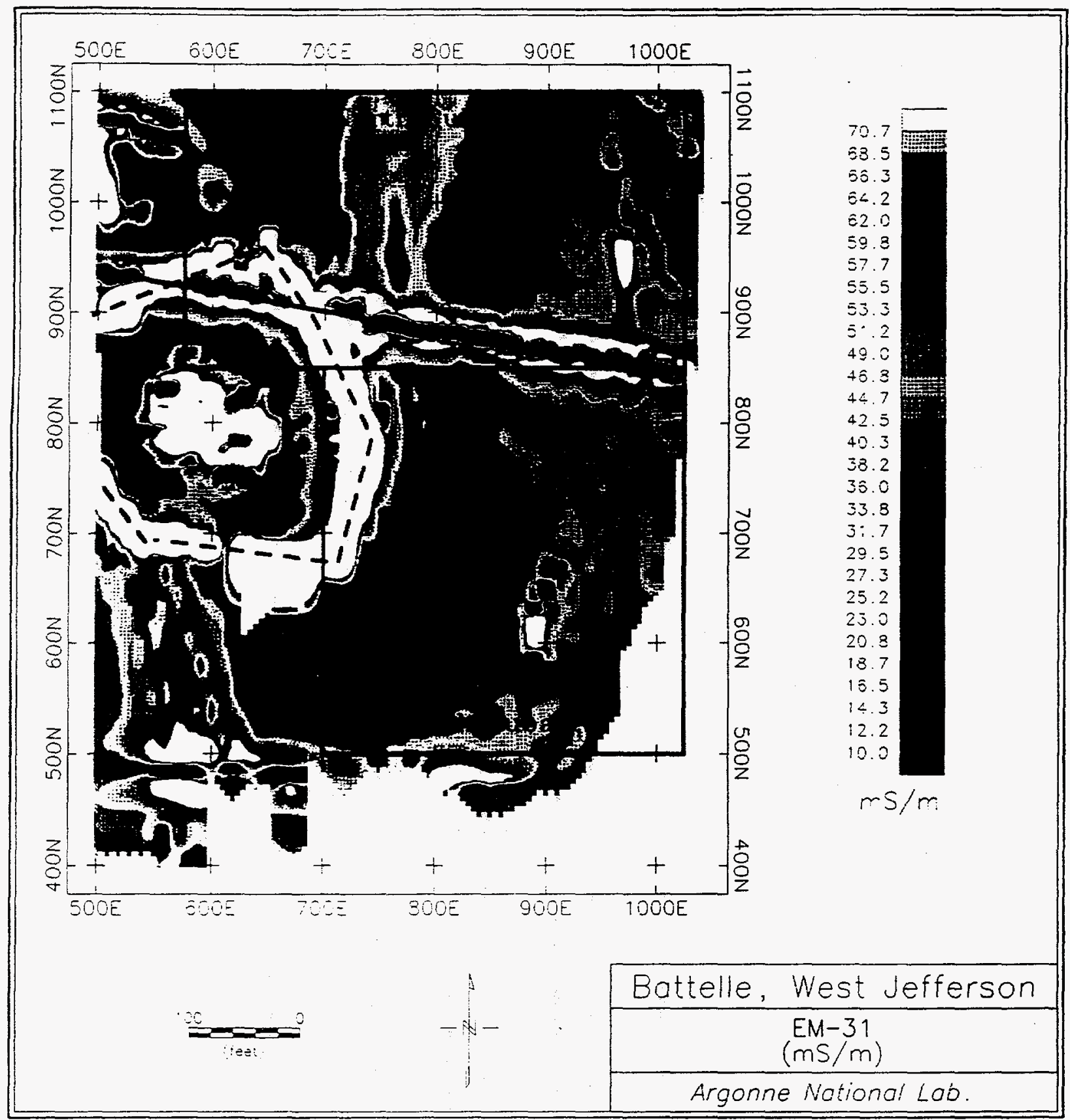

Figure 13. Map of Terrain Conductivity Anomalies Measured by the EM-31 at Battelle West Jefferson 
Two subareas in the northern and southeastern portions of the survey area are outlined in Figure 13 and are enlarged as Figures 14 and 15, respectively. These subareas were contoured with a finer interval in order to examine more subtle features that appear at distances away from the higher-amplitude, anthropogenic anomalies.

The subsurface conductivity of the surrounding area is strongly controlled by the degree of saturation, and subsequently, the topography. Figure 14 shows a conductive zone from about $710 \mathrm{E}$ to $820 \mathrm{E}$. This broad zone, which bifurcates to the south, corresponds with a topographically low, wet area. The relative conductivity minima on either side of this zone have been correlated with higher ground on topographic maps, the low conductivity being suggestive of a lower degree of saturation. South of the pipeline, the lower conductivity area has an elevation a few feet higher than the adjacent material (Figure 15).

Two lineaments are also observed in the data. The first, in the north subarea (Figure 14), extends from about $(1000 \mathrm{~N}, 620 \mathrm{E})$ to $(1020 \mathrm{~N}, 710 \mathrm{E})$ and has a positive amplitude of about $6 \mathrm{mS} / \mathrm{m}$. The second lineament, indicated in Figure 15 as an expansion of the southeast subarea, extends from $(830 \mathrm{~N}, 805 \mathrm{E})$ to $(745 \mathrm{~N}, 915 \mathrm{E})$ and also has a positive amplitude of about $6 \mathrm{mS} / \mathrm{m}$. Also within this expanded portion (Figure 16), other positive EM anomalies, including a U-shaped positive anomaly east of the lineament, are present. These subtle conductivity differences may correlate with previous meander channels of Big Darby Creek. None of the features detected during the survey are thought to represent continuous geologic features, such as thick paleochannel deposits with relatively high hydraulic conductivities in the near-surface zone measured with the EM-31 instrument. Consequently, the EM-31 results did not suggest significant lateral changes in stratigraphy in the shallow subsurface that might serve as preferential groundwater flow pathways.

Figure 17 was generated by using the in-phase component of the EM-31. The in-phase measurements help in delineating anomalies that are produced by metallic objects vs. sedimentological variations. The metallic pipelines, fence, barbed wire, and grates appear clearly in this figure. EM-31 data were also collected in Area 1. These data are presented in Appendix D.

\subsection{EM-34 Mapping}

Apparent conductivities measured with the EM-34, using a $0.50-\mathrm{mS} / \mathrm{m}$ contour interval, are shown in Figure 18. The three-banded conductivity anomaly (high/low/high) caused by the oil pipeline is an artifact of EM measuring devices. Interference effects bias the data, and apparent conductivities within at least $65 \mathrm{ft}$ of this feature are obscured. A similar feature trending approximately $\mathrm{E}-\mathrm{W}$ south of about $500 \mathrm{~N}$ is associated with a discharge pipe and outfall at the Big Darby Creek.

North of the pipeline, the pattern of conductivities seems to be influenced by the degree of ground saturation, which is, in turn, controlled by local topography. The conductivity high along the western border of the survey correlates with a topographically low, wet region. On the other hand, the broad conductivity low corresponds with a topographic high. Within this broad conductivity low is a narrow, 4-mS/m minimum of unknown origin. 


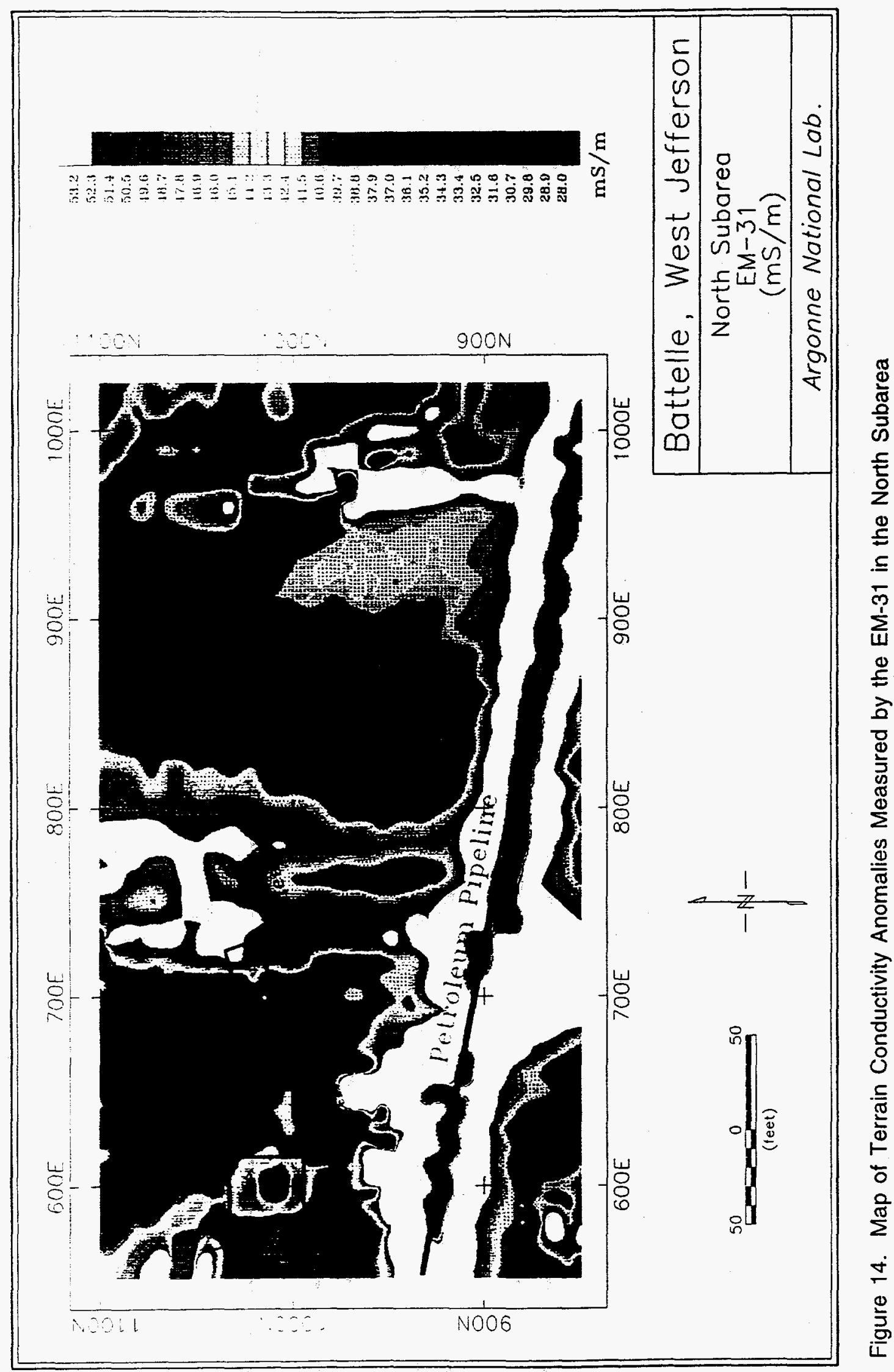




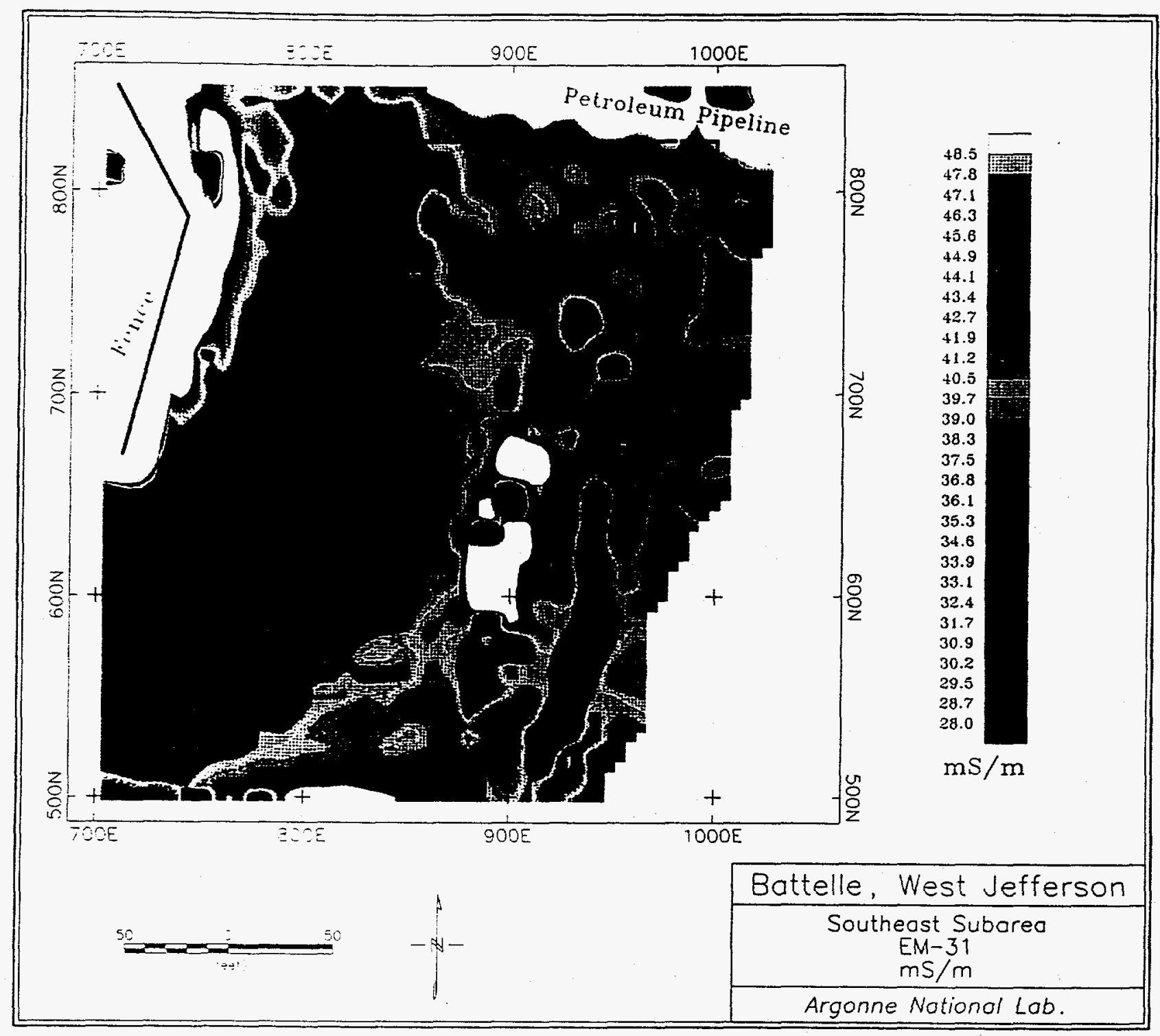

Figure 15. Map of Terrain Conductivity Anomalies Measured by the EM-31 in the Southeast Subarea 


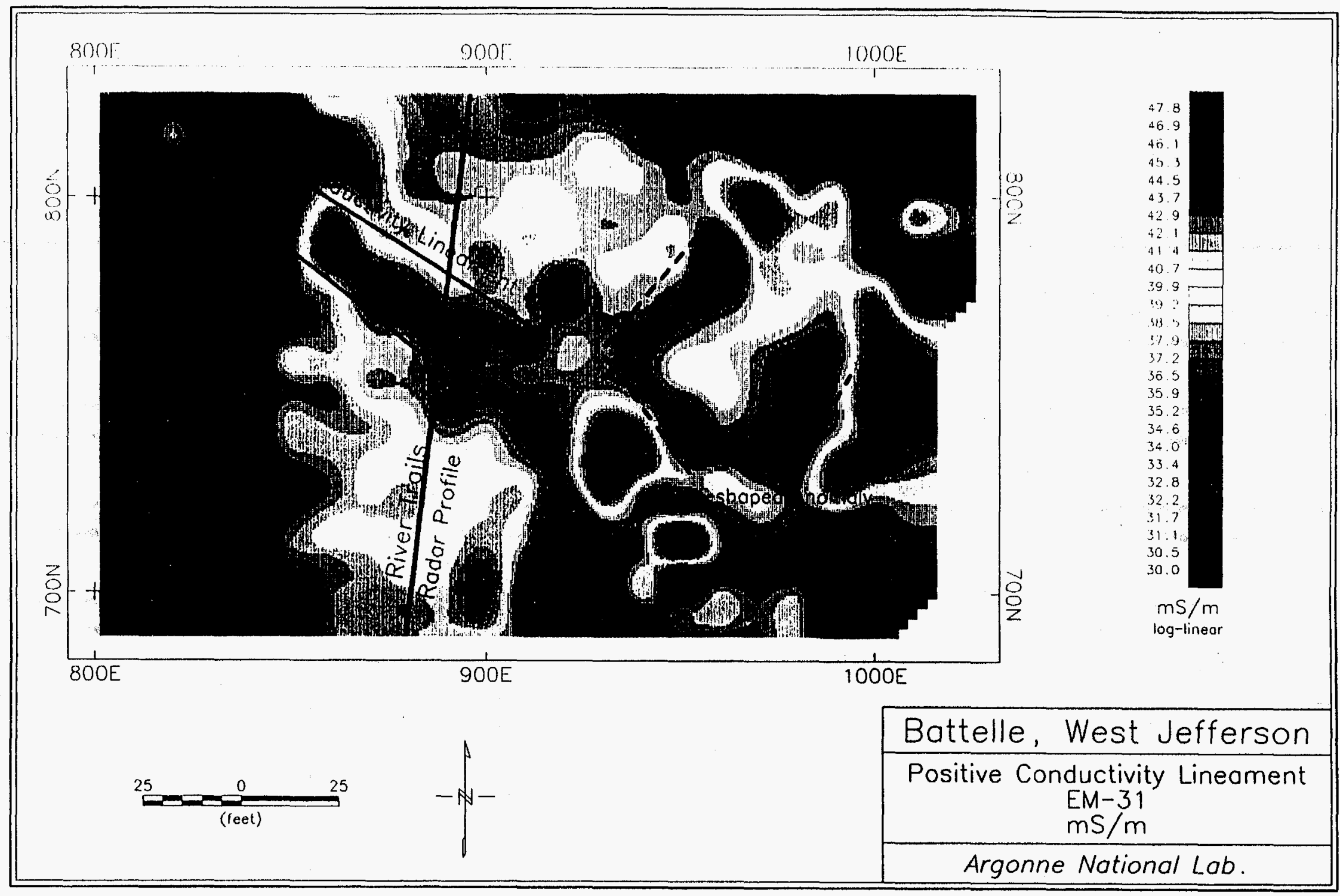

Figure 16. Map of Terrain Conductivity Anomalies Measured by the EM-31 in a Portion of the Southeast Subarea 


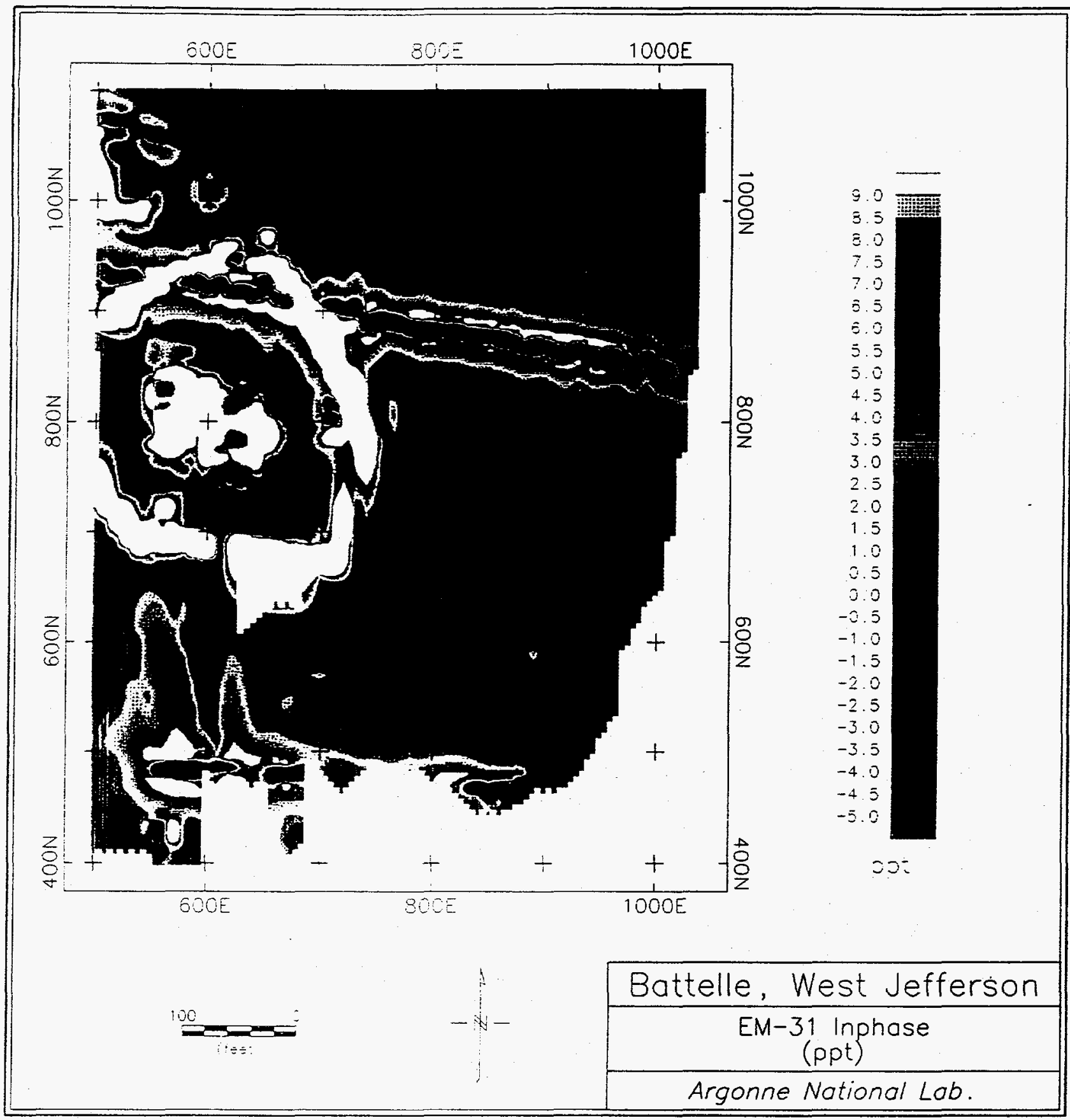

Figure 17. Map of In-Phase Conductivity Anomalies Measured by the EM-31 at Battelle West Jefferson 


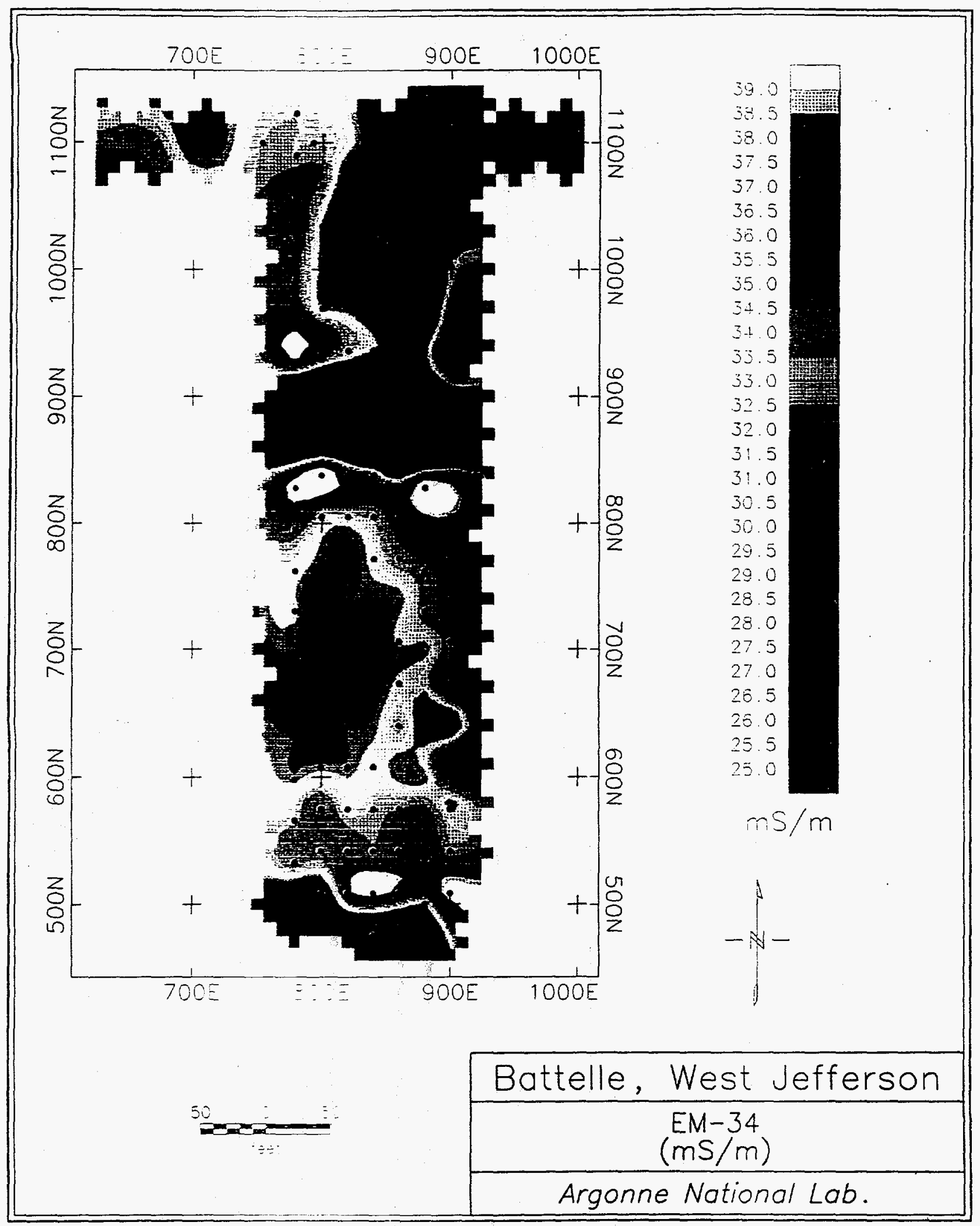

Figure 18. Map of Terrain Conductivity Anomalies Measured by the EM-34 at Battelle West Jefferson 
South of the pipeline, broad areas of conductivity highs and lows also correlate with relative lows and highs in the topography. Ground saturation and electrical conductivity increase within a topographically low region. 


\section{Vertical Electrical Soundings}

Electrical depth soundings were conducted at 12 locations on the floodplain (stations WJE1 through WJD7) and eight locations along the road crossing the dam (Figure 19). The earth layer models derived from the resistivity data are shown in Appendix A. In all cases, the resistivity of the bottom-most layer was fixed at $500 \mathrm{ohm}-\mathrm{m}$ to ensure model convergence.

The 12 resistivity soundings located on the floodplain were conducted along two N-S profiles, along $900 \mathrm{E}$ and $800 \mathrm{E}$. Station spacing was $100 \mathrm{ft}$ and each transect started at $1100 \mathrm{~N}$. Resistivity values ranged from 10 to $50 \mathrm{ohm}-\mathrm{m}$ in the upper 30 to $145 \mathrm{ft}$ (overburden). Distinct layers in the overburden material could not easily be correlated between soundings; however, depth to bedrock was generally consistent. Few estimates of bedrock resistivities are available, because in most cases, bedrock was modeled with a fixed value of $500 \mathrm{ohm}-\mathrm{m}$. In four earth resistivity models, however, bedrock resistivities ranged between 94 and $184 \mathrm{ohm}-\mathrm{m}$.

Along profile $900 \mathrm{E}$, the depth to bedrock generally increases from approximately $35 \mathrm{ft}$ in the north to about $145 \mathrm{ft}$ in the south. Bedrock depths along the $800 \mathrm{E}$ profile are estimated to be as much as $50 \mathrm{ft}$ deeper than those determined along profile $900 \mathrm{E}$. Noise produced by poor coupling between the electrodes and the soil can cause unrealistic estimates of depth.

Electrical resistivity stations WJCI0 to WJCI500 (Appendix A) show the resistivity-withdepth models for the six stations acquired along the road south of the dam. The stations were spaced every $100 \mathrm{ft}$ along a south-to-north profile, with the first station (WJCI0, Appendix A) located adjacent to the oil storage tanks. Resistivities for the overburden range from 16 to $60 \mathrm{ohm}-\mathrm{m}$ and from 200 to more than $400 \mathrm{ohm}-\mathrm{m}$ for the bedrock. An average depth of approximately $60 \mathrm{ft}$ was determined for the top of the bedrock, with the bedrock surface deepening to the north to approximately $85 \mathrm{ft}$.

Two resistivity soundings (Stations ND80 and ND0, Figure 19) were acquired on the northeast side of the dam, adjacent to the access road to the filter bed (Appendix A). Resistivities from 10 to $60 \mathrm{ohm}-\mathrm{m}$ are interpreted to be representative of the overburden and earthen fill for the dam. At ND80 and ND0, bedrock depths are 79 and $141 \mathrm{ft}$, respectively. These estimates correlate favorably with two deep borings drilled further south along the dam, which yielded bedrock depths of 108 and $85 \mathrm{ft}$.

A Schlumberger resistivity sounding was acquired along Rt. 142, with the north end of the electrode array located at the entrance gate to the main facility (Appendix A). The greater electrode spacings used by this array enabled sampling of a larger volume of the bedrock material than that used for the BOSS/Wenner arrays. A three-layer model is required to match the sounding data, with the upper two layers interpreted as overburden (16 and $75 \mathrm{ohm}-\mathrm{m}$ ). Depth to bedrock is approximately $139 \mathrm{ft}$. 


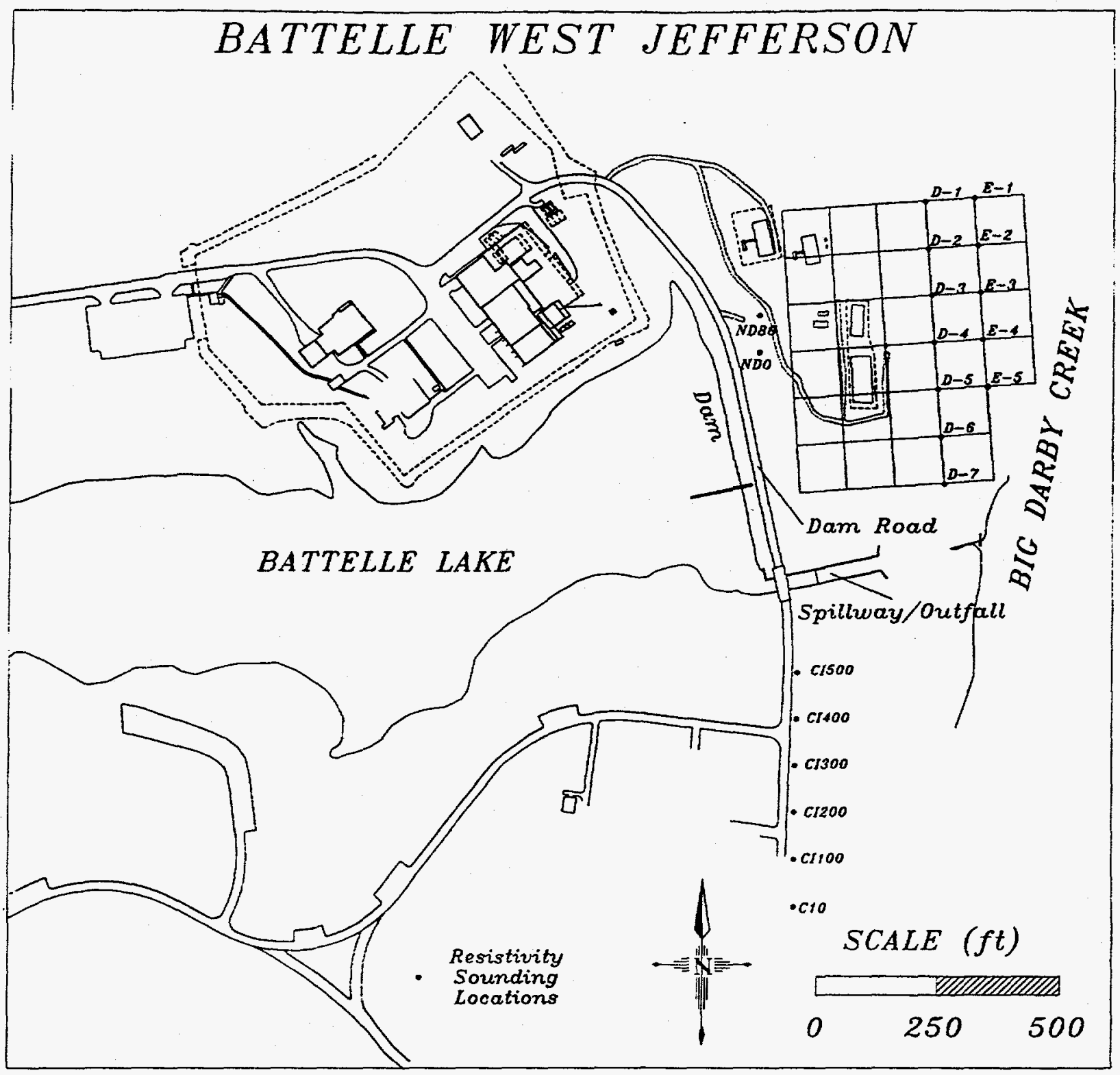

Figure 19. Map of Locations of Resistivity Soundings Conducted at Battelle West Jefferson 


\section{Ground-Penetrating Padar}

The primary objective of the GPR survey was to help to better understand the shallow stratigraphy in and around the retired filter bed area at BWJ. GPR also proved useful in helping to locate some buried anthropogenic features. The dense vegetation within most of the study area limited opportunities for GPR surveying. Profiles were collected in open areas, along existing paths, and along cleared and graded swaths in the more densely vegetated areas. In all, 21 GPR profiles were collected. The location of GPR profiles is shown in Figure 20, and a complete list of the corresponding grid coordinates is given in Appendix B.

Both the 100 - and $300-\mathrm{MHz}$ antennas, in a bistatic configuration, were tested at BWJ. The GPR profiles collected with the $300-\mathrm{MHz}$ antennas at a range setting of $250 \mathrm{~ns}$ provided the best data and were used over most of the site. The antennas were separated by a fixed distance of $4.5 \mathrm{ft}$, and profiles were collected in a continuous mode. An all-terrain vehicle was used to tow the antennas for most of the profiles; some profiles required that the antennas be pulled by hand in more densely vegetated areas. All of the profiles shown have been computer-processed with a vertical and horizontal low-pass, finite-impulse-response (FIR) boxcar filter. This filtering helps remove high-frequency noise and enhances structure at depth. Most of the profiles were also migrated by a hyperbolic summation method. Migrating the GPR data helps to remove diffracted reflectors and correct dipping layers. The data quality is quite variable across the entire site, most likely due to highly variable moisture and clay content in the upper 4-6 ft. The interpreted lithologies from the CPT data, which are discussed in Section 9, were used to help guide interpretation of the GPR data. On the basis of a correlation with CPT data, a two-way travel time of $12 \mathrm{~ns} / \mathrm{ft}$ is used in the following discussion. The maximum resolvable depth was 10-15 $\mathrm{ft}$ in most profiles.

Two GPR profiles were collected inside the fence of the current filter bed area at BWJ. GPR profile \#4 (Figure 21), collected from south to north, appears to image portions of the two retired filter beds, including underground piping and some dipping reflectors. The shallow, flatlying reflectors shown in Figure 21 correspond very closely with the locations of the retired filter beds in Figure 20. The interpreted pipes in the middle of the profile required some additional processing in order to better resolve the feature. After this profile was migrated, the hyperbolas resolved into at least two underground pipes. Locations and depths of these pipes, shown in Figure 21, are based on the migrated data. The steeply dipping, V-shaped reflector may be associated with excavation work, and the deeper reflectors may be natural in origin. The profile collected $20 \mathrm{ft}$ east of profile \#4 also images the pipes, the dipping $\mathrm{V}$-shaped reflector, and the deeper reflector. However, the shallow flat-lying reflector associated with the retired filter beds is absent, which corresponds with Figure 20. The pipes that are imaged inside the fence are not seen in the GPR profiles collected outside the fence.

The profiles from outside the fence were collected primarily to help gain a better understanding of the shallow stratigraphy at BWJ. At some locations outside the fence, uneven surface conditions and dense vegetation limited the effectiveness of GPR observations. However, 


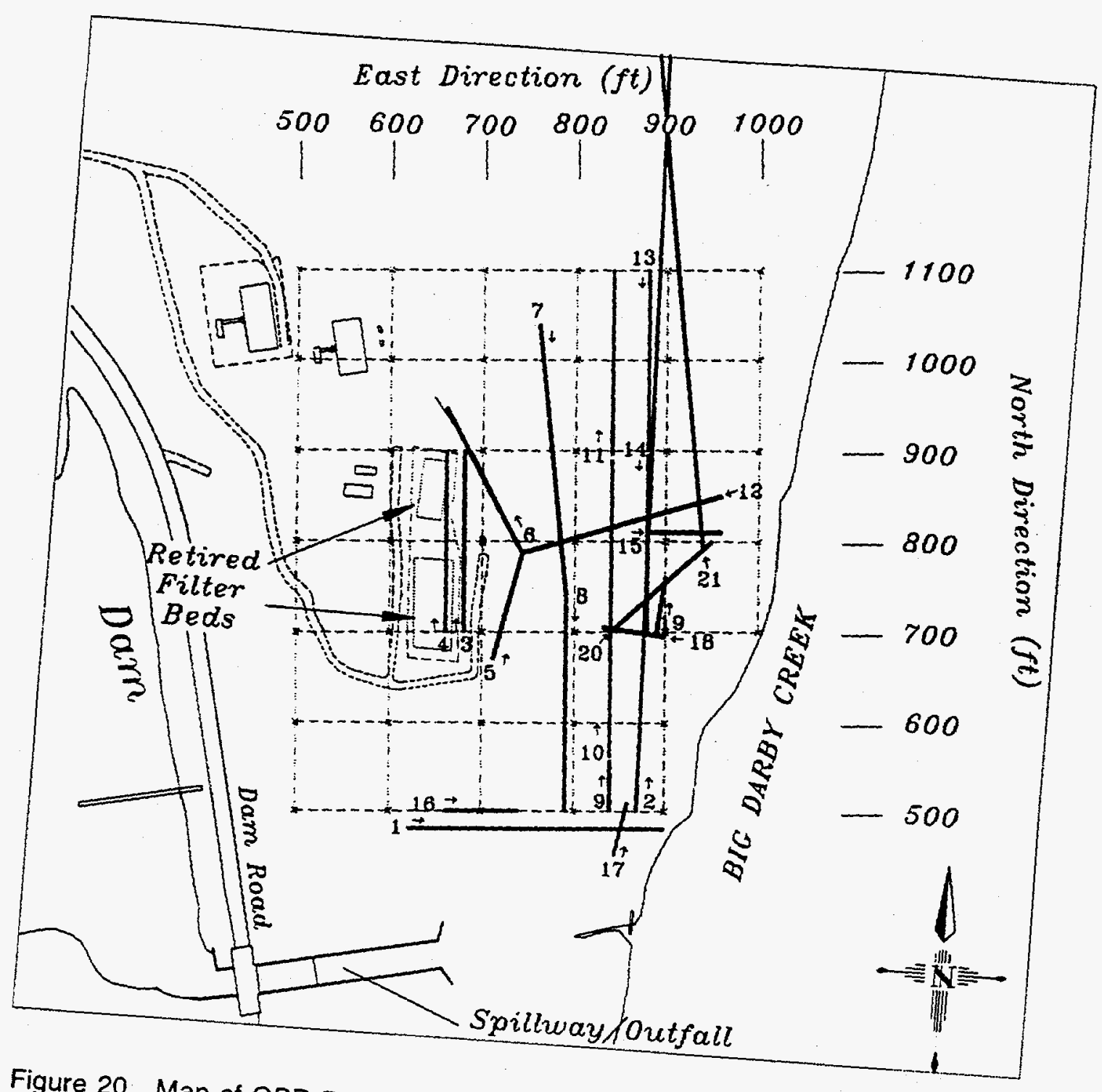

Figure 20: Map of GPR Profile Locations 


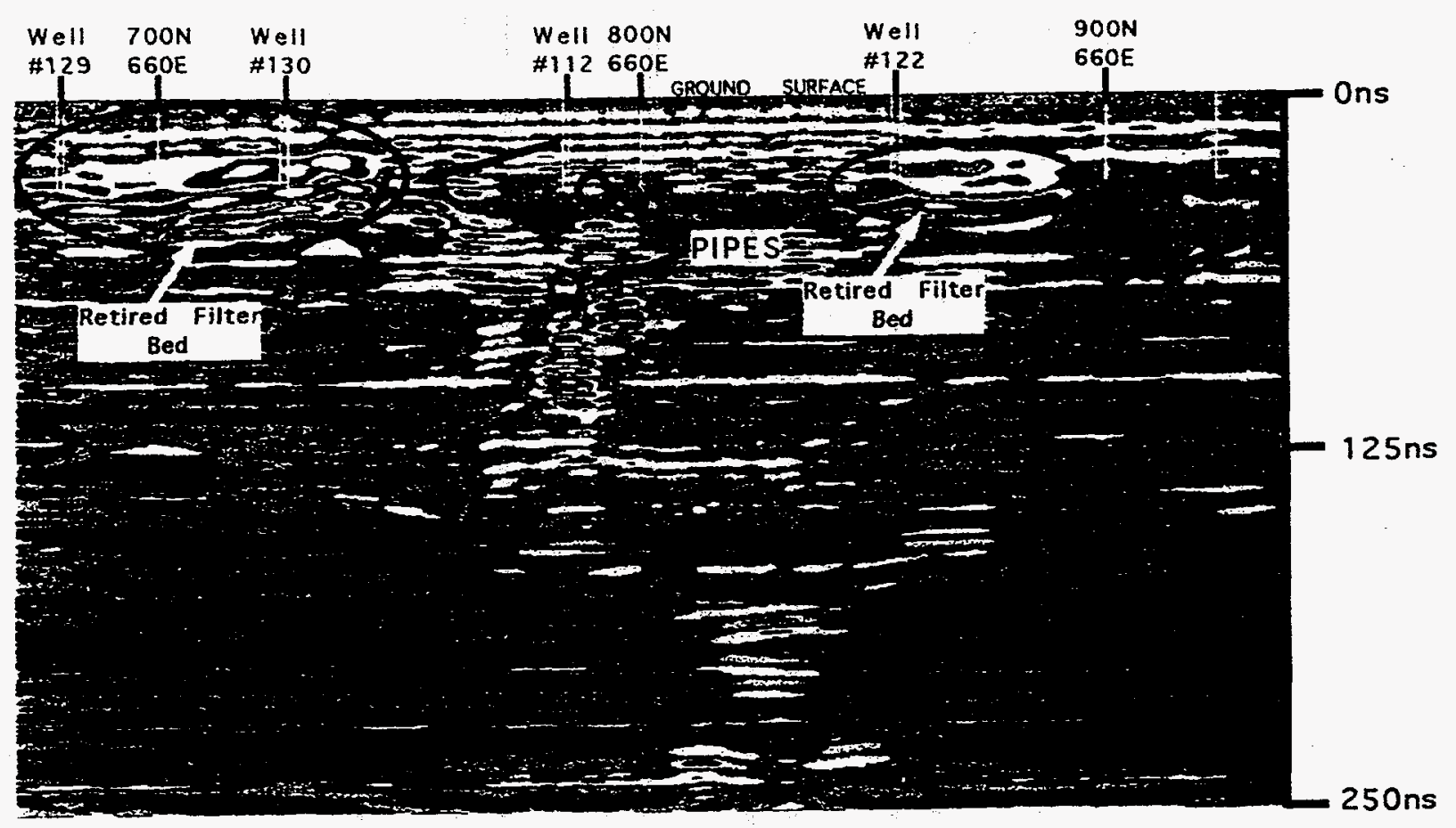

Figure 21. GPR Profile \#4 across Retired Filter Beds 
geologic structures of interest were imaged where surface conditions were favorable and where lithologic boundaries were sharp and well-defined. Profile \#16, which was collected from west to east at the southern boundary of the survey area, is shown in Figure 22. Between 50 and $150 \mathrm{~ns}$, bright yellow/orange reflectors are nearly continuous throughout the profile. The upper and lower boundaries are difficult to define with certainty. Accurate mapping of lithologies with GPR requires contacts of soils/rock with sharply contrasting electrical properties (i.e., electrical resistivity).

Figure 23 shows the first $400 \mathrm{ft}$ of profile \#2 (Figure 20). This profile, collected from south to north along the river trail road (roughly along $870 \mathrm{E}$ grid coordinates), crosses over four CPT sites (CPT-03 to CPT-06). After a low-pass FIR filter was applied and the profile was migrated, the reflectors became more resolvable. Similar to the profile shown in Figure 22, bright yellow/orange reflectors are observed in the middle of the profile. The top of this unit is not clearly defined, which is also most likely associated with the gradational nature of the contact. On the other hand, the bottom of this unit is more discernible in the first $200 \mathrm{ft}$ of the profile.

Some limited GPR work was performed in Area 1 in an effort to make comparisons with previous Battelle soil bore data. GPR work in Area 1 consisted of several profiles. One of the GPR profiles is presented in Appendix D. 


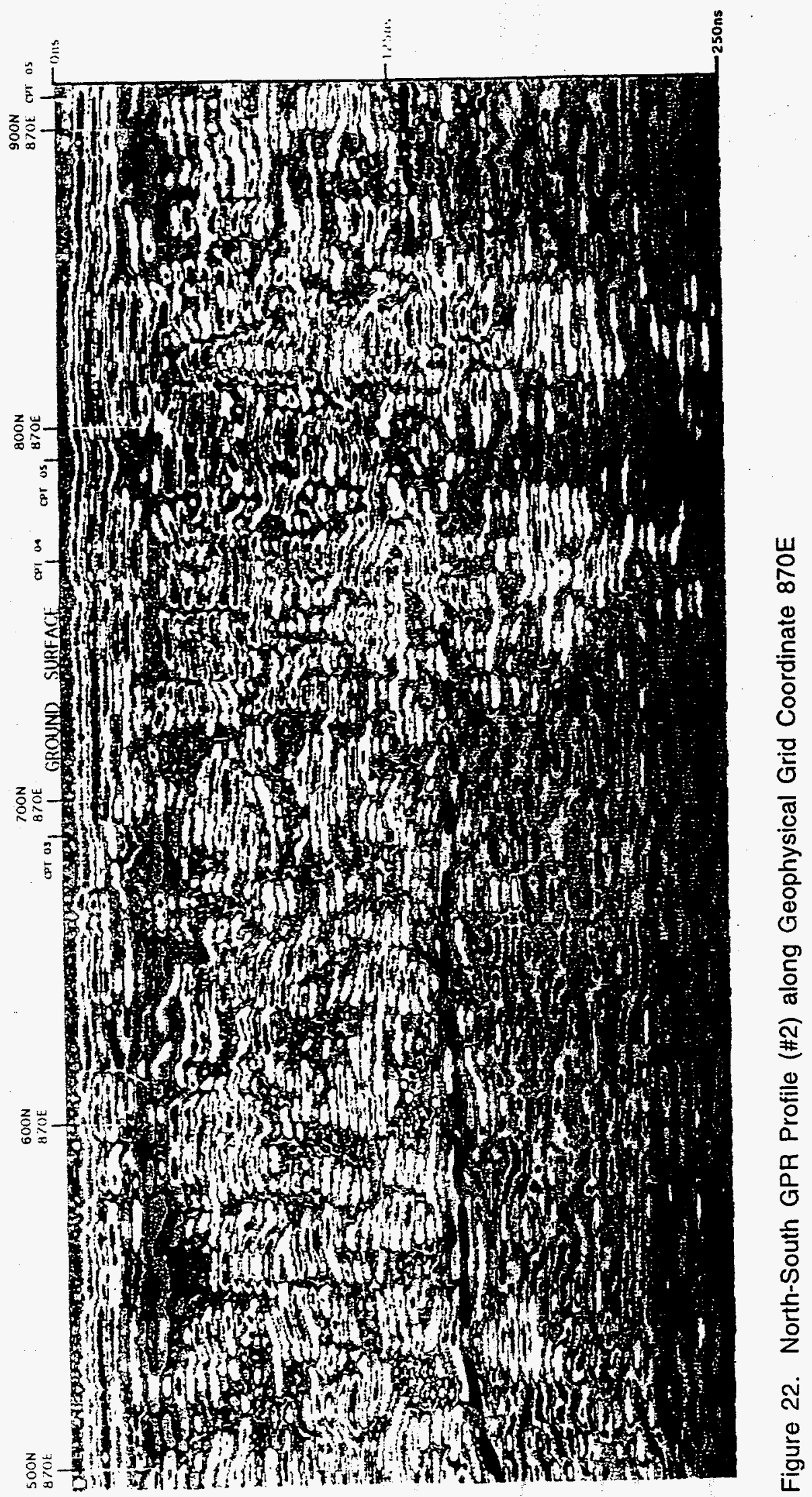




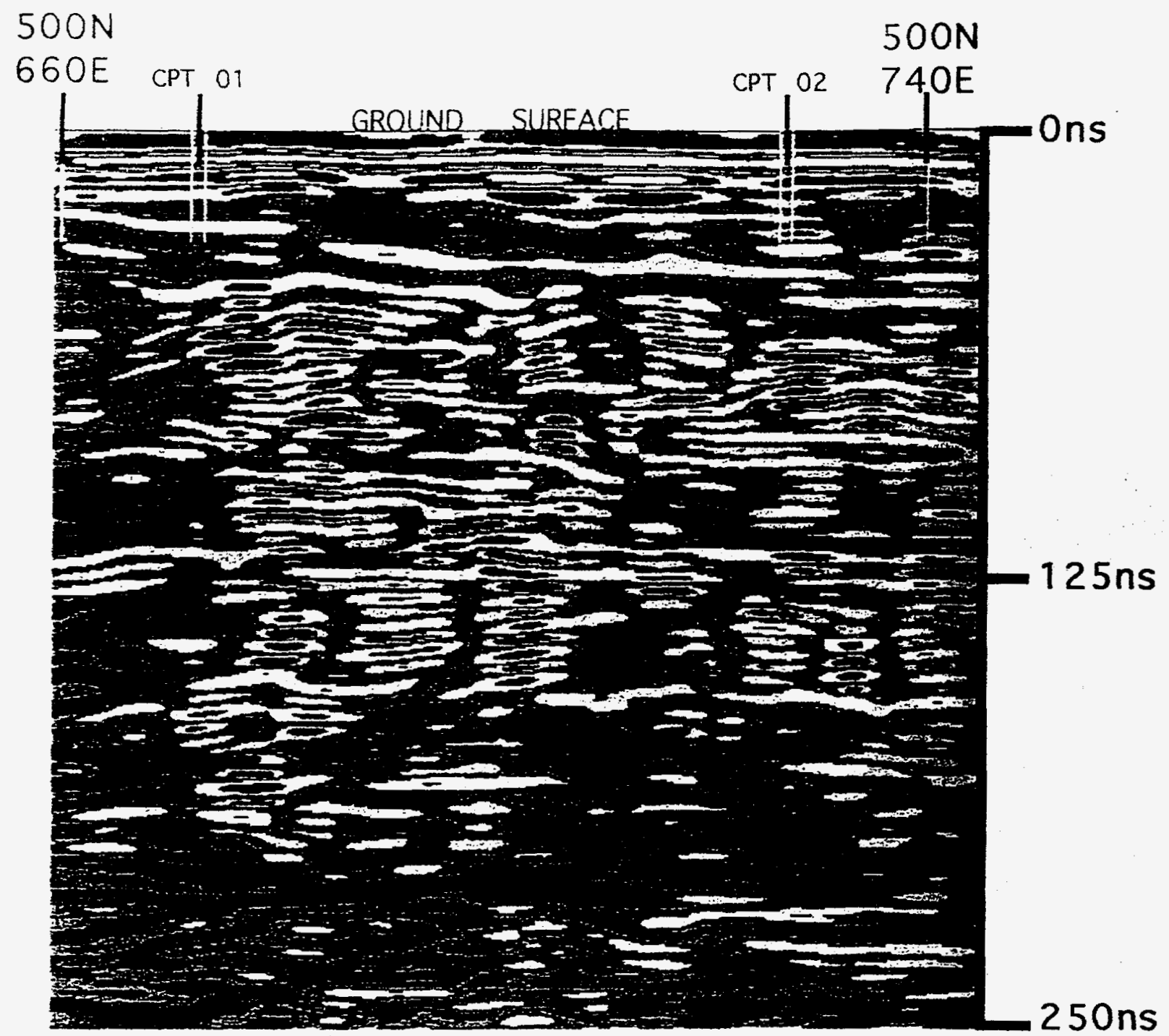

Figure 23. East-West GPR Profile (\#16) along Geophysical Grid Coordinate 500N 


\section{Seismic Refraction Profiling}

Seismic refraction profiles were recorded at six sites at BWJ. Four of the profiles (Lines 2, 3,4 , and 6 ) were located within or near the geophysical survey grid established around the retired filter beds (Figure 24); one profile (Line 1) was shot along the road crossing the Battelle Lake Dam, and one refraction station (Line 5) was sited along the south entrance road near Route 142. Figures 25-27 show the velocity and depth models obtained from the refraction data. Seismic velocities range from 6,234 to $7,744 \mathrm{ft} / \mathrm{s}$ for the overburden and 11,150 to $15,420 \mathrm{ft} / \mathrm{s}$ for the bedrock. These velocities are consistent with published results for glacial till and limestone in the western Ohio region (Wolfe and Richard 1992).

The velocity-depth structure determined from the refraction profile shot along the road crossing the Battelle Lake Dam (Line 1) is shown in Figure 25. The seismic line is oriented northto-south, with the northern end of the profile starting near the access road to the filter beds. A four-layer earth model is required to convert the measured travel times into velocities and depths. The upper two layers $(2,625$ and 3,609 ft/s) are interpreted to represent near-surface soils and earthen fill used for construction of the dam. The third layer, with a velocity of $7,723 \mathrm{ft} / \mathrm{s}$, is interpreted as glacial till. The fourth layer $(15,528 \mathrm{ft} / \mathrm{s})$ is interpreted as bedrock. At the northern end of the profile, a bedrock valley is identified beneath the Battelle Lake Dam. However, the bedrock depth at borehole DB-5 is approximately $60 \mathrm{ft}$ shallower than the seismic refraction bedrock surface (Figure 25), indicating that the velocity perturbations associated with the dam fill material were not successfully modeled. The bedrock depths at the southern end of the profile should be unaffected by dam fill material and suggest that the bedrock surface is relatively flat along this profile.

Seismic Line 2 was recorded on a NNW-SSE strike in the grassy area between the dam and the access road to the filter beds. Line 2 extends the velocity-depth information north from Line 1; the velocity-depth structure is shown in Figure 25. Velocities of 7,477 ft/s indicated for the overburden and 12,011 ft/s for the bedrock compare favorably with those obtained along refraction Line 1. The bedrock surface is relatively flat and averages 774 to $792 \mathrm{ft}$ in elevation.

Figures 26 and 27 are velocity-depth cross sections constructed from refraction lines 3,4 , and 6. These profiles were recorded on the floodplain. Line 4 is oriented north-to-south; Line 6 , south-to-north along grid coordinate $800 \mathrm{E}$; and Line 3 , west-to-east. Seismic velocities in this area range from 6,014 to $7,477 \mathrm{ft} / \mathrm{s}$ for the overburden and from 12,418 to $13,285 \mathrm{ft} / \mathrm{s}$ for the underlying bedrock. Both Line 4 and Line 6 indicate that the bedrock surface slopes toward the south, changing in elevation from approximately $820 \mathrm{ft}$ on the north to $760-770 \mathrm{ft}$ at the south end of each profile. At the intersections between Line 3 and Lines 4 and 6 (Figure 26), bedrock depths differ by less than $20 \mathrm{ft}$. The bedrock surface is approximately $33 \mathrm{ft}$ higher in the northwest part of the survey grid than that observed along refraction Line 2 to the west.

The velocity-depth structure determined from refraction Line 5 (south entrance road) is shown in Figure 27. Surface elevations and grid coordinates are unavailable for this profile because it was obtained outside of the geophysical survey area. This refraction information was 


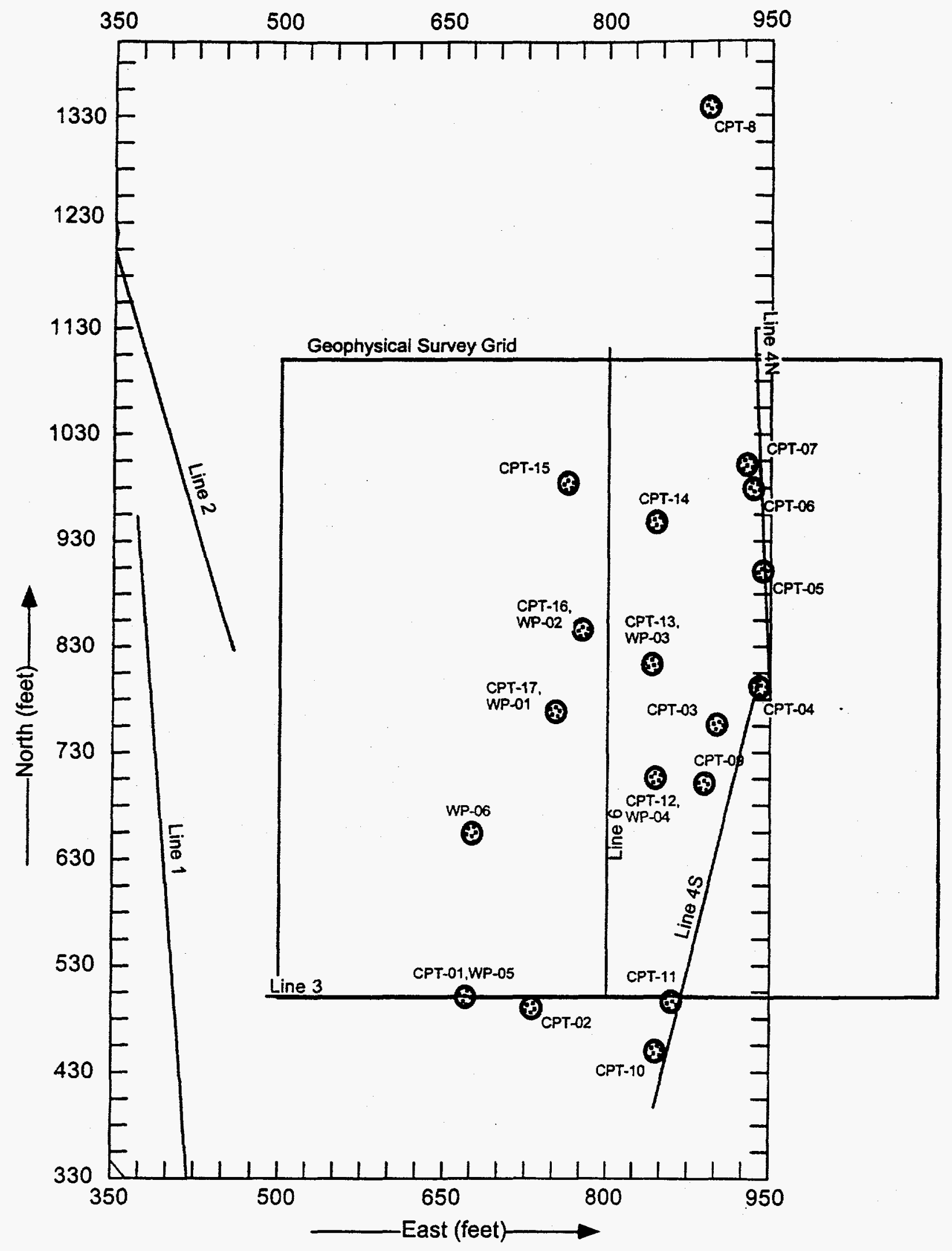

Figure 24. Map Showing Locations of Seismic Refraction Profiles, CPT and Piezometer Sites 
North

(951, 370)

Line 1

South

$(330,420)$

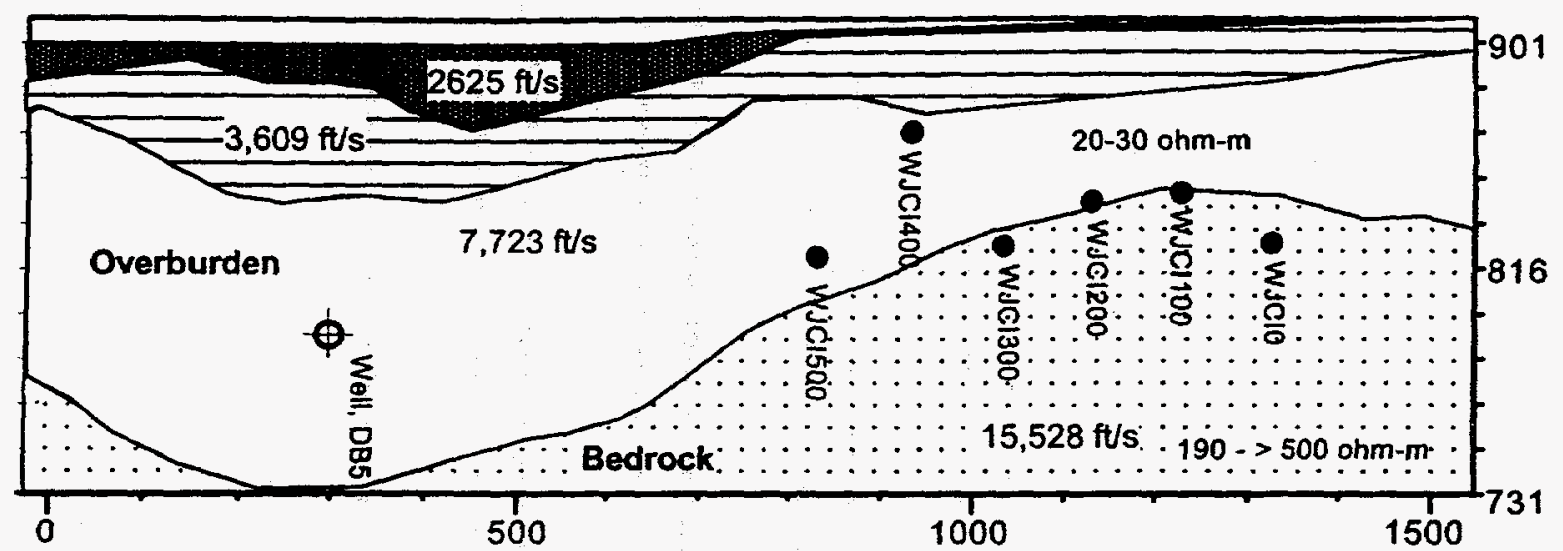

North

$(1200,350)$

Line 2

South

(827, 458)

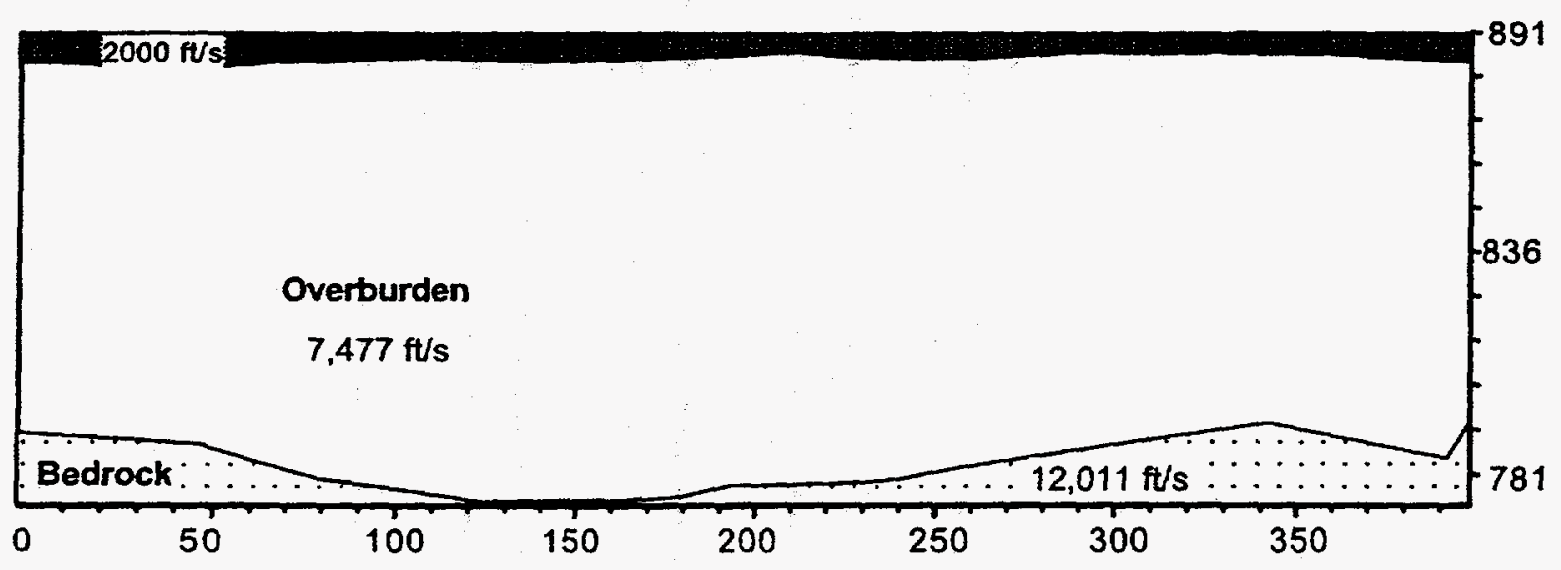

Figure 25. Results of Modeling along Seismic Lines 1 and 2 
West

$(500,490)$
Line 3

East

$(500,900)$

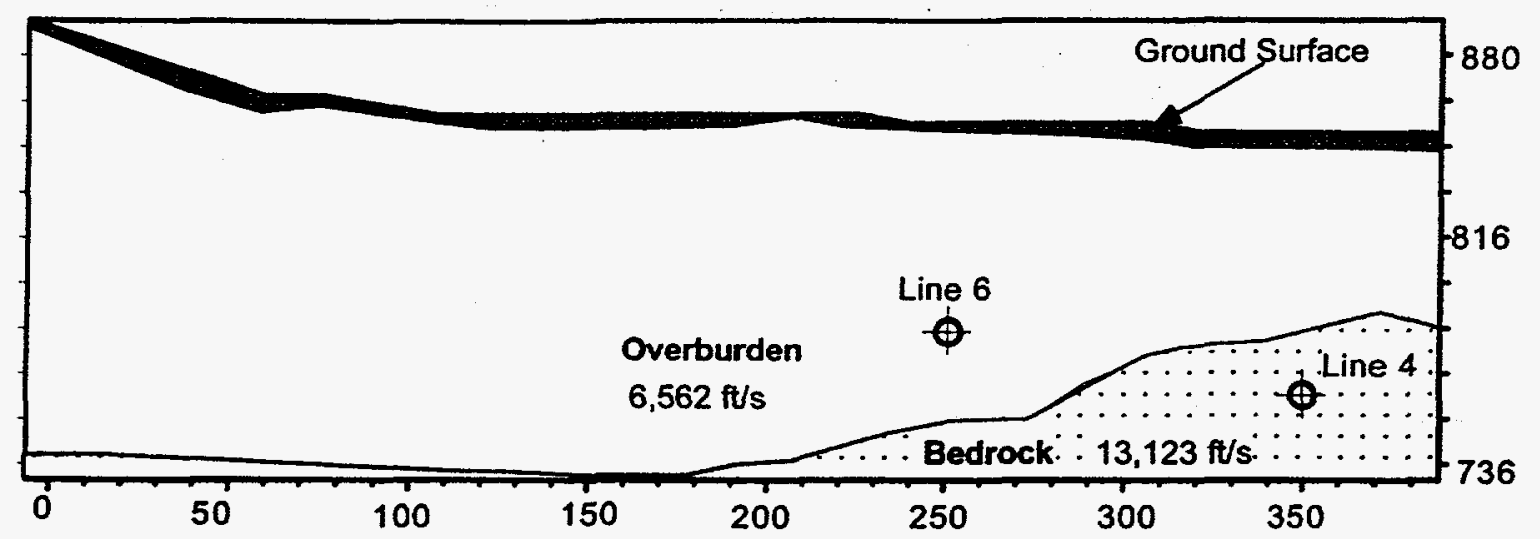

North

(1125, 935)

Line 4

South

$(801,950)$

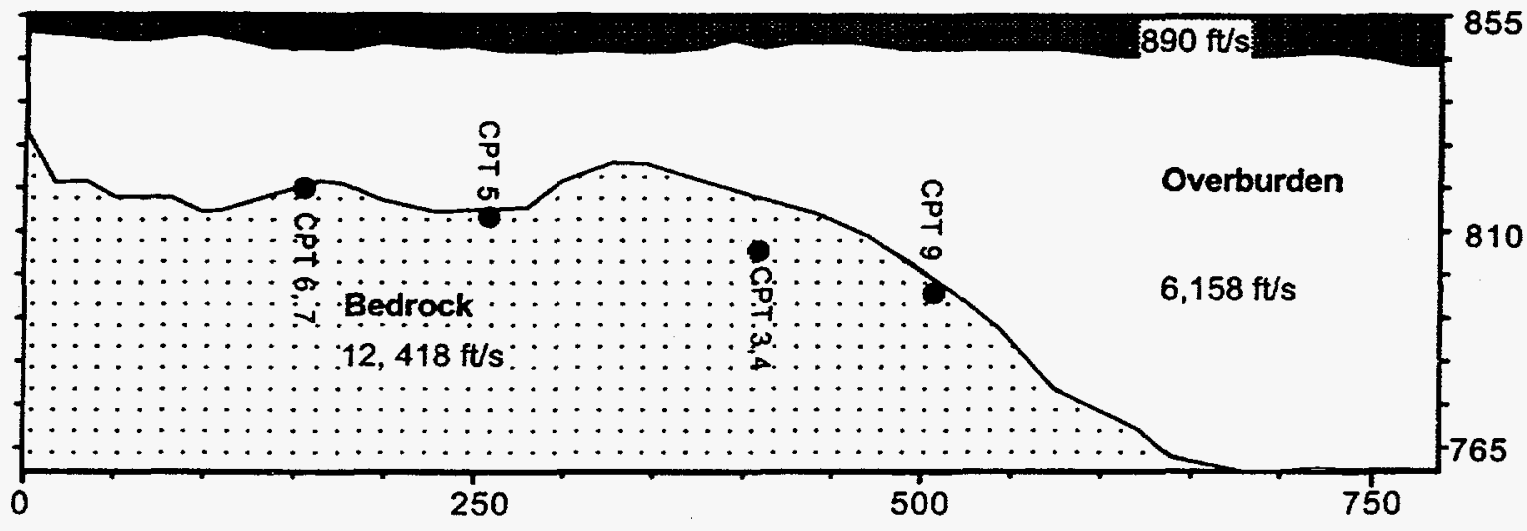

Figure 26. Results of Modeling along Seismic Lines 3 and 4 
East

Line 5

West

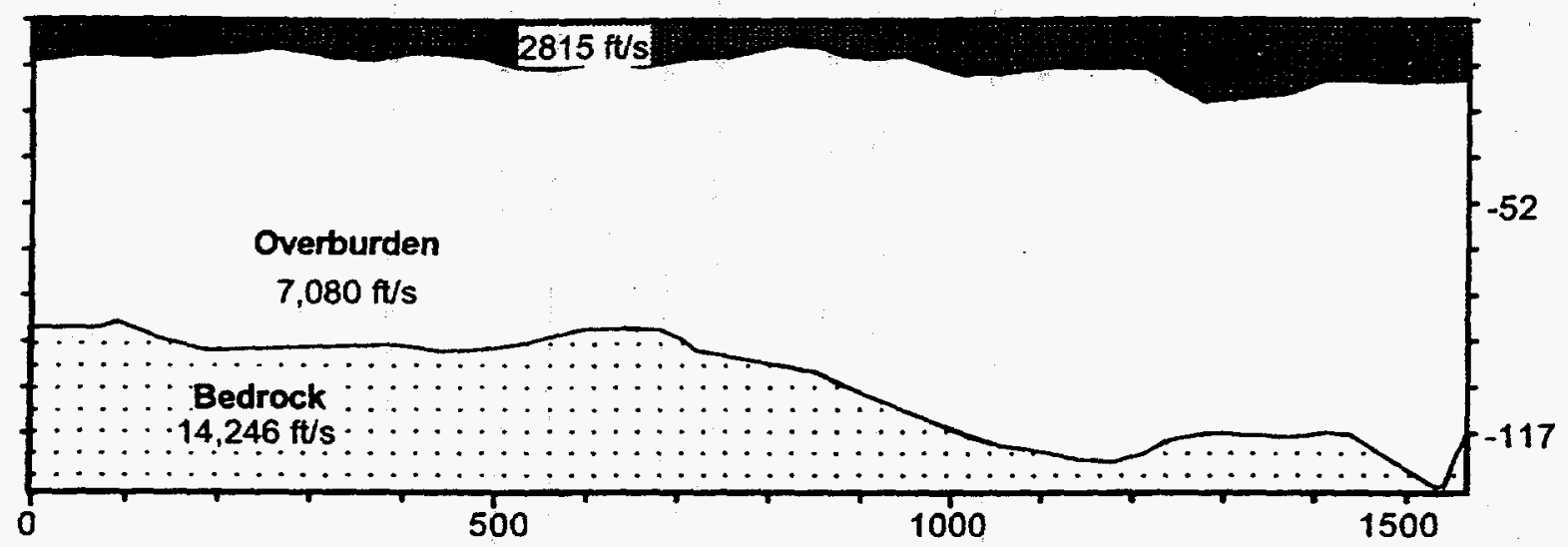

South

$(500,800)$

Line 6

North

$(1100,800)$

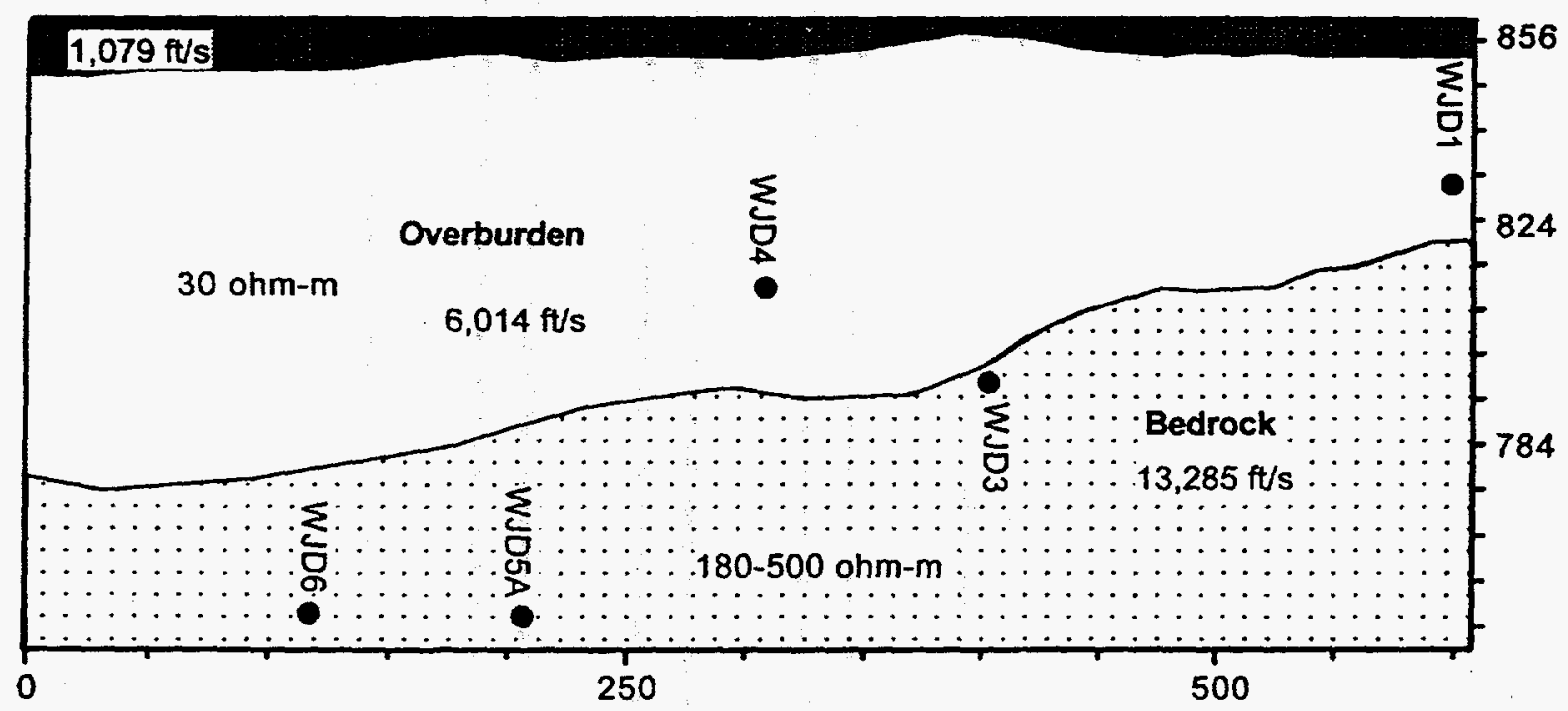

Figure 27. Results of Modeling along Seismic Lines 5 and 6 
acquired along the south entrance road to BWJ and is useful in that it provides a more regional definition of the velocity and depth/thickness for the bedrock and overburden material. A threelayer model was used to convert the refraction information into velocities and thicknesses. Bedrock velocities ranged from 13,000 to $16,000 \mathrm{ft} / \mathrm{s}$, with a mean velocity of $14,246 \mathrm{ft} / \mathrm{s}$ used in the model. For the overburden, velocities ranged from 6,171 to $7,874 \mathrm{ft} / \mathrm{s}$, and a mean velocity of $7,080 \mathrm{ft} / \mathrm{s}$ was used to invert the refraction data. The bedrock surface deepens to the west, changing from approximately $92 \mathrm{ft}$ in depth at the east end of the profile to a maximum depth of $117 \mathrm{ft}$ toward the west end of the profile. 


\section{Cone Penetrometer Testing}

Seventeen CPT soundings were performed along three north-to-south transects in the floodplain of Big Darby Creek just east of the retired filter beds. The locations of the CPT soundings are indicated in Figure 24 and in Table 3; they are labeled CPT01 through CPT17. The soundings were performed over a three-day period, and decisions about the CPT coordinates and the investigation depths were made by the project team in real time. Soundings were located where geophysical results, principally the ground-penetrating radar, suggested that coarser, unconsolidated units might be more developed, and where it was necessary to better understand the geologic and hydrogeologic frameworks.

\section{Table 3 CPT Locations and Elevations at West Jefferson Filter Bed Area}

\begin{tabular}{|c|c|c|c|c|}
\hline \multirow[b]{2}{*}{ CPT I.D } & \multicolumn{2}{|c|}{ Grid Coordinates } & \multicolumn{2}{|c|}{ Ground Surface } \\
\hline & North & East & $\begin{array}{l}\text { Elevation } \\
\text { (MSL, ft) }\end{array}$ & $\begin{array}{l}\text { Total Depth } \\
\text { Below Ground } \\
\text { Surface (ft) }\end{array}$ \\
\hline 01 & 499.41 & 670.94 & 859.48 & 45.8 \\
\hline 02 & 495.62 & 729.57 & 859.69 & 77.9 \\
\hline 03 & 758.37 & 901.44 & 859.61 & $52.8^{\mathrm{a}}$ \\
\hline $04^{b}$ & 790 & 941 & -859 & $51.9^{\mathrm{a}}$ \\
\hline 05 & 902.62 & 947.30 & 859.37 & $41.9^{a}$ \\
\hline 06 & 981.66 & 932.32 & 859.49 & $37.1^{\mathrm{a}}$ \\
\hline 07 & 1000.27 & 926.21 & 859.39 & $35.1^{\mathrm{a}}$ \\
\hline 08 & 1337.01 & 892.42 & 859.91 & $19.8^{a}$ \\
\hline 09 & 700.06 & 890.83 & 860.65 & $57.7^{\mathrm{a}}$ \\
\hline 10 & 450.36 & 845.67 & 858.34 & 74.3 \\
\hline 11 & 496.18 & 860.62 & 858.40 & 58.0 \\
\hline 12 & 706.59 & 845.91 & 861.82 & 50.0 \\
\hline 13 & 815.81 & 841.35 & 856.72 & 51.0 \\
\hline 14 & 949.80 & 844.92 & 857.26 & $44.2^{a}$ \\
\hline 15 & 985.48 & 763.49 & 857.72 & 22.7 \\
\hline 16 & 851.69 & 774.81 & 857.49 & 37.1 \\
\hline 17 & 768.23 & 750.14 & 860.43 & 50.0 \\
\hline
\end{tabular}

a Field Interpretations of Refusal on Bedrock.

- CPT-04 was not surveyed by contracted land surveyor. ANL measured location based on existing survey grid and estimated elevation from other nearby CPT locations.

The primary objectives of the CPT sounding work at the BWJ site were to determine the optimal placement and target depth for the wellpoints and to provide ground truth to the geophysical surveys. Relevant factors that had to be carefully considered while performing this intrusive investigative task included concerns about the proximity of the subject area to a Federal 
Scenic River, access limitations with the CPT truck, and a need for streamlined project scope and cost. With respect to the nearby Federal Scenic River, the scope of the nonintrusive and intrusive investigations addressed the concern about preservation of existing vegetation, to the greatest extent possible, and CPT soundings and wells were placed at appropriate setback distances from the Big Darby Creek. Access through the heavily wooded areas of the floodplain was provided by means of selective removal of younger growth trees, less than 6 in. in diameter, in conjunction with limited grading. Access was limited to that existing along the river trail road and to three north-south-trending transects that were utilized to collect supplementary GPR data for establishing the CPT locations in real time. Grading was necessary to remove loose ground litter prior to GPR data collection and to remove terrain obstacles to the CPT truck. Grading, performed with a bobcat and a D5 Caterpillar bulldozer, was done while GPR and CPT work were being performed elsewhere on the site.

The scope of the intrusive investigation was streamlined by utilizing the CPT electrical logging information, tip resistance, sleeve resistance, pore pressure, and soil resistivity curves to establish stratigraphic correlations between CPT holes. As the CPT logging results between holes became available, preliminary stratigraphic interpretations were made in the field to guide the location and depth of the succeeding CPT locations. Figure 28 illustrates the proposed correspondence between stratigraphic correlations established at CPT17 with a previously drilled Battelle shallow soil bore, R 144, located inside the fenced retired filter bed area. Good correlation does exist between the electronic logging data at CPT17 and the soil descriptions from that shallow bore. The distance between the CPT 17 control hole and R144 is approximately $70 \mathrm{ft}$. Although the CPT data have been helpful for understanding the stratigraphy, significant enhancements can be made by conducting some deep soil bores and obtaining soil descriptions as improved CPT control points.

On the basis of electric logging data, available subsurface information, and other published literature on CPT responses, the unconsolidated overburden materials were tentatively subdivided into three units, in descending order: (1) an alluvial/fluvial layer consisting of silty clay to silt (CL-ML according to the Unified Soil Classification System), (2) an outwash layer consisting of silty sand (SM) to sand, and (3) a cohesive layer probably consisting of till. The silty clay to silt layer corresponds to the Medway Series soils that were mapped at the BWJ floodplain area (USDA 1981). In Madison County, those Medway Series soils may also include an underlying silty sand or clayey sand (SM or SC) layer at depths of 3 to $5 \mathrm{ft}$.

Results of this investigation indicate that the recent alluvial/fluvial silty clay and an underlying sand drape over approximately $12 \mathrm{ft}$ of relief on the till surface. The silty clay and the underlying sand unit are continuous in the study area. The sand layer, in particular, was scrutinized to detect thickening trends or areas of enhanced transmissivity. It ranges from 2 to $5 \mathrm{ft}$ in thickness, based on careful scrutiny of the Battelle soil descriptions. At some Battelle bore locations in the retired filter bed area, it appears that further confirmation of the soil stratigraphy may be warranted to better understand the conditions. Figure 9 is a geologic profile, based on Battelle soil bore data, that illustrates the distribution of granular deposits that underlie the retired 


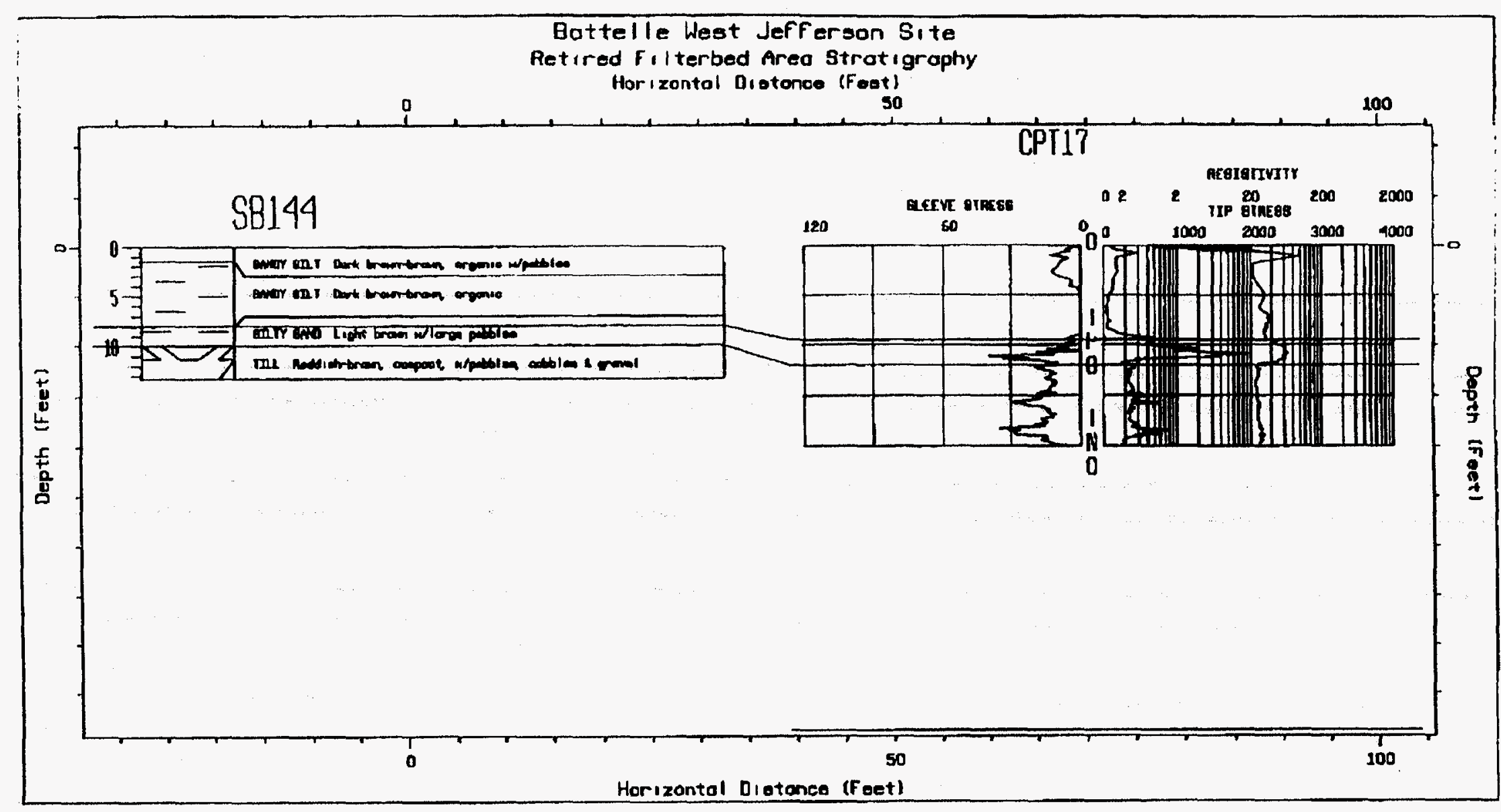

Figure 28. Comparison of Geologic Log from Borehole R144 and CPT17 Electronic Log 
filter bed area. Analysis of the electrical logging data was fully exploited as a mechanism to recognize subtle trends regarding the thickness of the sand in the CPT holes; however, those possible trends require confirmation with additional soil sampling descriptions. The top of the glacial till in the floodplain area was previously reported in a number of shallow Battelle soil borings, at depths of approximately $12 \mathrm{ft}$. A structure contour map of the top of the till, based primarily on the CPT correlations, is shown in Figure 29. The surface of the till declines eastward, and a broad ridge of low relief extends east to west. Analysis of the CPT logging curve correlations and characteristics also shows that those deposits and one or more subunits thicken in a south-southeast direction.

Initially, CPT soundings were performed along the river trail road; these involved eight holes (CPT03 through CPT08, CPT10 and CPT11) that penetrated between 78 and $20 \mathrm{ft}$ of unconsolidated overburden materials. Another two CPT soundings, CPT01 and CPT02, were performed just east of the Battelle Lake Dam and reached depths of 46 and $78 \mathrm{ft}$, respectively. The continuous logging curve data from CPT01 and CPT02 are shown as a geologic profile on Figure 30; this profile corresponds with GPR line \#16 (Figure 23). Table 4 provides depths to lithologies of all of the CPT soundings. Figure 31 illustrates the geologic profile, utilizing the electric logging curve data from CPT03 through CPT06 along the frontage trail road. This profile corresponds with the transect of GPR line \#4 (Figure 22). The geologic profiles provided in this report can only represent a generalized interpretation of the subsurface geology at this time. More detailed interpretation of the CPT records cannot be performed until some selected deep soil bores are conducted at some of the CPT holes. Additional soil bore data would facilitate detailed delineation of stratigraphic units by enabling the electronic responses to be calibrated with direct observations of the subsurface geology.

Some of the CPT holes were terminated because the sensor tip encountered refusal conditions (i.e., bedrock or, alternatively, very coarse unconsolidated materials). Evaluation of the nonintrusive geophysical survey data supports the conclusion that the observed refusal depths coincide with the top of bedrock. (Note that six out of the eight of the CPT holes along this traverse encountered refusal). An interpreted north-south geologic profile is provided as Figure $32 \mathrm{a}$ and $\mathrm{b}$. The profile is an interpretation of the CPT data and portrays a generalized view of the stratigraphy. Numerous localized changes were recognized in the CPT data, but they cannot be confidently interpreted on the basis of the available subsurface geologic information. This diagram does illustrate that the bedrock surface noticeably declines toward the south, with approximately $32 \mathrm{ft}$ of relief between CPT08 and CPT03. 


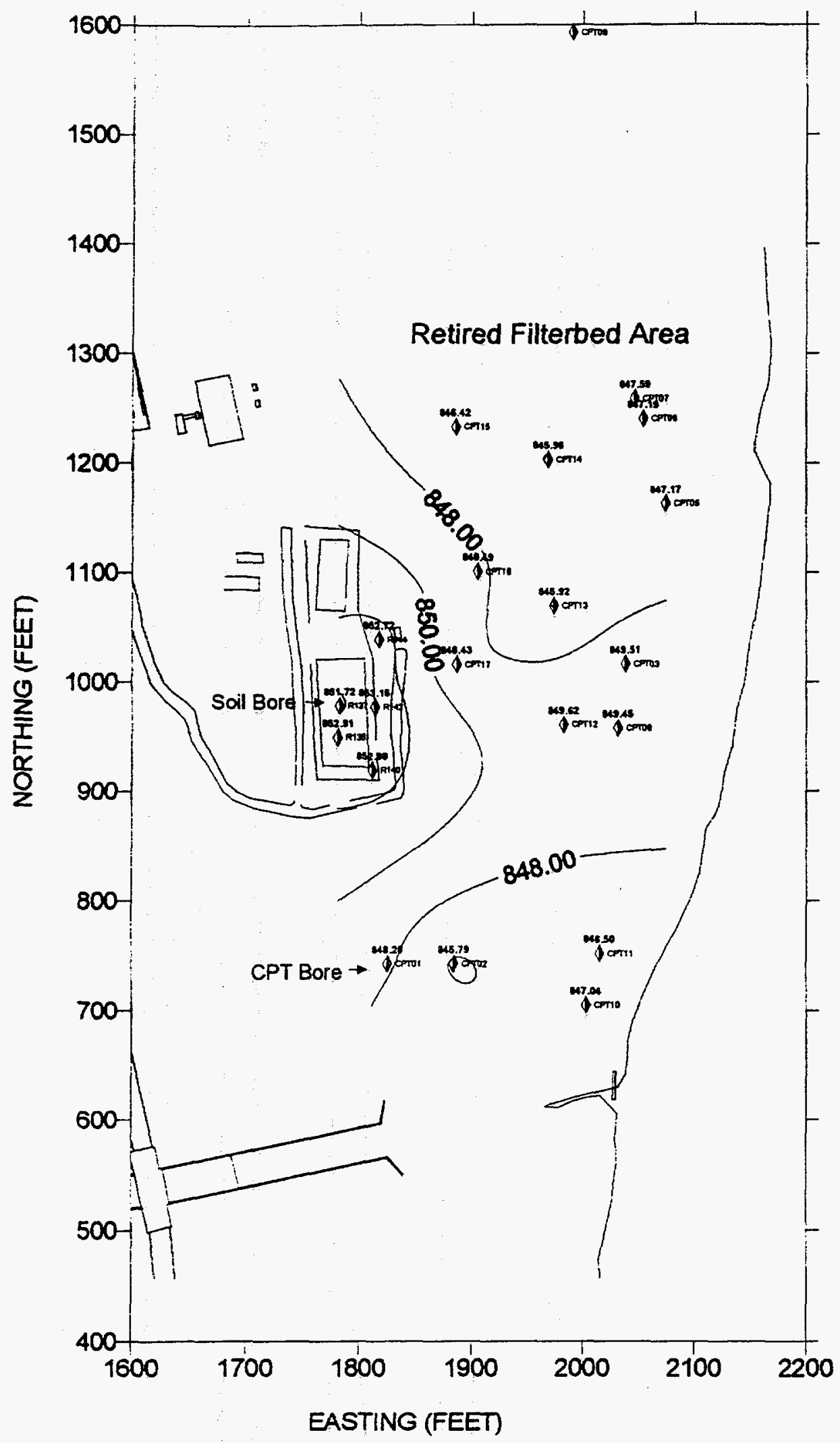

Figure 29. Structural Contour Map of the Top of the Glacial Till 
Table 4. Information from Cone Penetrometer Soundings

\begin{tabular}{cccccc}
\hline Location & $\begin{array}{c}\text { Surface } \\
\text { Elevation TOC } \\
(\mathrm{ft}, \mathrm{MSL})\end{array}$ & $\begin{array}{c}\text { Top of Sand } \\
\text { Unit Elevation } \\
(\mathrm{ft})\end{array}$ & $\begin{array}{c}\text { Top of Till Unit } \\
\text { Elevation } \\
(\mathrm{ft})\end{array}$ & $\begin{array}{c}\text { Top of Clay } \\
\text { Unit Elevation } \\
(\mathrm{ft})\end{array}$ & $\begin{array}{c}\text { Bottom Hole } \\
\text { Elevation } \\
(\mathrm{ft})\end{array}$ \\
\hline CPT01 & 859.48 & 853.08 & 848.28 & nde & 813.68 \\
CPT02 & 859.69 & 851.09 & 845.79 & 811.09 & 781.79 \\
CPT03 & 859.61 & 852.81 & 849.51 & absent & 806.81 \\
CPT04 & 859.44 & & 8 & a & 807.1 \\
CPT05 & 859.37 & 849.37 & 847.17 & 820.67 & 817.47 \\
CPT06 & 859.49 & 850.19 & 847.19 & 826.09 & 822.39 \\
CPT07 & 859.39 & 850.39 & 847.59 & 826.79 & 824.29 \\
CPT08 & 859.92 & 851.62 & 846.72 & absent & 840.12 \\
CPT09 & 860.65 & 852.45 & 849.45 & 814.65 & 802.95 \\
CPT10 & 858.34 & 849.94 & 847.04 & 809.54 & 784.04 \\
CPT11 & 858.4 & 849.8 & 846.5 & 809.2 & 800.4 \\
CPT12 & 861.82 & 852.52 & 849.62 & 814.32 & 811.82 \\
CPT13 & 856.72 & 849.72 & 845.92 & 813.12 & 805.72 \\
CPT14 & 857.26 & 848.76 & 845.96 & 818.26 & 813.06 \\
CPT15 & 857.72 & 849.32 & 846.42 & absent & 835.02 \\
CPT16 & 859.69 & 852.69 & 848.49 & nde & 822.59 \\
CPT17 & 848.28 & 850.93 & 848.43 & 811.63 & 810.43 \\
\hline
\end{tabular}

${ }^{a}$ Elevation was measured, but coordinates for this CPT hole are estimated.

Three additional CPT soundings were performed along a north-south transect at the 845 east coordinate line and on a north-south transect along the 750 to 780 east coordinate line. The CPT soundings along the 845 east line included CPT 12 through CPT 14 and ranged in depth from 44 to $51 \mathrm{ft}$. The other transect, involving CPT15 through CPT17, ranged from 23 to $50 \mathrm{ft}$ in depth. At CPT15, refusal was encountered at a depth of approximately $23 \mathrm{ft}$. 


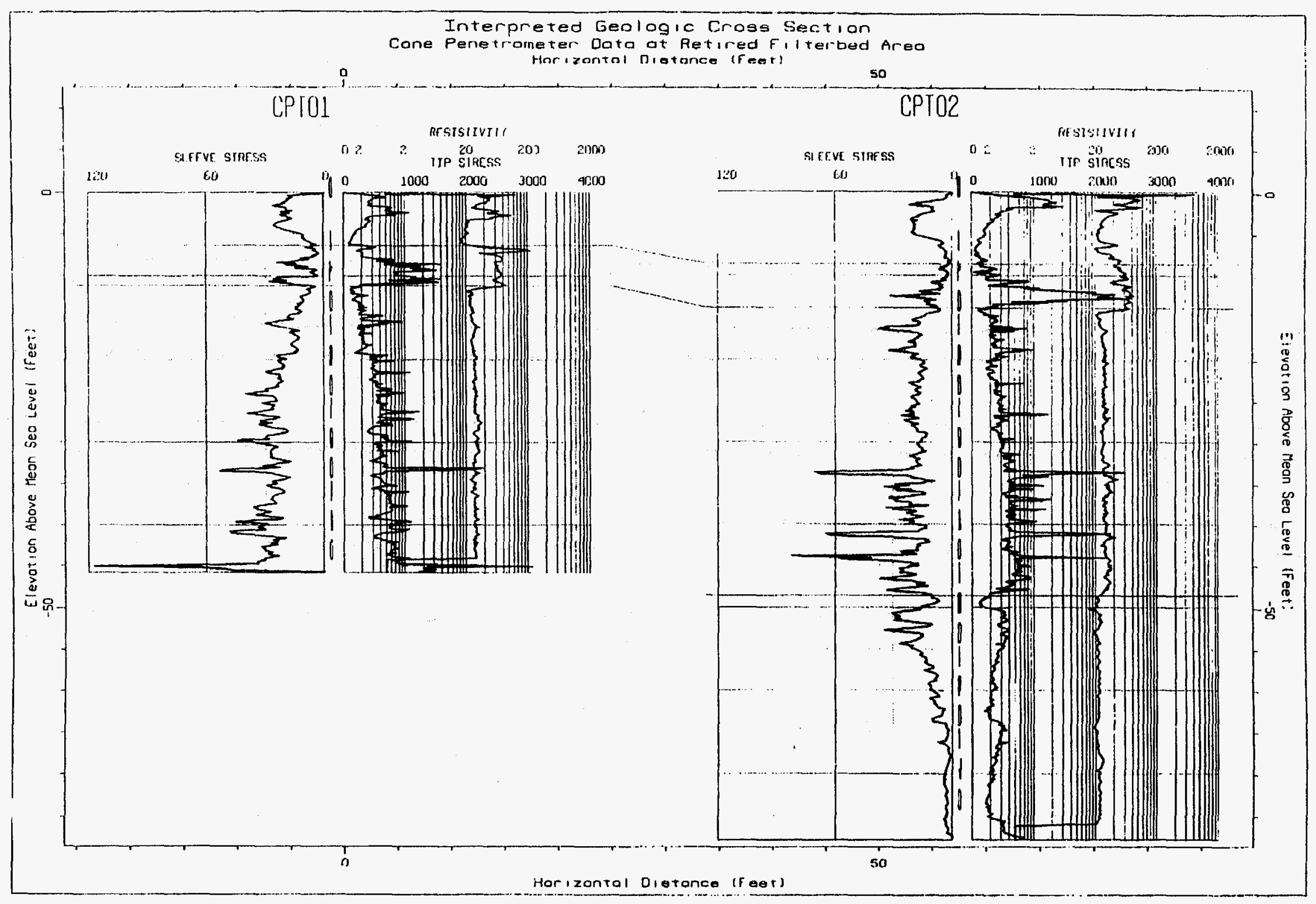

Figure 30. Correlation of CPT Electric Log Data from CPT01 and CPT02 


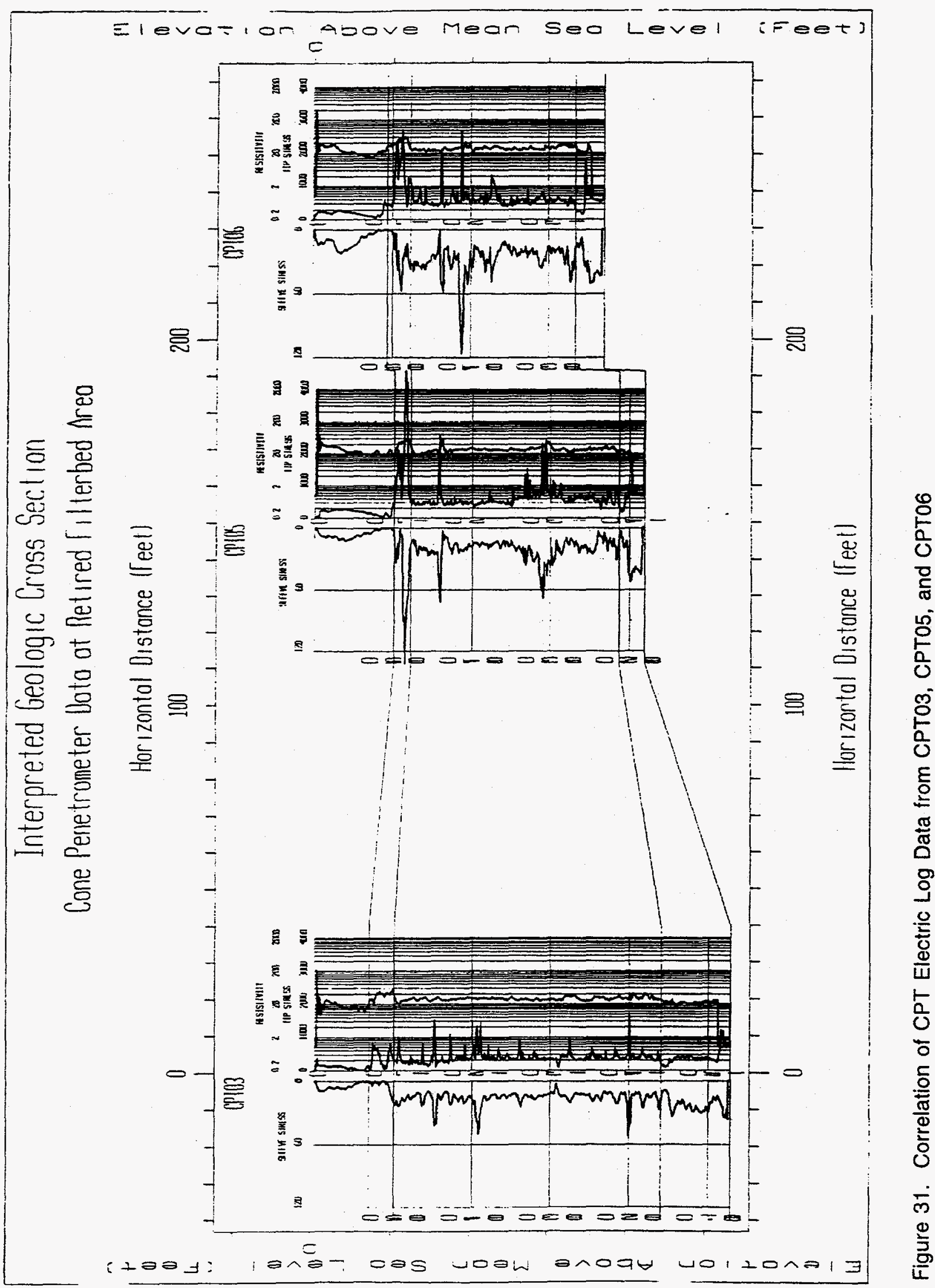




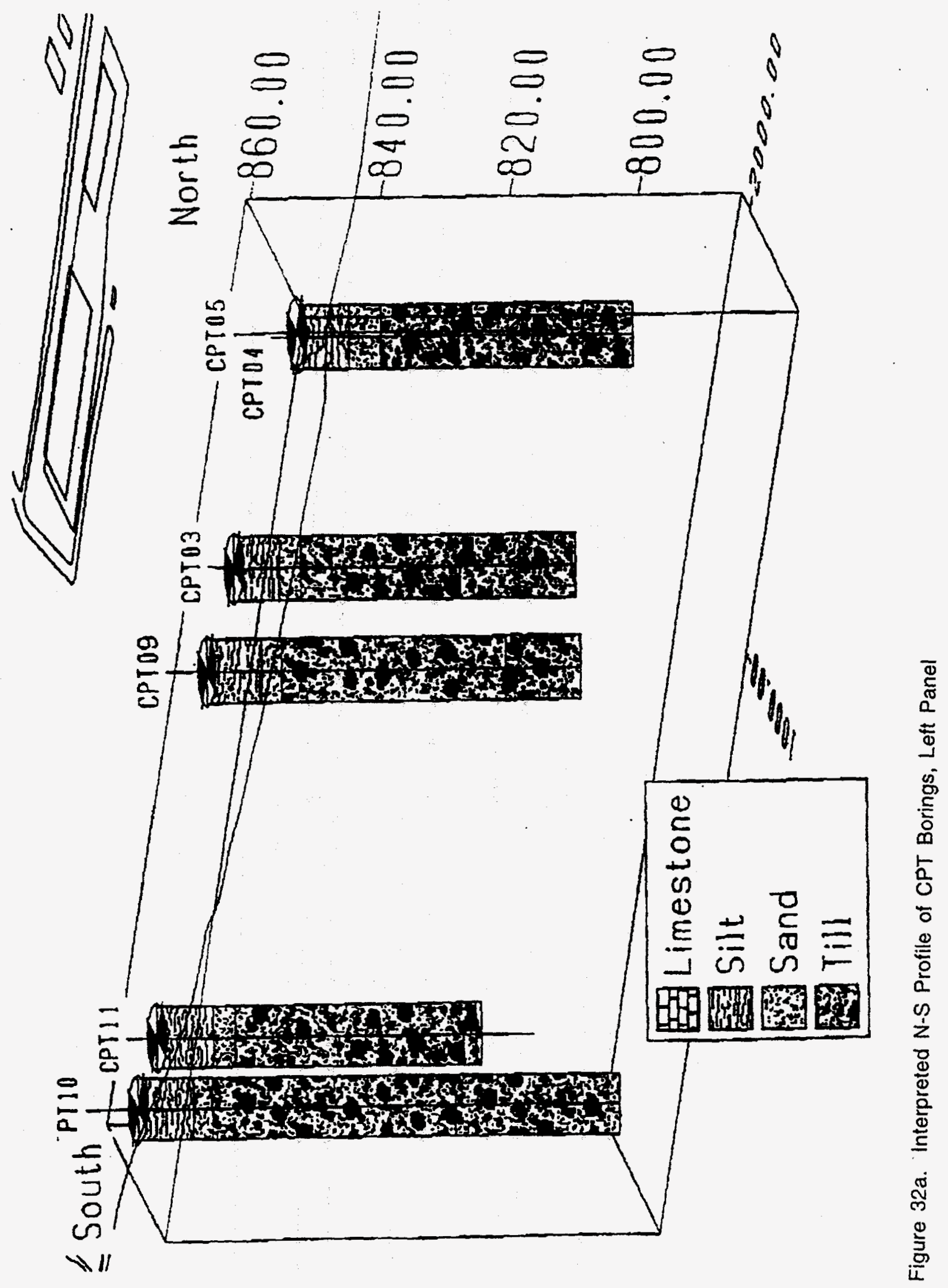




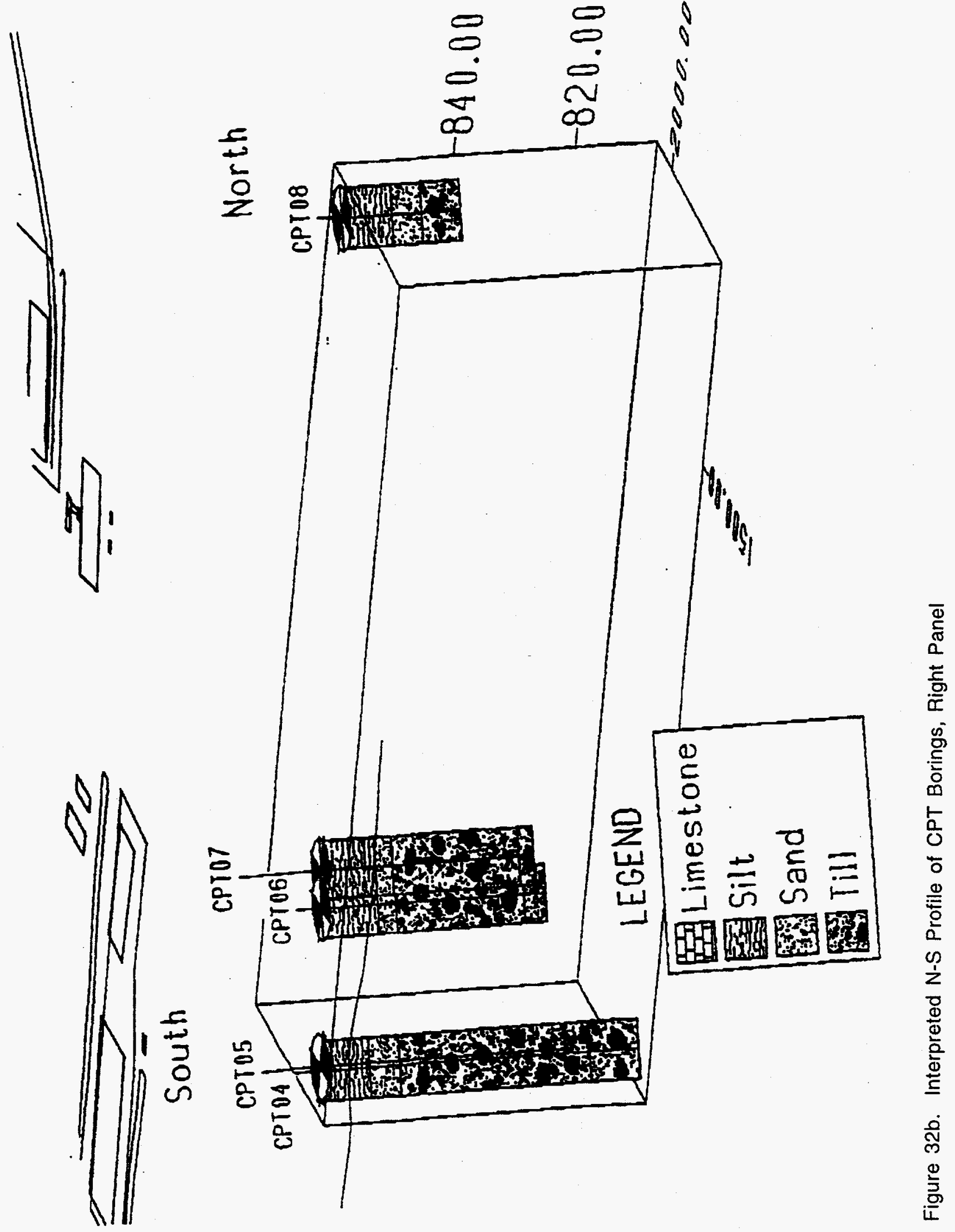




\section{Piezometer Measurements}

Groundwater levels were measured on five occasions at the six wellpoints: September 1995; October 9, 1995; November 8, 1995; November 22, 1995; and June 6, 1996. The measurements were obtained in an effort to better understand the fluctuation of groundwater in response to seasonal and climatic changes. The water levels were measured with an electric tape and reported to $\pm 0.01 \mathrm{ft}$. ANL personnel took the initial water level measurements in September 1995 , and BCLDP personnel obtained the measurements on the other events. In conjunction with the collection of groundwater levels, Battelle personnel also record barometric pressure and temperature at the time of measurements. As a result of the survey work that Woolpert performed on April 21, 1996, elevation control was obtained at the two Battelle surface water monitoring stations along Big Darby Creek. This was done so that Battelle, in the future, could measure water levels in the river in conjunction with the collection of groundwater measurements.

Details of well construction are listed in Table 5. Table 6 shows the groundwater measurements for the six piezometers, and Figures 33a and 33b illustrate the hydrographs for them. In Figure 33a, WP01, WP02, WP04, and WP06 behave similarly and have groundwater fluctuations between elevations 854 and 857 . Figure 33b shows that WP03 and WP05 have a narrower range of groundwater fluctuations, 853 to $854 \mathrm{ft}$, because of the proximity to the river stage. Associated with the groundwater measurements at the piezometers, BCLDP personnel also measured the groundwater levels in 13 existing monitoring wells in the retired filter bed area on November 22, 1995, and June 6, 1996. Groundwater elevation data for the 13 wells are presented in Table 7. The 13 wells were installed by Battelle in the 1990 investigation and were indicated to be approximately $10 \mathrm{ft}$ deep, with $2.5 \mathrm{ft}$ screens at the base. BCLDP recently sounded the depths of the wells. Although the existing 2-in.-diameter wells were installed blind, a number of wells are situated close to soil bores that were continuously sampled by Battelle. Among the limitations of these wells, the position of the screen may not coincide with the same lithologic unit between the holes or be optimal for monitoring the groundwater conditions. In terms of the new piezometers, five were located adjacent to a CPT hole, and one was installed without an adjacent CPT hole. Figure 34 shows the generalized geology associated with the piezometers at the retired filter bed area.

Table 5. Temporary Piezometer Locations

\begin{tabular}{|c|c|c|c|c|}
\hline \multirow[b]{2}{*}{ Piezometer I.D. } & \multicolumn{2}{|c|}{ Grid Coordinates } & \multirow{2}{*}{$\begin{array}{c}\text { Elevation (MSL, ft) } \\
\text { Top of } \\
\text { Inner Casing }\end{array}$} & \multirow{2}{*}{$\begin{array}{l}\text { Total Depth } \\
\text { Below Ground } \\
\text { Surface (ft) }\end{array}$} \\
\hline & North & East & & \\
\hline WP-01 & 765.10 & 749.04 & 863.81 & 12.06 \\
\hline WP-02 & 845.23 & 772.43 & 863.17 & 12.85 \\
\hline WP-03 & 819.71 & 839.06 & 859.99 & 9.80 \\
\hline WP-04 & 712.13 & 843.06 & 865.36 & 12.84 \\
\hline WP-05 & 505.08 & 661.44 & 863.11 & 12.72 \\
\hline WP-06 & 645.28 & 774.07 & 866.69 & 12.84 \\
\hline
\end{tabular}


Table 6. Groundwater Elevation Data for Six Well Points in the Battelle West Jefferson Retired Filter Bed Area

\begin{tabular}{ccccccc}
\hline & & \multicolumn{5}{c}{ Groundwater Elevation (ft) } \\
\cline { 3 - 7 } & $\begin{array}{c}\text { Reference } \\
\text { Elevation } \\
\text { Well }\end{array}$ & \multicolumn{7}{c}{ (ft, MSL) } & $9 / 24 / 95$ & $10 / 9 / 95$ & $11 / 8 / 95$ & $11 / 22 / 95$ & $6 / 6 / 96$ \\
\hline WP01 & 863.81 & 854.31 & 855.94 & 855.3 & 855.82 & 857.00 \\
WP02 & 863.17 & 854.34 & 856.04 & 855.32 & 855.93 & 857.22 \\
WP03 & 859.99 & 851.82 & 853.48 & 852.8 & 853.35 & 854.59 \\
WP04 & 865.36 & 854.27 & 855.85 & 855.22 & 855.72 & 856.96 \\
WP05 & $\mathbf{8 6 3 . 1 1}$ & $\mathbf{8 4 8 . 9 0}$ & $\mathbf{8 5 3 . 3 7}$ & $\mathbf{8 5 2 . 8 1}$ & $\mathbf{8 5 3 . 3 5}$ & $\mathbf{8 5 4 . 3 0}$ \\
WP06 & $\mathbf{8 6 6 . 6 9}$ & $\mathbf{8 5 4 . 2 6}$ & $\mathbf{8 5 5 . 7 4}$ & $\mathbf{8 5 5 . 1 2}$ & $\mathbf{8 5 5 . 5 9}$ & $\mathbf{8 5 6 . 8 4}$ \\
\hline
\end{tabular}

Table 7. Groundwater Elevation Data at the Battelle West Jefferson Retired Filter Bed Area

\begin{tabular}{|c|c|c|c|c|c|}
\hline \multirow[b]{2}{*}{ Well } & \multirow[b]{2}{*}{$\begin{array}{l}\text { Reference } \\
\text { Elevation } \\
\text { (ft, } \mathrm{MSL} \text { ) }\end{array}$} & \multicolumn{2}{|c|}{ November 22, 1995} & \multicolumn{2}{|c|}{ June 6,1996} \\
\hline & & $\begin{array}{l}\text { Groundwater } \\
\text { Depth (ft) }\end{array}$ & $\begin{array}{l}\text { Groundwater } \\
\text { Elevation (ft) }\end{array}$ & $\begin{array}{l}\text { Groundwater } \\
\text { Depth (ft) }\end{array}$ & $\begin{array}{l}\text { Groundwater } \\
\text { Elevation (ft) }\end{array}$ \\
\hline WP01 & 863.81 & 7.99 & 855.8 & 6.81 & 857 \\
\hline WP02 & 863.17 & 7.24 & 855.9 & 5.95 & 857.22 \\
\hline WP03 & 859.99 & 6.64 & 853.4 & 5.4 & 854.59 \\
\hline WP04 & 865.36 & 9.64 & 855.7 & 8.4 & 856.96 \\
\hline WP05 & 863.11 & 9.76 & 853.4 & 8.81 & 854.3 \\
\hline WP06 & 866.69 & 11.1 & 855.6 & 9.85 & 856.84 \\
\hline 122 & 864.97 & 8.82 & 856.2 & 7.36 & 857.61 \\
\hline 116 & 865.6 & 9.41 & 856.2 & 7.82 & 857.78 \\
\hline 118 & 863.64 & 7.65 & 856 & 5.78 & 857.86 \\
\hline 112 & 866.96 & 10.71 & 856.3 & 9.19 & 857.77 \\
\hline 101 & 863.76 & 7.83 & 855.9 & 6.5 & 857.26 \\
\hline 124 & 865.03 & 8.96 & 856.1 & 7.43 & 857.6 \\
\hline 125 & 865.4 & 9.38 & 856 & 7.81 & 857.59 \\
\hline 103 & 864.9 & 8.99 & 855.9 & 7.58 & 857.32 \\
\hline 129 & 866.8 & 10.77 & 856 & 9.31 & 857.49 \\
\hline 130 & 865.3 & 9.19 & 856.1 & 7.57 & 857.73 \\
\hline 111 & 868.24 & 11.96 & 856.3 & 10.31 & 857.93 \\
\hline 113 & 863.65 & 7.81 & 855.8 & 6.89 & 856.76 \\
\hline
\end{tabular}



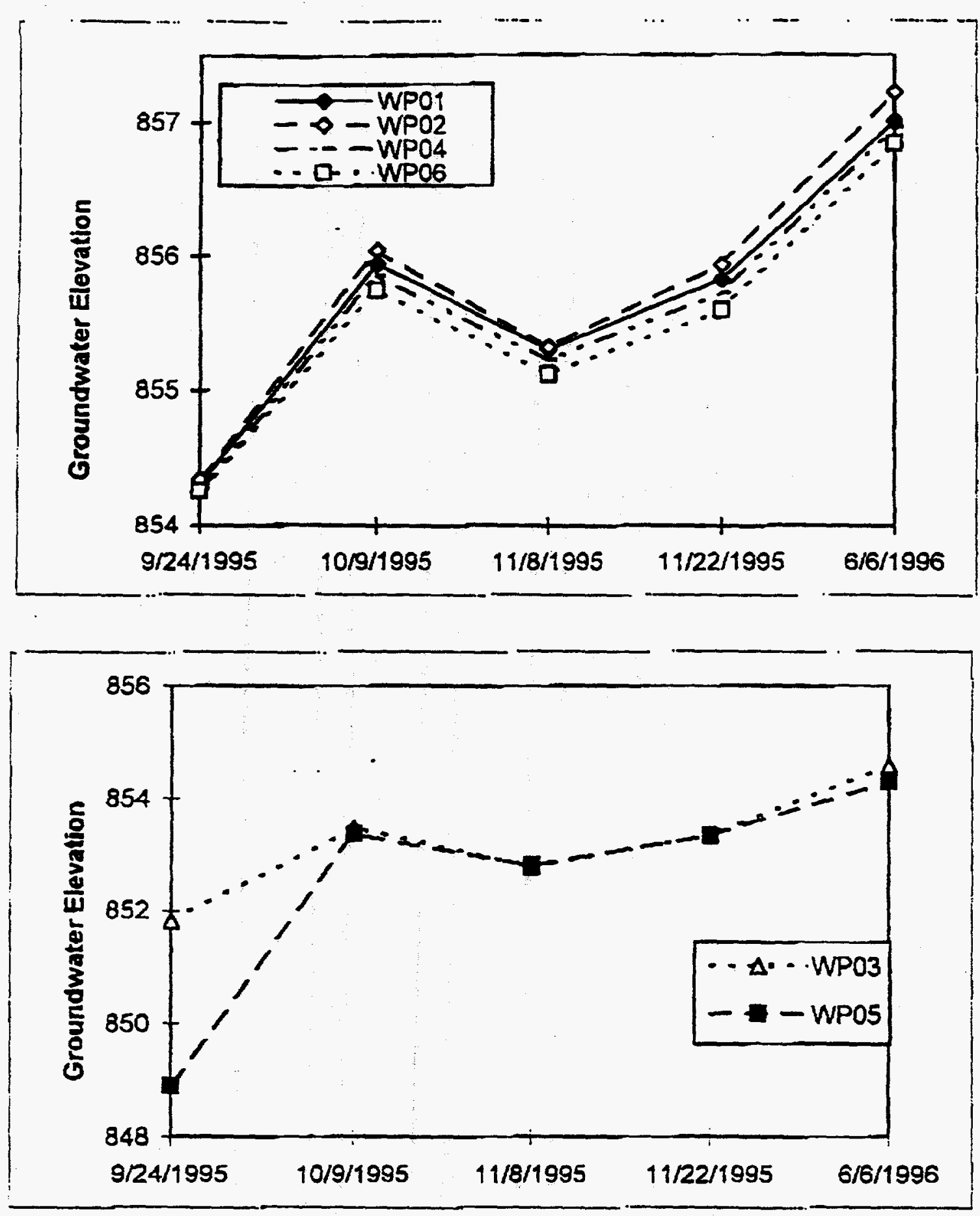

Figure 33. Hydrographs at Battelle West Jefferson Retired Filter Bed Area 


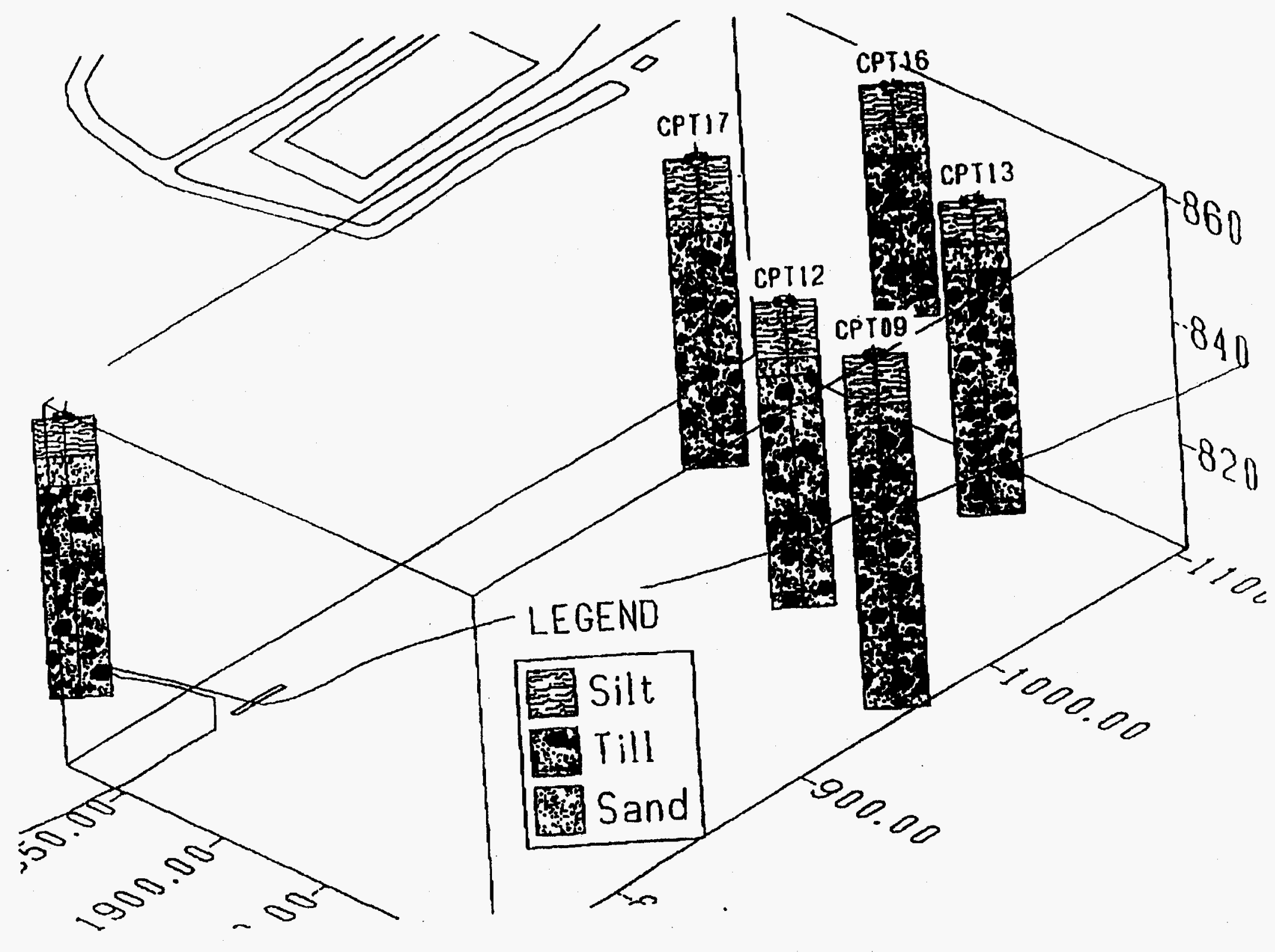

Figure 34. Interpreted Generalized Geology at Piezometer Locations 
Groundwater elevations from November 22, 1995, and June 6, 1996, were compiled into estimated potentiometric surface maps (Figures 35 and 36) for the retired filter bed area. The maps are based on groundwater-level measurements from the existing 2 -in., PVC-cased wells in the fenced retired filter bed area and from six piezometers. It is recommended that a complete synoptic round of groundwater levels from all the BWJ monitoring wells be collected on the same day sometime in the future. These figures both show that an east-to-west-trending divide exists in the groundwater flow system that extends from the eastern side of the abandoned retired filter beds toward Big Darby Creek. The low-relief topographic ridge on the top of the till that is visible from the CPT data suggests that a groundwater divide exists (Figure 32). Because of the groundwater divide feature, groundwater flow at the site has northeast and southeast components, and that relationship did not change with a rise in water levels during the observation period. On the basis of the November data, the hydraulic gradient between Well 113 and WP03 is calculated to be $0.023 \mathrm{ft}$ per foot for the northeast flow direction. This was determined by dividing the head difference $(4.45 \mathrm{ft}$ ) by the corresponding well separation distance (193.6 ft). Likewise, the hydraulic gradient in the southeast flow direction was calculated to be $0.017 \mathrm{ft}$ per foot between Well 110 and WP05, by dividing $2.49 \mathrm{ft}$ of head change by $145.45 \mathrm{ft}$ of map distance. Hydraulic conductivity values are not known at the retired filter bed area, but the hydraulic conductivity averaged $4.1 \mathrm{ft}$ per day from previous Battelle field measurements on similar coarse sediments present on the north bank of Battelle Lake (formerly Silver Creek). An estimate of horizontal groundwater velocity can be made by multiplying the hydraulic gradient by the hydraulic conductivity and dividing the product by effective porosity. A horizontal groundwater velocity of 0.38 feet per day was obtained by using 0.25 as the estimated effective porosity value $([0.023 \mathrm{ft} /$ foot $\times 4.1 \mathrm{ft} / \mathrm{day}] / 0.25)$. That amounts to a groundwater velocity of about $138 \mathrm{ft}$ per year.

Figure 37 is an east-to-west-trending hydrogeologic profile (A-A') that illustrates the groundwater conditions in the vicinity of the filter bed, based on available well data. The configuration of the potentiometric surface is shown for the two observation periods and there was approximately $1-1.5 \mathrm{ft}$ of fluctuation along the profile.

Groundwater sampling was performed in the piezometers on two occasions, October 1995 and June 1996.

BCLDP Environmental Support Group personnel performed groundwater sampling at the six piezometers (WP01 through WP06) on October 9, 1995, and on June 5, 1996. The purpose of the sampling was to screen for the possible presence of radionuclide contamination in the groundwater immediately east of the retired filter bed area. According to discussions with John Tholen of BCLDP, those sampling activities were conducted according to approved Battelle procedures, EM-SP-009 (Revision 1), and those procedures require purging of at least three well volumes prior to sample collection. The analytical work, involving gross alpha, gross beta, and gamma spectroscopy, was performed by the Battelle Laboratory facility at West Jefferson. A summary of the test results is provided in Appendix E. A number of duplicates were also tested for gross alpha and beta as a quality control measure. These analytical test results will also be reported in the next annual BCLDP Site Environmental Report. The data presented in Appendix E 


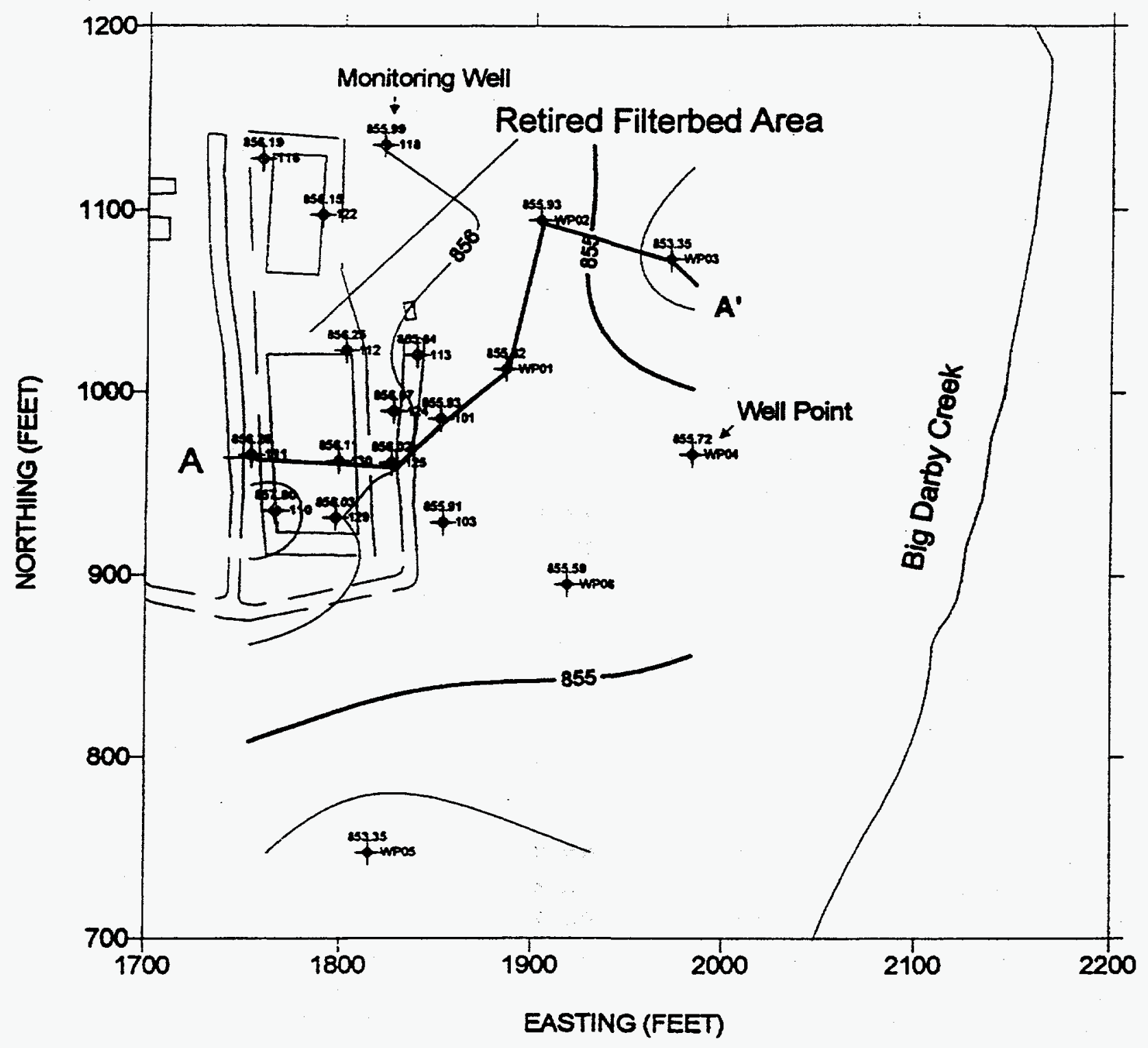

Figure 35. Potentiometric Surface Map for November 22, 1995, at Battelle West Jefferson 


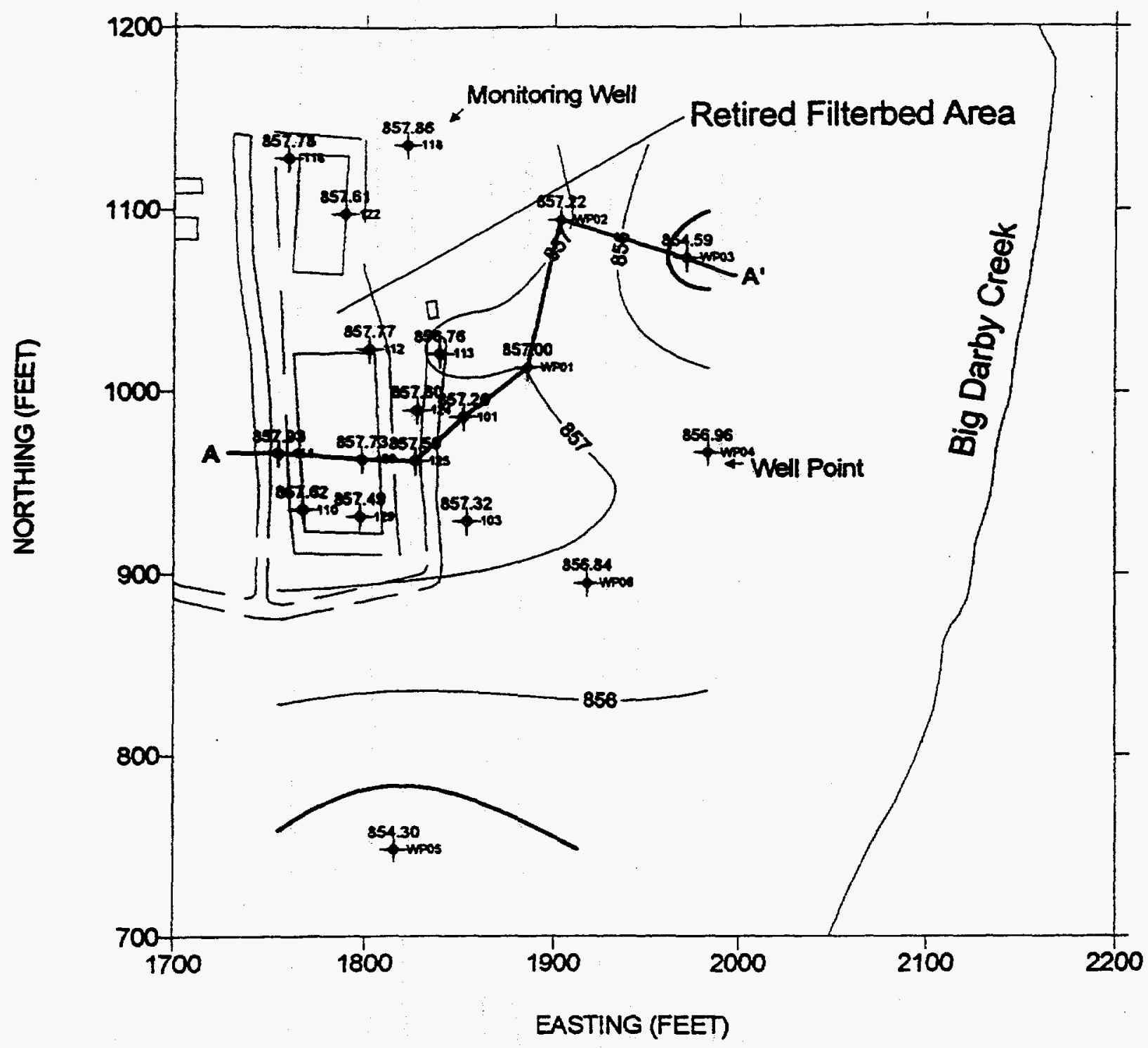

Figure 36. Potentiometric Surface Map for June 6, 1995, at Battelle West Jefferson 


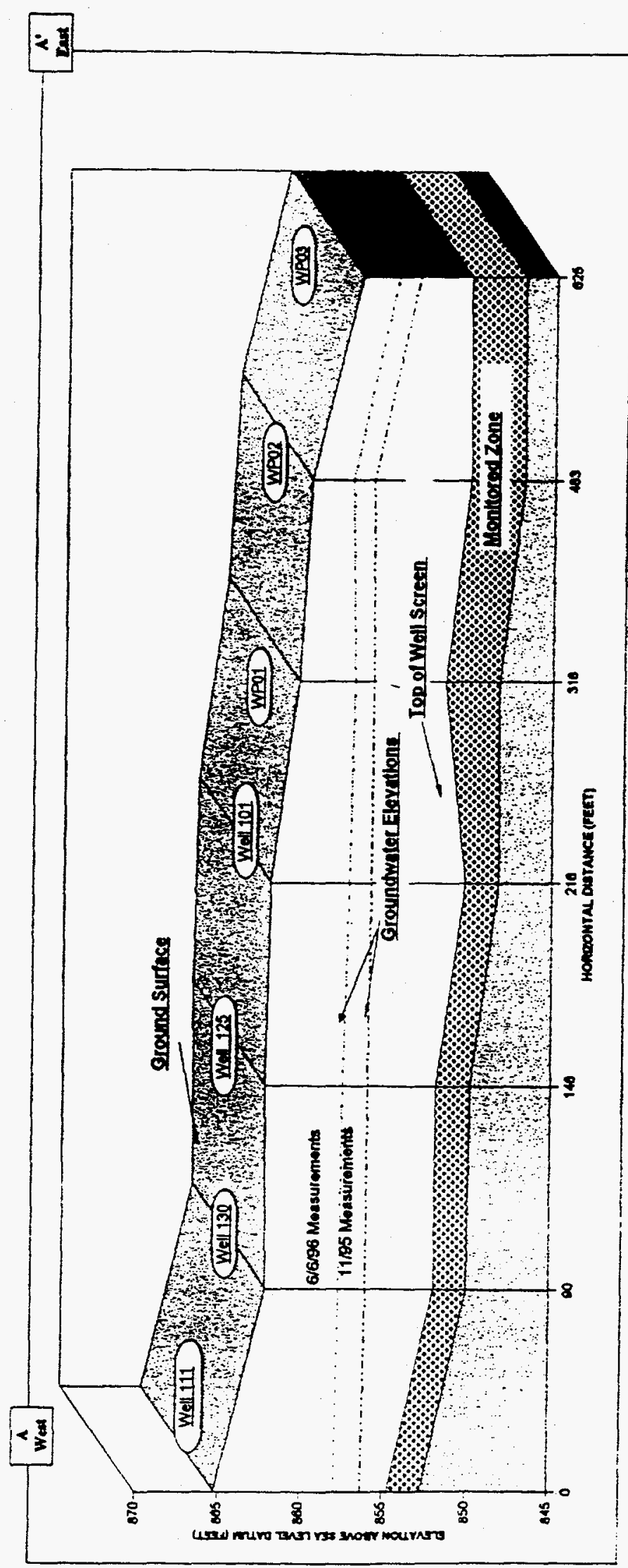

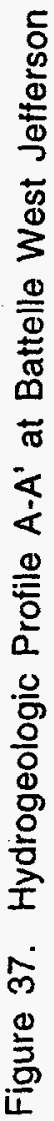


shows that gross beta levels in WP06 were 206 and $200 \mathrm{pCi} / \mathrm{L}$. This is elevated relative to the other piezometers sampled on October 5, 1995. In contrast, the gross beta results for WP06 from the June 5, 1996, sampling were not elevated with respect to the other piezometers. 


\section{Discussion}

By characterizing the bedrock surface beneath the area and the overburden sediments, nonintrusive geophysical surveys conducted at BWJ have placed constraints on the hydrogeologic framework. Piezometers were installed at six locations to test the groundwater for radiological contamination.

\subsection{Pleistocene/Holocene Stratigraphy and Structure}

Surveys employing EM, GPR, and CPT technologies were used to characterize any structures within the overburden that might be a pathway for contaminant migration and to locate the underground oil pipeline and any other anthropogenic structures in the geophysical survey area. A list of anomalies detected with the electromagnetic tools is presented in Table 8.

Table 8. Anomalies Detected by Electromagnetic Instruments

\begin{tabular}{|c|c|c|c|c|}
\hline \multicolumn{2}{|c|}{ Coordinates } & \multirow[b]{2}{*}{$E M-31$} & \multirow[b]{2}{*}{ EM-34 } & \multirow[b]{2}{*}{ Possible Source } \\
\hline$E$ & $N$ & & & \\
\hline $500-1050$ & $940-850$ & $\sqrt{ }$ & $\sqrt{ }$ & Pipeline \\
\hline $675-960$ & $500-760$ & $\sqrt{ }$ & & Filter bed \\
\hline $500-740$ & $640-957$ & $\checkmark$ & & Fence \\
\hline $560-880$ & $480-460$ & $\sqrt{ }$ & $\sqrt{ }$ & Discharge pipe and outfall \\
\hline $550-480$ & $720-620$ & $\sqrt{ }$ & & Buried metallic pipeline \\
\hline $500-570$ & $1070-1060$ & $\sqrt{ }$ & & Buried metallic pipeline \\
\hline 500 & $980-1080$ & $\sqrt{ }$ & & Fence \\
\hline 900 & 600 & $\sqrt{ }$ & & Barbed wire \\
\hline 960 & 940 & $\sqrt{ }$ & & Barbed wire \\
\hline $710-820$ & $920-1100$ & $\sqrt{ }$ & & Topographic low and wet area \\
\hline $620-710$ & $1000-1020$ & $\sqrt{ }$ & & Unknown \\
\hline $805-915$ & $830-745$ & $\sqrt{ }$ & & Unknown \\
\hline 970 & 770 & $\sqrt{ }$ & & Unknown \\
\hline 980 & $960-1120$ & & $\sqrt{ }$ & Unknown \\
\hline 600 & 1010 & $\sqrt{ }$ & & Concrete pit \\
\hline
\end{tabular}

EM-31, when compared with a topographic map of a segment of the survey area, shows a correlation between the surface topography and the electrical character of the sediments. This correlation arises from the degree of saturation of the soil, with the lower areas being more saturated and thus, more conductive. A more detailed topographic map of the survey area is needed to distinguish the difference due to saturated vs. unsaturated surface topography, as well as subsurface sediment variation. 
Conductivities measured with the EM-34 correlate closely with those of the EM-31 (Figure 38). The subtle conductivity minimum detected with the EM-34 along $900 \mathrm{E}$ is absent from the EM-31 data, suggesting a deeper source for this anomaly. Differences detected within about $60-70 \mathrm{ft}$ of the pipeline can be attributed to cultural interference.

Three geologic units within the unconsolidated overburden material have been interpreted from comparison of CPT logs with existing knowledge of the geology in the area and published tables of CPT responses. However, without other geologic control (such as a deep borehole), the exact composition of each unit must be considered speculative. An alluvial/fluvial layer, probably consisting of silty clay to silt, is interpreted to lie near the surface. At a depth of 6-10 ft, a distinctive unit 2-5 ft thick is observed in all CPT logs (Figures 30 and 31); it is probably an outwash layer consisting of coarser-grained sediments, probably silty sand to sand. A cohesive layer, consisting primarily of tills, is observed beneath the sandy layer.

GPR profiles alone are often difficult to interpret. However, several CPT holes lie adjacent to profiles 2 (Figure 22) and 16 (Figure 23), providing a unique "ground-truthing" for the GPR observations. Note that both GPR profiles suggest the presence of a reflective geologic unit within the unconsolidated overburden at depth. However, the unit's upper and lower boundaries are not always well-defined and may be gradational in places. The bottom of this contact is more difficult to pick out on both GPR profiles and CPT electric logs. Both techniques may be mapping the same geologic unit; the lower boundary of this unit is distinct near the southern end of GPR profile 16 (Figure 22) and at $10 \mathrm{ft}$ below the ground surface on the electric log from CPT-03 to CPT-04 and CPT-05 (Figure 30). If the GPR anomalies correlate with the outwash layer defined from CPT observations, then a relatively high two-way travel time of $12 \mathrm{~ns} / \mathrm{ft}$ is needed, suggesting a material of very high porosity.

Although distinct channels were not detected by means of geophysical observations, the outwash deposit, consisting of a thin silty sand to sand layer observed at depths of less than $12 \mathrm{ft}$, represents a significant pathway for contaminant migration at Battelle West Jefferson.

The location of the buried oil pipeline is defined by anomalies in the EM-31, EM-34, and magnetic gradiometer observations. Failure to detect the oil pipeline as a GPR anomaly suggests that the pipe diameter is small and/or that the pipe is deeply buried. Two other lineaments (pipes) were detected as EM-31 anomalies in the western half of the survey area, between (720N, 550E) and $(480 \mathrm{~N}, 620 \mathrm{E})$ and between $(1070 \mathrm{~N}, 500 \mathrm{E})$ and $(1060 \mathrm{~N}, 570 \mathrm{E})$.

Other anthropogenic structures are detected within the fenced filter bed area. GPR transects depict at least two EW-trending buried pipes adjacent to the retired filter beds. Since interference from surface metals within the fenced area prevents the electromagnetic methods (EM-31 and EM-34) from detecting these pipes, the lateral extent of these pipes is unknown; they were not detected by any geophysical technique outside of the fenced area. Inside this area, GPR reflections from the former filter beds are observed. Other GPR reflections at greater depths may originate from fill material or geologic sources. 


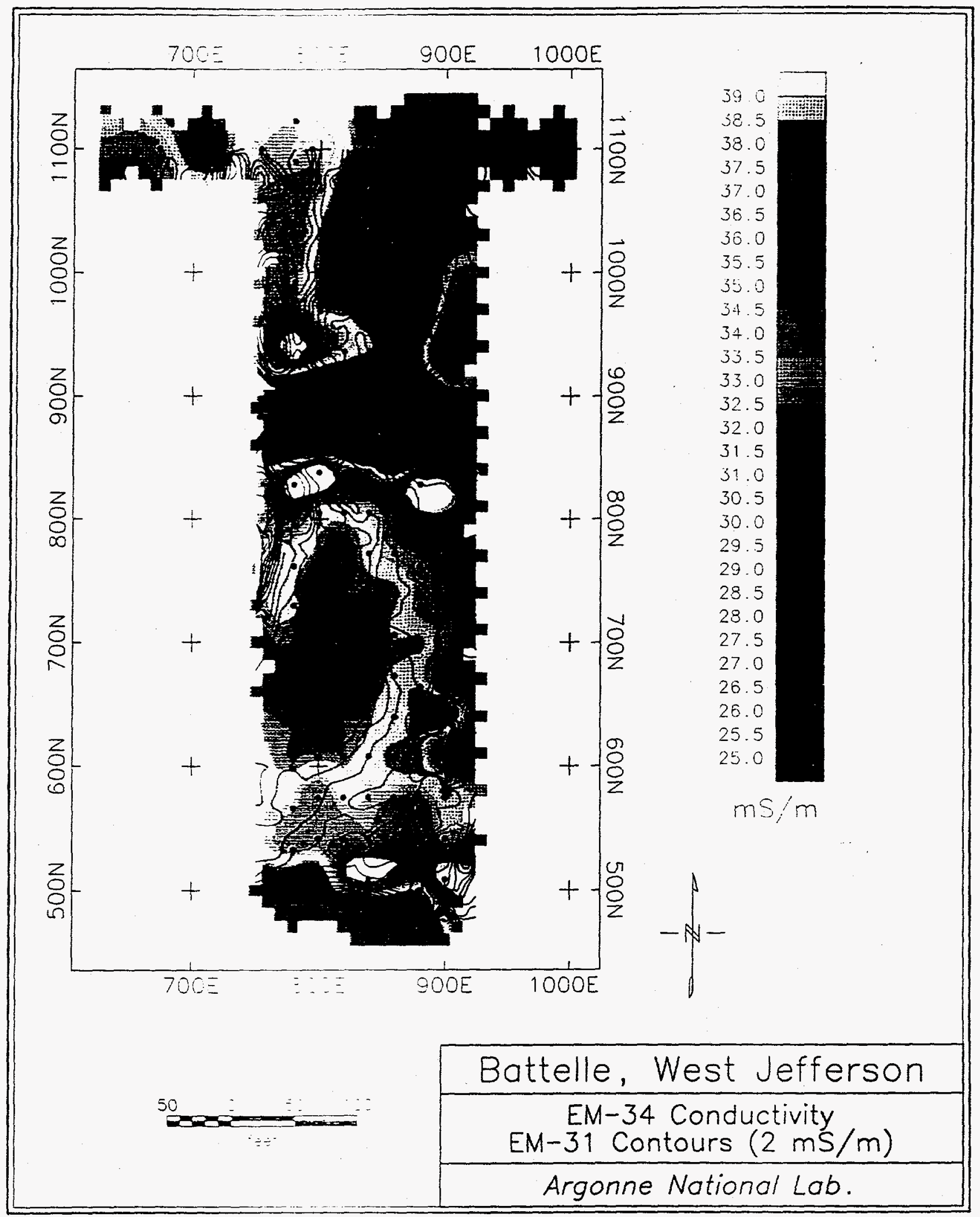

Figure 38. Map of Terrain Conductivities Measured by the EM-34, Overlayed with Contours of E::-31 Anomalies 


\subsection{Bedrock Topography}

Measured resistivities for the overburden and bedrock are consistent with previously published values. Overburden resistivities ranged from 16 to $70 \mathrm{ohm}-\mathrm{m}$ with layer thicknesses from 30 to $180 \mathrm{ft}$. Resistivities measured from CPT logs are comparable, ranging from 18 to $80 \mathrm{ohm}-\mathrm{m}$ in the upper $78 \mathrm{ft}$ of overburden. The resistivity of the bedrock showed the greatest variation, ranging from approximately 95 to greater than $500 \mathrm{ohm}-\mathrm{m}$. Norris and Spicer (1958) also noted variations in the bedrock resistivity values and determined that the bedrock resistivity within preglacial valleys will be lower that than observed in bedrock uplands.

Is it of concern that the bedrock surface could be misidentified because the lower limit of the bedrock resistivity $(100 \mathrm{ohm}-\mathrm{m})$ is within the range of resistivities observed for till and gravel deposits (22 to $600 \mathrm{ohm}-\mathrm{m}$; see Norris and Spicer 1958). Comparison between the bedrock elevations determined from the refraction and resistivity data is required to verify that observed changes in resistivity (from 16 to $70 \mathrm{ohm}-\mathrm{m}$ to greater than $100 \mathrm{ohm}-\mathrm{m}$ ) correspond to the overburden bedrock interface. In Figures 25 and 27 , the depths obtained from the resistivity inversion are overlain on the velocity-depth cross sections for refraction Lines 1 and 6 . Each resistivity depth point is indicated on the cross section by a solid circle and station number label. For Line 1, four of the resistivity depths plot within $15 \mathrm{ft}$ of the seismic refraction bedrock surface. Agreement between the two depth estimates varies between about $15 \mathrm{ft}$ at the northern end of Line 6 to about $25-30 \mathrm{ft}$ at the southern end.

Depths to bedrock obtained by CPT observations provide ground truth for seismic refraction modeling along Line 4 . Bedrock depths of six of the CPT holes $(3-7,9)$ plot on the bedrock surface determined from seismic refraction modeling (Figure 26). At CPT holes \#3 and $\# 4$, the differences in bedrock elevations are slightly larger because of high gradients in the bedrock surface at this location.

A bedrock topography map constructed from elevations obtained from seismic refraction modeling and CPT holes is shown in Figure 39. Bedrock elevations obtained from seismic refraction Line 1 were excluded from this figure because of the possible bias introduced from the anthropogenic structures associated with the dam. The seismic profiles are plotted as heavy lines. Within the survey area, the bedrock surface slopes to the southwest, changing in elevation from approximately $840 \mathrm{ft}$ in the NE corner to $730 \mathrm{ft}$ near the southern boundary of the geophysical survey area. The configuration of the bedrock surface beneath the dam was not resolvable with the data collected. 


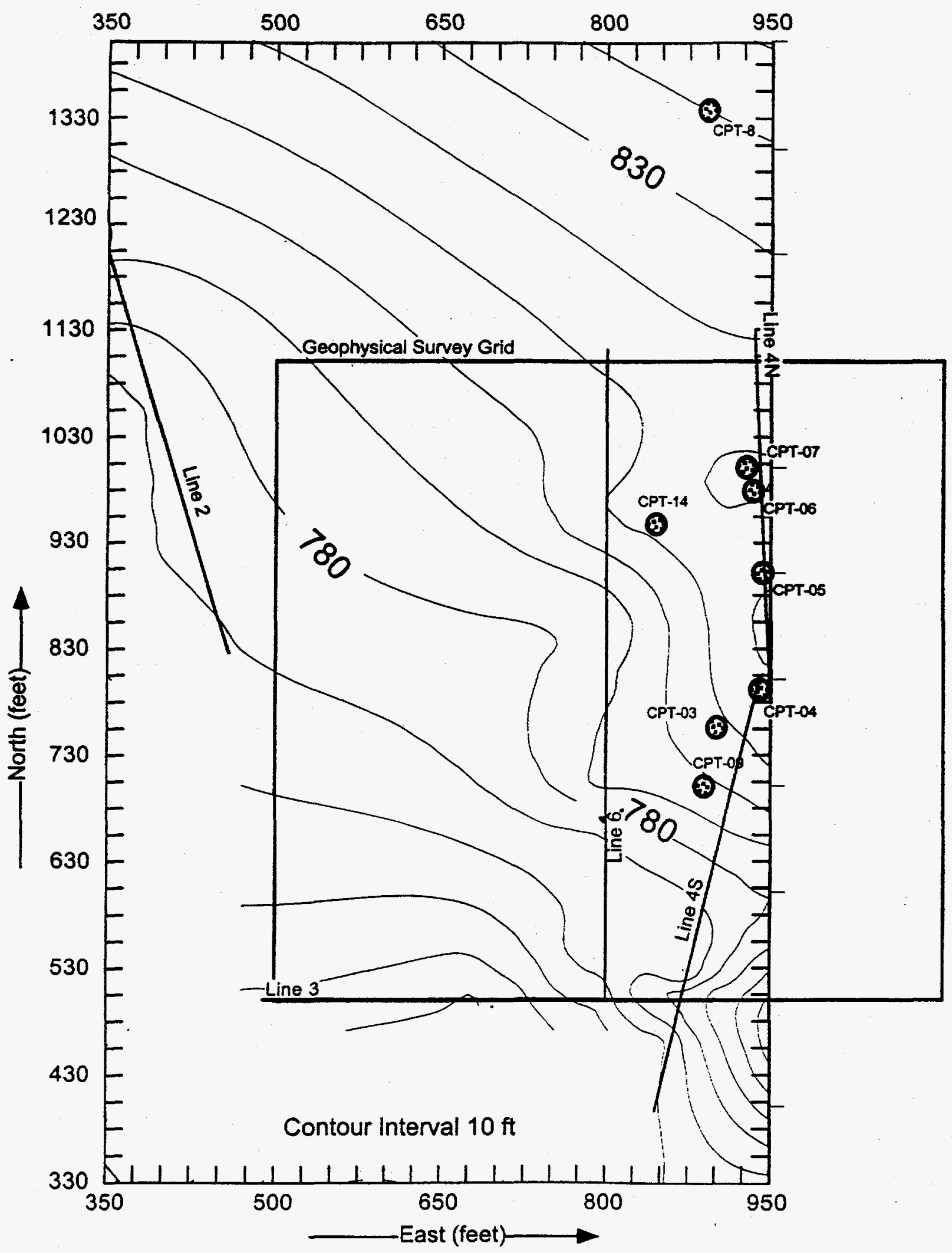

Figure 39. Map of Bedrock Elevations Determined from Seismic Modeling 


\section{Conclusions and Recommendations}

The geophysical investigation yielded an improved understanding of the geology of the filter bed area and of the floodplain of the Big Darby Creek. The study established that the preferred groundwater pathway is associated with a laterally extensive, silty-sand to sand deposit that is less than $12 \mathrm{ft}$ deep in the floodplain area. Resistivity and seismic refraction data provide a framework to improve understanding of the geology of the till deposits and the bedrock surface in the area of the floodplain. The intrusive CPT technology is particularly useful for comparing continuous logging data with surface geophysical data and in establishing correlations among the unconsolidated geologic materials.

The following recommendations are made with respect to future geophysical surveys:

1. Conduct a geophysical survey involving resistivity and seismic refraction profiles and soundings to determine the depth of bedrock and the suspected buried valley underlying the JN/Battelle Lake area, as well as on the south shore of Battelle Lake. This information will help in understanding the geological framework of the Battelle site and the distribution of granular and more transmissive layers as potential pathways.

2. Conduct natural gamma logging on the existing groundwater monitoring wells. 


\section{References}

Beard, T.C., and N. Gupta, 1990, Geology and Hydrogeology of West Jefferson North Site, draft Battelle Report, Sept.

Bigham, J.M., N.E. Smeck, L.D. Norton, G.F. Hall, and M.L. Thompson, 1991, "Lithology and General Stratigraphy of Quaternary Sediments in a Section of the Teays River Valley of Southern Ohio," W.N. Melhom and J.P. Kempton, eds., Geology and Hydrogeology of the Teays-Mahomet Bedrock Valley System, Boulder, Colo., Geological Society of America Special Paper 258.

Burgess and Niple, Ltd., 1966, Letter reports to B.K. Bare, Battelle Memorial Institute, January 28 and February 10.

Chiang, C.Y., K.R. Loos, and R.A. Klopp, 1992, Field Determination of Geological/Chemical Properties of an Aquifer by Cone Penetrometry and Headspace Analysis, Ground Water, 30(3):428-436, May-June.

Couchot, M.L., 1975, "Sand and Gravel Resources of Madison County, Ohio," Ohio Department of Natural Resources, Division of Geological Survey, Geological Note No. 2.

Galinovsky, L., and K. Levin, 1990, Radan III, Geophysical Survey Systems, Inc., North Salem, N.H.

Geophysical Survey Systems, Inc., 1987, Operations Manual for Subsurface Interface Radar (SIR System-3), North Salem, N.H.

Goldthwait, R.P., 1952, "The Glacial Deposits," The Water Resources of Clark County, Ohio, Ohio Department of Natural Resources, Division of Water, Bulletin 32.

Goldthwait, R.P., and R.R. Pavey, 1993, "Quaternary Geology of Ohio, Marion, Ohio Quadrangle," Ohio Department of Natural Resources, Division of Geological Survey, Open-File Map 295.

Goldthwait, R.P., and R.G. Van Horn, 1993, "Quaternary Geology of Ohio, Columbus, Ohio Quadrangle," Ohio Department of Natural Resources, Division of Geological Survey, Open-File Map 298. 
Goldthwait, R.P., 1969, "Till Stratigraphy from Columbus Southwest to Highland County, Ohio," Third Annual Meeting, Geological Society of America, North-Central Section, Field Trip No. 2:2-1 to $2-17$.

Hansen, M.C., 1987, Ohio Geology Newsletter, The Teays River, Ohio Department of Natural Resources, Division of Geological Survey, pp. 1-6.

Hansen, M.C., 1995, GeoFacts No. 10, The Teays River, Ohio Department of Natural Resources, Division of Geological Survey, Nov.

Jewel, G.K., and Associates, 1971, Soils Investigation for the Proposed Hot Cell, West Jefferson, Ohio, report to Battelle Memorial Institute, March.

Klaer, F.H., and Associates, 1963, Letter report to C.T. Greenridge, Battelle Memorial Institute, April.

McNeill, J.D., 1980, Electromagnetic Terrain Conductivity Measurement at Low Induction Numbers, Technical Note TN-6, Geonics Ltd., Mississauga, Canada.

Melhorn, W.N., and J.P. Kempton, 1991, Geology and Hydrogeology of the Teays-Mahomet Bedrock Valley System, Geological Society of America, Special Paper 258.

Norris, S.E., 1951, The Bedrock Surface and the Distribution of the Consolidated Rocks in Montgomery, Greene, Clark, and Madison Counties, Ohio, Ohio Journal of Science, LI(1):13-15, Jan.

Norris, S.E., and H.C. Spicer, 1958, Geological and Geophysical Study of the Preglacial Teays Valley in West-Central Ohio, Geological Survey Water-Supply Paper 1460-E, pp. 199-232.

Norris, S.E., 1959, Minford Silt and Ground Water Quality in Western Ohio, Journal of the American Water Works Association, 51(9), Sept.

Norris, S.E., 1959, "The Water Resources of Madison County, Ohio," Ohio Department of Natural Resources, Division of Geological Survey, Bulletin 33.

Orton, E., Sr., 1878, Report of the Geology of Madison County, Third Ohio Geological Survey Report, Geology and Paleontology. Part I. Geology, Columbus, Ohio. Ch. 73, pp. 421-428.

Patridge, R.T., and Associates, 1990, Topographic Survey Elevation Data for West Jefferson Site, data provided to Battelle Memorial Institute, Sept. 
Robertson, P.K., and R.G. Campanella, 1986, Guidelines for Use and Interpretation of the Electronic Cone Penetrometer Test, Third Edition, The University of British Columbia, Nov.

Scott, J.H., 1973, Seismic Refraction Modeling by Computer, Geophysics, 38(2):271-284.

Scott, J.H., 1977, SIPT - A Seismic Refraction Inverse Modeling Program for Time-Share Terminal Computer Systems, U.S. Geological Survey Open-File Reports 77-366.

Smolley, M., and Kappmeyer, 1991, Cone Penetrometer Tests and Hydropunch Sampling: A Screening Technique for Plume Definition, Ground Water Monitoring \& Review, Spring, pp. 101-106.

Steiger, J.R., and N. Holowaychuck, 1971, Particle Size and Carbonate Analysis of Glacial Till and Lacustrine Deposits in Western Ohio, R.P. Goldthwait, ed., Till, a Symposium, Ohio State University Press, Columbus, Ohio, pp. 275-289.

Stuckey, R.L., and K.J. Reese, 1981, The Prairie Peninsula Biological Survey, Biological Notes No. 15.

Stuckey, R.L., and K.J. Reese, 1981, The Prairie Peninsula, in the "Shadow" of Transeau: Proceedings of the Sixth North American Prairie Conference, Ohio State University, Columbus, Ohio, Aug. 12-17, Ohio References.

Sugar, D., and D. Shrake, 1993, "Bedrock Topography Map of the Galloway, Ohio, Quadrangle Map," Ohio Department of Natural Resources, Division of Geological Survey, Open-File Report BT-B4H2.

Szabo, J.P., and S.M. Totten, 1995, Multiple Pre-Wisconsinan Glaciations along the Northwestern Edge of the Allegheny Plateau in Ohio and Pennsylvania, Canadian Journal of Science, 32:2081-2089.

Teller, J.T., and R.P. Goldthwait, 1991, "The Old Kentucky River, A Major Tributary to the Teays River," W.N. Melhorn and J.P. Kempton, eds., Geology and Hydrogeology of the TeaysMahomet Bedrock Valley System: Boulder, Colo., Geological Society of America, Special Paper 258.

U.S. Department of Agriculture, 1981, "Soil Survey of Madison County, Ohio," Soil Conservation Service in cooperation with the Ohio Department of Natural Resources, U.S. Government Printing Office, June. 
Vormelker, J.D., and D. Shrake, 1990, "Bedrock Topography Map of the West Jefferson, Ohio, Quadrangle Map," Ohio Department of Natural Resources, Division of Geological Survey, OpenFile Report BT-B4H3.

Vormelker, J.D., 1991, "Bedrock Topography Map of the Plain City, Ohio, Quadrangle Map," Ohio Department of Natural Resources, Division of Geological Survey, Open-File Report BT-C4A3.

Wolfe, P.J., and B.H. Richard, 1992, Integrated Geophysical Studies of Buried Valleys, 1992 Symposium on the Application of Geophysics to Engineering and Environmental Problems, Environment and Engineering Geophysical Society, Oak Brook, Ill., pp. 531-550.

Zemo, D.A., Y.G. Pierce, and J. Gallinatti, 1994, Cone Penetrometer Testing and DiscreteDepth Ground Water Sampling Techniques: A Cost-Effective Method of Site Characterization in a Multiple Aquifer Setting, Ground Water Monitoring \& Remediation, Fall, pp. 176-182. 
APPENDIX A:

RESISTIVITY DEPTH SOUNDING CURVES 


\section{WJE1A}

\begin{tabular}{ccc}
\hline$L_{\#}$ & $\begin{array}{c}\text { Resistivity } \\
(\Omega-m)\end{array}$ & $\begin{array}{c}\text { Thickness } \\
\text { (meters) }\end{array}$ \\
\hline 1 & 25.6 & 1.1 \\
2 & 49.4 & 2.5 \\
3 & 8.4 & 2.3 \\
4 & 132.7 & 58.4 \\
5 & $500.0^{*}$ & \\
\hline Indicates Fixed Parameter
\end{tabular}

- Indicates Fixed Parameter

WJE2

\begin{tabular}{ccc}
\hline$L \#$ & $\begin{array}{c}\text { Resistivity } \\
(\Omega-m)\end{array}$ & $\begin{array}{c}\text { Thickness } \\
\text { (meters) }\end{array}$ \\
\hline 1 & 23.1 & 5.7 \\
2 & 54.8 & 24.4 \\
3 & 64.1 & 2.1 \\
4 & $500.0^{*}$ & \\
\hline
\end{tabular}

- Indicates Fixed Parameter

W JE3

\begin{tabular}{ccc}
\hline $\mathrm{L} \#$ & $\begin{array}{c}\text { Resistivity } \\
(\Omega-\mathrm{m})\end{array}$ & $\begin{array}{c}\text { Thickness } \\
\text { (meters) }\end{array}$ \\
\hline 1 & 25.7 & 0.3 \\
2 & 21.4 & 1.7 \\
3 & 27.1 & 8.1 \\
4 & 59.6 & 23.2 \\
5 & $500.0^{*}$ & \\
\hline Indicates Fixed Parameter &
\end{tabular}


W JE 4

\begin{tabular}{ccc}
$L \neq$ & $\begin{array}{c}\text { Resistivity } \\
(\Omega-\mathrm{m})\end{array}$ & $\begin{array}{c}\text { Thickness } \\
\text { (meters) }\end{array}$ \\
\hline 1 & 31.3 & 0.3 \\
2 & 20.1 & 1.8 \\
3 & 29.0 & 12.4 \\
4 & 46.9 & 15.3 \\
5 & $500.0^{\circ}$ & \\
\hline
\end{tabular}

- Indicates Fixed Parameter

W JE5

\begin{tabular}{ccc}
\hline$L \#$ & $\begin{array}{c}\text { Resistivity } \\
(\Omega-m)\end{array}$ & $\begin{array}{c}\text { Thickness } \\
\text { (meters) }\end{array}$ \\
\hline 1 & 37.7 & 0.6 \\
2 & 12.9 & 0.4 \\
3 & 28.2 & 6.6 \\
4 & 39.0 & 29.3 \\
5 & $500.0^{*}$ & \\
\hline Indicates Fixed Parameter &
\end{tabular}

- Indicates Fixed Parameter

WJD 1

\begin{tabular}{ccc}
\hline$L \#$ & $\begin{array}{c}\text { Resistivity } \\
(\Omega-m)\end{array}$ & $\begin{array}{c}\text { Thickness } \\
\text { (meters) }\end{array}$ \\
\hline 1 & 16.6 & 2.7 \\
2 & 26.8 & 7.7 \\
3 & 94.2 & 49.2 \\
4 & $500.0^{-}$ & \\
\hline
\end{tabular}

- Indicates Fixed Parameter 


\section{W JD2}

\begin{tabular}{ccc}
\hline L\# & $\begin{array}{c}\text { Resistivity } \\
(\Omega \cdot \mathrm{m})\end{array}$ & $\begin{array}{c}\text { Thickness } \\
\text { (meters) }\end{array}$ \\
\hline 1 & 4.6 & 1.7 \\
2 & 0.1 & 0.0 \\
3 & 21.5 & \\
\hline \multicolumn{2}{l}{ All parameters are free } &
\end{tabular}

WJD3

\begin{tabular}{ccc}
\hline L\# & $\begin{array}{c}\text { Resistivity } \\
(\Omega-m)\end{array}$ & $\begin{array}{c}\text { Thickness } \\
\text { (meters) }\end{array}$ \\
\hline 1 & 16.4 & 0.5 \\
2 & 141.9 & 0.2 \\
3 & 26.7 & 19.5 \\
4 & 180.0 & 108.6 \\
5 & $500.0^{*}$ & \\
\hline
\end{tabular}

- Indicates Fixed Parameter

WJD 4

\begin{tabular}{ccc}
\hline$L \#$ & $\begin{array}{c}\text { Resistivity } \\
(\Omega-m)\end{array}$ & $\begin{array}{c}\text { Thickness } \\
\text { (meters) }\end{array}$ \\
\hline 1 & 29.7 & 1.3 \\
2 & 38.8 & 8.3 \\
3 & 6.9 & 5.0 \\
4 & $500.0^{*}$ & \\
\hline
\end{tabular}

- Indicates Fixed Parameter 
WJDSA

\begin{tabular}{ccc}
\hline$L \#$ & $\begin{array}{c}\text { Resistivity } \\
(\Omega-m)\end{array}$ & $\begin{array}{c}\text { Thickness } \\
\text { (meters) }\end{array}$ \\
\hline 1 & 235.4 & 0.2 \\
2 & 35.5 & 23.8 \\
3 & 11.3 & 8.5 \\
4 & $500.0^{*}$ & \\
\hline
\end{tabular}

- Indicates Fixed Parameter

WJDG

\begin{tabular}{ccc}
\hline L\# & $\begin{array}{c}\text { Resistivity } \\
(\Omega-\mathrm{m})\end{array}$ & $\begin{array}{c}\text { Thickness } \\
\text { (meters) }\end{array}$ \\
\hline 1 & 46984.7 & 0.1 \\
2 & 30.1 & 32.6 \\
3 & 183.6 & 179.7 \\
4 & $500.0^{*}$ & \\
\hline
\end{tabular}

- Indicates Fixed Parameter

WJD7

\begin{tabular}{ccc}
\hline$L \#$ & $\begin{array}{c}\text { Resistivity } \\
(\Omega-m)\end{array}$ & $\begin{array}{c}\text { Thickness } \\
\text { (meters) }\end{array}$ \\
\hline 1 & 83.5 & 0.5 \\
2 & 6.2 & 0.2 \\
3 & 24.9 & 12.4 \\
4 & 41.2 & 31.4 \\
5 & $500.0^{*}$ & \\
\hline Indicates Fixed Parameter
\end{tabular}


WJC10

\begin{tabular}{ccc}
\hline$L \neq$ & $\begin{array}{c}\text { Resistivity } \\
(\Omega-m)\end{array}$ & $\begin{array}{c}\text { Thickness } \\
\text { (meters) }\end{array}$ \\
\hline 1 & 11.0 & 0.8 \\
2 & 24.1 & 4.9 \\
3 & 35.0 & 20.4 \\
4 & $500.0^{*}$ & \\
\hline Indicates & Fixed Parameter &
\end{tabular}

WJCl100

\begin{tabular}{ccc}
\hline$L \#$ & $\begin{array}{c}\text { Resistivity } \\
(\Omega-m)\end{array}$ & $\begin{array}{c}\text { Thickness } \\
\text { (meters) }\end{array}$ \\
\hline 1 & 13.7 & 1.3 \\
2 & 24.1 & 15.0 \\
3 & 194.3 & 94.9 \\
4 & $500.0^{*}$ & \\
\hline
\end{tabular}

- Indicates Fixed Parameter

WJC1200

\begin{tabular}{ccc}
\hline$L \#$ & $\begin{array}{c}\text { Resistivity } \\
(\Omega-m)\end{array}$ & $\begin{array}{c}\text { Thickness } \\
\text { (meters) }\end{array}$ \\
\hline 1 & 2197.3 & 0.1 \\
2 & 22.0 & 2.6 \\
3 & 27.1 & 18.4 \\
4 & 240.1 & 235.7 \\
5 & $500.0^{*}$ & \\
\hline
\end{tabular}

- Indicates Fixed Parameter 
W JC1300

\begin{tabular}{ccc}
\hline$L \neq$ & $\begin{array}{c}\text { Resistivity } \\
(\Omega-m)\end{array}$ & $\begin{array}{c}\text { Thickness } \\
\text { (meters) }\end{array}$ \\
\hline 1 & 3.7 & 0.0 \\
2 & 16.6 & 2.8 \\
3 & 27.8 & 23.1 \\
4 & 2128.9 & 19.0 \\
5 & $500.0^{*}$ & \\
\hline
\end{tabular}

W JC1400

\begin{tabular}{ccc}
\hline$L \#$ & $\begin{array}{c}\text { Resistivity } \\
(\Omega-m)\end{array}$ & $\begin{array}{c}\text { Thickness } \\
\text { (meters) }\end{array}$ \\
\hline 1 & 14.5 & 0.6 \\
2 & 23.3 & 10.3 \\
3 & 6.0 & 2.6 \\
4 & $500.0^{*}$ & \\
\hline
\end{tabular}

- Indicates Fixed Parameter

W JC1500

\begin{tabular}{ccc}
\hline$L \#$ & $\begin{array}{c}\text { Resistivity } \\
(\Omega-\mathrm{m})\end{array}$ & $\begin{array}{c}\text { Thickness } \\
\text { (meters) }\end{array}$ \\
\hline 1 & 47.5 & 0.2 \\
2 & 18.1 & 4.2 \\
3 & 28.3 & 21.7 \\
4 & $500.0^{*}$ & \\
\hline
\end{tabular}


WJNDO

\begin{tabular}{ccc}
\hline$L \#$ & $\begin{array}{c}\text { Resistivity } \\
(\Omega-m)\end{array}$ & $\begin{array}{c}\text { Thickness } \\
\text { (meters) }\end{array}$ \\
\hline 1 & 25.3 & 0.9 \\
2 & 415.9 & 0.9 \\
3 & 28.2 & 41.4 \\
4 & $500.0^{*}$ & \\
\hline
\end{tabular}

- Indicates Fixed Parameter

WJND80

\begin{tabular}{ccc}
\hline$L \#$ & $\begin{array}{c}\text { Resistivity } \\
(\Omega-m)\end{array}$ & $\begin{array}{c}\text { Thickness } \\
\text { (meters) }\end{array}$ \\
\hline 1 & 113.0 & 0.2 \\
2 & 24.8 & 3.0 \\
3 & 66.8 & 10.2 \\
4 & 10.2 & 10.8 \\
5 & $500.0^{*}$ & \\
\hline
\end{tabular}

W JEFF

\begin{tabular}{ccc}
\hline$L \#$ & $\begin{array}{c}\text { Resistivity } \\
(\Omega-m)\end{array}$ & $\begin{array}{c}\text { Thickness } \\
\text { (meters) }\end{array}$ \\
\hline 1 & 15.8 & 3.8 \\
2 & 74.5 & 38.7 \\
3 & $500.0^{*}$ & \\
\hline
\end{tabular}

- Indicates Fixed Parameter 

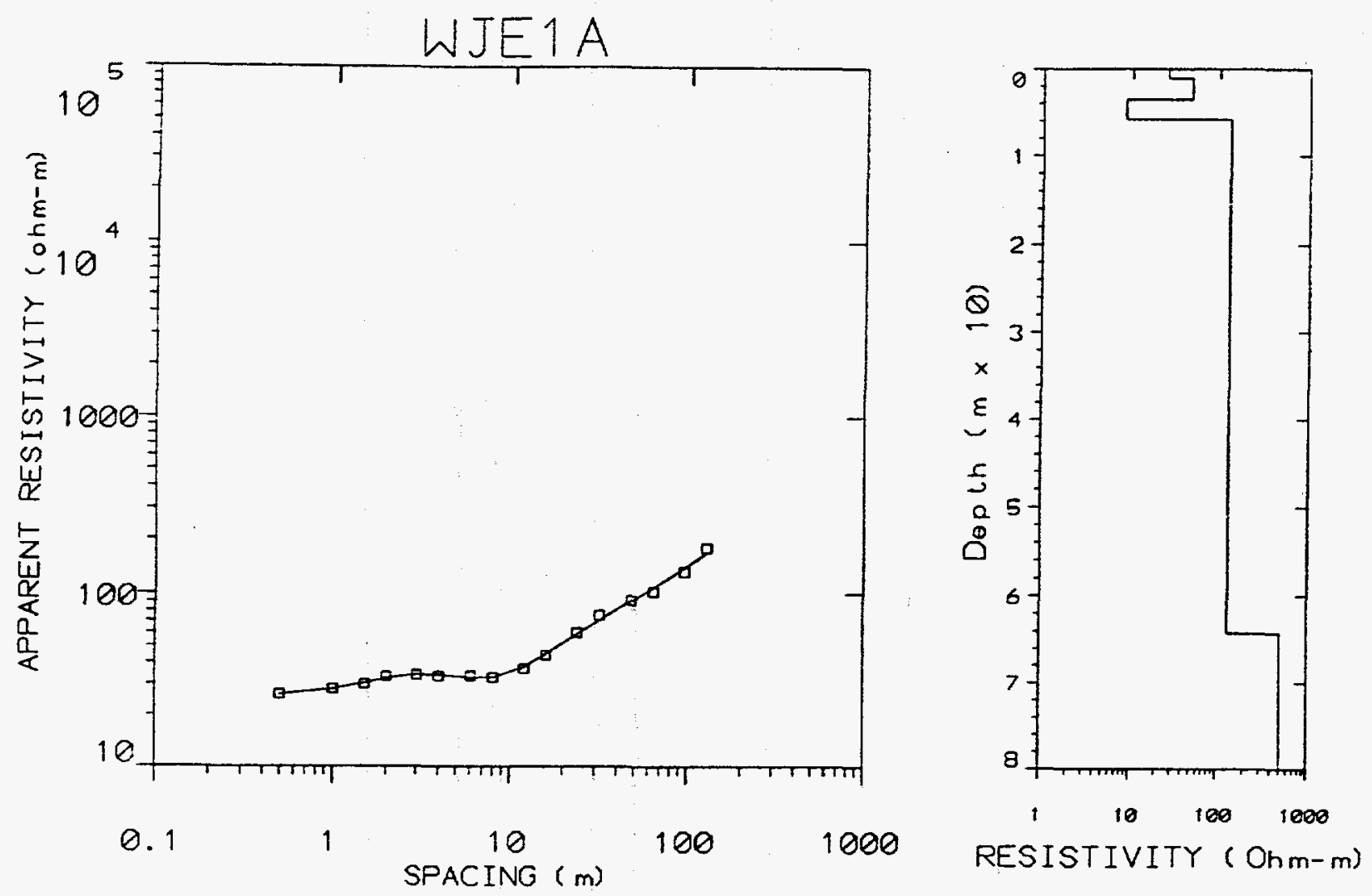

Figure A.1.
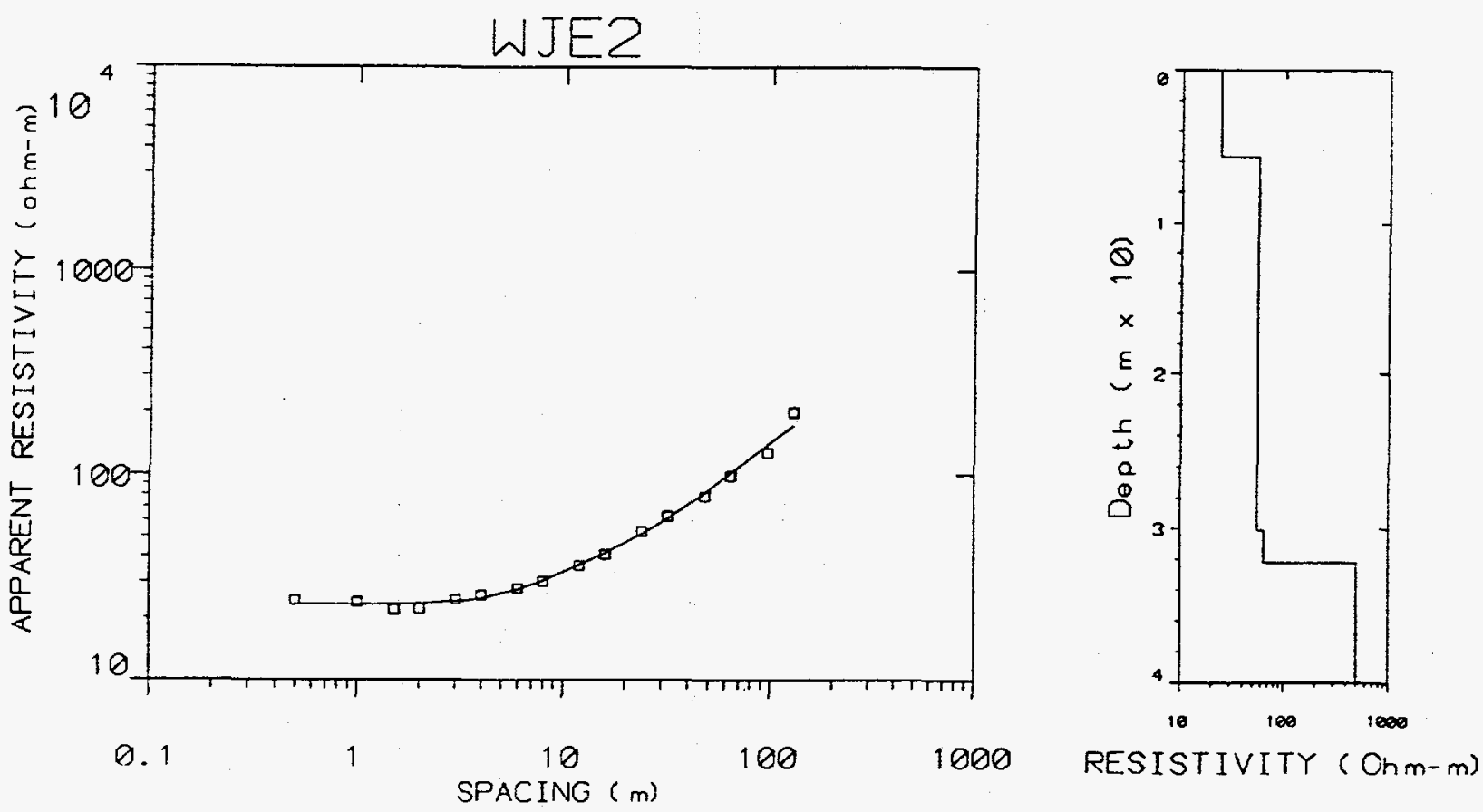

Figure A.2. 


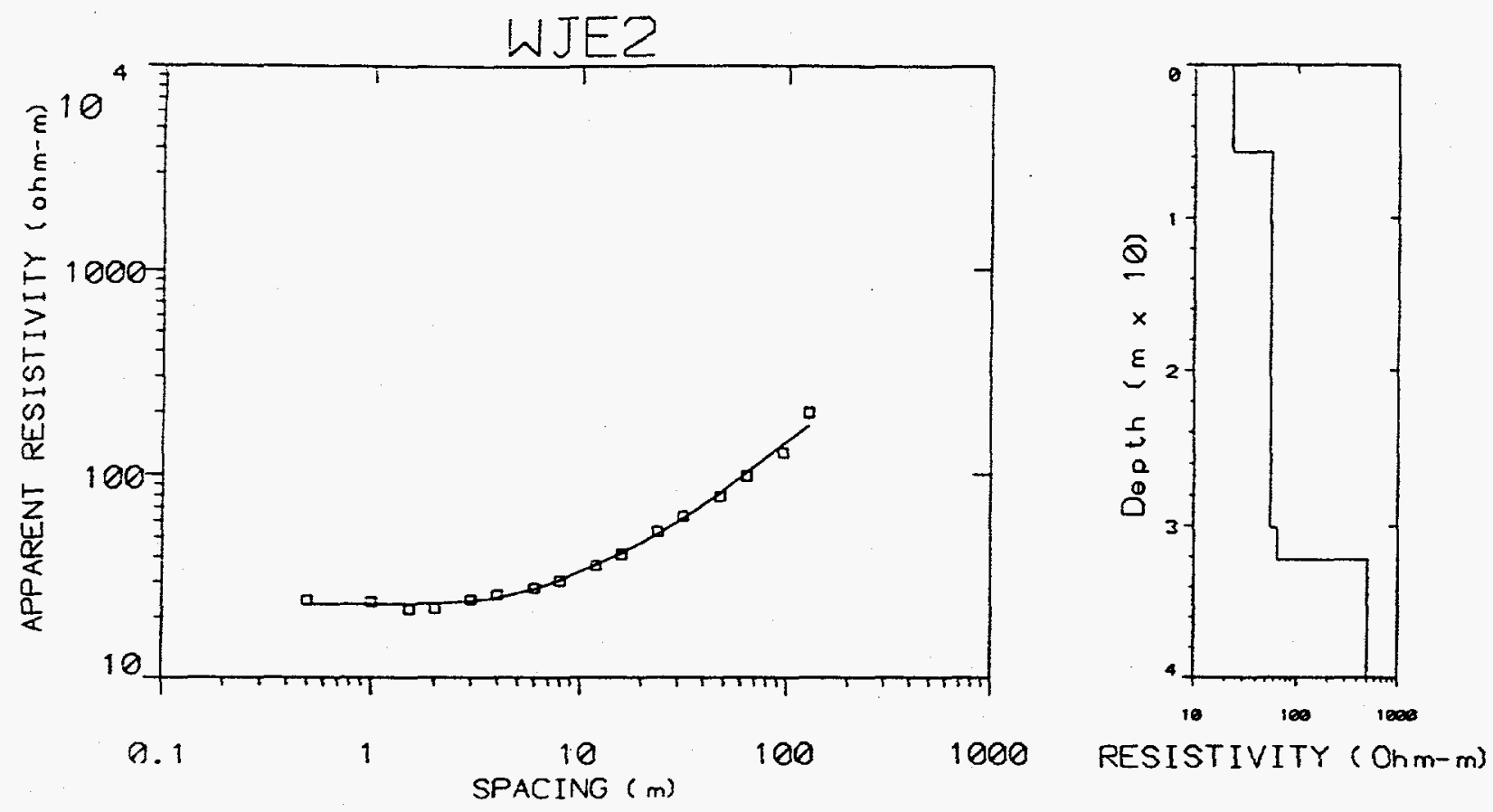

Figure A.3.

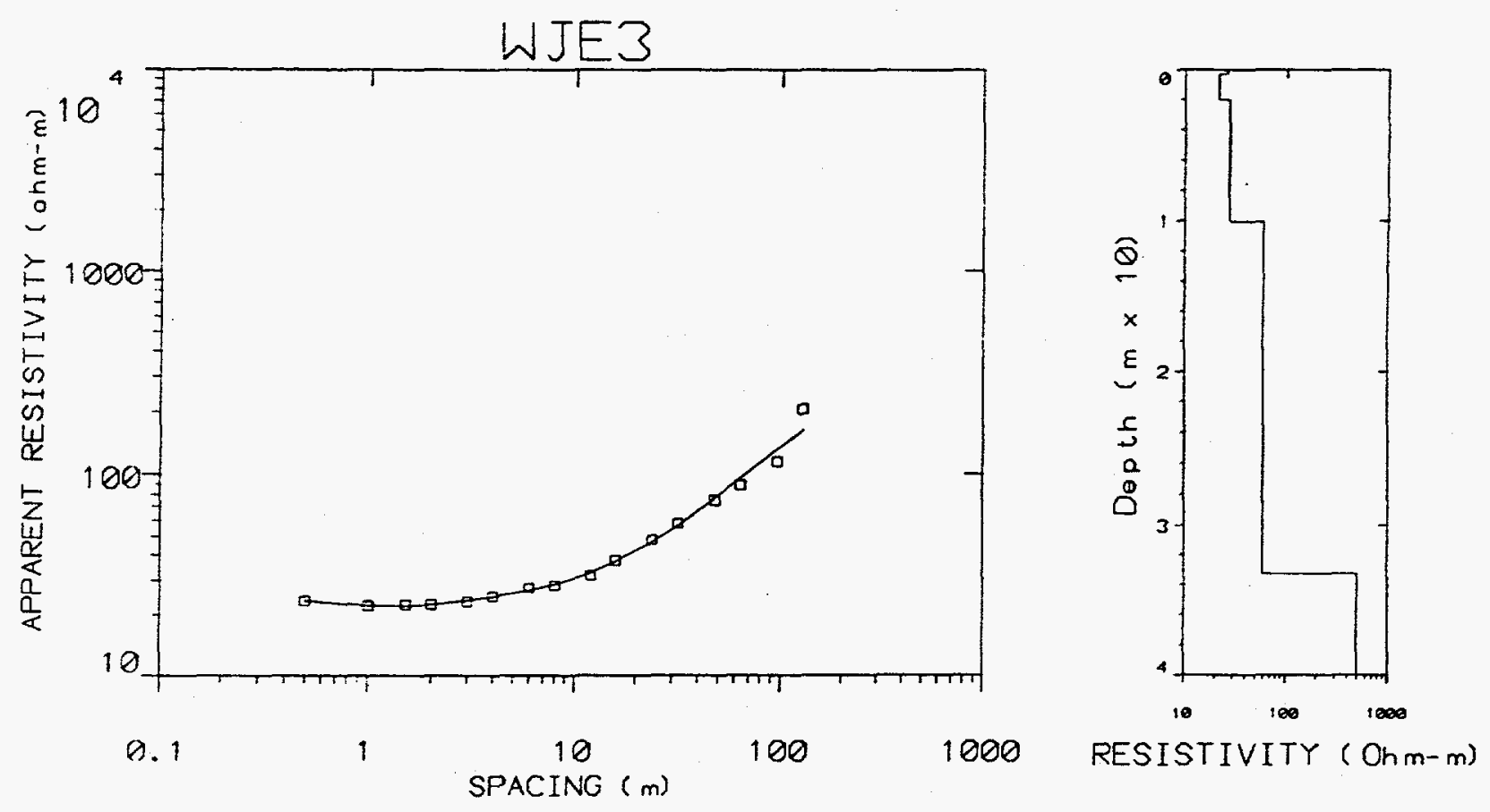

Figure A.4. 
90

WJE4

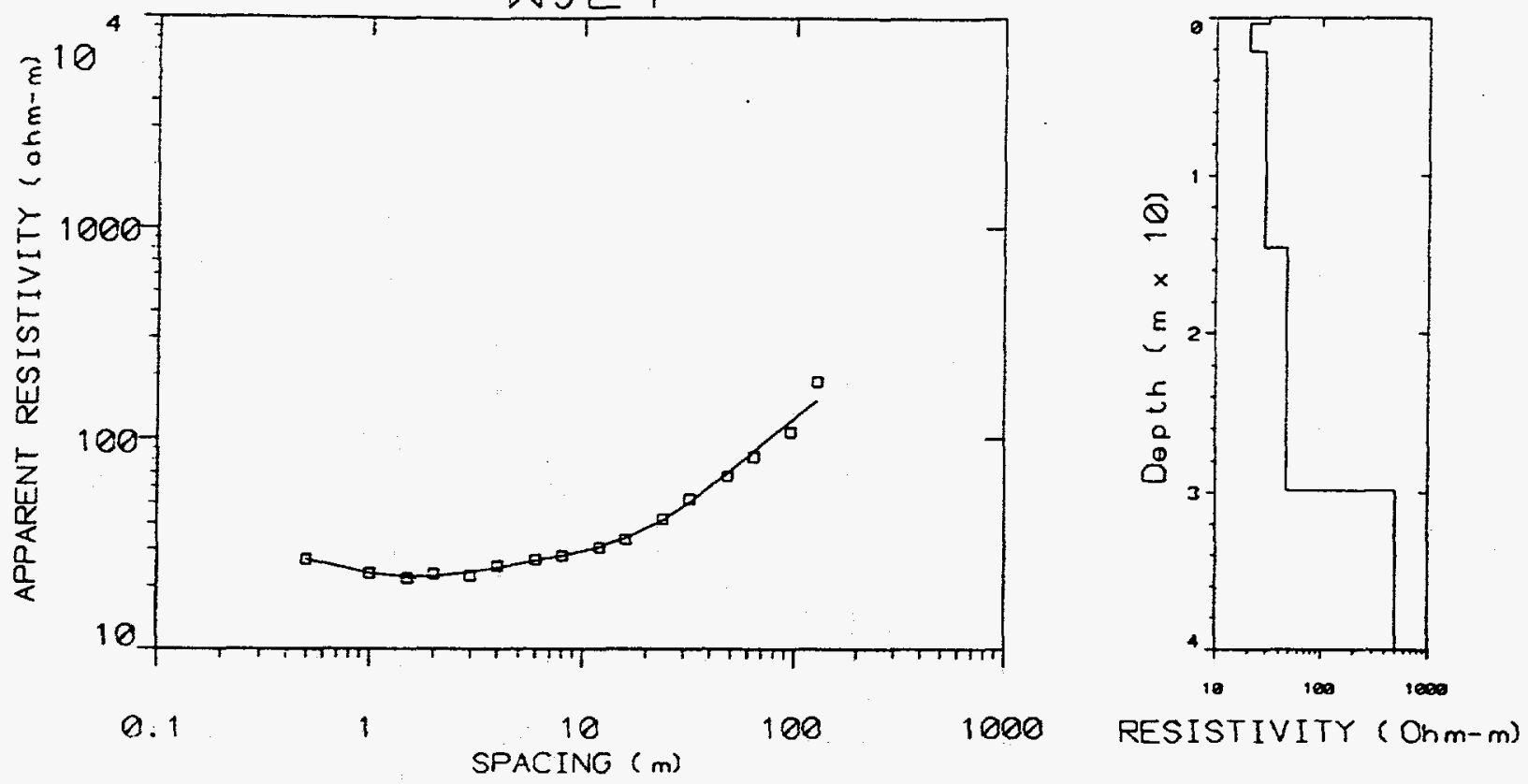

Figure A.5.

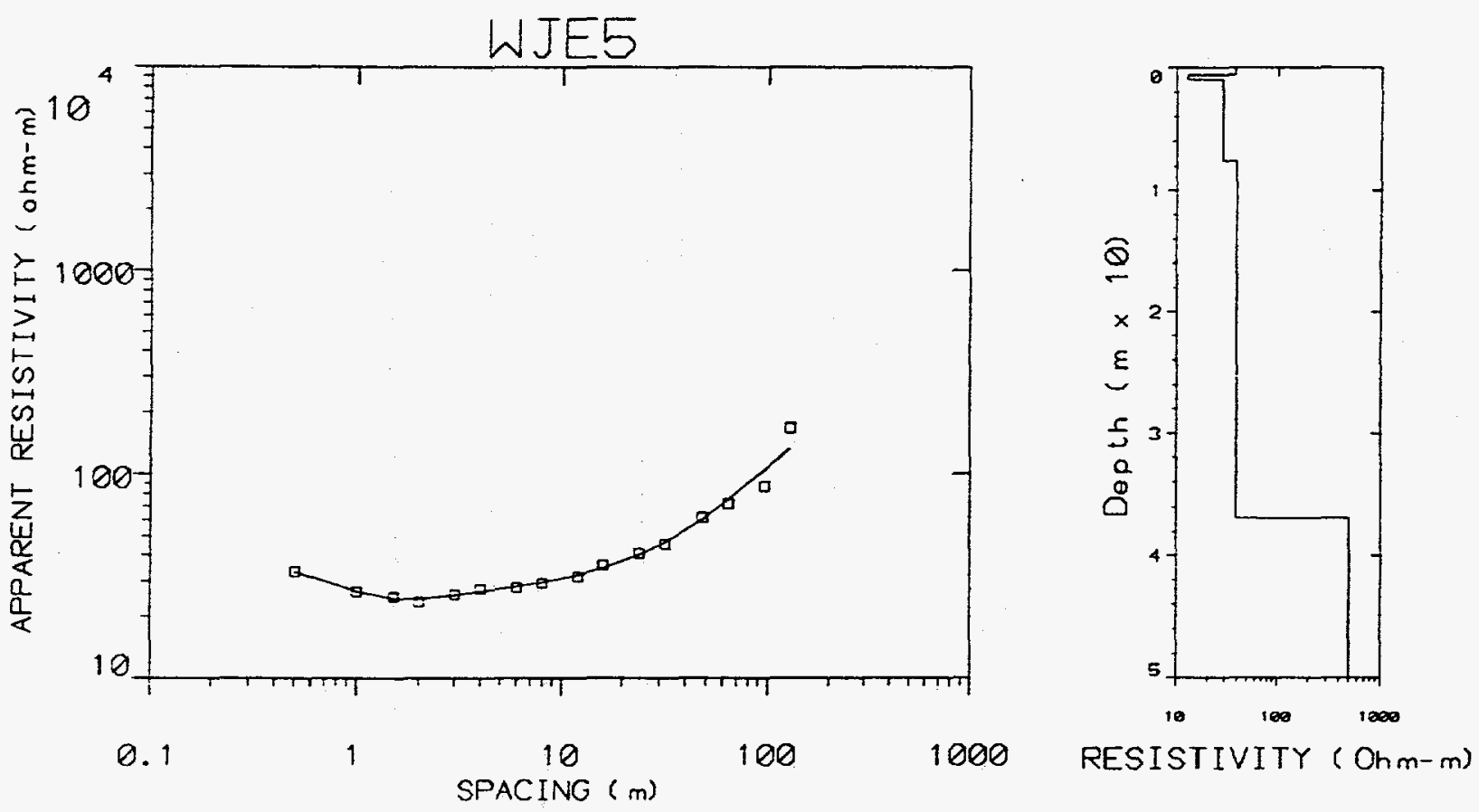

Figure A.6. 


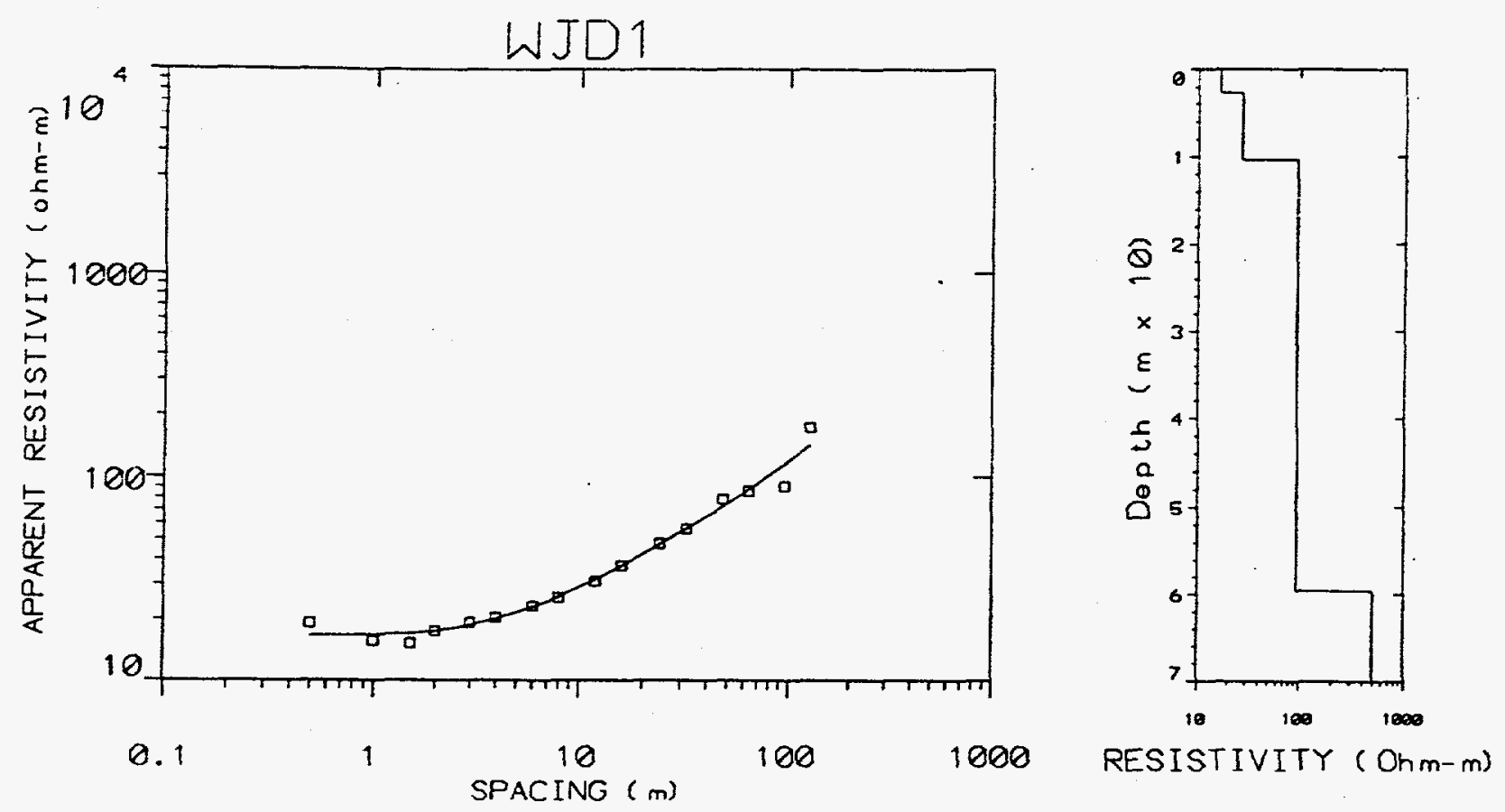

Figure A.7.
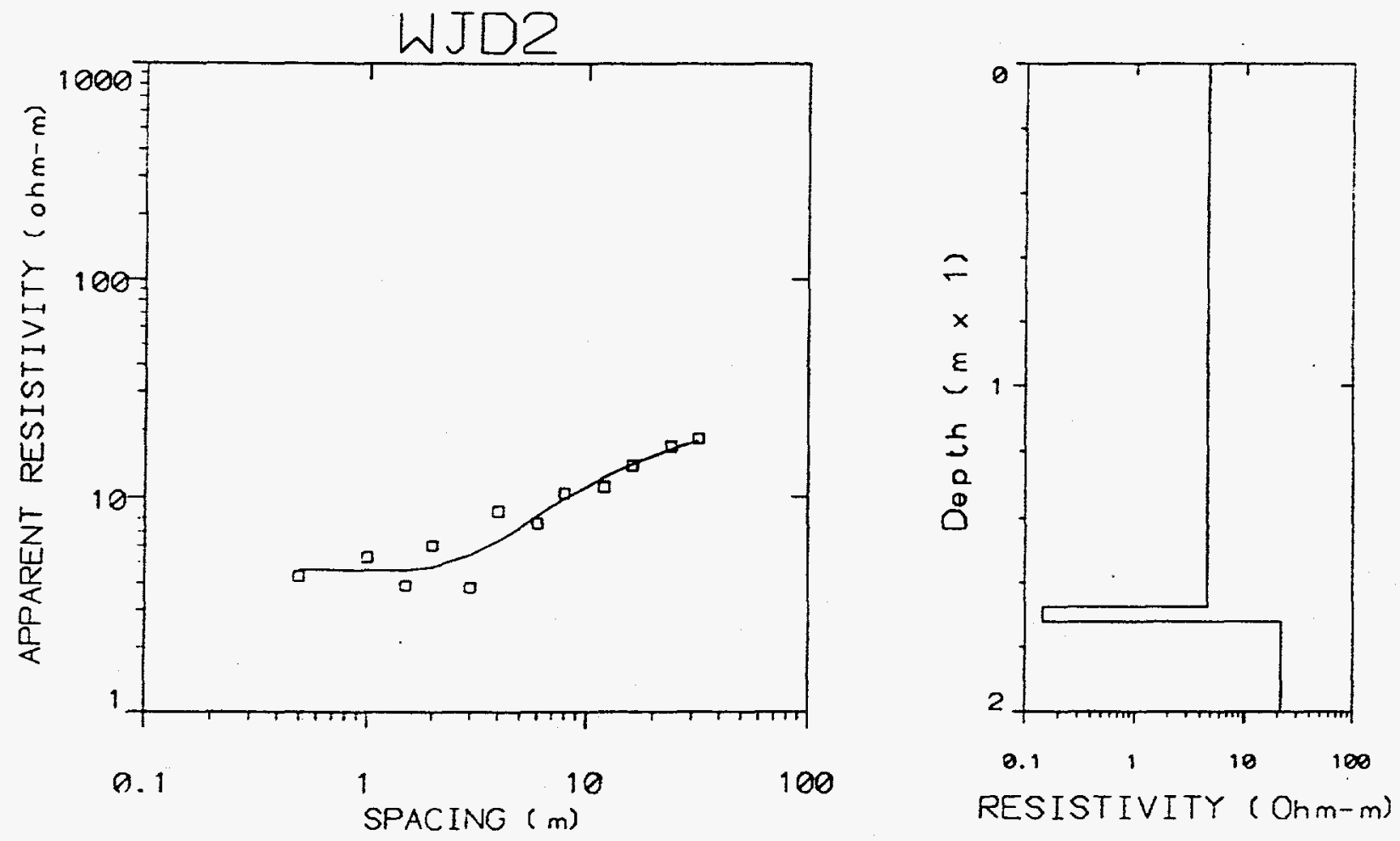

Figure A.8. 

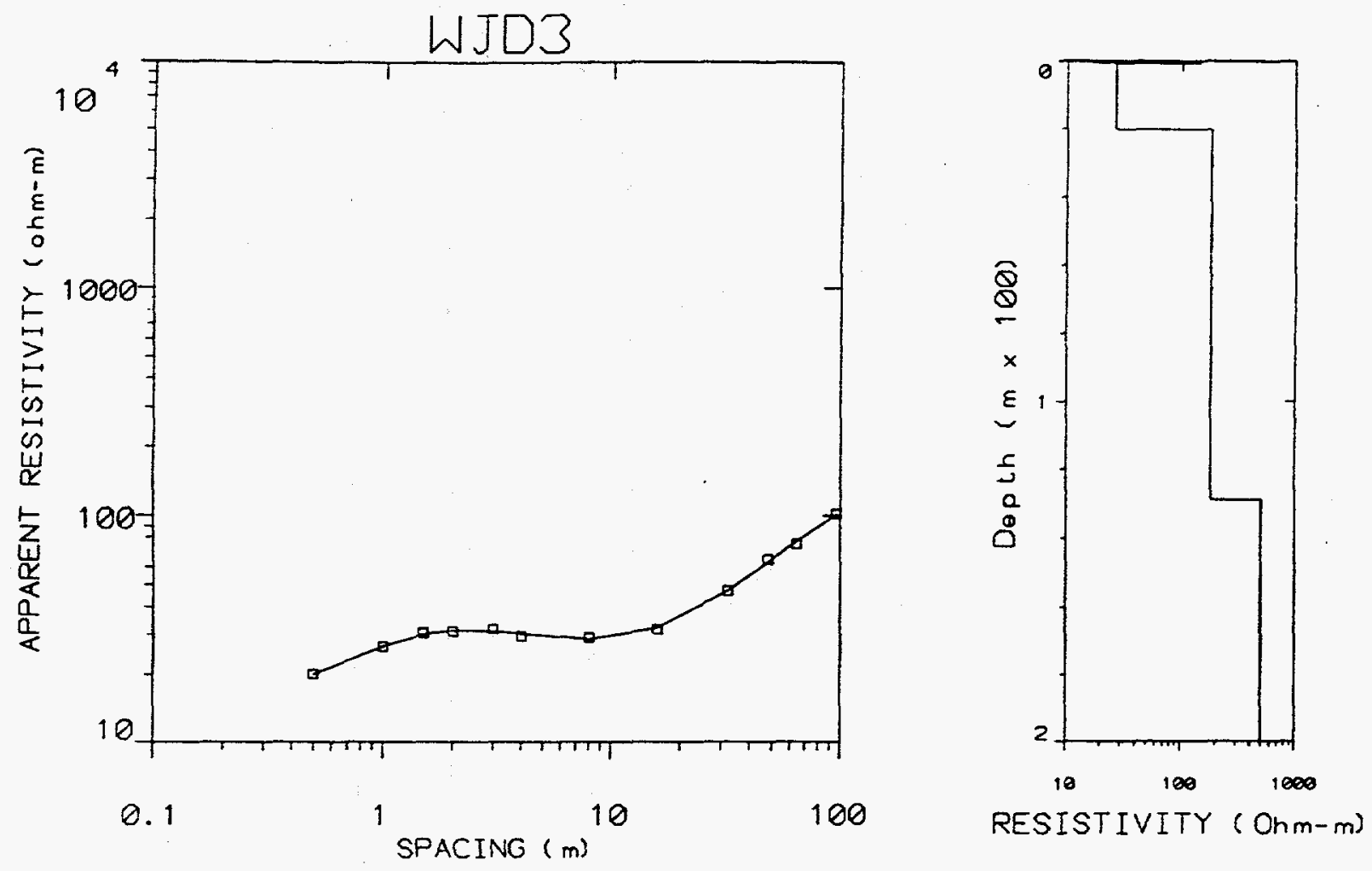

Figure A.9.
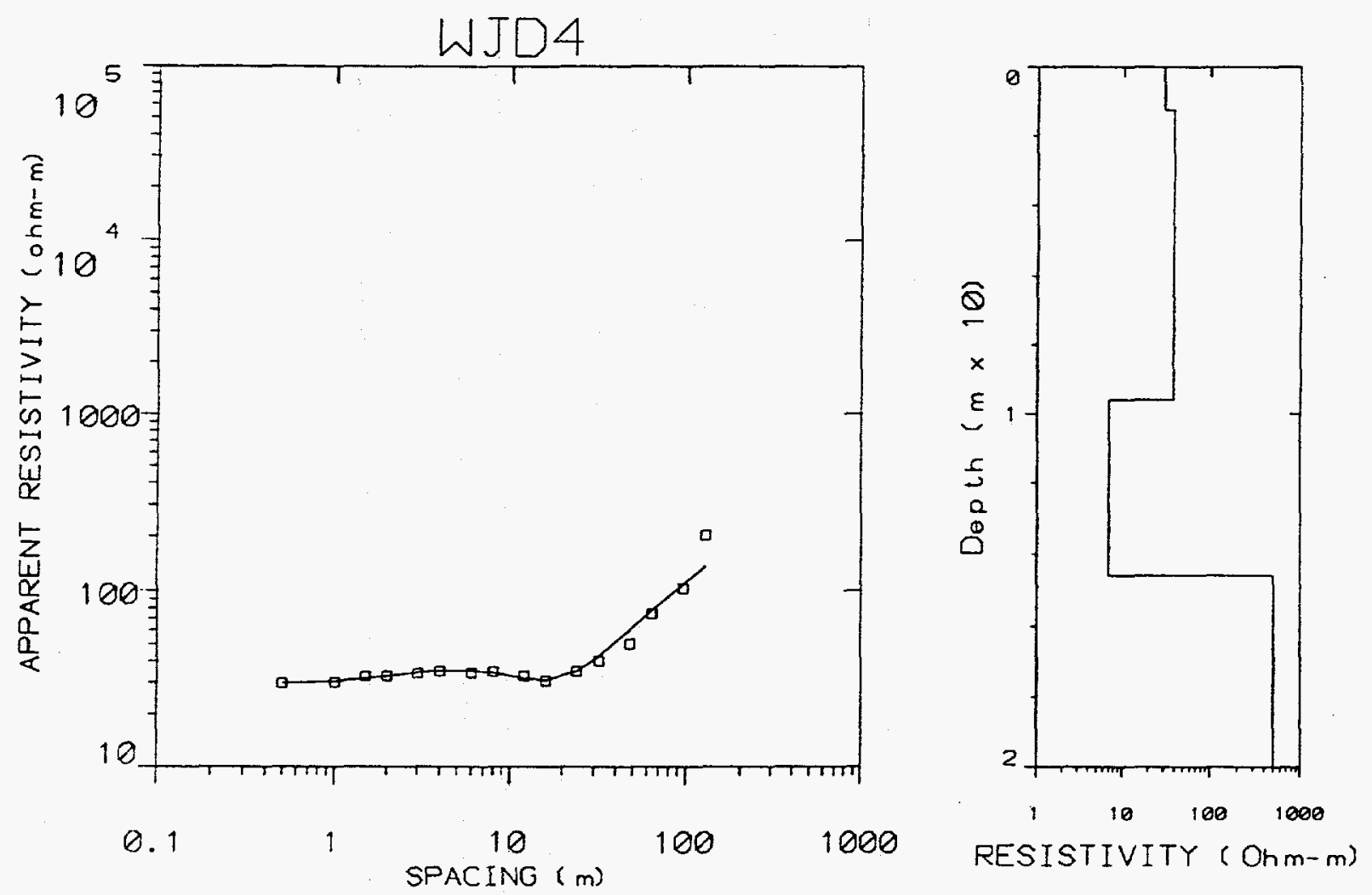

Figure A.10. 

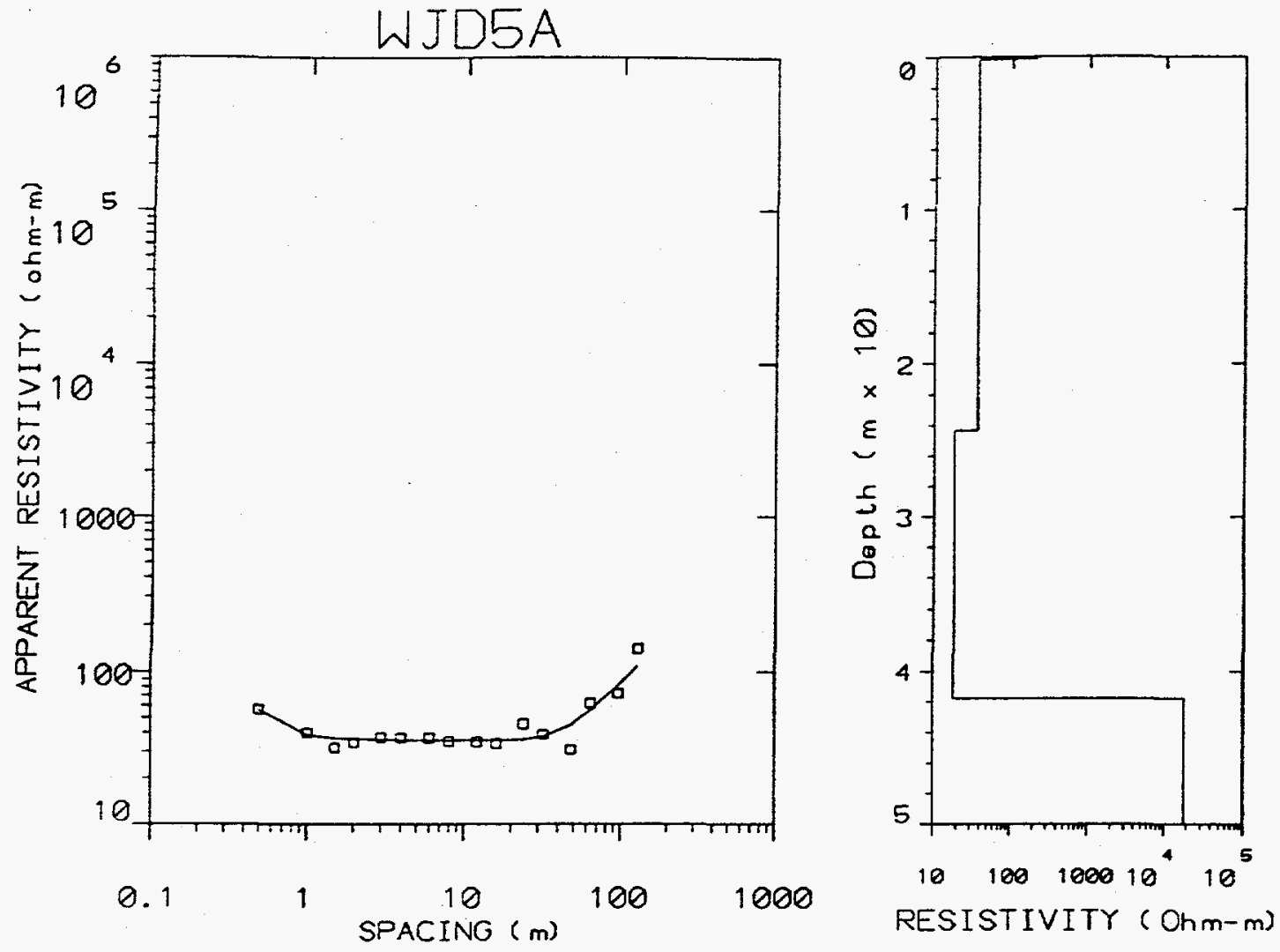

Figure A.11.
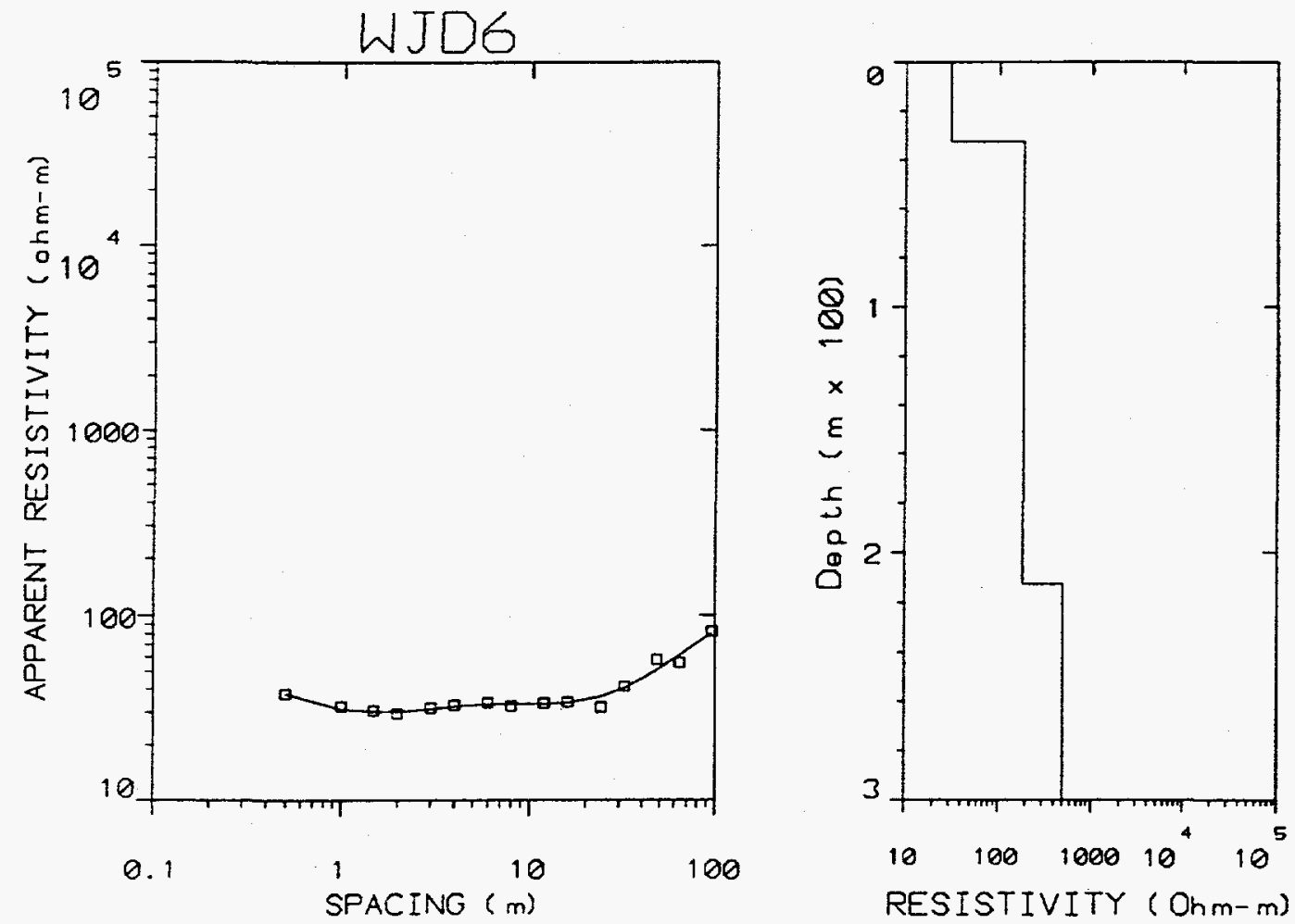

Figure A.12. 

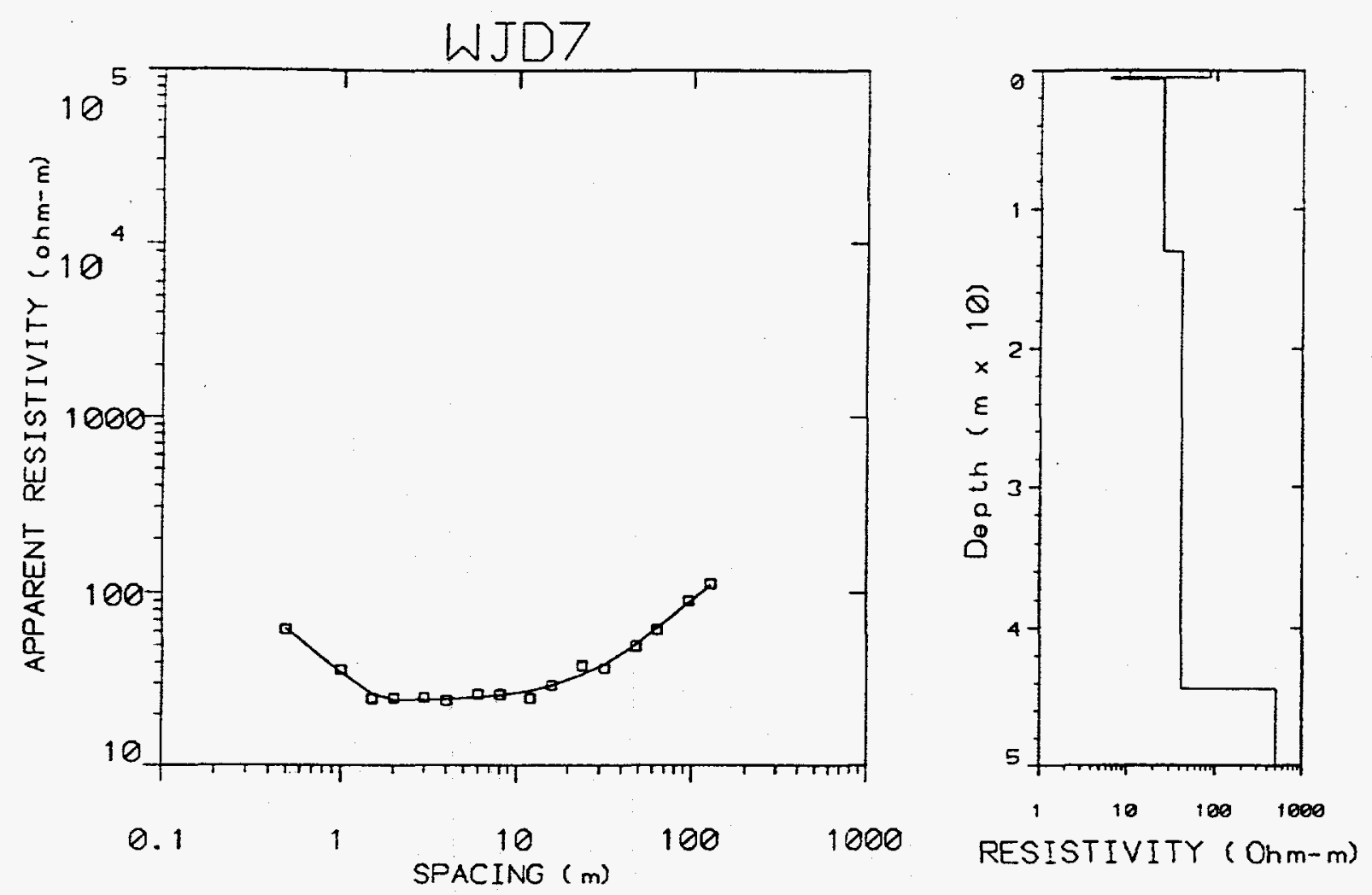

Figure A.13.
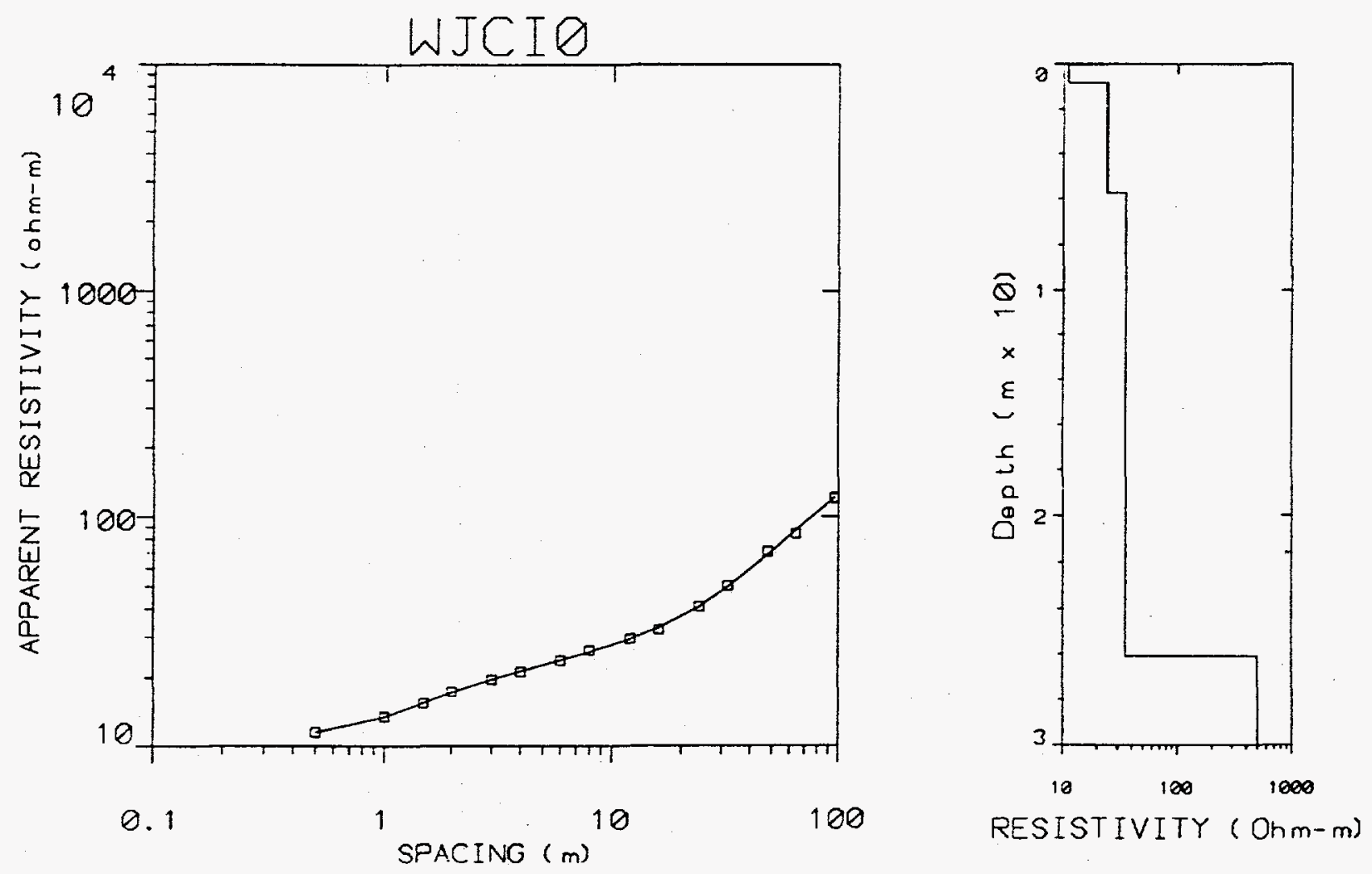

Figure A.14. 

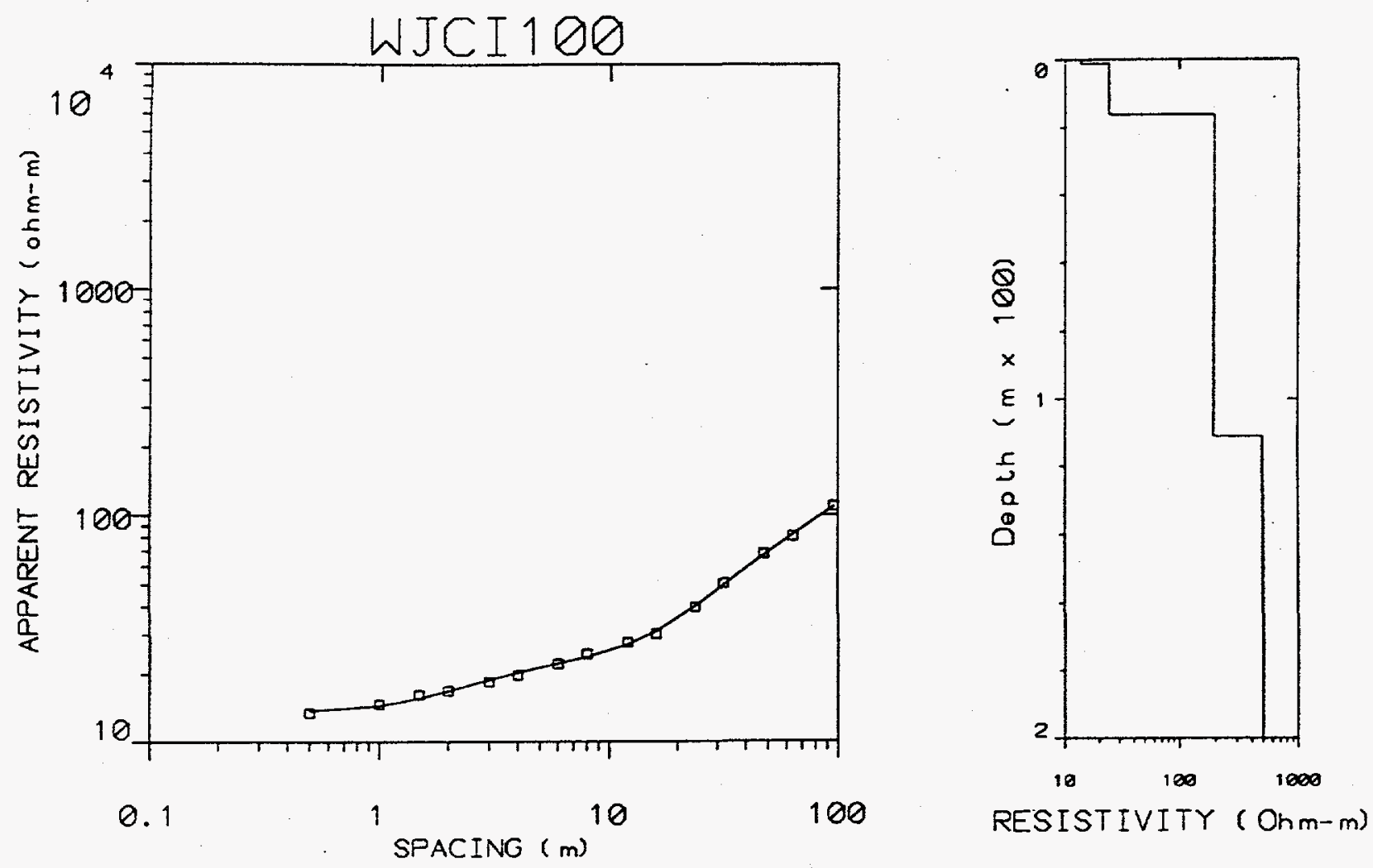

Figure A.15.
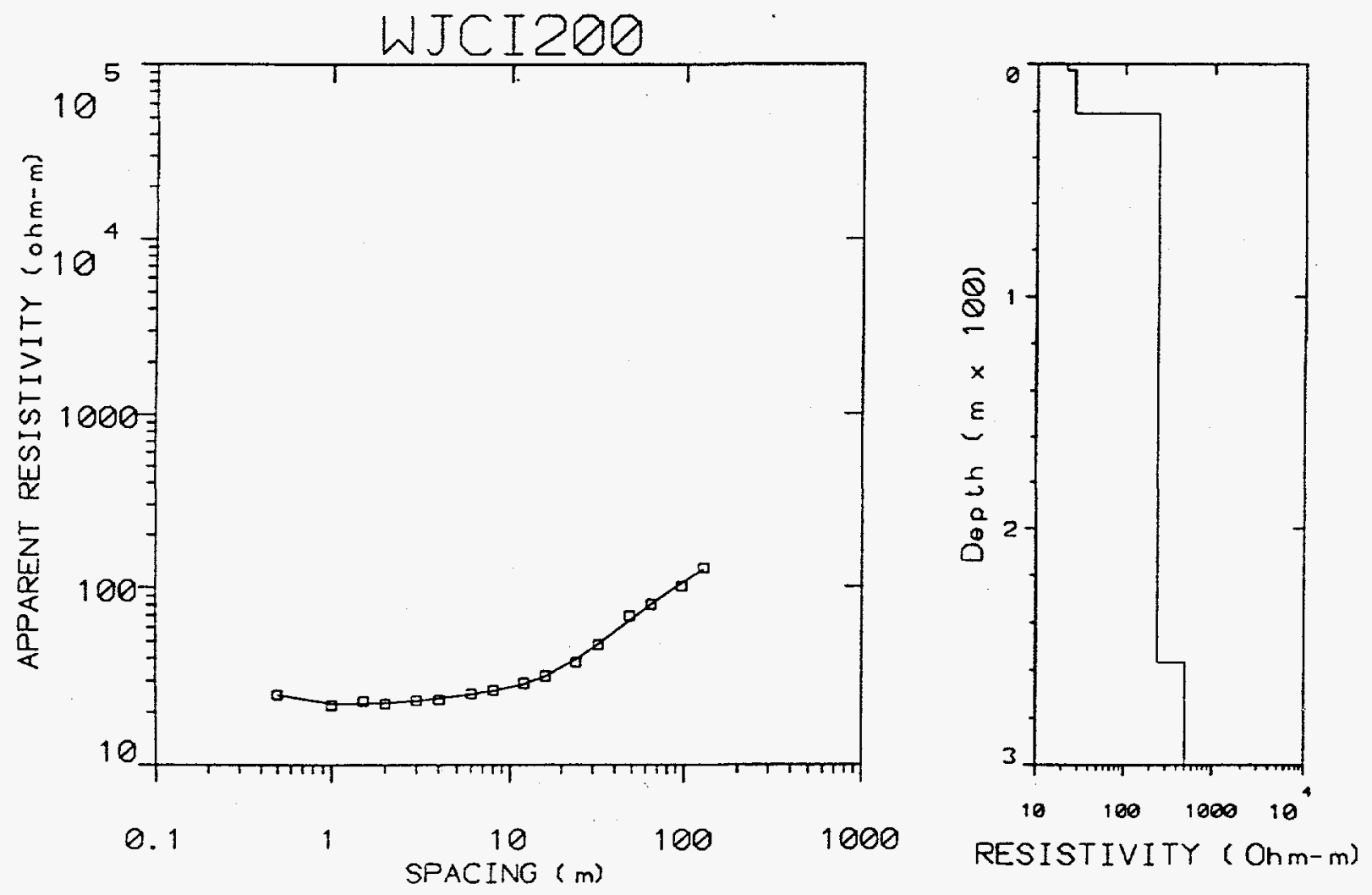

Figure A.16. 


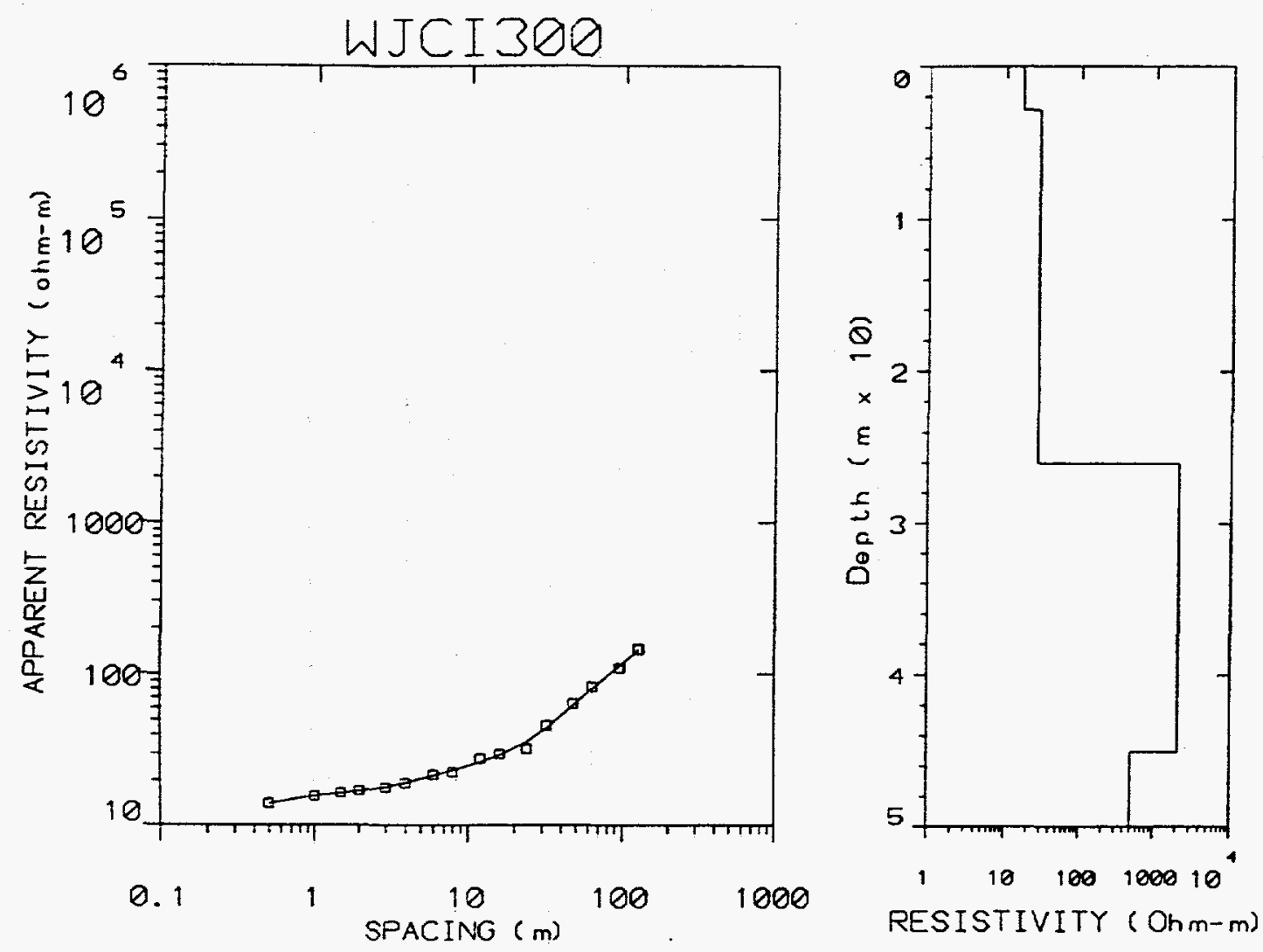

Figure A.17.
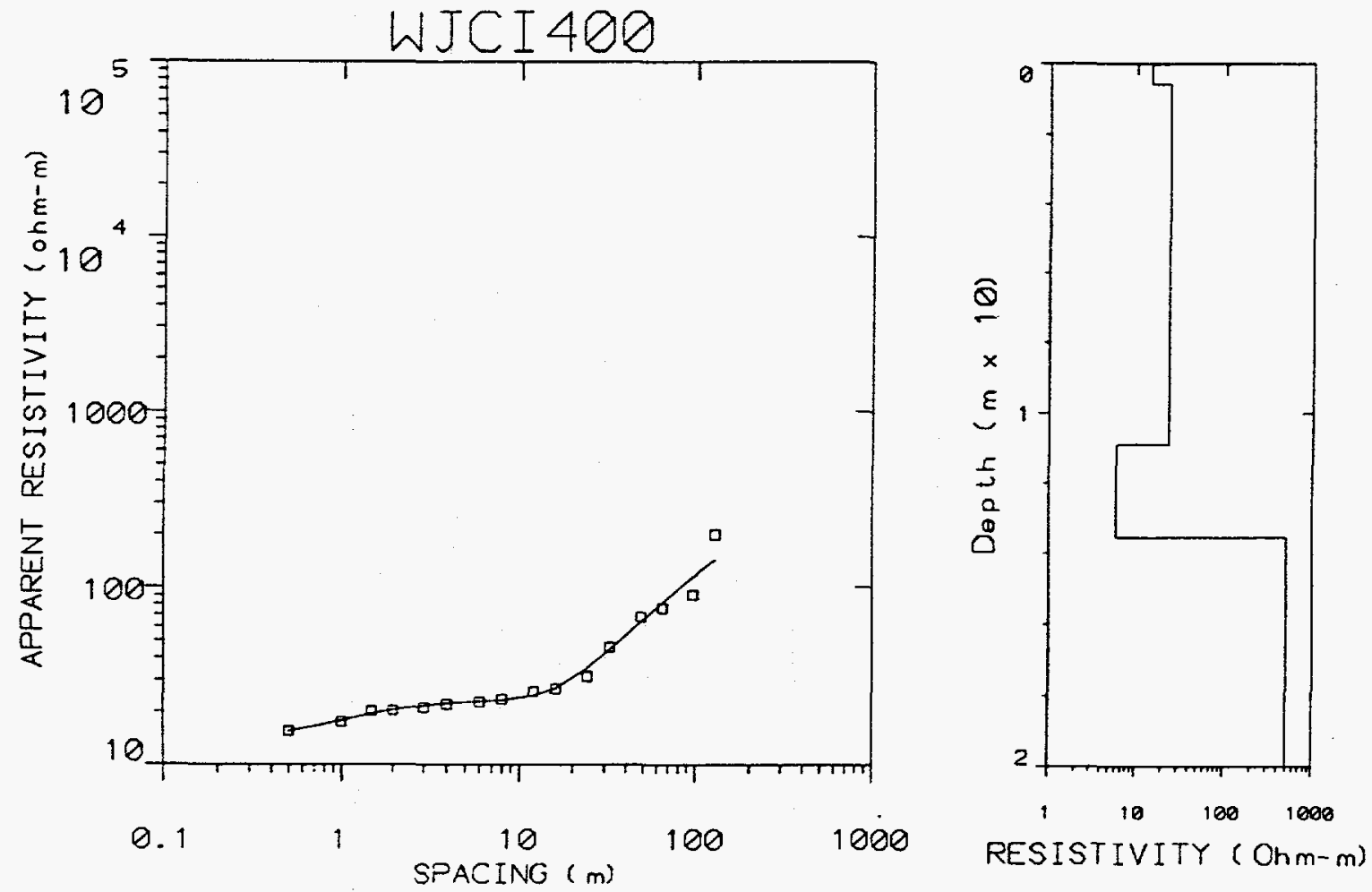

Figure A.18. 


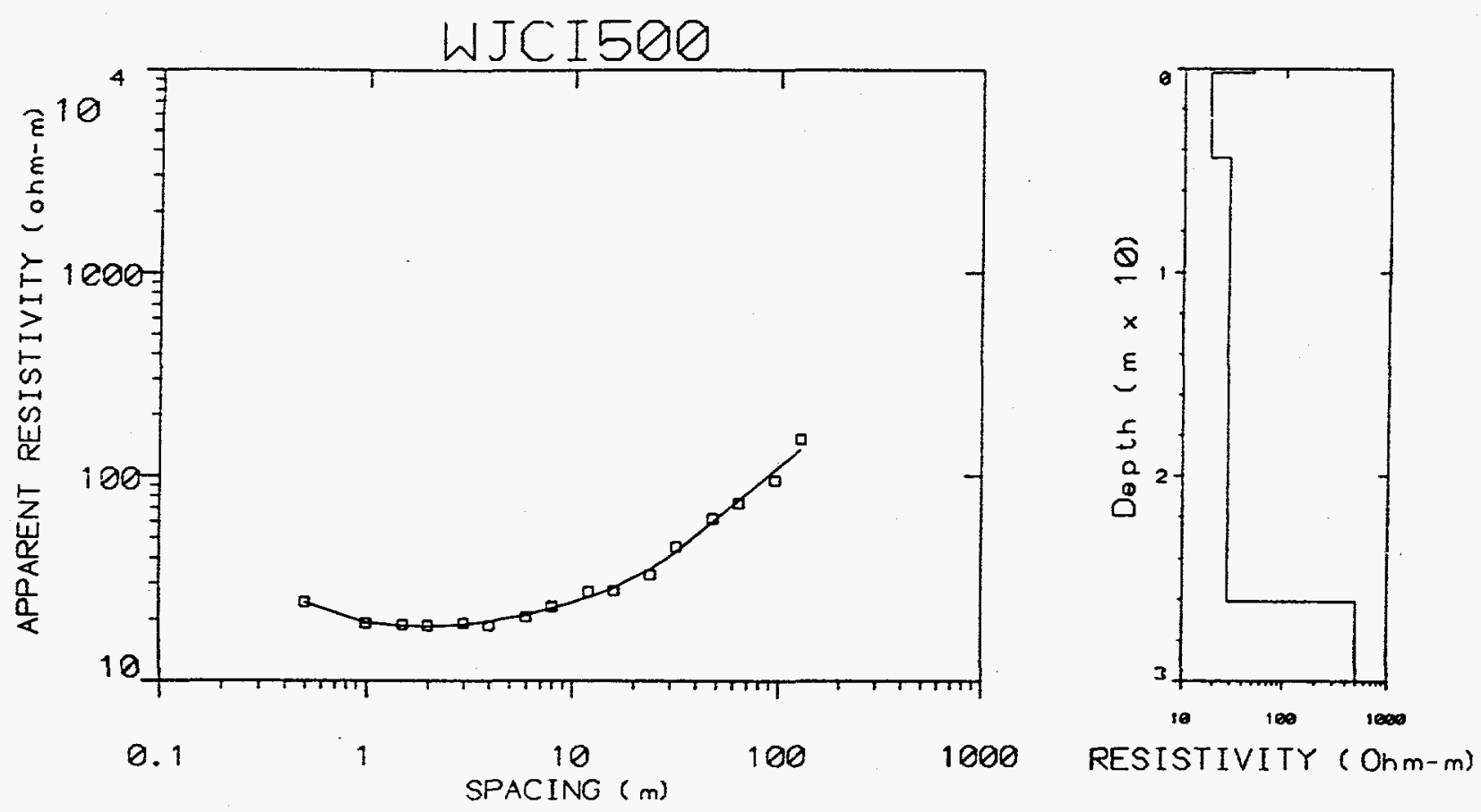

Figure A.19.

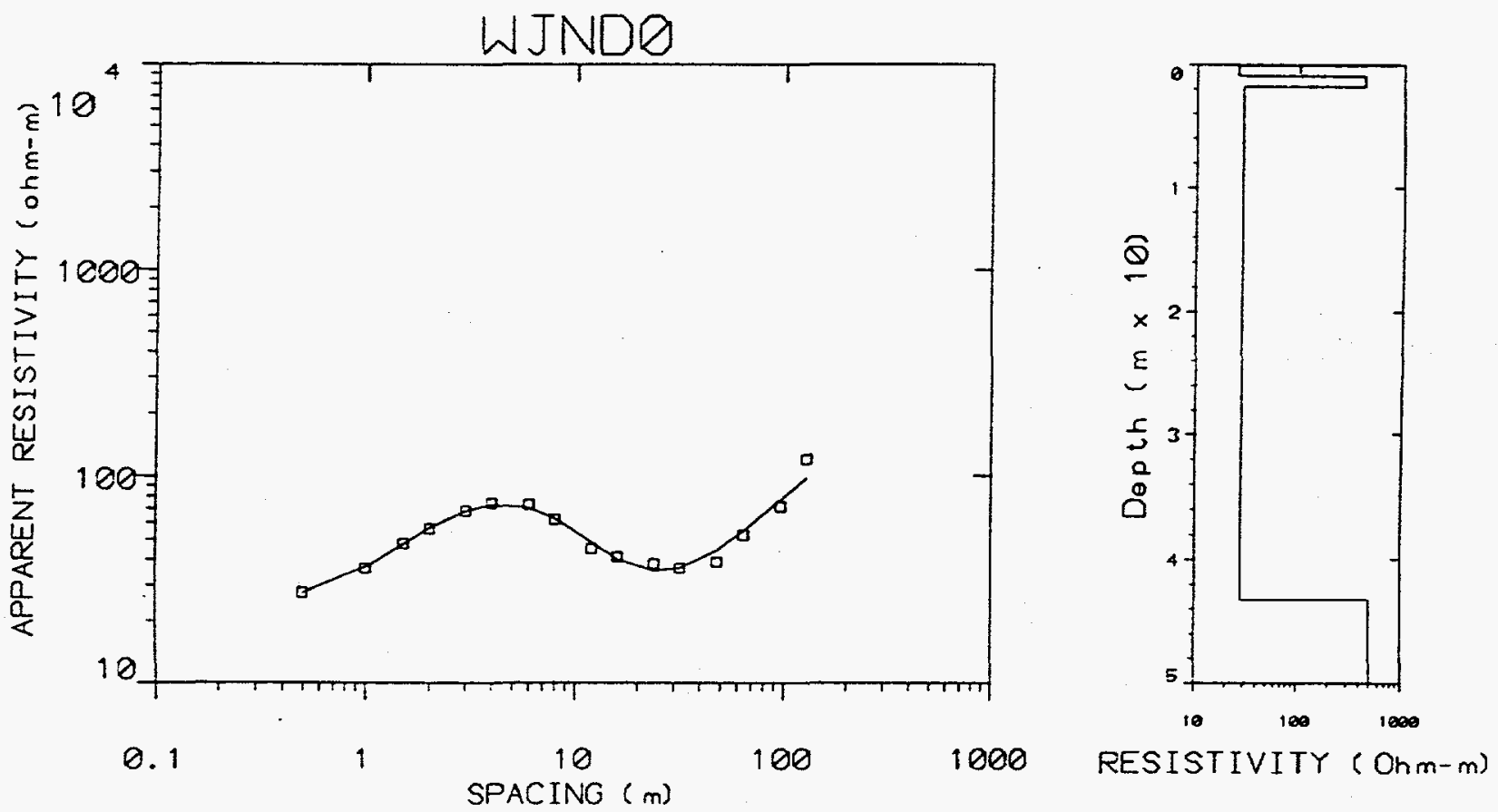

Figure A.20. 


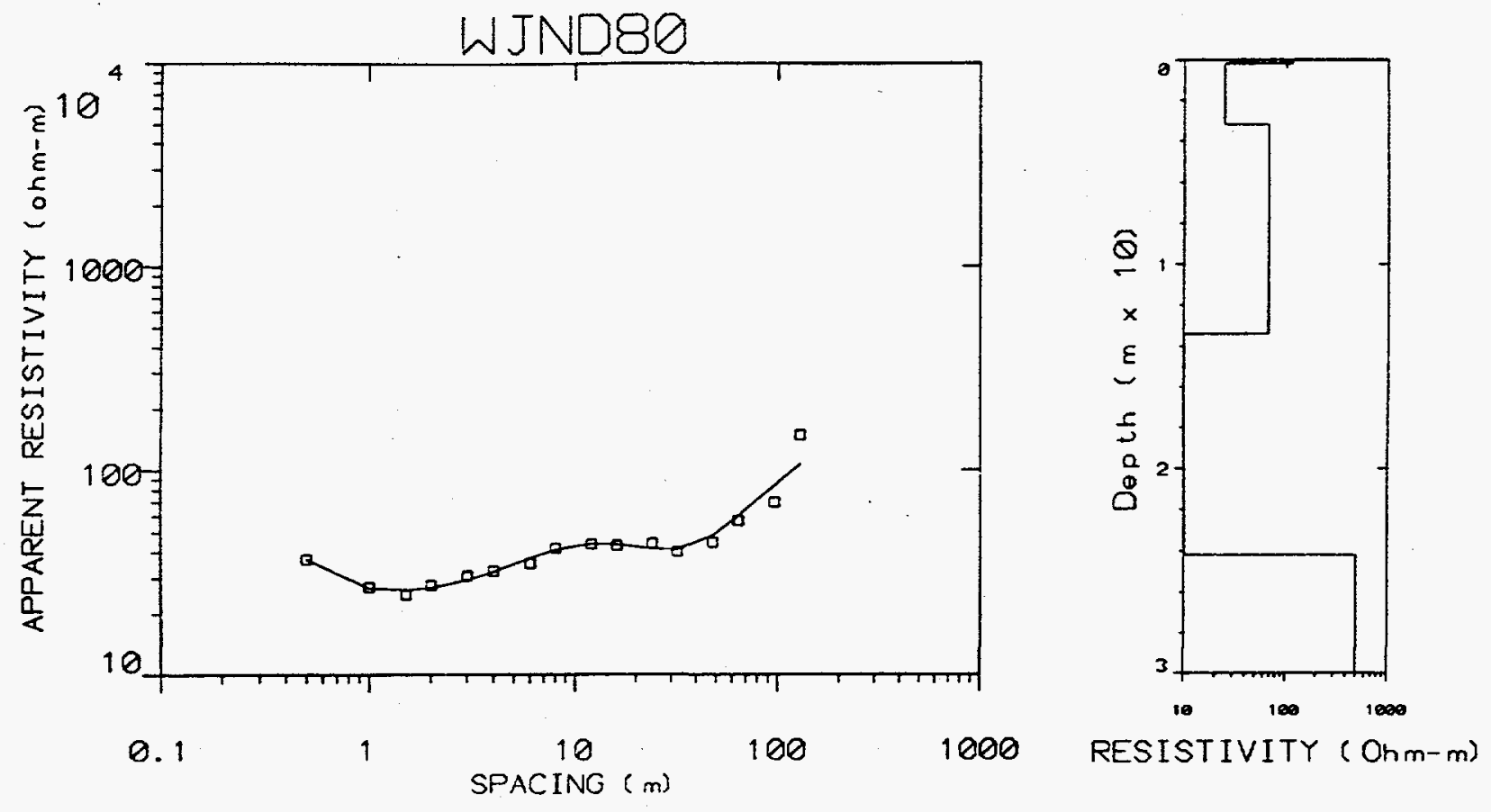

Figure A.21.
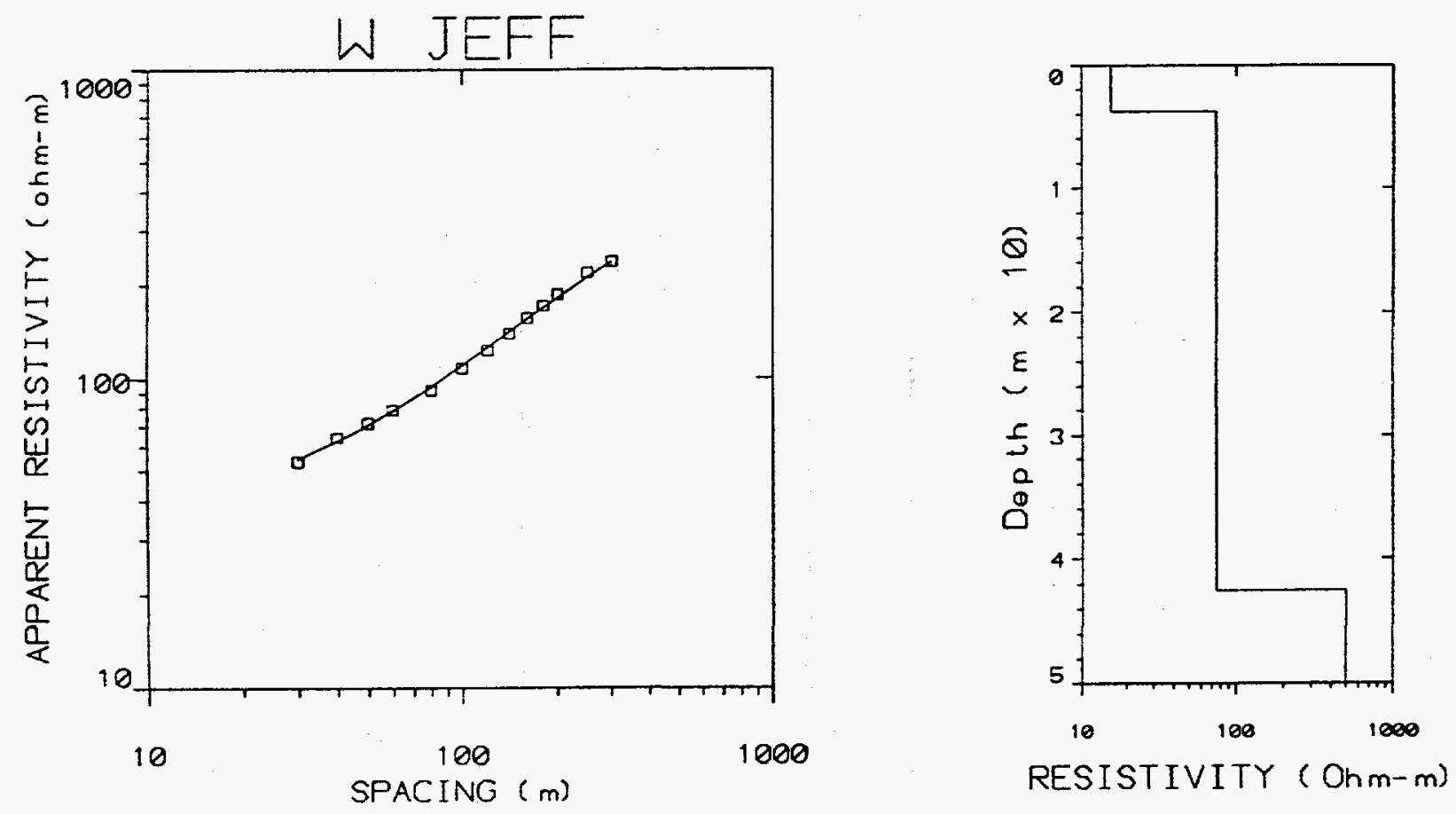

Figure A.22. 
APPENDIX B:

COORDINATES OF GROUND-PENETRATING-RADAR

PROFILES AT BATTELLE WEST JEFFERSON 
West Jefferson Filter Bed Ground-Penetrating Radar Profile Line Coordinates

\begin{tabular}{|c|c|c|c|c|}
\hline \multirow{2}{*}{ Profile \# } & \multicolumn{2}{|c|}{ Start Coordinates } & \multicolumn{2}{|c|}{ End Coordinates } \\
\cline { 2 - 5 } & North & East & North & East \\
\hline 1 & 480 & 620 & 480 & 900 \\
2 & 500 & 870 & 1340 & 900 \\
3 & 700 & 680 & 900 & 680 \\
4 & 700 & 660 & 900 & 660 \\
5 & 670 & 712 & 787 & 743 \\
6 & 787 & 743 & 947 & 660 \\
7 & 1040 & 760 & 740 & 790 \\
8 & 740 & 790 & 500 & 790 \\
9 & 500 & 840 & 560 & 840 \\
10 & 560 & 840 & 890 & 840 \\
11 & 890 & 840 & 1100 & 840 \\
12 & 850 & 960 & 787 & 743 \\
13 & 1100 & 880 & 900 & 880 \\
14 & 900 & 880 & 700 & 880 \\
15 & 810 & 880 & 810 & 960 \\
16 & 500 & 660 & 500 & 740 \\
17 & 450 & 845 & 510 & 860 \\
18 & 695 & 900 & 705 & 830 \\
19 & 695 & 890 & 760 & 900 \\
20 & 700 & 840 & 800 & 950 \\
21 & 790 & 940 & 1340 & 890 \\
\hline
\end{tabular}




\section{APPENDIX C:}

CPT SOUNDINGS 
APPLIED RESEARCH ASSOCIATES. INC.

$09 / 20 / 95$ North $500 \quad$ East $675 \quad$ Elevation
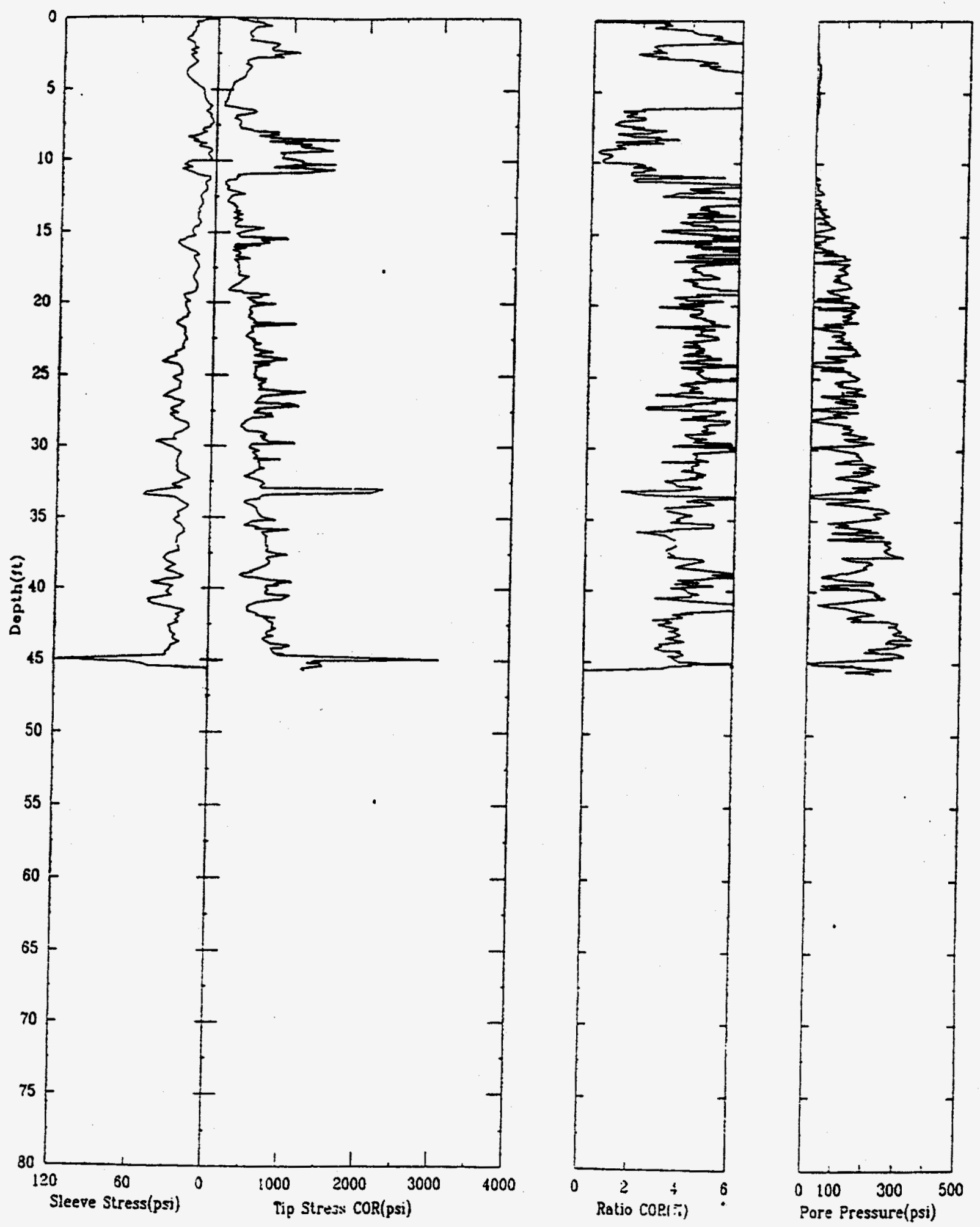

Figure C.1a. 
CPT-01

APPLIED RESEARCH ASSOCIATES, INC.

$09 / 20 / 95$ North 500 East 675 Elevation

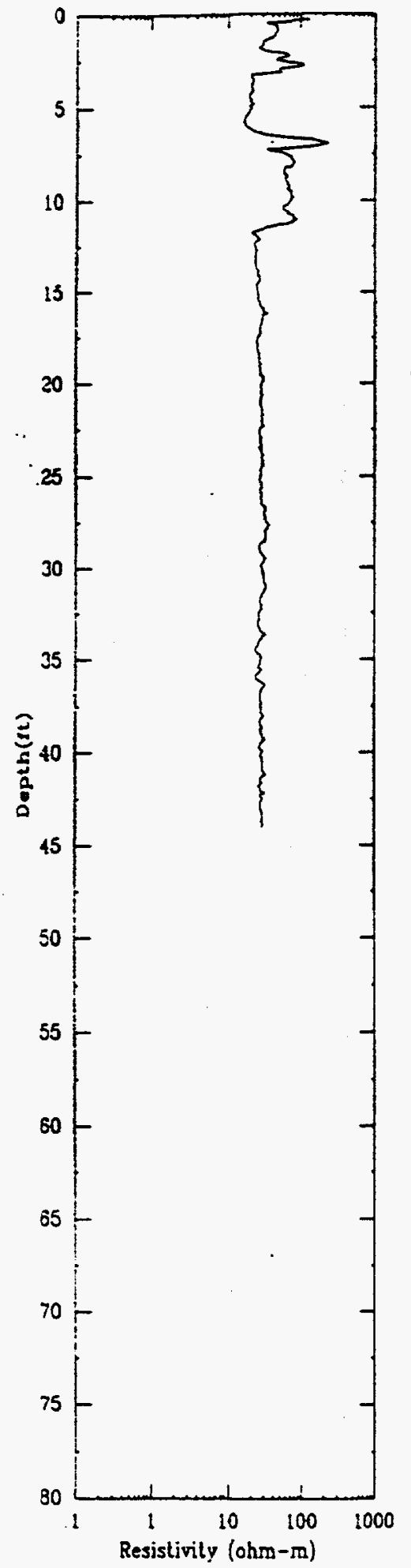

Figure C.1b. 

Yorth 498 East $730 \quad$ Elevation
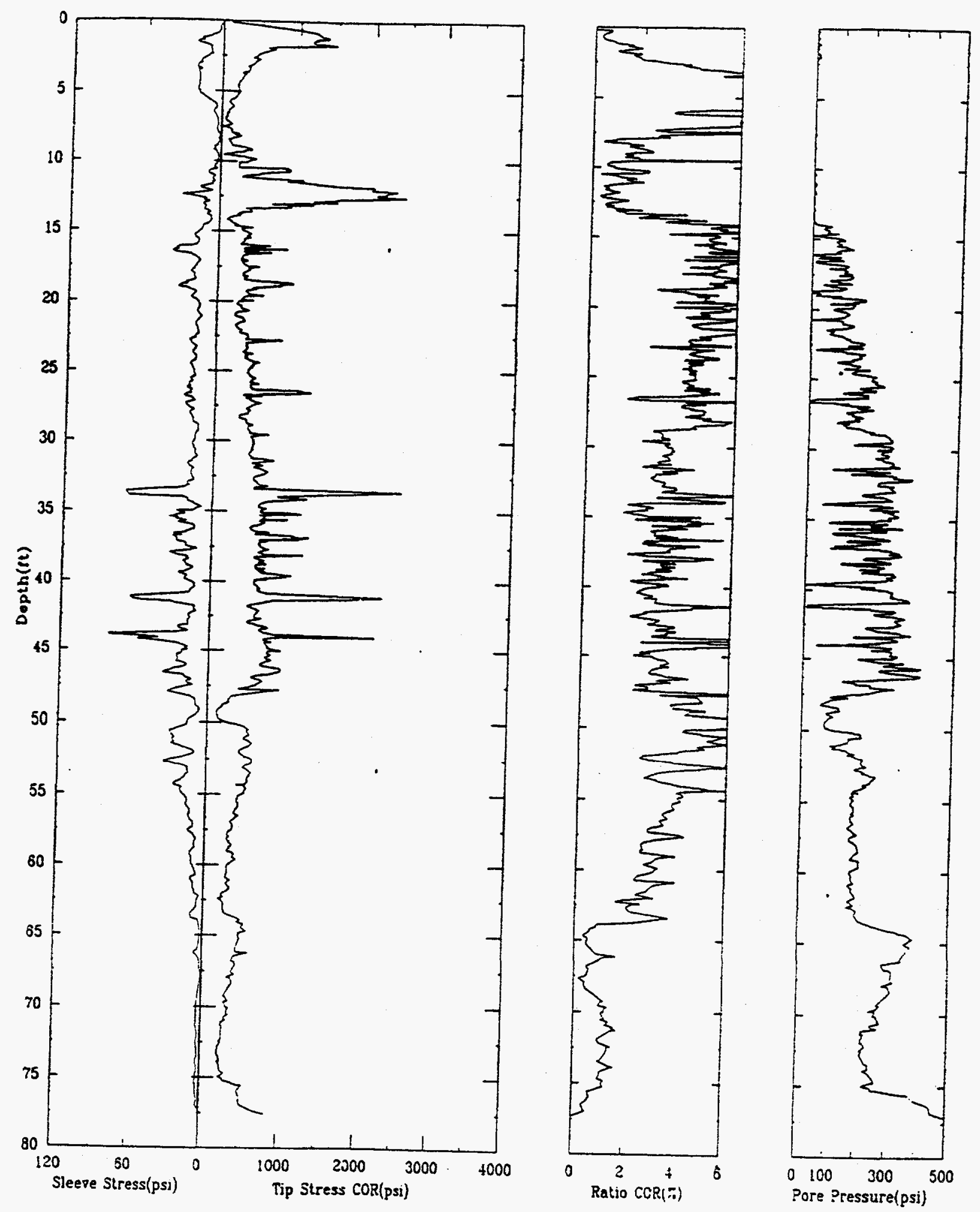

Figure C.2a. 

North $498 \quad$ East $730 \quad$ Elevation

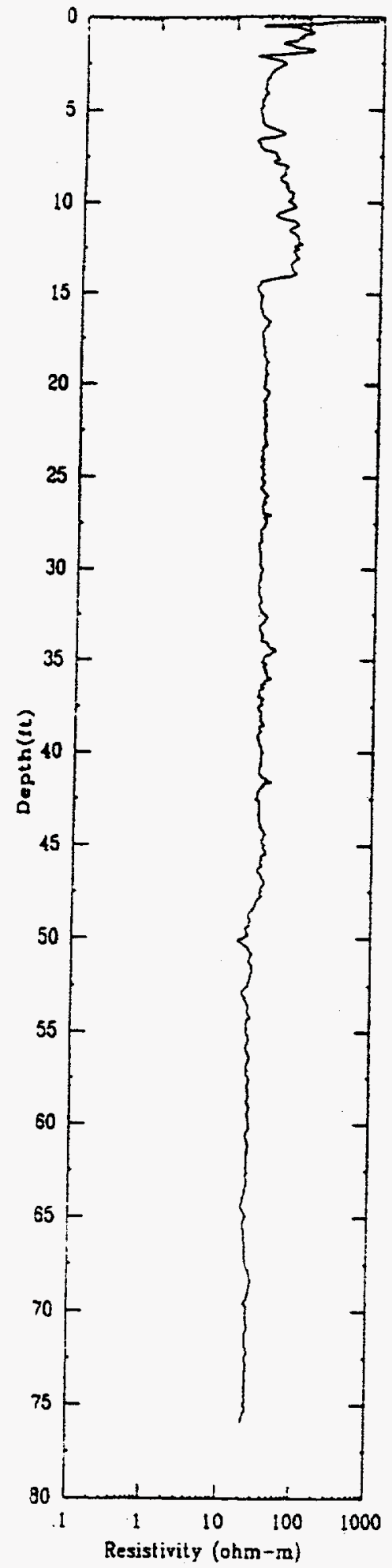

Figure C.2b. 
CPT -03

APPLIED RESEARCH ASSOCIATES, INC.

$09 / 20 / 95$

North 760 East 900 Elevation
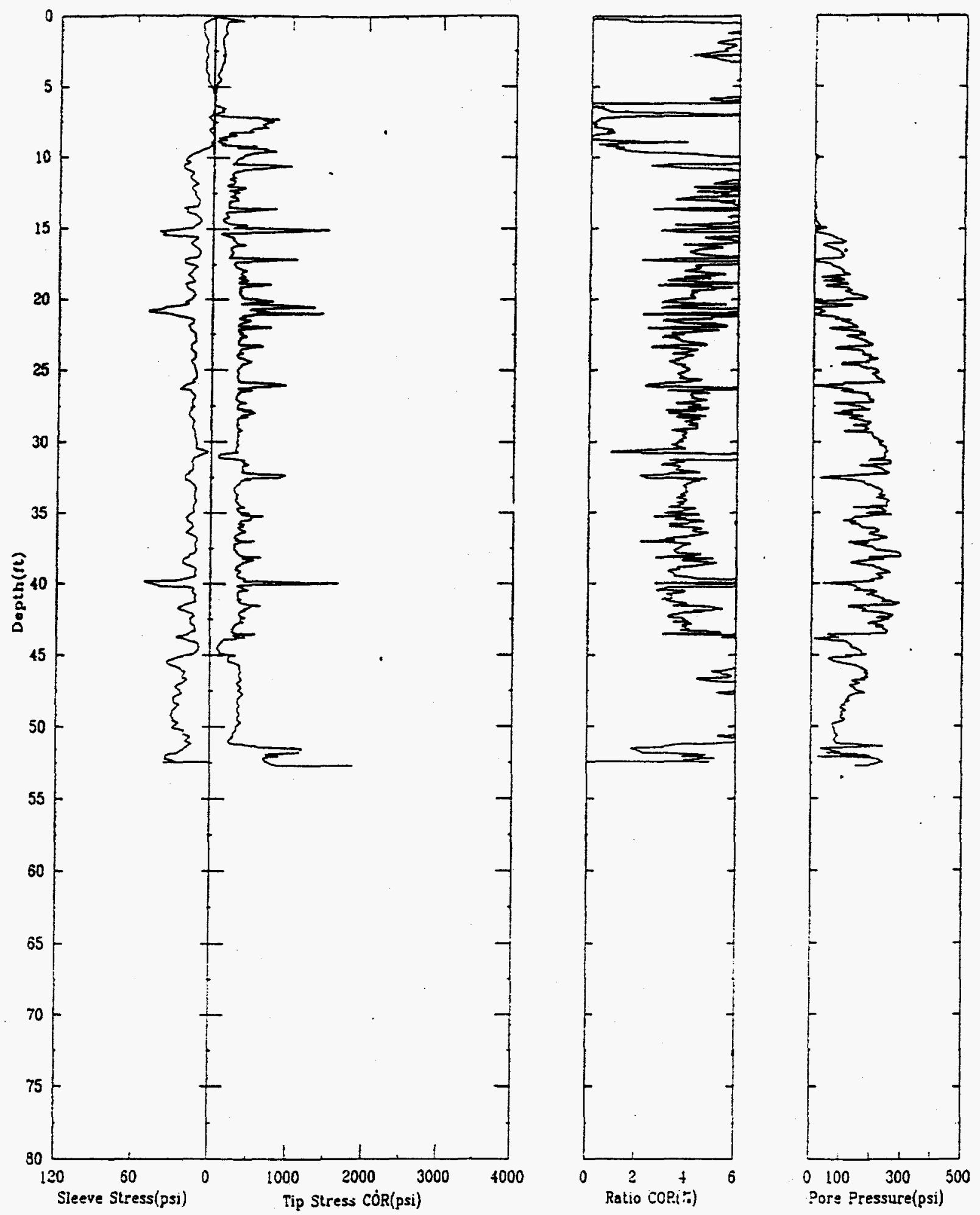

Figure C.3a. 


North 760 East 900 Elevation

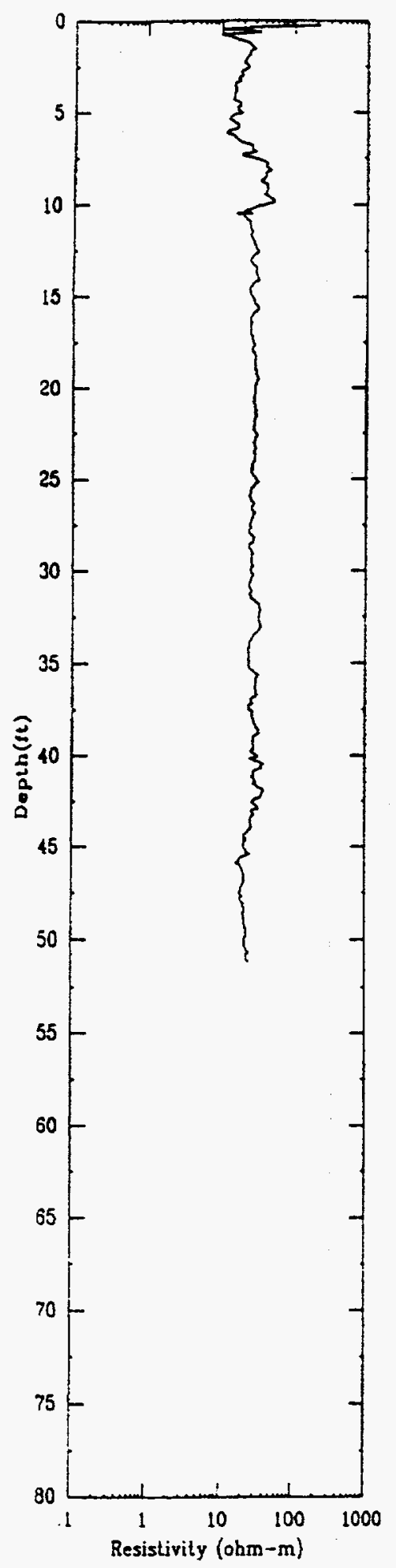

Figure C.3b. 
CPT -04

APPLIED RESEARCH ASSOCIATES, NNC.

$09 / 20 / 95$

Vorth $790^{\circ}$ East 941 Elevation
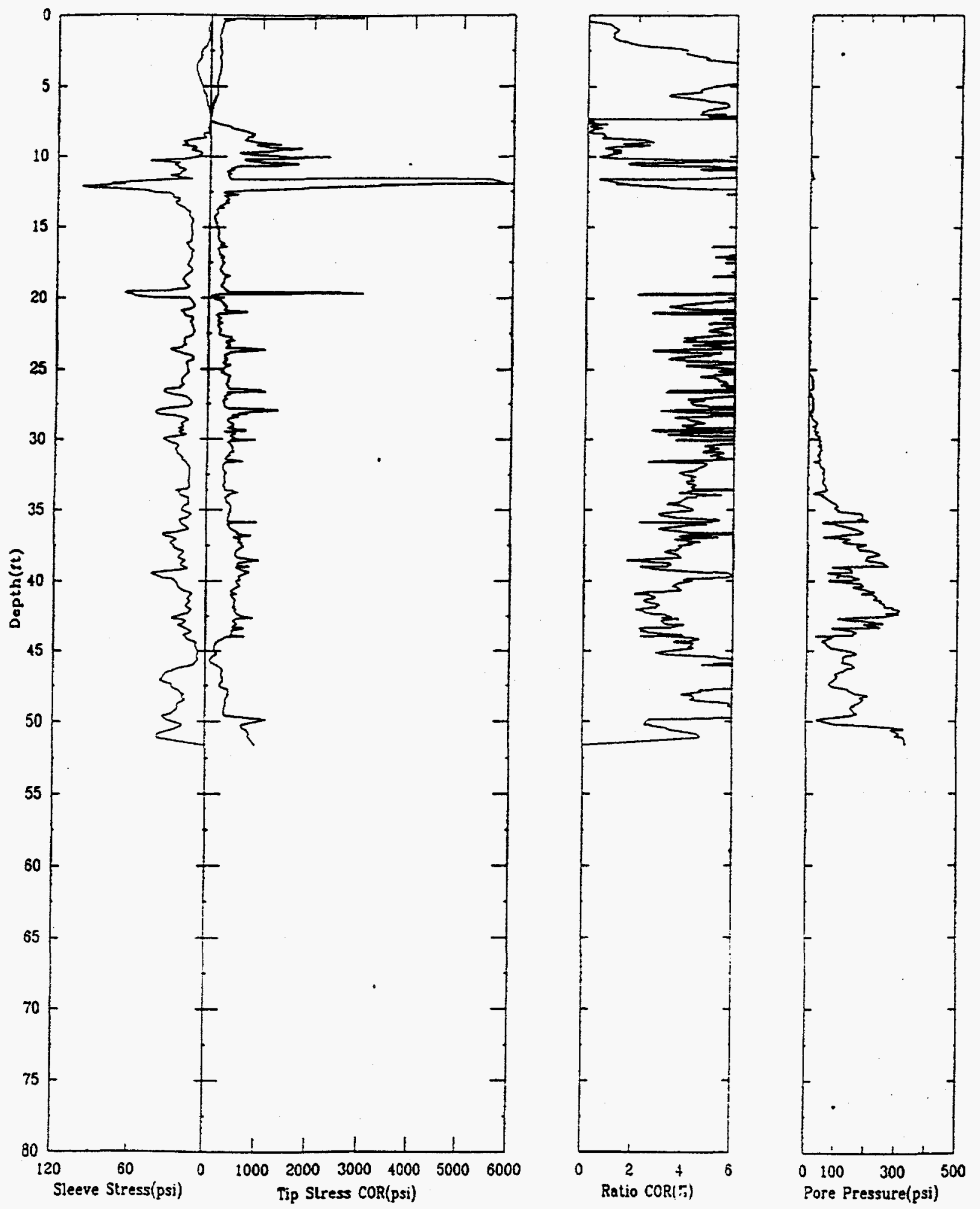

Figure C.4a. 
$\mathrm{CPT}-04$

APPLIED RESEARCH ASSOCIATES, INC.

$09 / 20 / 95$

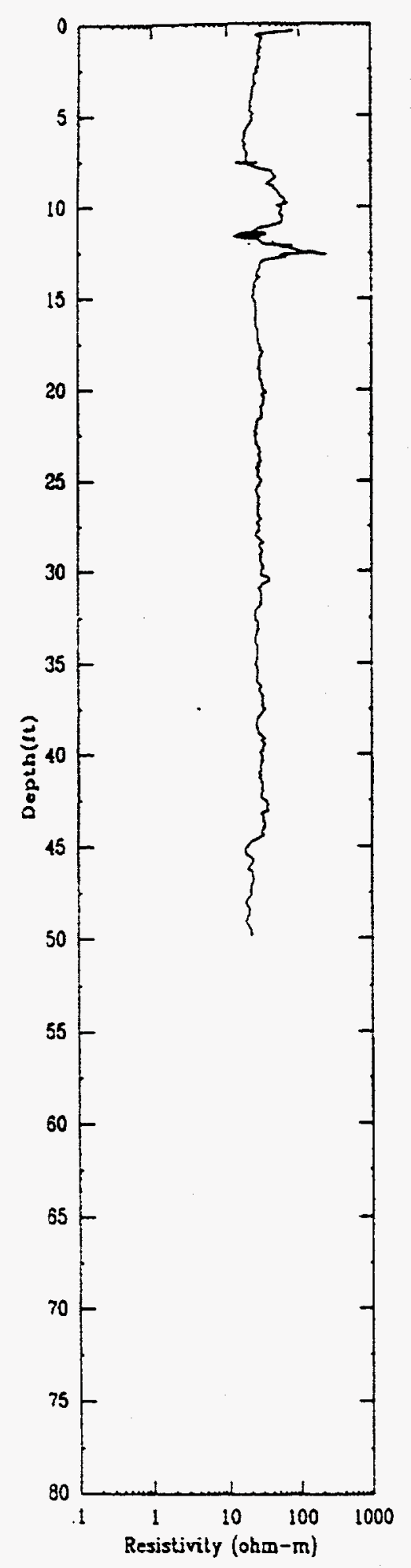

Figure C.4b. 
CPT $-05 \mathrm{C}$

APPLIED RESEARCH ASSOCIATES, INC.

$09 / 21 / 95$

North $902 \quad$ East $947 \quad$ Elevation
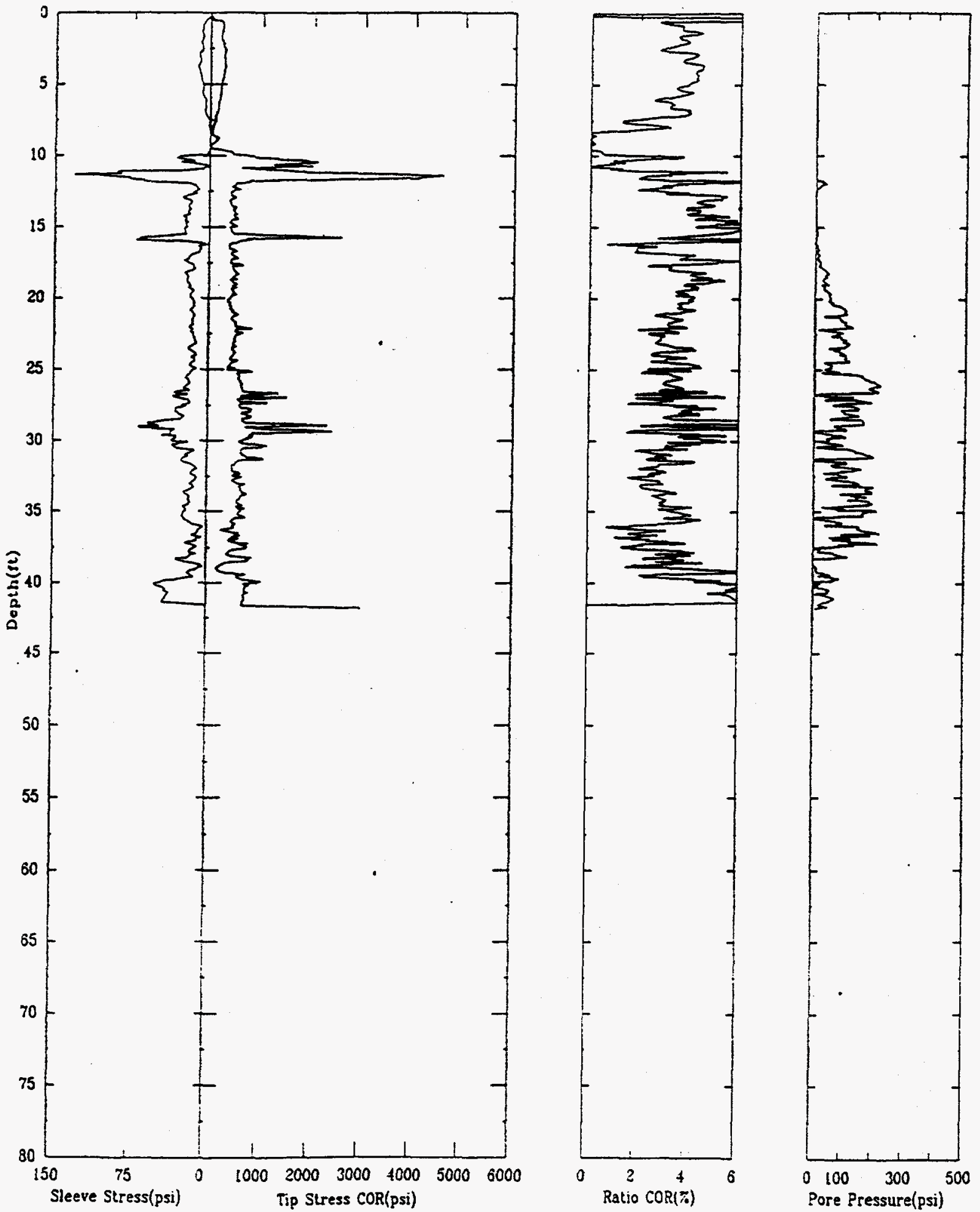

Figure C.5a. 


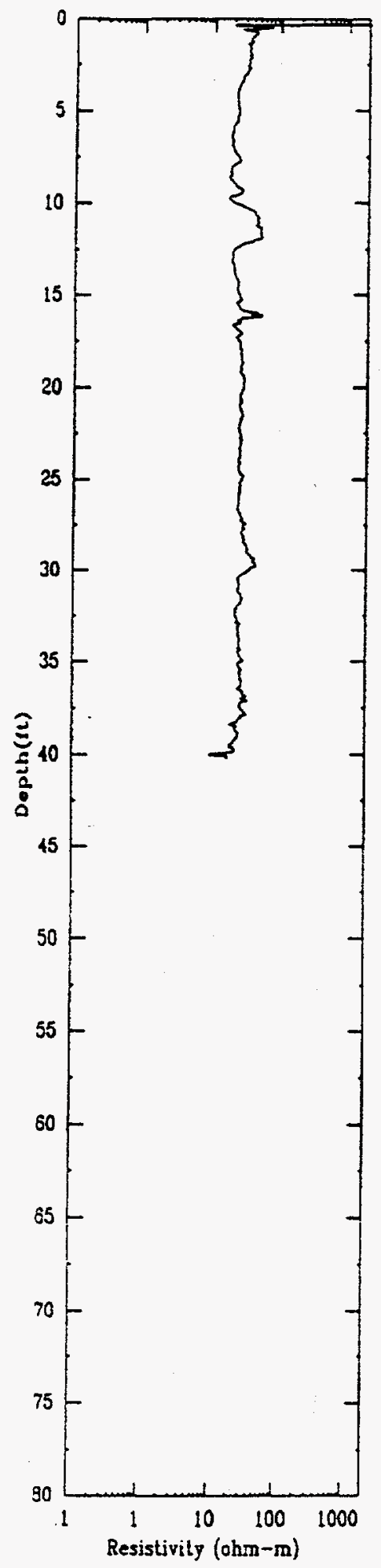

Figure C.5b. 
CPT-6

APPLIED RESEARCH ASSOCIATES, INC.

$09 / 21 / 95$ North $980 . \quad$ East 932 Elevation
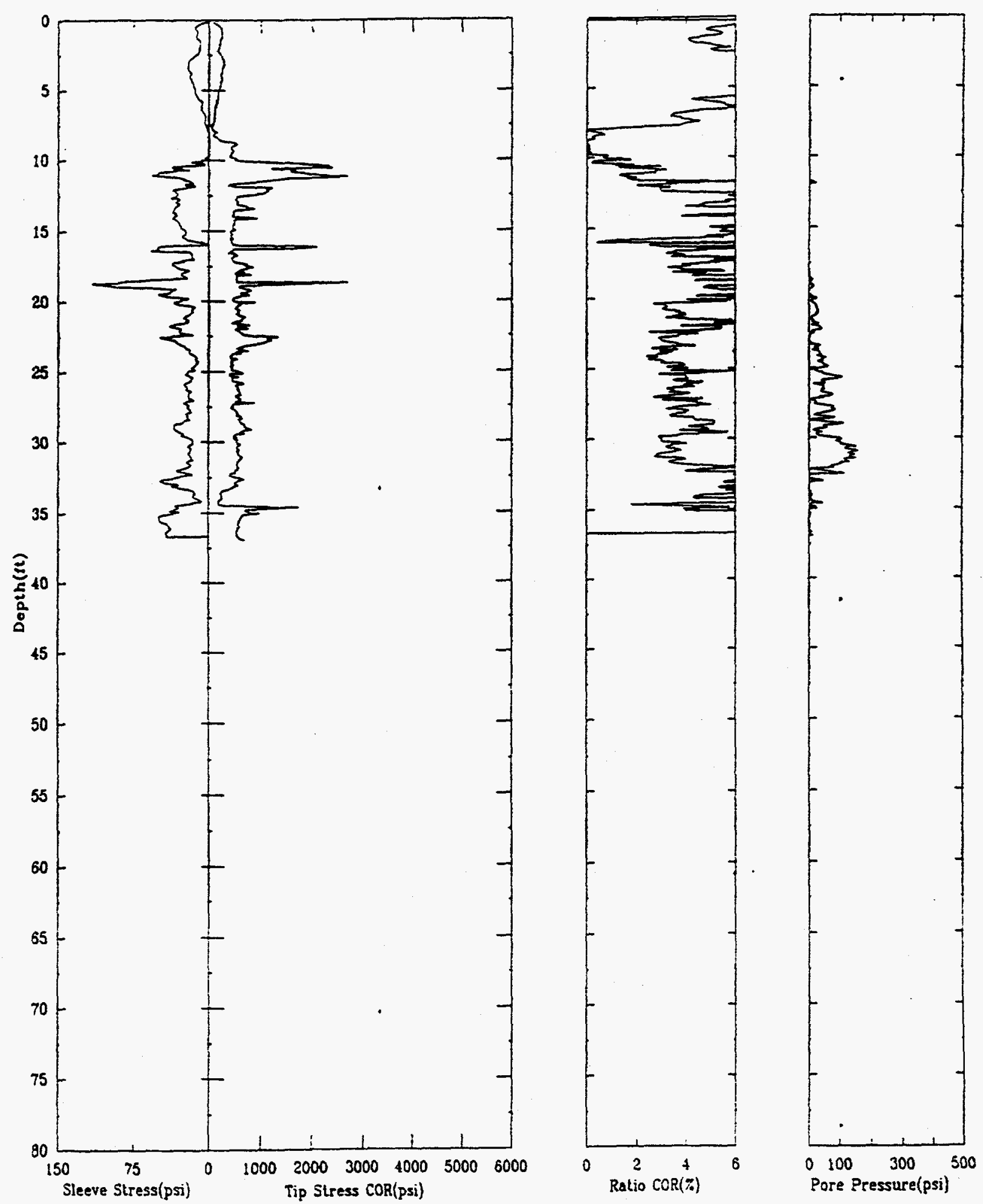

Figure C.6a. 
CPT -6

APPLIED RESEARCH ASSOCIATES, INC.

$09 / 21 / 95$ North 980 East $932 \quad$ Elevation

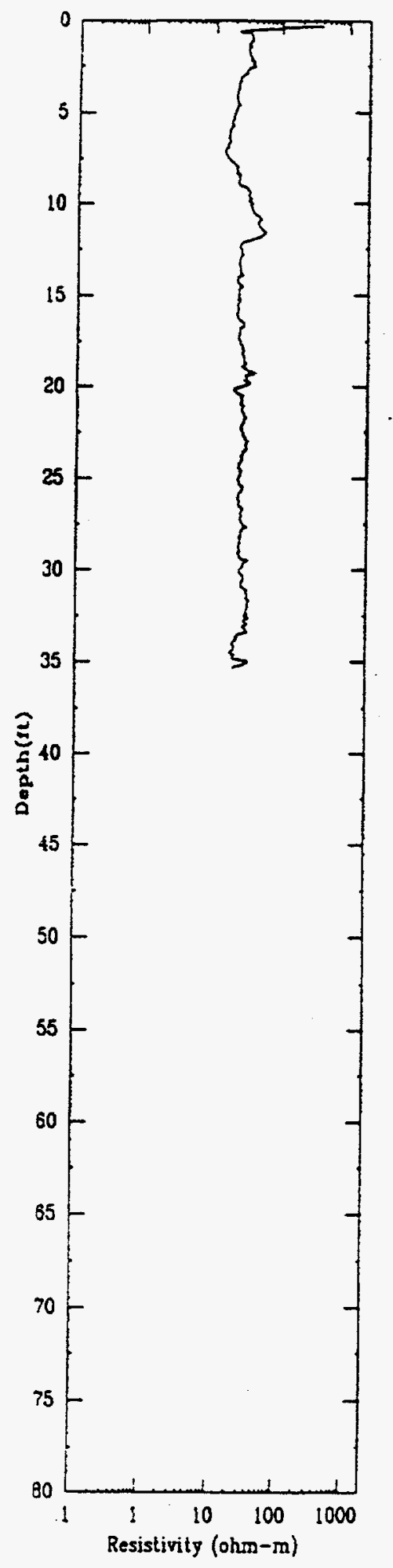

Figure C.6b. 
CPT -7

APPLIED RESEARCH ASSOCIATES, INC.

09/21/95

North $1000 \quad$ East $927 \quad$ Elevation
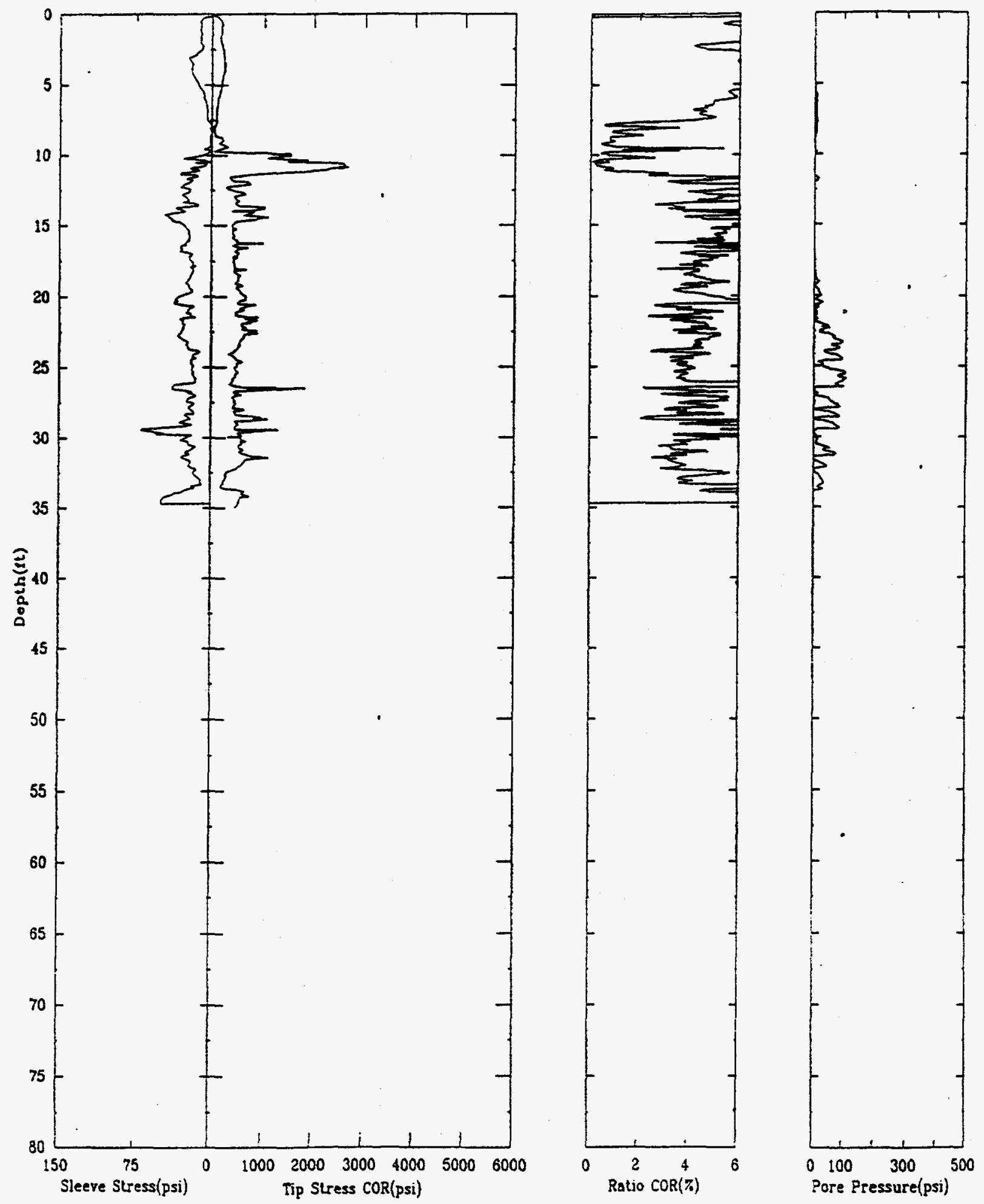

Figure C.7a. 
CPT-7 APPLIED RESEARCH ASSOCIATES, INC.

$09 / 21 / 95$ North $1000 \quad$ East $927 \quad$ Elevation

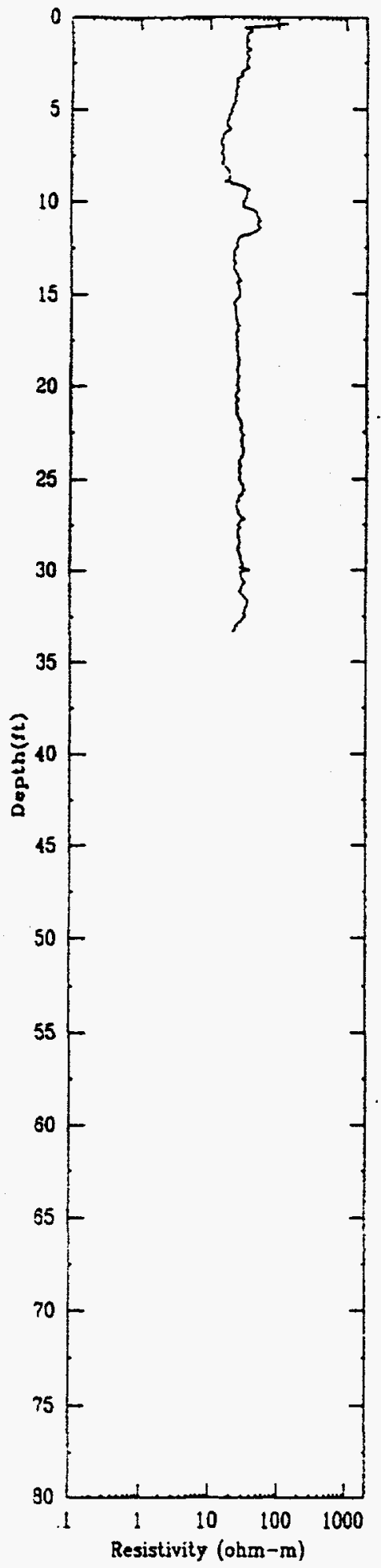

Figure C.7b. 
CPT-8

APPLIED RESEARCH ASSOCIATES, INC.

$09 / 21 / 95$

Viorth 1240 East $870 \quad$ Elevation
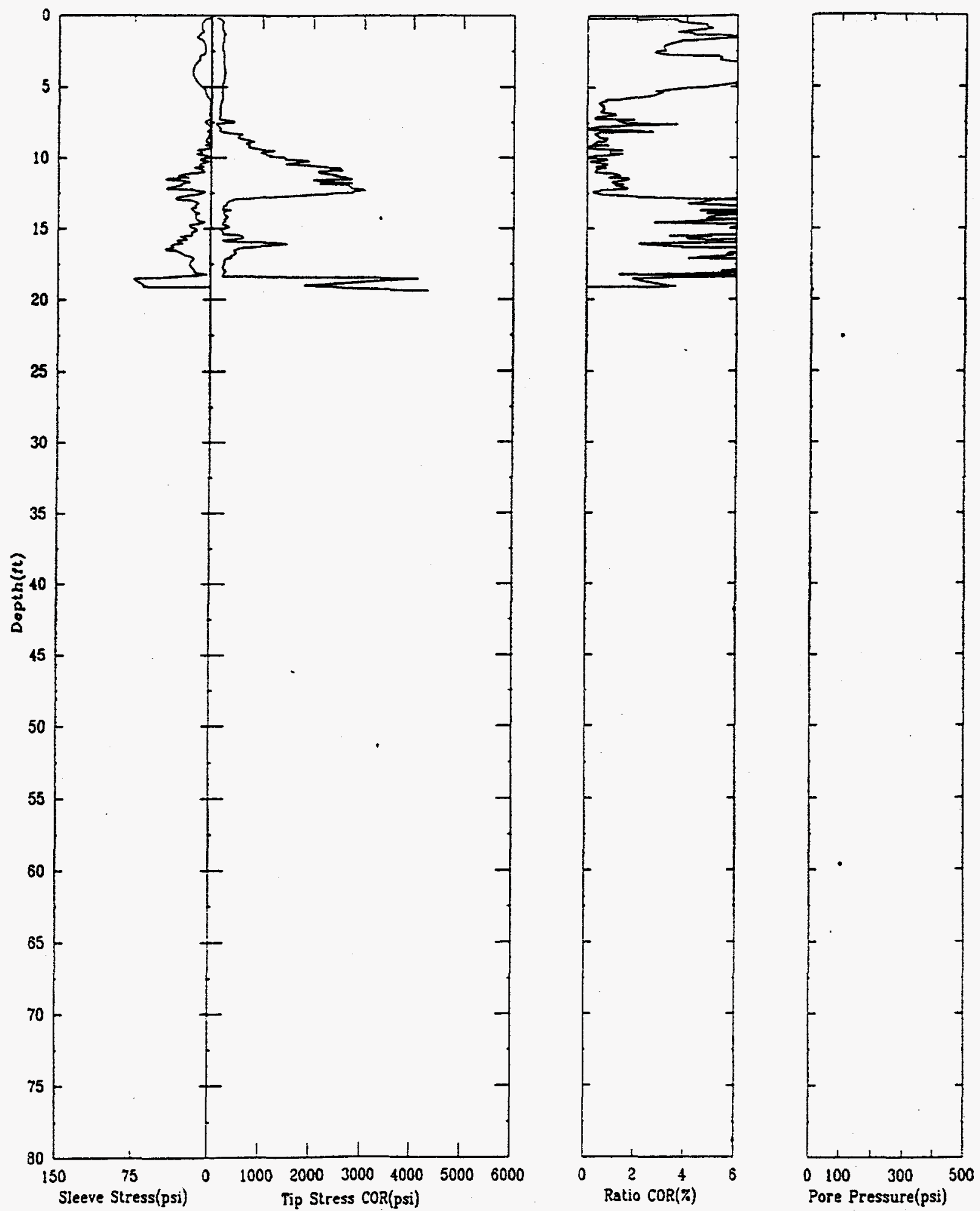

Figure C.8a. 
CPT-8

APPLIED RESEARCH ASSOCIATES, INC.

$09 / 21 / 95$

North 1240

East 870

Elevation

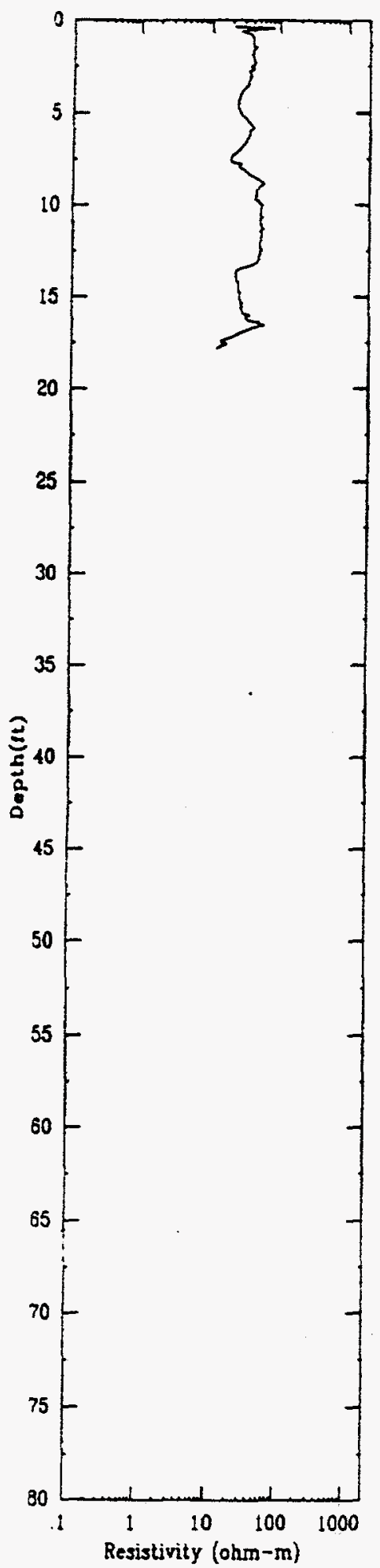

Figure C.8b. 
CPT -9

APPLIED RESEARCH ASSOCIATES, INC.

$09 / 21 / 95$ Vorth $700 \quad$ East $891 \quad$ Elevation
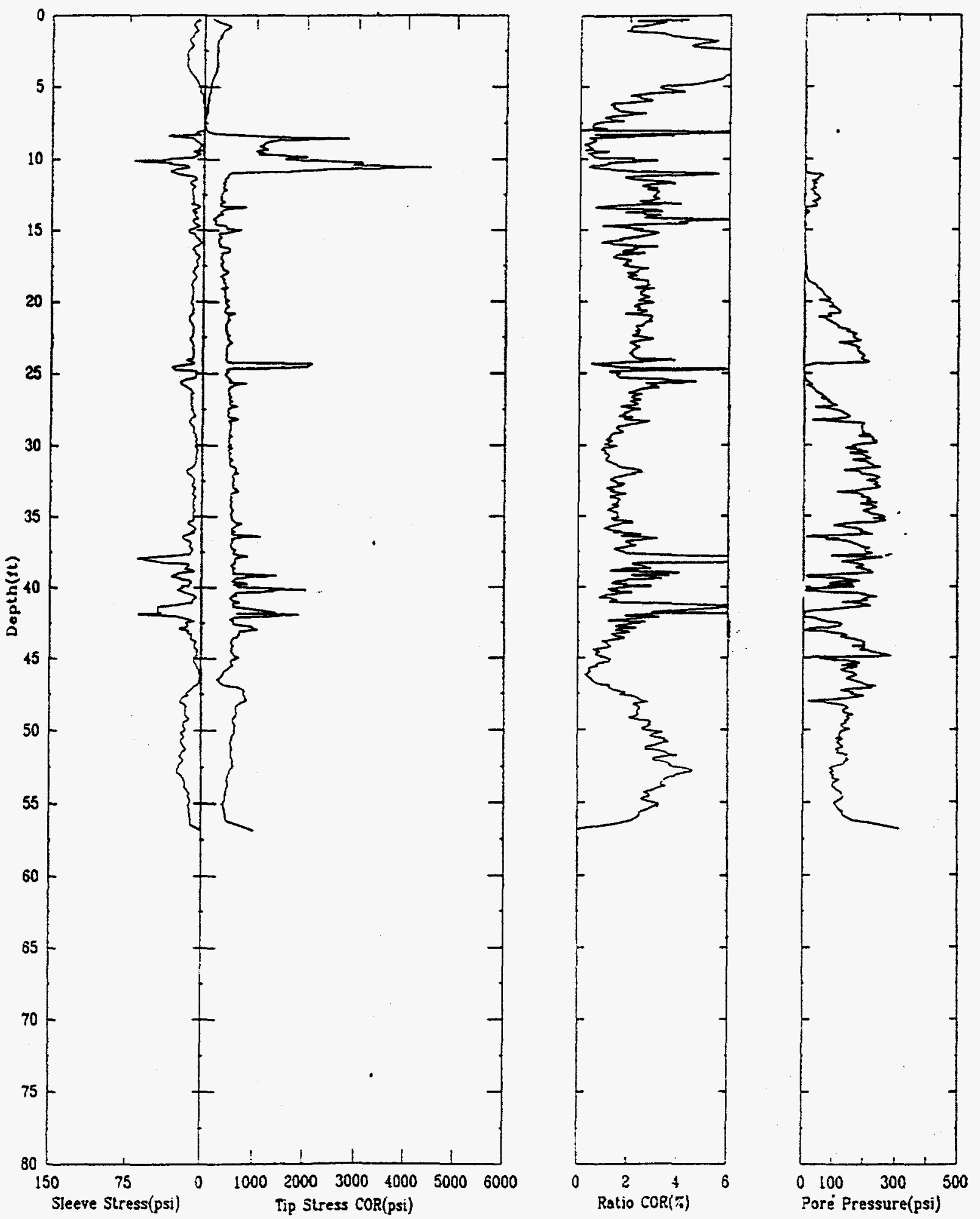

Figure C.9a. 
CPT -9

APPLIED RESEARCH ASSOCIATES, INC.

North 700

East 891

Elevation

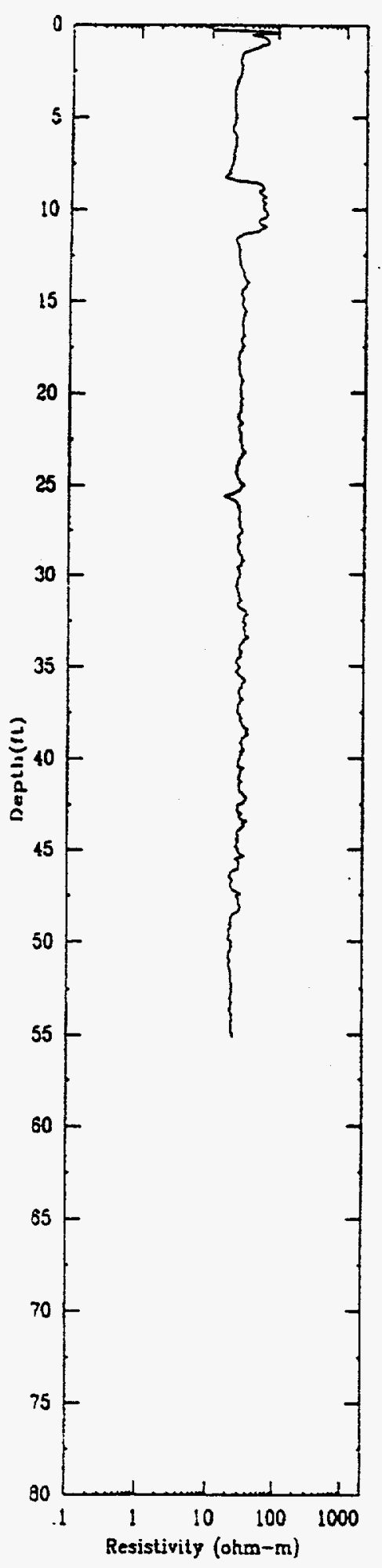

Figure C.9b. 
CPT -10

APPLIED RESEARCH ASSOCIATES. INC.

$09 / 21 / 95$

Yorth 451 East 850 Elevation
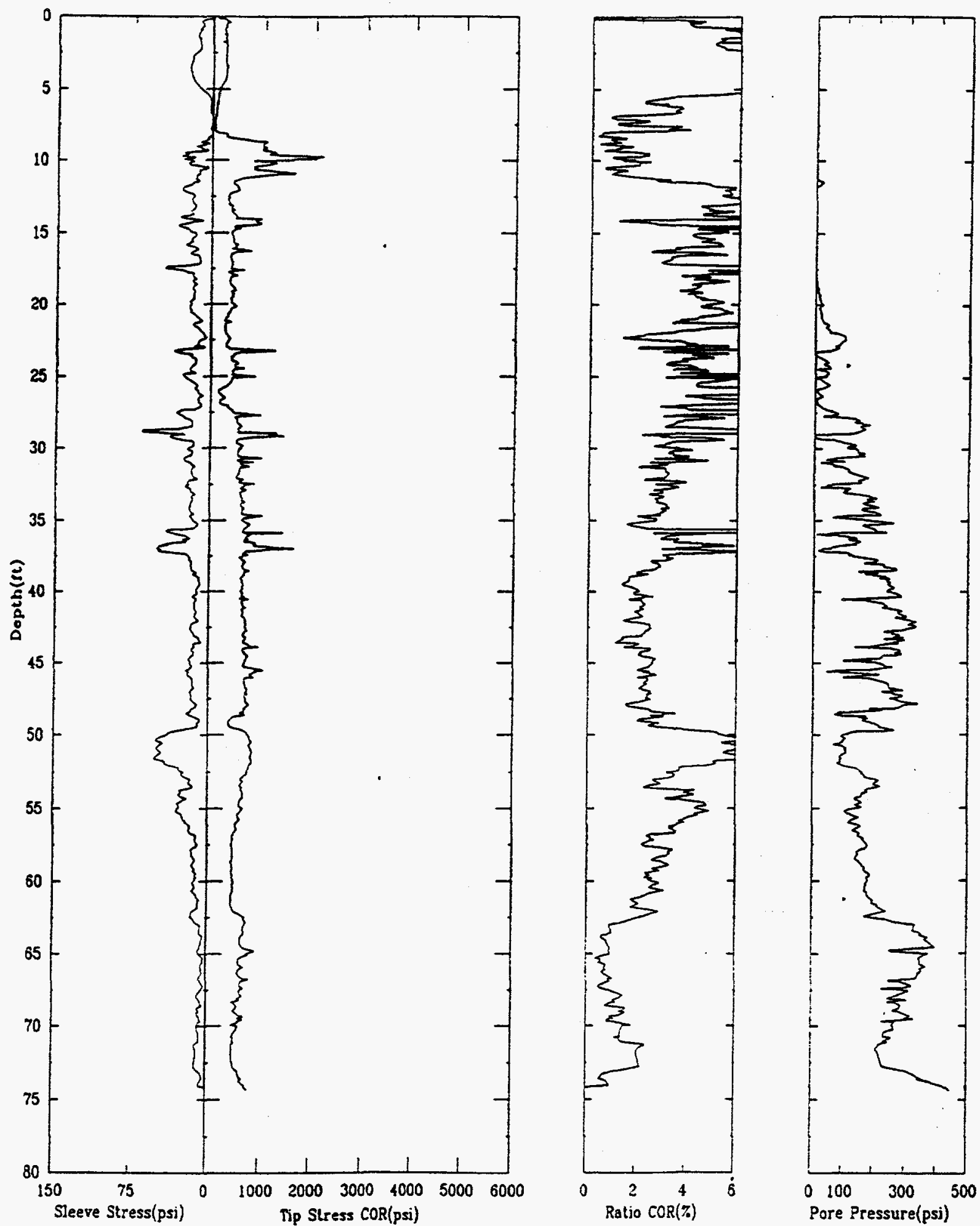

Figure C.10a. 


North 451 East 850 Elevation

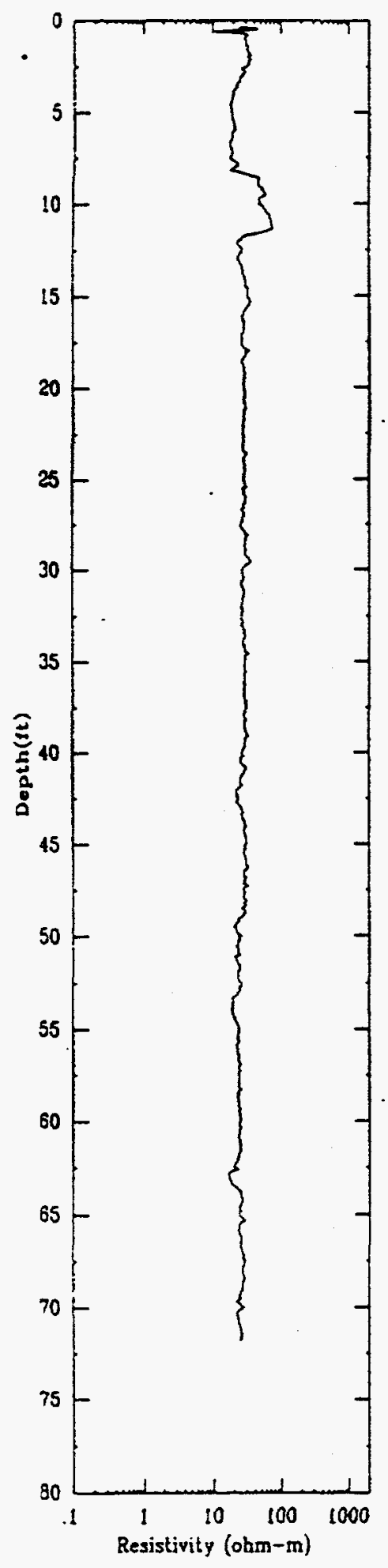

Figure C.10b. 
CPT -11

APPLIED RESEARCH ASSOCIATES. INC.

$09 / 22 / 95$

Yorth 497 East $860 \quad$ Elevation
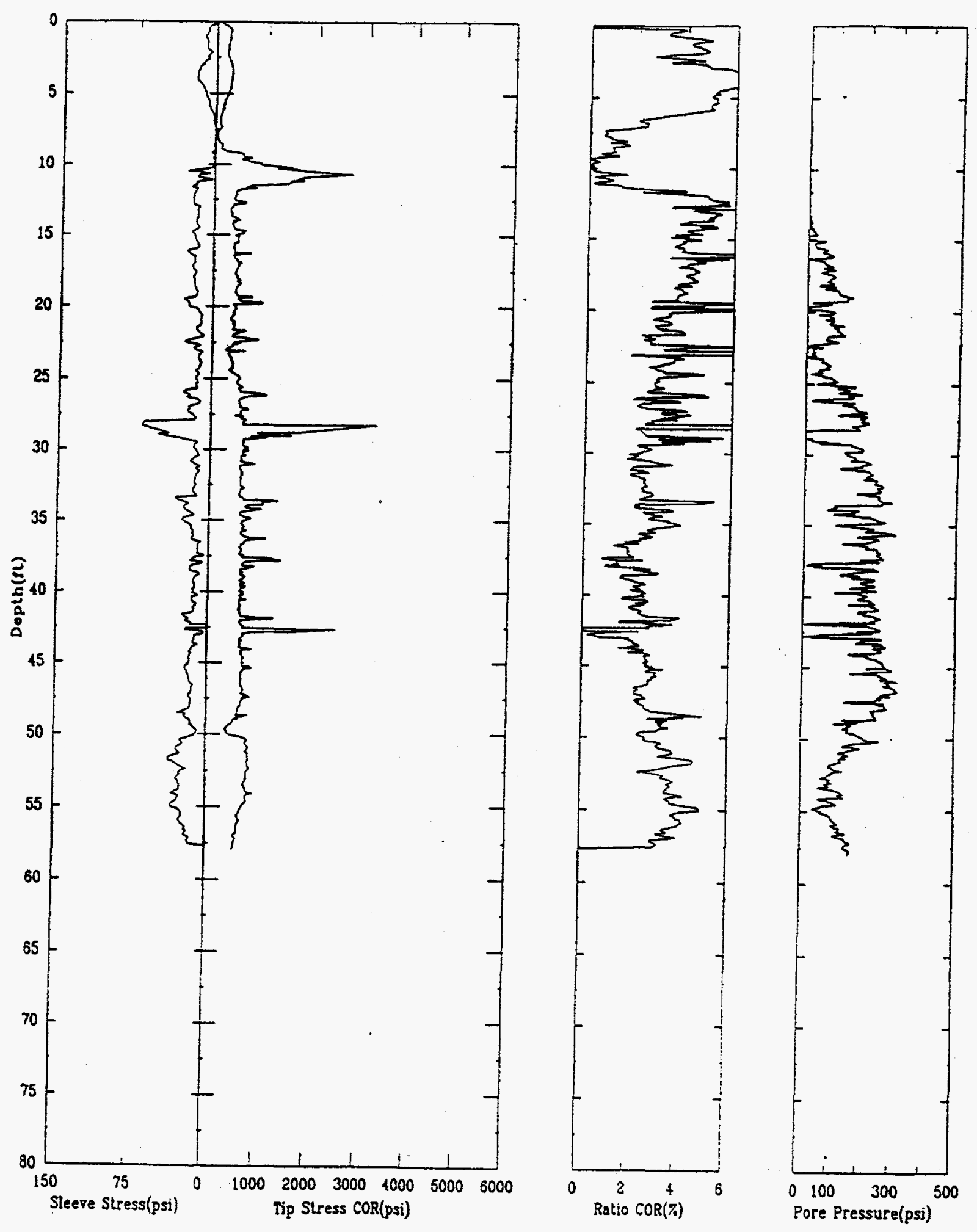

Figure C.11a. 


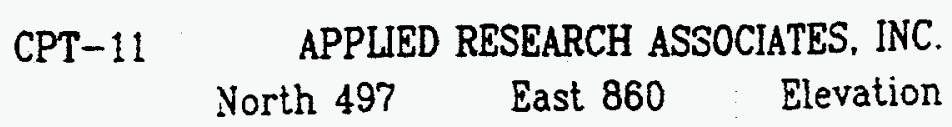

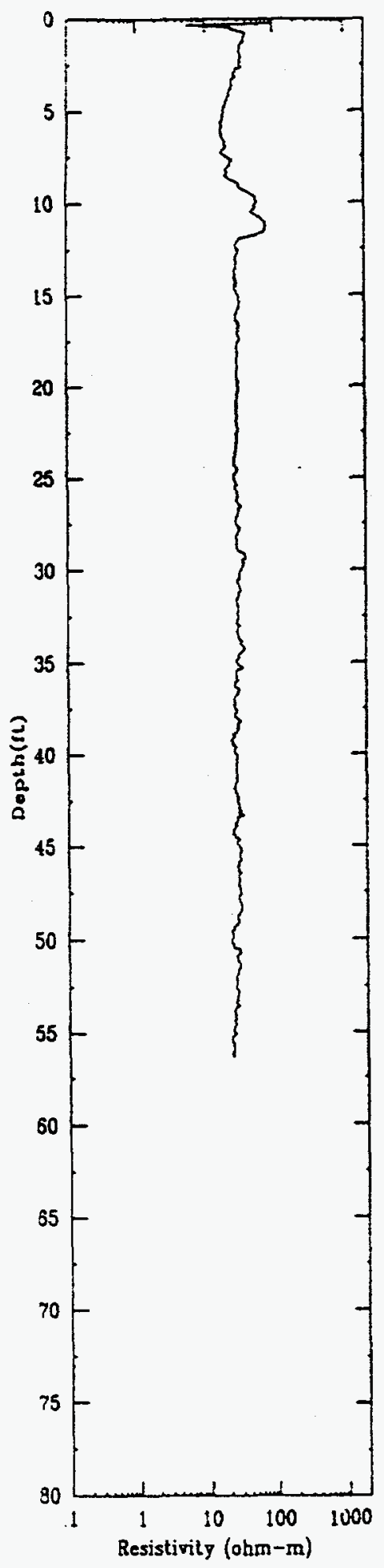

Figure C.11b. 
CPT -12

APPLIED RESEARCH ASSOCIATES, INC.

$09 / 22 / 95$

North $705 \quad$ East $843 \quad$ Elevation
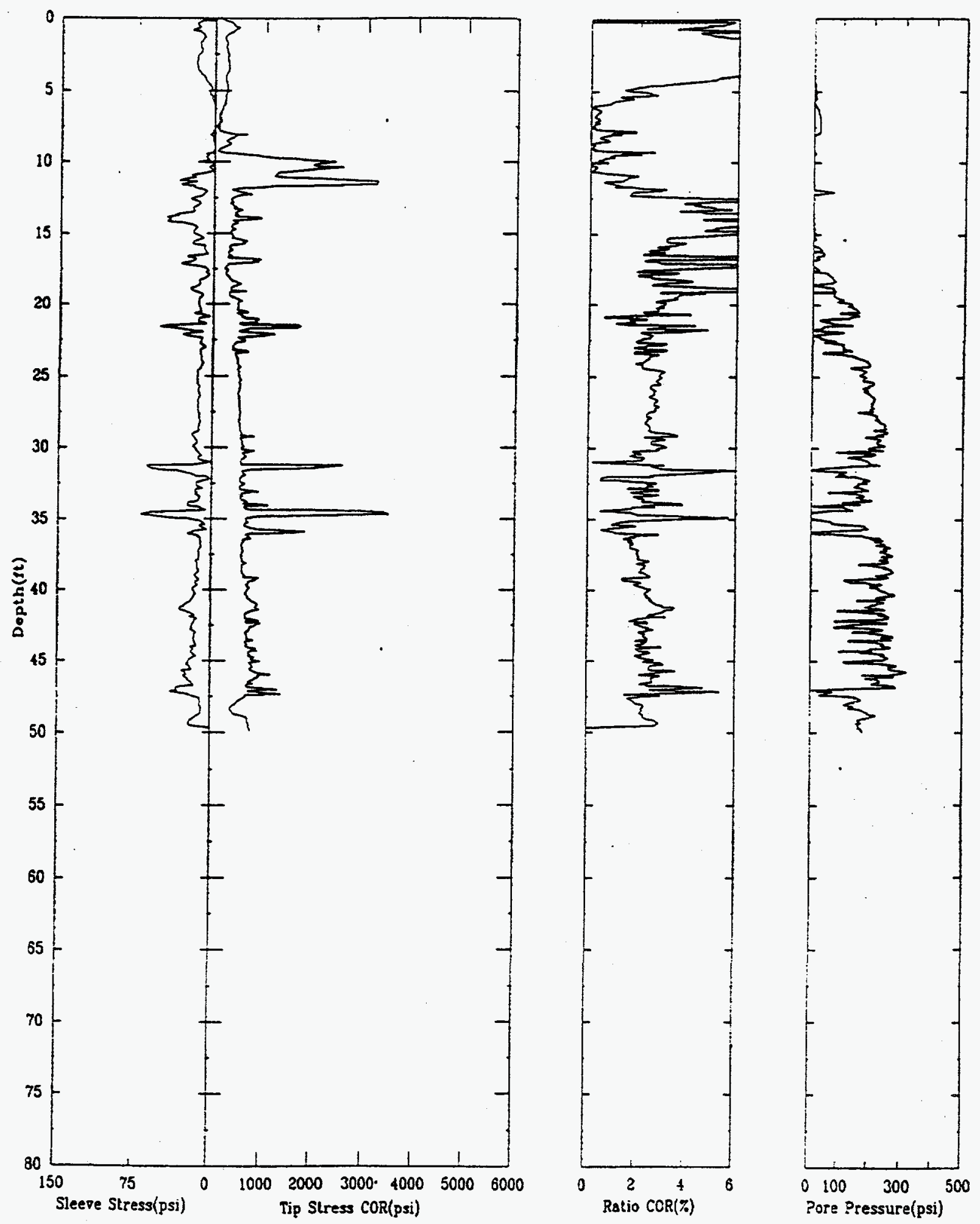

Figure C.12a. 
CPT -12

APPLEDD RESEARCH ASSOCIATES, INC.

$09 / 22 / 95$ North 705 East $843 \quad$ Elevation

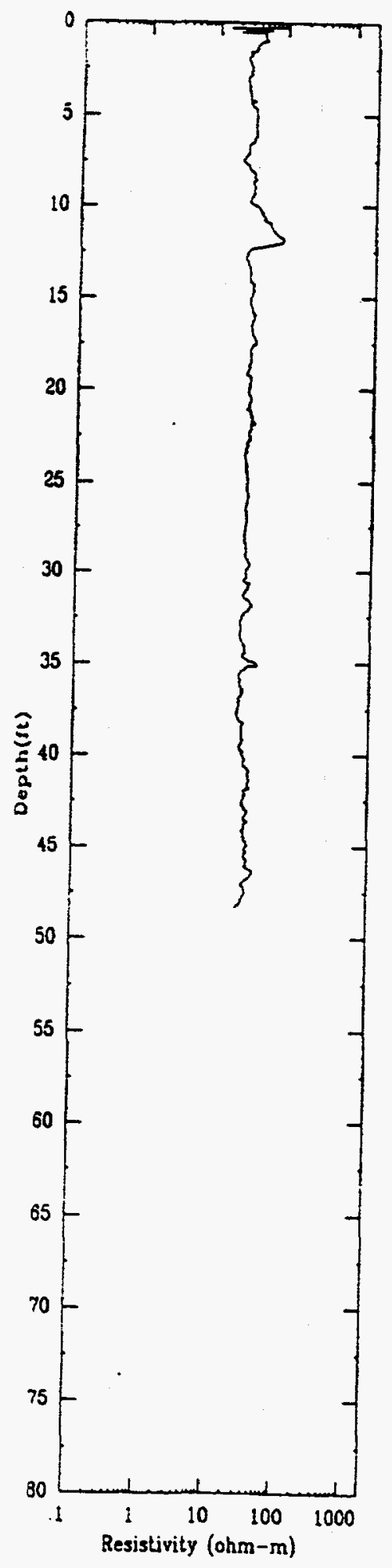

Figure C.12b. 
CPT -13

APPLIED RESEARCH ASSOCIATES, INC.

$09 / 22 / 95$

North 817 East $844 \quad$ Elevation
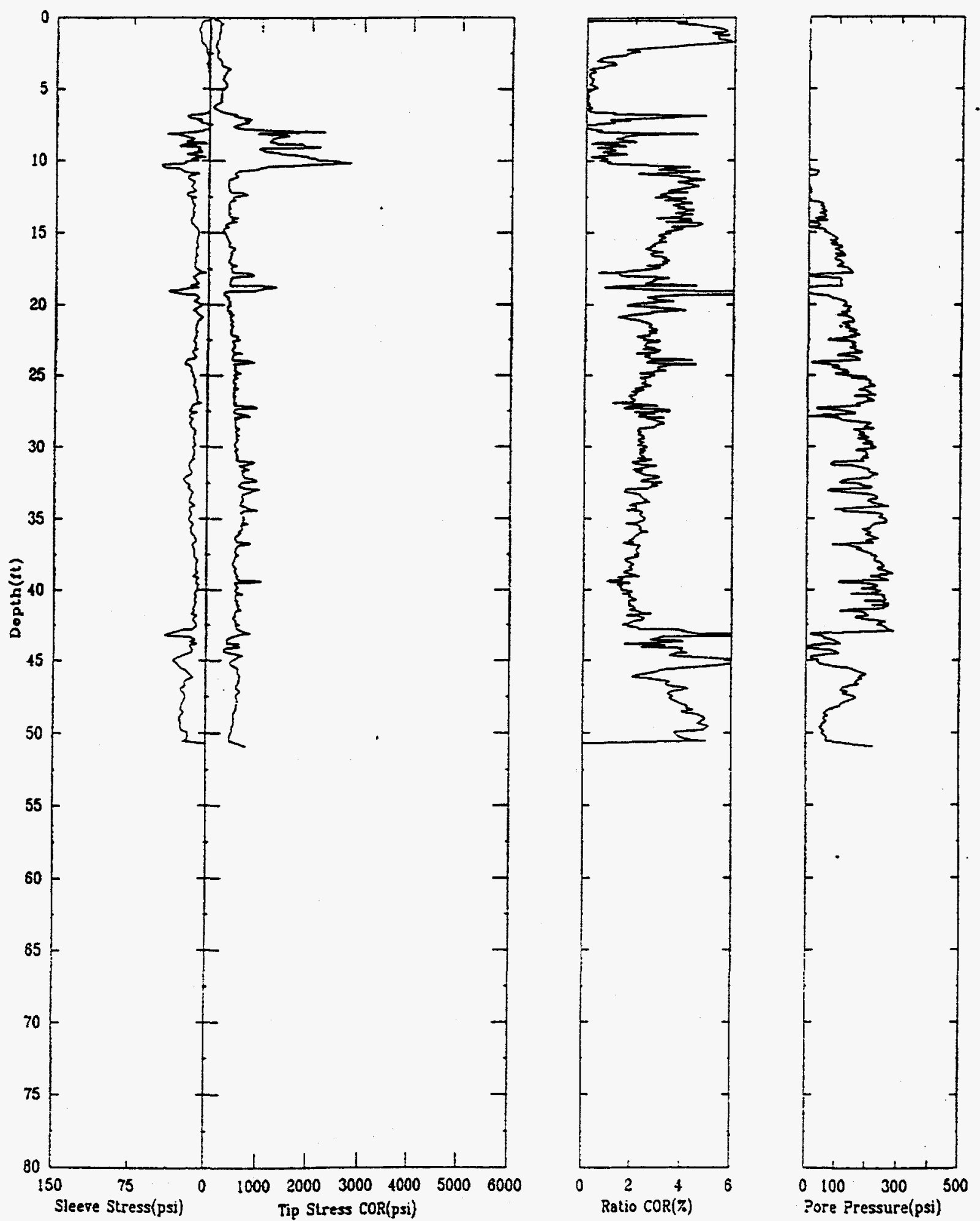

Figure C.13a. 
CPT -13

APPLIED RESEARCH ASSOCIATES, INC.

$09 / 22 / 95$

North $817 \quad$ East $844 \quad$ Elevation

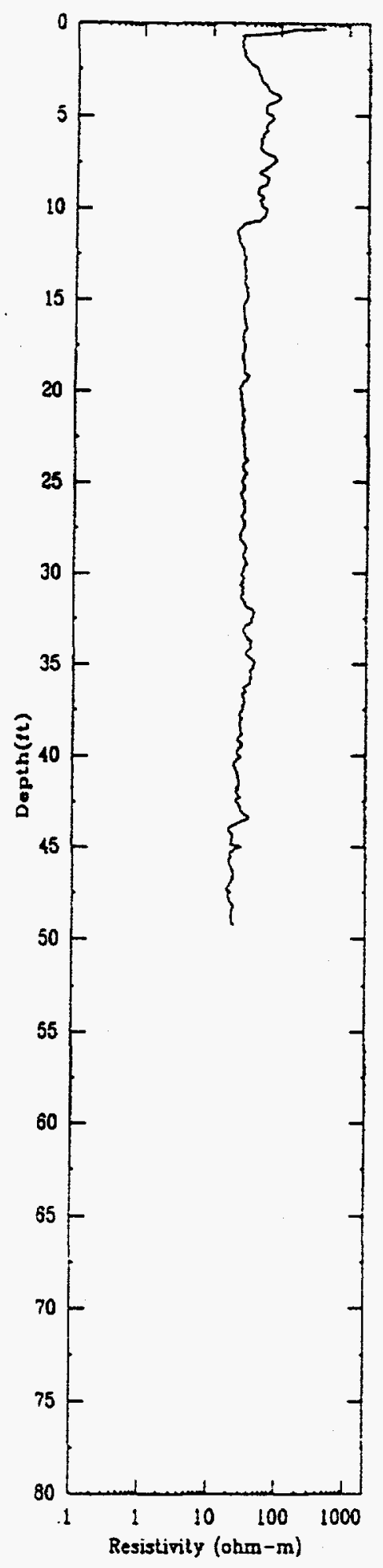

Figure C.13b. 
CPT -14

APPLIED RESEARCH ASSOCIATES, INC.

$09 / 22 / 95$

North 950 . East $846 \quad$ Elevation
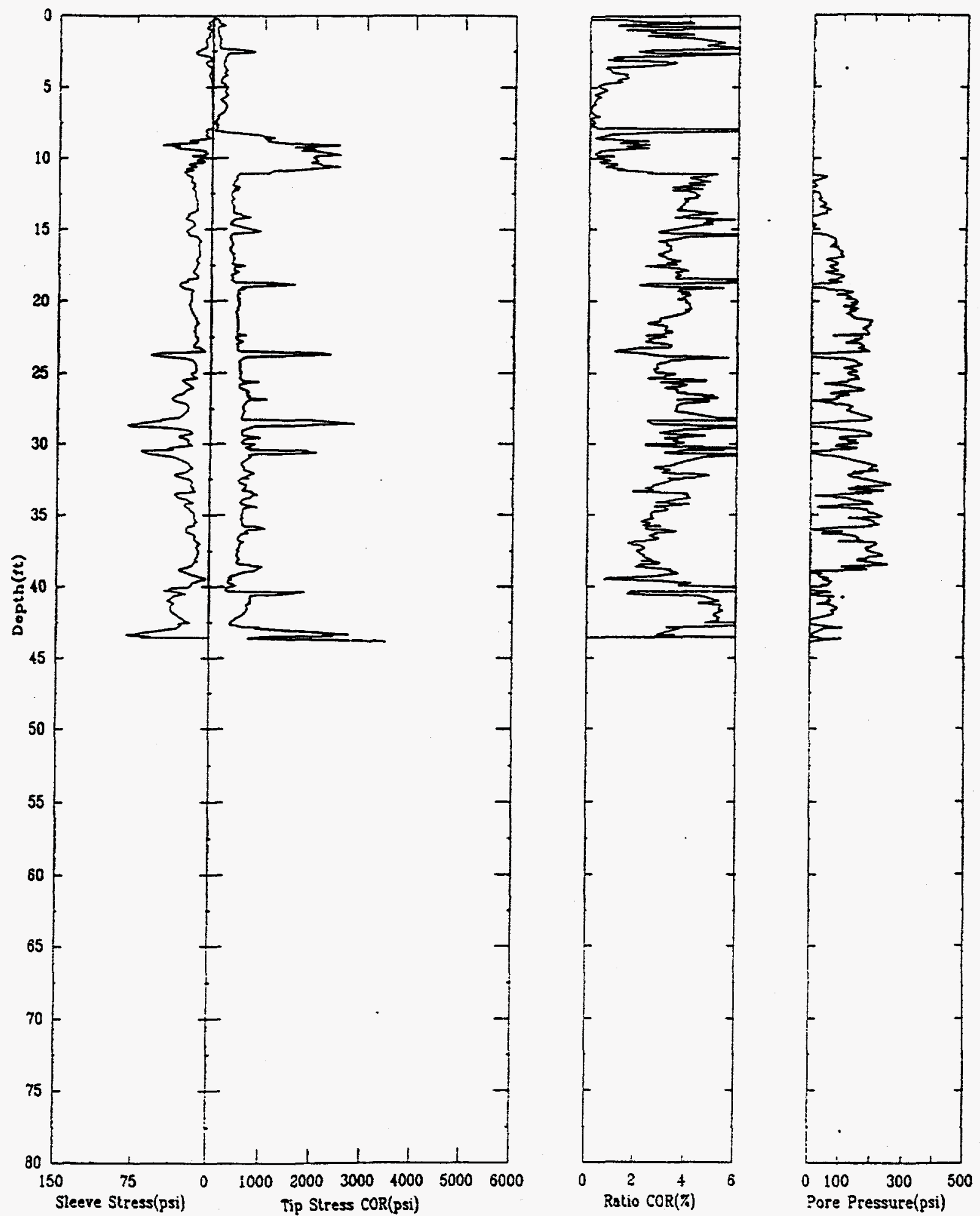

Figure C.14a. 
CPT-14

APPLIED RESEARCH ASSOCIATES. INC.

$09 / 22 / 95$ North $950 \quad$ East $846 \quad$ Elevation

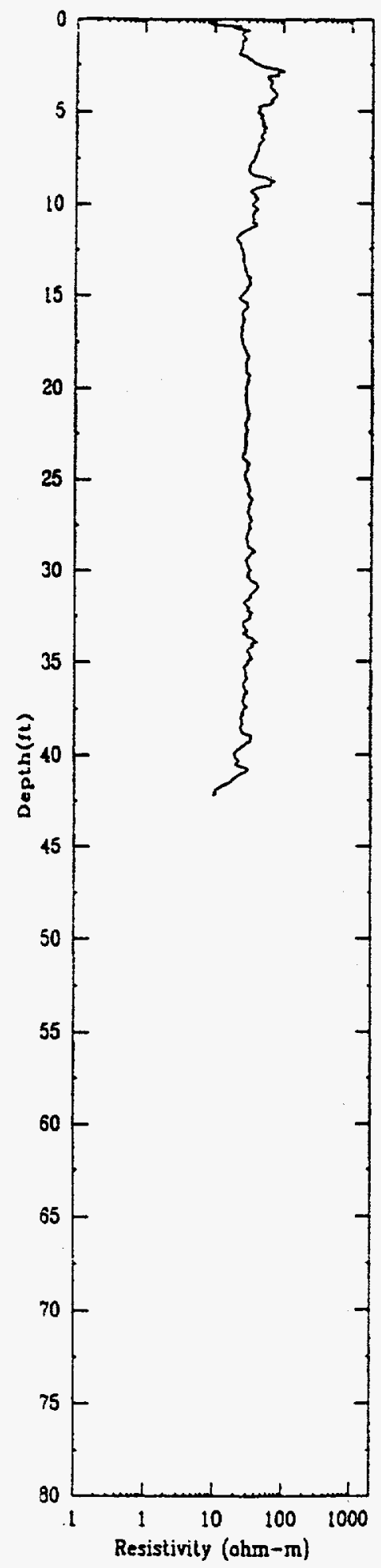

Figure C.14b. 
CPT -15

APPLIED RESEARCH ASSOCIATES, INC. North $985^{\circ}$ East $760 \quad$ Elevation
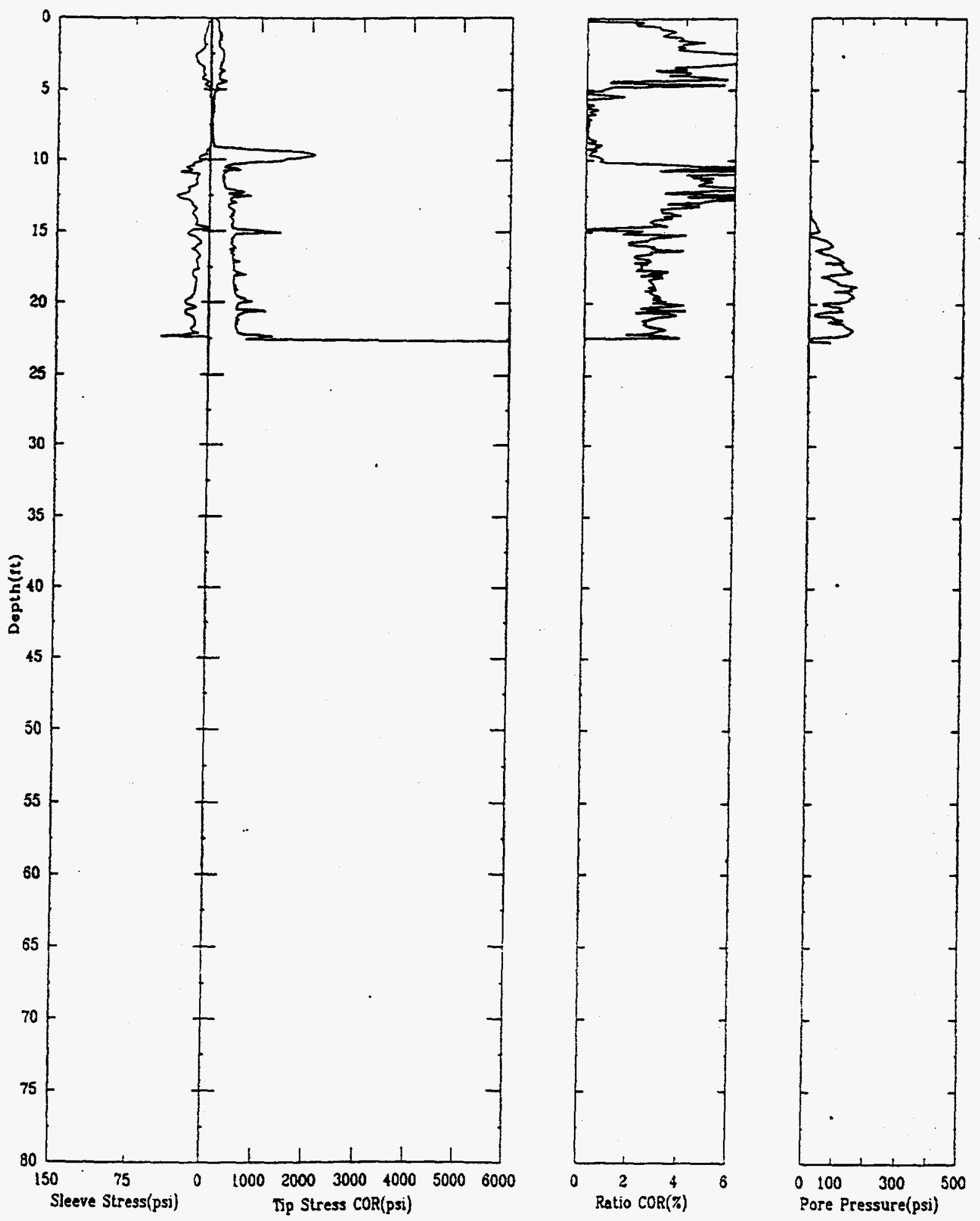

Figure C.15a. 
CPT -15

APPLED RESEARCH ASSOCIATES. INC.

$09 / 22 / 95$ North 985 East $760 \quad$ Elevation

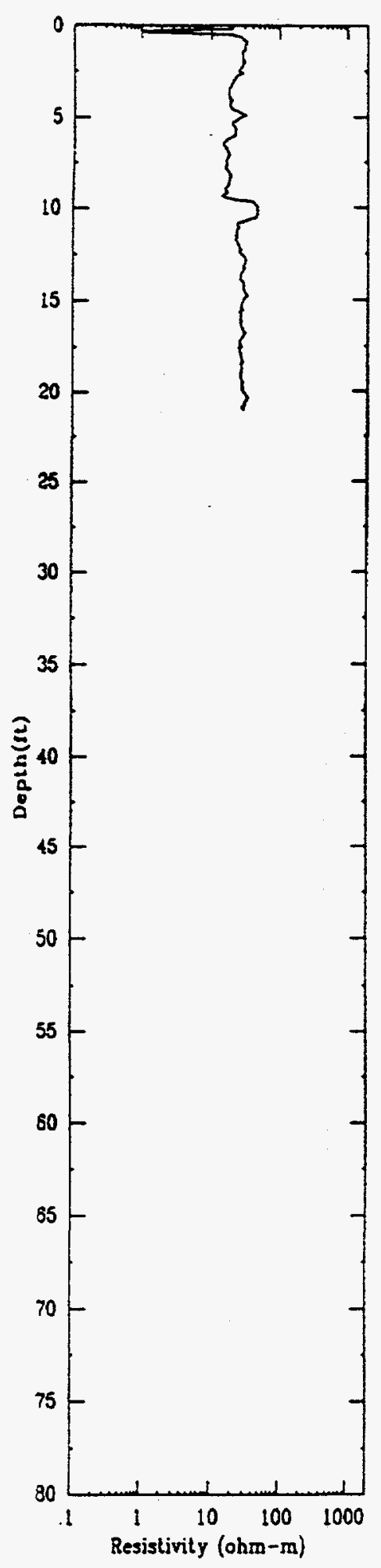

Figure C.15b. 


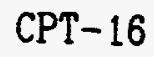

APPLIED RESEARCH ASSOCIATES, INC. North 850 East 780 Elevation

09/2்/95
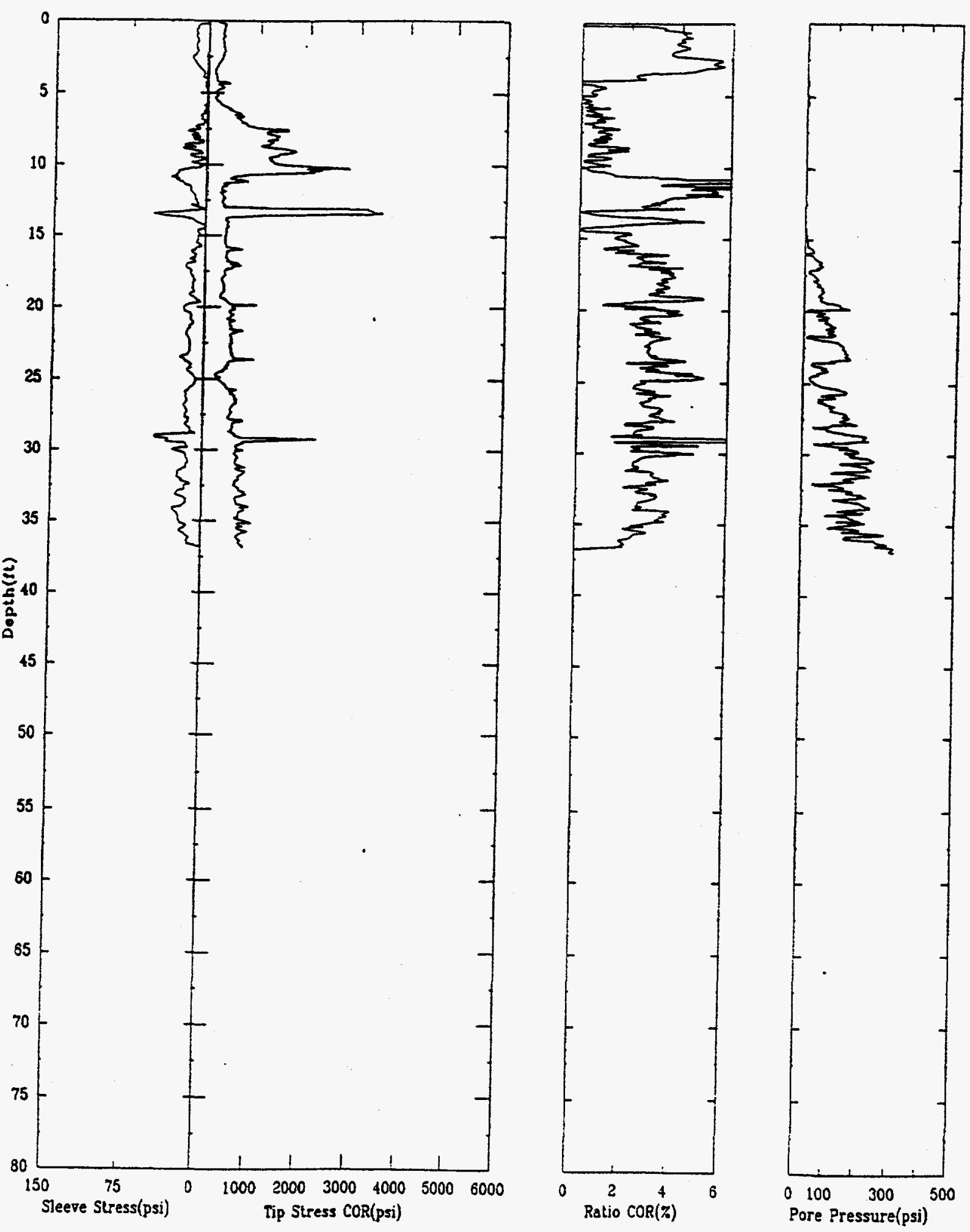

Figure C.16a. 
CPT -16

APPLIED RESRAARCH ASSOCIATES, INC.

$09 / 22 / 95$

North $850 \quad$ East $780 \quad$ Elevation

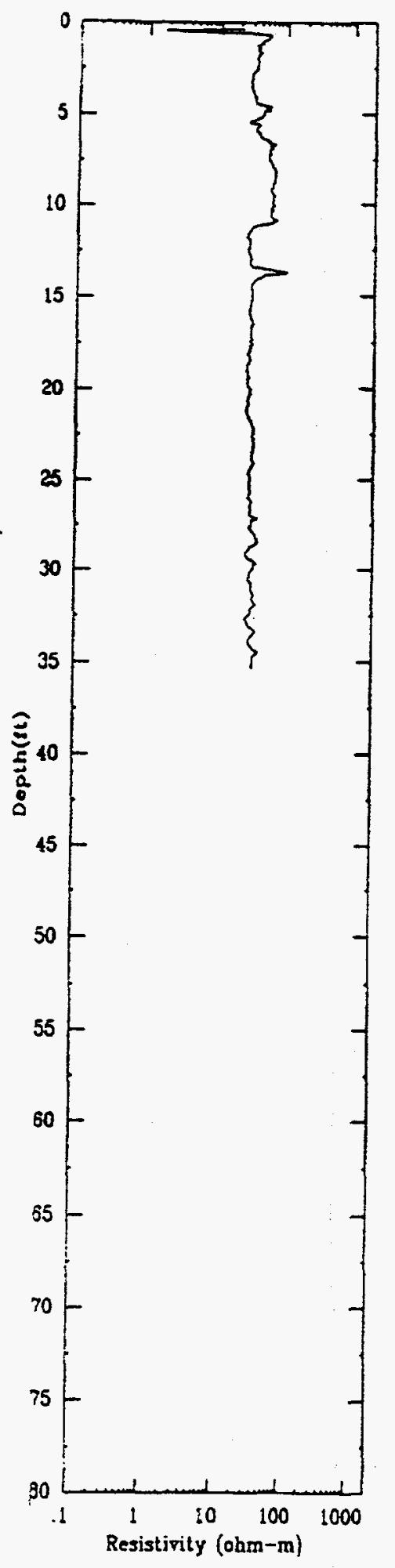

Figure C.16b. 
CPT-17

APPLIED RESEARCH ASSOCIATES, INC.

$09 / 22 / 95$

North 768 East $750 \quad$ Elevation
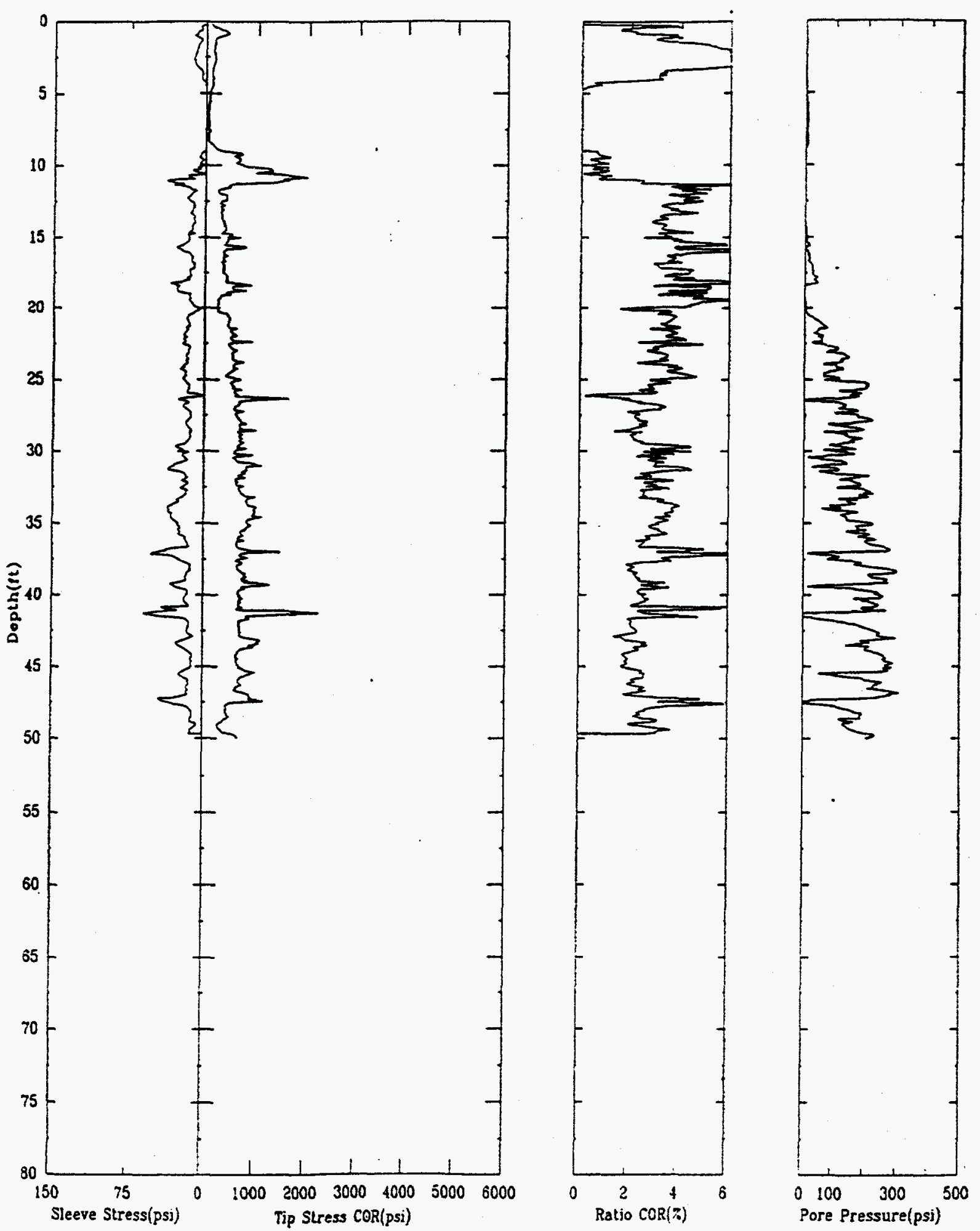

Figure C.17a. 
APPLIED RESEARCH ASSOCIATES, INC. North 768 East $750 \quad$ Elevation

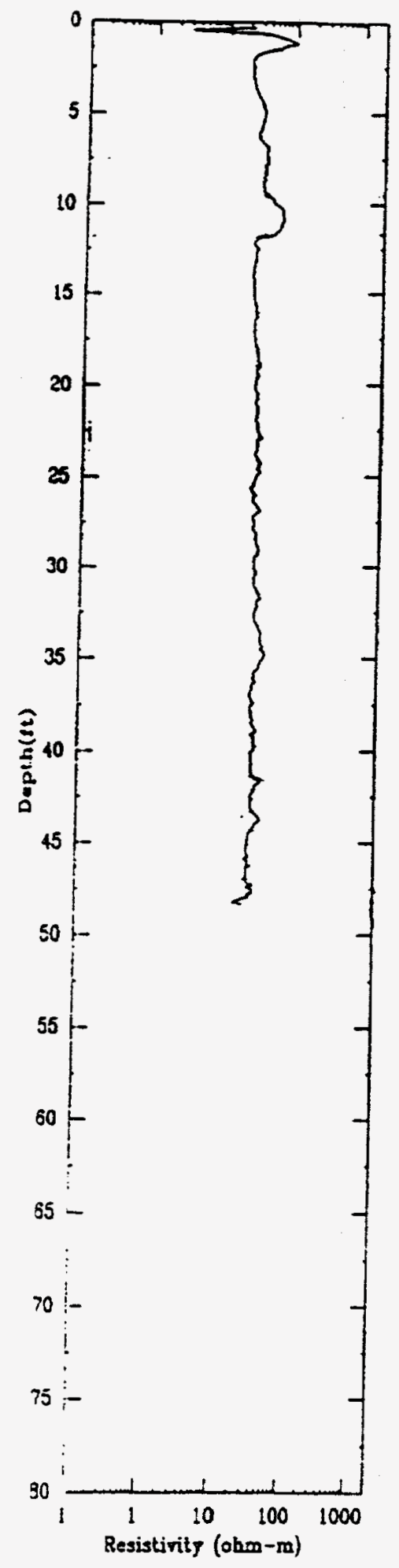

Figure C.17b. 
APPENDIX D:

EM-31 AND GPR DATA FROM AREA 1 


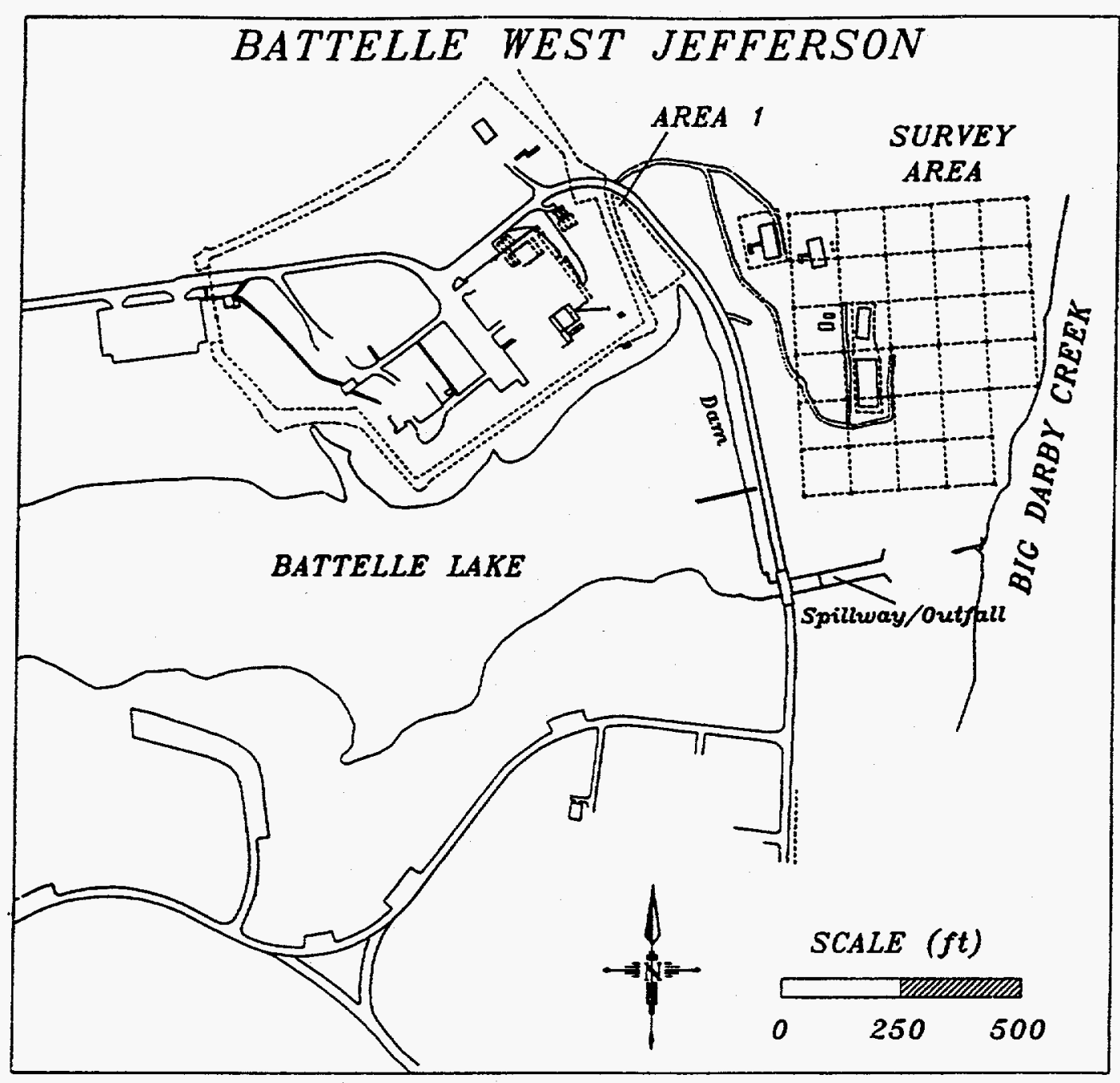

Figure D.1. 


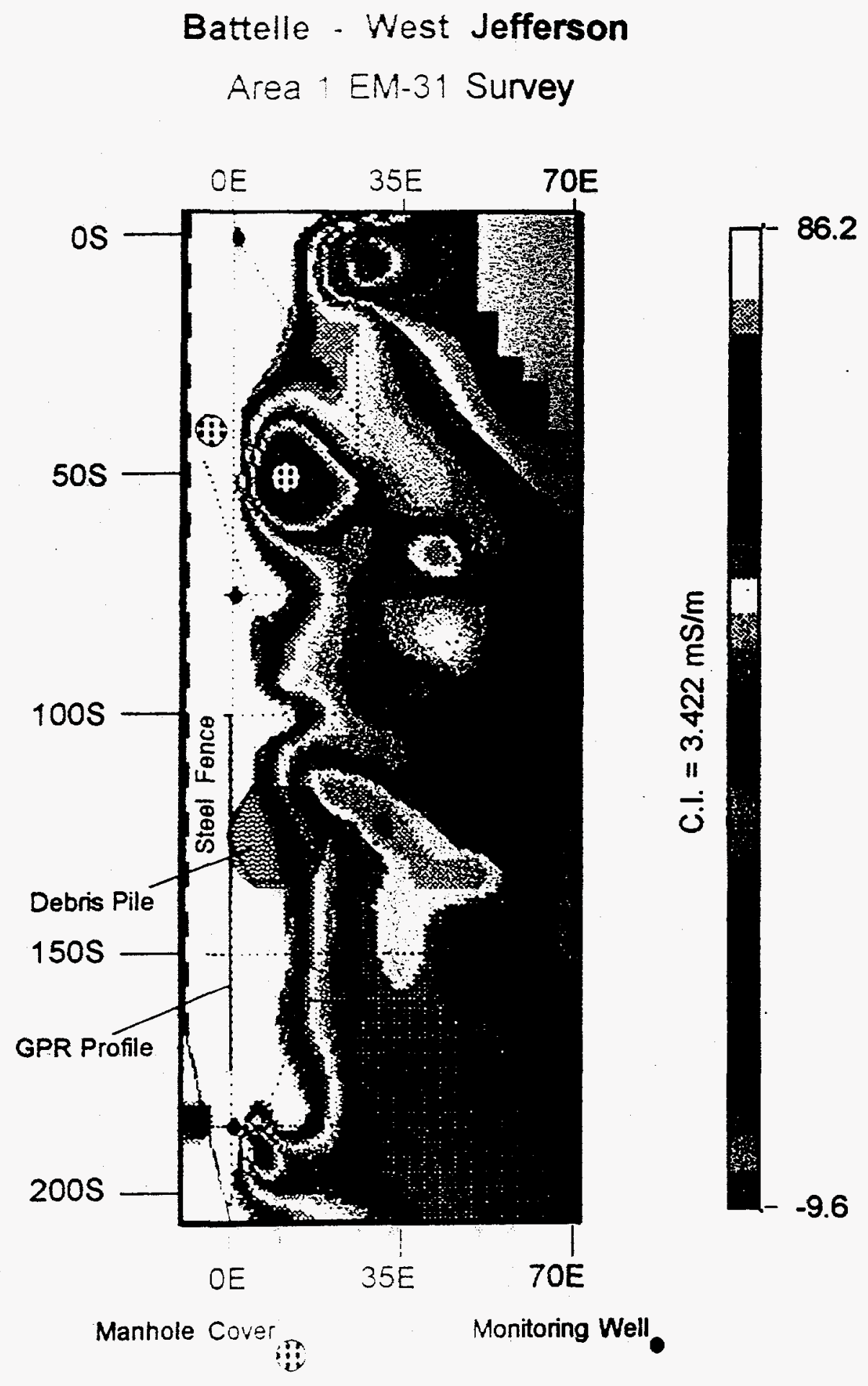

Figure D.2. 


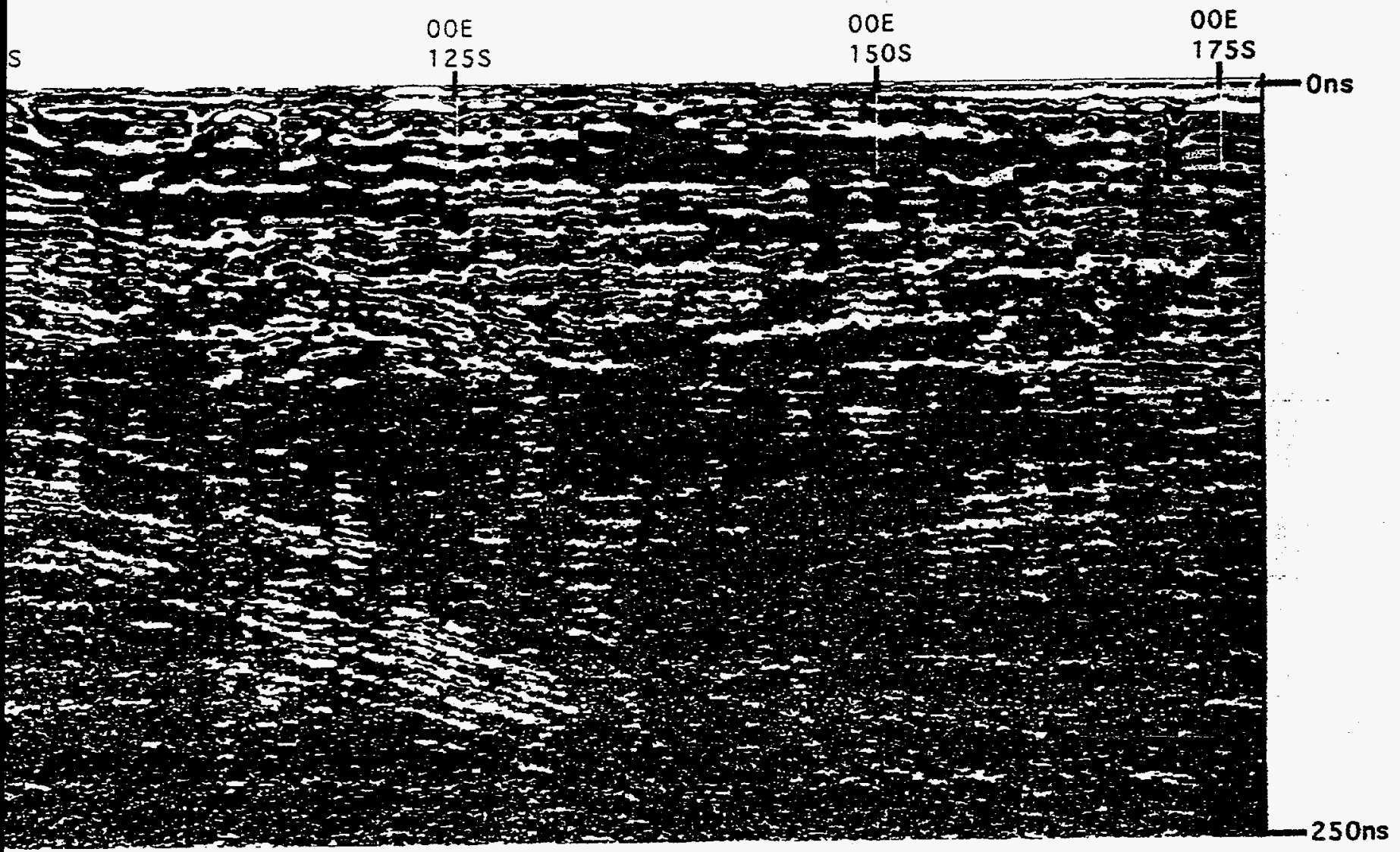

Figure 0.3. 


\section{APPENDIX E:}

ANALYTICAL CHEMISTRY RESULTS AT BATTELLE WEST JEFFERSON 


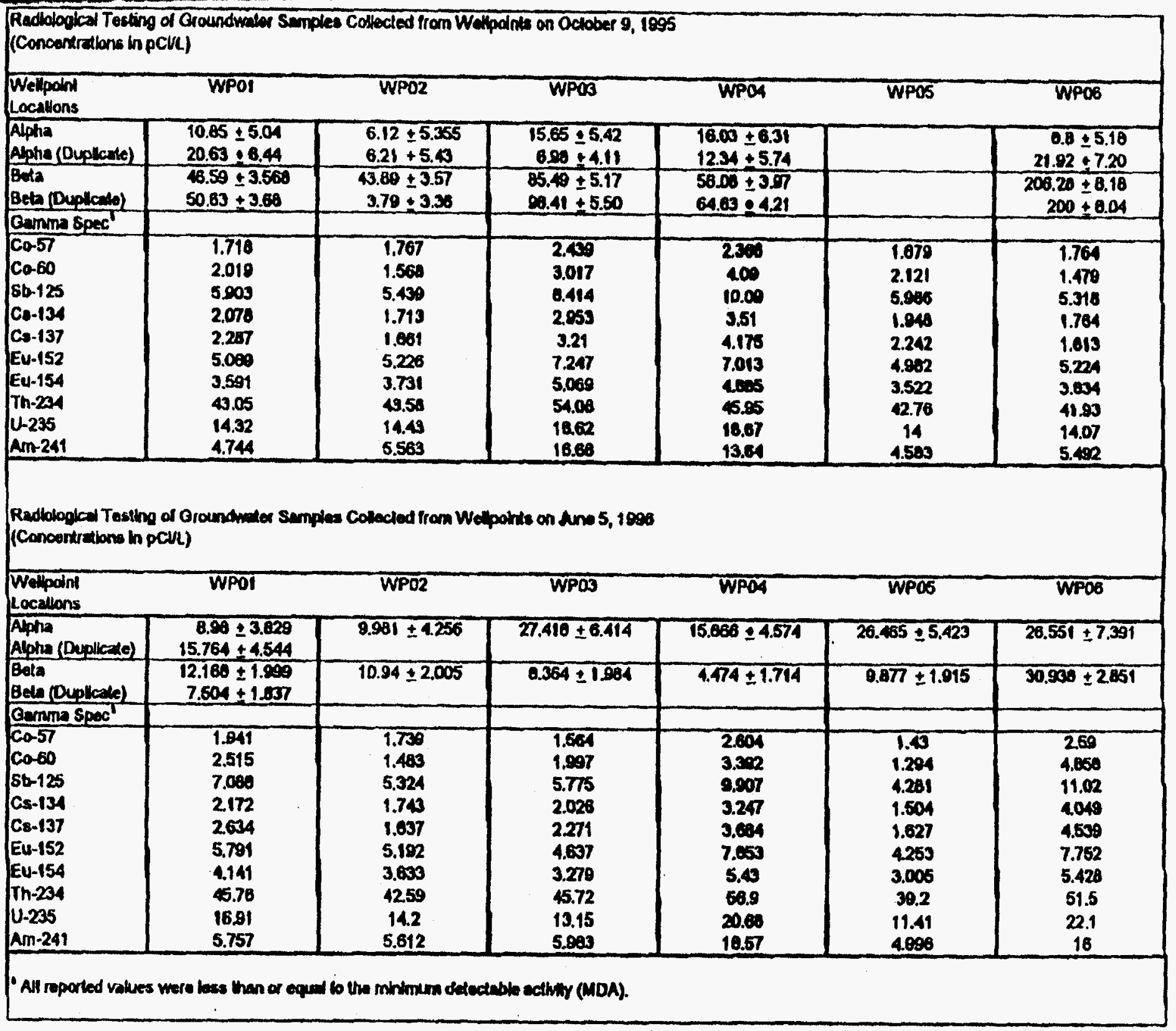

